This report was prepared as an account of work sponsored by an agency of the United States Government. Neither the United States Government nor any agency thereof, nor any of their employees, makes any warranty, express or implied, or assumes any legal liability or responsibility for the accuracy, completeness, or usefulness of any information, apparatus, product, or process disclosed, or represents that its use would not infringe privately owned rights. Reference herein to any specific commercial product, process, or service by trade name, trademark, manufacturer, or otherwise does not necessarily constitute or imply its endorsement, recommendation, or favoring by the United States Government or any agency thereof. The views and opinions of authors expressed herein do not necessarily state or reflect those of the United States Government or any agency thereof.

UAG-R--310

DE88 006849

\title{
STRATIGRAPHY, PETROLOGY, AND GEOCHEMISTRY OF THE SPURR VOLCANIC COMPLEX, EASTERN ALEUTIAN ARC, ALASKA.
}

\author{
by \\ Christopher J. Nye \\ Geophysical Institute \\ University of Alaska Fairbanks \\ Fairbanks, Alaska, 99775
}

(with an appendix describing geothermal fuid chemistry by Roman J. Motyka and Christoper J. Nye)

Submitted to the Alaska Division of Geological and Geophysical Surveys
RSA no. 1070055

December, 1987

Geophysical Institute Report UAG R-310 


\section{DISCLAIMER}

This report was prepared as an account of work sponsored by an agency of the United States Government. Neither the United States Government nor any agency Thereof, nor any of their employees, makes any warranty, express or implied, or assumes any legal liability or responsibility for the accuracy, completeness, or usefulness of any information, apparatus, product, or process disclosed, or represents that its use would not infringe privately owned rights. Reference herein to any specific commercial product, process, or service by trade name, trademark, manufacturer, or otherwise does not necessarily constitute or imply its endorsement, recommendation, or favoring by the United States Government or any agency thereof. The views and opinions of authors expressed herein do not necessarily state or reflect those of the United States Government or any agency thereof. 


\section{DISCLAIMER}

Portions of this document may be illegible in electronic image products. Images are produced from the best available original document. 


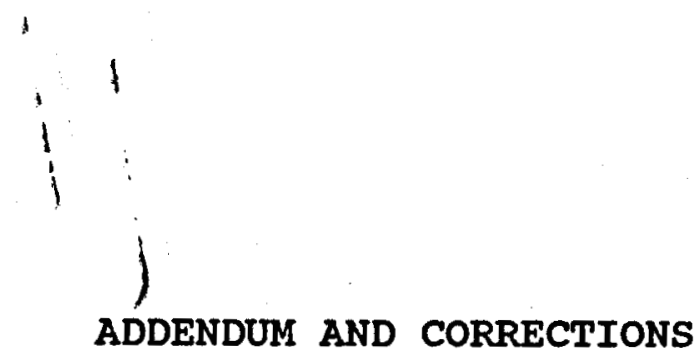

UAG $\mathbf{R}-311$

stratigraphy, Petrology, and Geochemistry of the spurr Volcanic Complex, Eastern Aleutian Arc, Alaska

\author{
Christopher J. Nye \\ Geophysical Institute \\ University of Alaska Fairbanks
}

(with an appendix describing geothermal fluid chemistry by Roman J. Motyka and Christopher J. Nye)

The following disclaimer applies:

\begin{abstract}
This report was prepared as an account of work sponsored in part by an agency of the United States Government. Nelther the United States Government nor any agency thereof, nor any of their employees, makes any warranty, express or implied, or assumes any legal liability or responsibility for the accuracy, completeness, or usefulness of any information, apparatus, product, or process disclosed, or represents that its use would not infringe privately owned rights. Reference herein to any specific commercial product, process, or service by trade name, trademark, manufacturer, or otherwise, does not necessarily constitute or Imply its endorsement, recommendation or favoring by the United States government or any agency thereof. The views and opinions of authors expressed herein do not necessarily state or reflect those of the United States Government or any agency thereof.
\end{abstract}

P. 3, para. 1. "U.S. Department of Energy Grant DE-FG07-84ID2471" should read "U.S. Department of Energy Grant DEFG07-84-ID12524"

P. 60, para. 2. "U.S. Department of Energy Grant DE-FG0784-ID12471" should read "U.S. Department of Energy Grant DEFG07-84-ID12524"

Some copies of the report were distributed as UAG $R-310$. The correct Geophysical Institute report number is UAG R311. 


\section{TABIE OF CONTENTS}

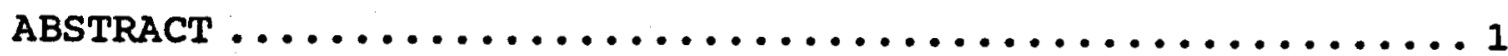

INTRODUCTION .............................

TECTONIC AND GEOLOGIC SETTING ................. 5

STRATIGRAPHY AND GEOLOGY .................... 8

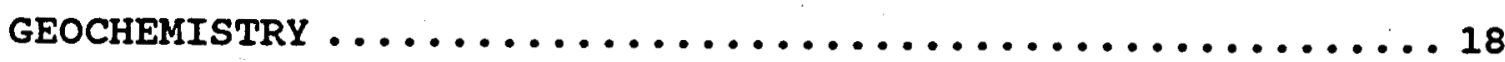

Major Elements ......................... 18

Trace Elements ........................... 25

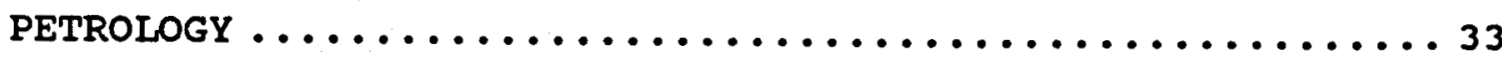

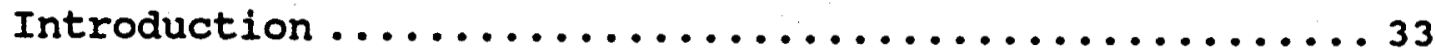

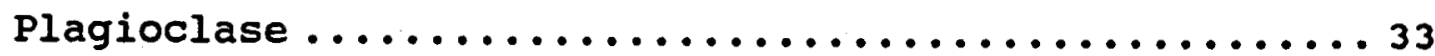

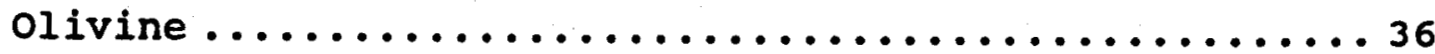

Clinopyroxene ..........................40

Orthopyroxene ............................44

Amphibole ............................... . . . . . . .

Spinel ................................ 51

Crystal clots ............................ 53

SYNTHESIS AND INTERPRETATION .................. 55

IMPLICATIONS FOR GEOTHERMAL RESOURCES ............. 58

ACKNOWLEDGEMENTS ........................... 60

REFERENCES ...........................61

APPENDIX I - Whole rock geochemsitry and point count data 68 APPENDIX II - summary of mineral compositions . . . . . . 74 APPENDIX III - Plagioclase compositions ...........81 APPENDIX IV - Olivine compositions ..............93 APPENDIX $v$ - Clinopyroxene compositions ...........98 APPENDIX VI - orthopyroxene compositions .......... 108 APPENDIX VII - Hornblende compositions ........... 117 APPENDIX VIII - spinel compositions ............. 120 APPENDIX IX - Chemistry of geothermal fluids ........ 122 


\section{LIST OF FIGURES}

Figure 1. Location map. $\ldots \ldots \ldots \ldots \ldots \ldots \ldots \ldots \ldots$

Figure 2. Generalized geologic map. ...............9

Figure 3. Stratigraphic variation of SiO2, K2O

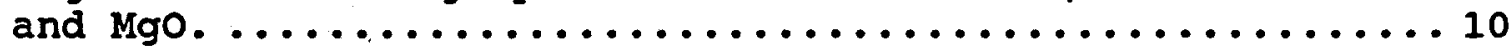

Figure 4. Major element variation diagrams.......... 14

Figure 5. Paths of least-squares fractionation

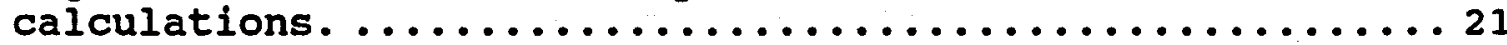

Figure 6. Ternary plots of normative PL, DI, OL,

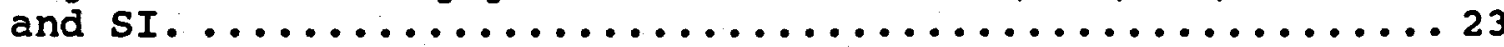

Figure 7. Trace element variation diagrams.........26

Figure 8. Trace element fractional

crystallization models. ...................... 29

Figure 9. $\mathrm{Ca} /(\mathrm{Ca}+\mathrm{Na})$ of plagioclase vs, whole-

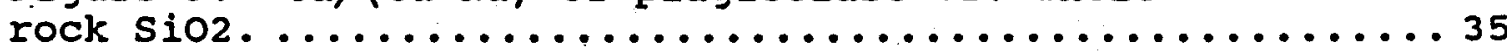

Figure 10. Change in calculated plagioclase

composition with fractional crystallization of SVC

andesite and basalt. .......................... 37

Figure 11. Olivine Mg\# vs. Feot/Mgo of the

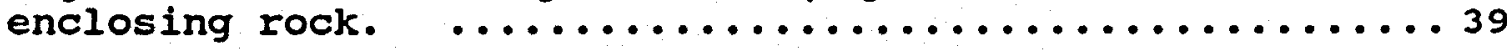

Figure 12. Clinopyroxene Mg\# vs Feot/Mgo of the

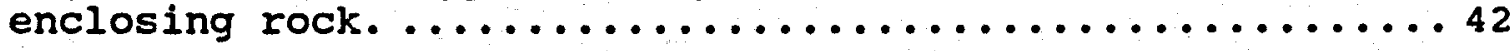

Figure 13. Effect of olivine and pyroxene

addition and magnetite subtraction on Feot/Mgo........45

Figure 14. Orthopyroxene Mg\# vs Feot/Mgo of the

enclosing rock. .........................47

Figure 15. AlIV vs. Na+k for SVC hornblendes........49

Figure 16. $\mathrm{Cr} /(\mathrm{Cr}+\mathrm{Al}), \mathrm{YAI}$, and $\mathrm{YFe}$ vs. Mg\# for

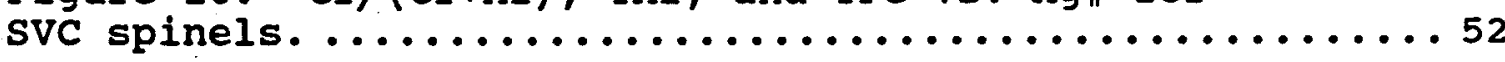




\section{LIST OF TABLES}

Table 1. Results of least-squares fractional

crystalization calculations..................... 20

Table 2. Distribution coefficients...............28

Table 3. Potential crustal contaminants............ 31 


\section{ABSTRACT}

The Spurr Volcanic complex (SVC) is a calcalkaline, medium$K$, sequence of andesites erupted over the last quarter of a million years by the easternmost currently active volcanic center in the Aleutian Arc. The ancestral Mt. Spurr was built mostly of andesites of uniform composition (58-60\% $\left.\mathrm{SiO}_{2}\right)$, although andesite production was episodically interrupted by the introduction of new batches of more mafic magma. Near the end of the pleistocene the ancestral Mt. Spurr underwent Bezymianny-type avalanche caldera formation, resulting in the production of a volcanic debris avalanche with overlying ashflows. Immediately afterward, a large dome (the present Mt. Spurr) was emplaced in the caldera. Both the ashflows and dome are made of acid andesite more silicic than any analyzed lavas from the ancestral Mt. Spurr $\left(60-63 \% \mathrm{SiO}_{2}\right)$, yet contain olivine and amphibole xenocrysts derived from more mafic magma. The mafic magma (53-57\% $\left.\mathrm{SiO}_{2}\right)$ erupted during and after dome emplacement, forming proto-crater Peak and crater Peak. Hybrid pyroclastic flows and lavas were also produced. Protocrater Peak underwent glacial dissection prior to the formation of crater Peak in approximately the same location. The vents for the silicic and mafic lavas are in the center and in the breach of the 5 by $6 \mathrm{~km}$ horseshoe shaped caldera, respectively, and are less than $4 \mathrm{~km}$ apart. Late Holocene eruptive activity is restricted to crater Peak, and magmas continue to be relatively mafic and derived from deep within the crust.

SVC lavas are plag \pm ol $+\mathrm{cpx} \pm$ opx + mt bearing. All post-caldera units contain small amounts of high $\mathrm{Al}_{2} \mathrm{O}_{3}$, high alkali pargasite, and Proto-Crater Peak and crater Peak lavas contain abundant pyroxenite and anorthosite clots presumably derived from an immediately pre-existing magma chamber. Ranges of mineral chemistries within individual samples are 
often nearly as large as ranges of mineral chemistries throughout the svc suite, suggesting that magma mixing is common.

SvC lavas are unlike experimentally produced cotectic liquids and are thus unlikely to be related to each other by fractional crystallization. Magmatic evolution must instead be controlled in large part by crustal assimilation. Flat Y$\mathrm{SiO}_{2}$ and $\mathrm{Nb} \mathrm{SiO}_{2}$ trends and $\mathrm{Rb}$ enrichment beyond that which can be reasonably modeled by fractional crystallization also suggest extensive assimilation of lower crust, bulk upper crust, or partial melts of local batholithic material.

Since at least the mid-Holocene there has been no shallow, silicic magma chamber at the svC. This increases the expectation that the low resistivity layer described by Turner and Wescott (1986) is a highly conductive layer of bedrock, such as a thick, altered tuff. 


\section{INTRODUCTION}

The Spurr Volcanic Complex (SVC) comprises an ancestral andesitic stratovolcano, a debris avalanche deposit, and two post-caldera domes or cones with associated pyroclastic deposits and represents continuous volcanic activity over at least the last 250,000 years. The SVC is located 130 miles west of Anchorage, Alaska's biggest population center (Figure 1), and only $65 \mathrm{~km}$ from the nearest electrical transmission line. In part because of it's proximity to a major energy market the Geophysical Institute of the University of Alaska Fairbanks and the Alaska Division of Geological and Geophysical surveys undertook a thorough, multifaceted, study of the geothermal potential of the sVC area. Much of the funding for this study was provided by the U.S. Department of Energy Grant DE-FG07-84-ID2471.

The results of geophysical studies, soil He and Hg surveys, and $\mathrm{K}$-Ar geochronology were reported by Turner and wescott (1986). They found controlled source audio-magnetotelluric evidence of a discontinuous subhorizontal zone of anomalously low resistivity which underlies much of the southern flank of the SVC at about sea level. This zone is coincident with soil $\mathrm{Hg}$ and He anomalies and self-potential anomalies. Turner and Wescott (1986) interpreted the coincidence of geophysical and geochemical anomalies as strong evidence of the presence of a geothermal reservoir at depth.

Turner and Wescott (1986) also presented an abbreviated account of the geology of the svc. This study presents an expanded treatment of SVC geology. In addition, this study presents whole-rock and mineral chemical data from all volcanic units within the SVC and analyses and interpretation of the geochemistry of waters from a hot spring on the southern flank of Crater Peak and gases from fumaroles near 


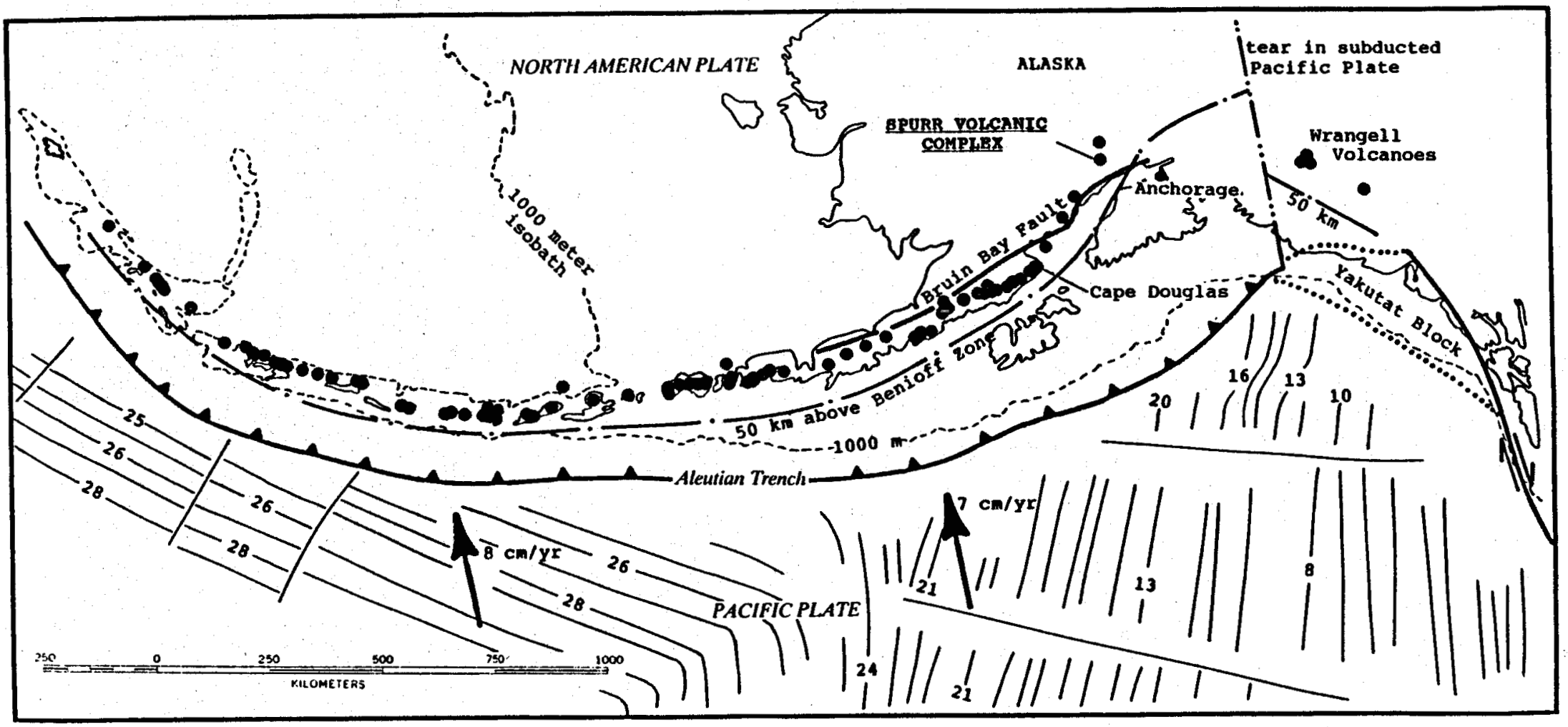

Figure 1. Location of the Spurr Volcanic Complex, other Aleutian volcanic centers, and various tectonic, geographic, and geologic features of the Aleutian Arc. From Kienle et al. (1983), Jacob et al. (1977), stephens et al. (1984), and the circum-Pacific council for Energy and Mineral Resources (1981a, 1981b). 
the summit of crater Peak. The whole-rock and mineral geochemistry is interpreted in terms of the nature and history of the magmatic plumbing system which has been feeding magma to the surface. Data presented herein represent the first available geochemical data from the svc.

\section{TECTONIC AND GEOLOGIC BETTING}

The Aleutian arc is forming in response to subduction of the Kula and Pacific Plates beneath the North American Plate. At present subduction is nearly orthogonal for the central $2000 \mathrm{~km}$ of the arc (Jacob et al., 1977, Figure 1). The arctrench gap progressively widens from about $200 \mathrm{~km}$ in the central Aleutians to about $500 \mathrm{~km}$ at the svC. East of Cape Douglas (in the easternmost $265 \mathrm{~km}$ of the arc) the angle between the convergence vector and the volcanic front increases abruptly from 102 to 137 degrees. The angle between the convergence vector and depth contours on the Benioff zone, however, increases gradually in the eastern arc (Kienle et al., 1983). The eastward increase of the arc-trench gap is accompanied by a widening of the shallowly dipping upper portion of the subducted slab. Thus, the distance between the trench and the $50 \mathrm{~km}$ depth contour increases while the distance between the $50 \mathrm{~km}$ depth contour and the volcanic front remains fairly constant. Jacob et al. (1977) attribute the widening of the arc-trench gap to eastward-increasing amounts of offscraped material, and suggest that the offscraping has pushed the eastern portion of the trench progressively southward. Alternatively, von Huene et al. (1985) suggest that the shallowly dipping portion of the slab may reflect the subduction of a hypothetical westward extension of the Yakutat Block, which they expect to be buoyant. The von Huene et al. hypothesis, if correct, would not affect magma-genetic processes beneath the arc, because the proposed subducted portion of the Yakutat Block cannot yet have reached deep enough to be involved in magma-genesis. 
The SVC is the easternmost active center of the arc, but one more center, Hayes Volcano, lies $40 \mathrm{~km}$ to the northnorthwest along the arc. Benioff zone seismicity, however, continues some $400 \mathrm{~km}$ to the northwest, where it terminates abruptly along a line parallel to the Pacific - North America convergence vector originating in easternmost Prince william Sound (Figure 1). The abrupt decrease in seismicity marks a tear in the Pacific Plate. The Wrangell volcanoes lie east of this tear, above a weakly defined Benioff zone inboard of the Yakutat Block (stephens et al., 1984). The reason for the lack of Recent volcanism between the SVC and the Wrangells is unknown, although there are three possible contributing factors. First, P-wave travel-times obtained during the Amchitka nuclear tests outline an anomalously slow zone beneath the cook Inlet and western Alaska Peninsula volcanoes (Biswas, 1973). If this is an expression of a low-Q zone (which appears to be a prerequisite for arc volcanism, Gill, 1981), then the termination of this zone just northeast of the SVC may provide a reason for (but not a cause of), the lack of volcanism to the east. second, the svc is west and south of the zone of large negative bouger anomalies of the central Alaska Range (up to -120 milligals; Barnes 1977a, 1977b). These gravity anomalies presumably reflect the thick root of the Alaska Range, and suggest that the crust is sufficiently thick in this region that no asthenospheric mantle can penetrate high enough to participate in magma production. This is the preferred explanation of cross and Pilger (1982). Third, the arc-trench gap east of the svC may be wide enough that the subducted slab dewaters to such an extent that it can not participate in magma genesis at depth. This explanation rests on the supposition that slab dehydration is required for the production of arc magmas, a point which is not universally agreed on.

oceanic crust of the Pacific plate is currently being subducted throughout the arc. Magnetic lineations are 
presently subparallel to the trench in the western $85 \%$ of the arc. As recently as about $10 \mathrm{Ma}$, magnetic lineations were parallel to the trench throughout the arc (Engebretson et al., 1985). The age of the Pacific Plate at the trench is about 60 m.y., and becomes younger downdip. Extrapolating from the information about the Kula-Pacific-Farallon spreading rates preserved in magnetic lineations on the Pacific Plate today, the plate is about $56 \mathrm{~m} . \mathrm{y}$. old beneath the volcanic front. The subducted Kula Ridge is expected to be at least $600 \mathrm{~km}$ downdip (Engebretson et al., 1985).

The SVC is built on the continental crust of southern Alaska, which was formed by Mesozoic amalgamation and late Mesozoic or early Tertiary accretion of many independently formed terranes (see Panuska and stone, 1985 and coe et al., 1985, for reviews.) The terrane which underlies the eastern arc is the Peninsular terrane of Jones et al. (1981), which has been redefined (and renamed the Alaska Peninsula Terrane) by wilson et al. (1985). The portion of the Alaska Peninsula Terrane which underlies the svc area consists of silurian through Early Jurassic limestone, basalt and clastic rocks, and Jurassic and/or cretaceous flysch, all of which are intruded by the Jurassic, early Tertiary, and mid-Tertiary rocks of the Alaska-Aleutian Range batholith. Most sedimentary rocks are greenschist facies or below, but can be higher near contacts with plutons (wilson et al., 1985).

The basement of the sVC is dominantly intrusive. Immediately east of the summit of Mt. Spurr the volcanics overlie migmatite and quartz monzonite which are approximately $57 \mathrm{~m} . \mathrm{y}$. old (Reed and Lanphere, 1972; Magoon et al., 1976). The volcanics abut this same unit west of Mt. Spurr. Immediately south of the Chakachatna River bedrock consists of two granodiorite units approximately 62 and $69 \mathrm{my}$ old (Reed and Lanphere, 1972; Magoon et al., 1976). Conglomerate, sandstone, siltstone and ashflow tuff of the west Foreland Formation is faulted against the quartz monzonite just east of 
Straight creek, and underlies the SVC volcanics west of straight creek. The quartz monzonite intrudes the Juracretaceous flysch $15 \mathrm{~km}$ to the NNE.

\section{BTRATIGRAPHY AND GEOLOGY}

There are six main stratigraphic units within the spurr Volcanic Complex (SVC) (Figure 2): the ancestral Mt. Spurr, Mt. Spurr, crater Peak, a composite-pyroclastic fan of uncertain origin, a debris avalanche deposit, and a series of young ash-flow tuffs. A preliminary discussion of these units, expanded herein, is given by Turner et al. (1986). crater Peak is subdivided into two stages, "proto-Crater Peak" and "Crater Peak", which are separated by an erosional interval, which may only represent a temporary glacial overwhelming of essentially continuous Holocene crater Peak volcanism. The ancestral Mt. Spurr was partially destroyed by Bezymianny-type avalanche caldera formation during the Late Wisconsin or Early Holocene, which produced the debris avalanche deposit and overlying ash-flow tuffs. Mt. Spurr is a silicic-andesite dome which grew in the center of the crater, while crater Peak is a basaltic-andesite cone which occupies the breach in the ancestral Mt. Spurr.

Ancestral Mt. spurr. The ancestral Mt. Spurr is the oldest unit of the SVC, and is composed of pyroclastic units and lavas of diverse lithologies. Stratigraphically lower portions of the pile are dominated by pyroclastic units and upper portions are dominated by lava flows. Most of the lava flows are of fairly uniform composition (58-60\% $\left.\mathrm{SiO}_{2}\right)$ but there are individual flows which are substantially more mafic intercalated with the acid andesites (Figure 3 ). There are few flows with compositions between the mafic and felsic flows. Lavas with less than $57 \% \mathrm{SiO}_{2}$ are pl+ol+cpx $\pm \mathrm{mt}$ bearing while lavas with greater than $57 \% \mathrm{siO}_{2}$ are pl+cpx+opx+mt bearing. 


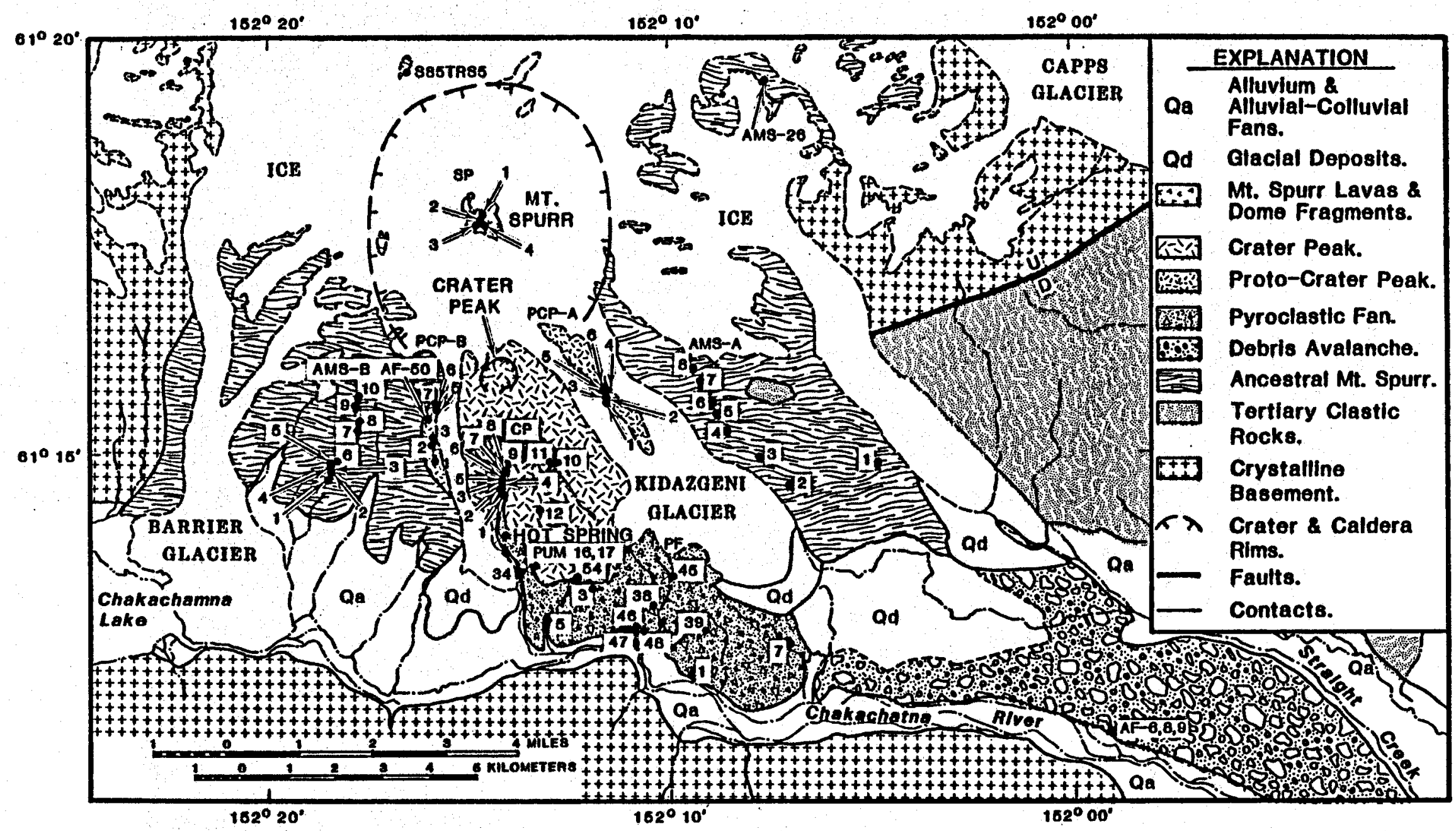

Figure 2. Generalized geologic map of the Mt. Spurr region adapted from Turner and Wescott (1986) and Barnes (1966). Numbers are sample numbers refered to in the text and appendicies. 


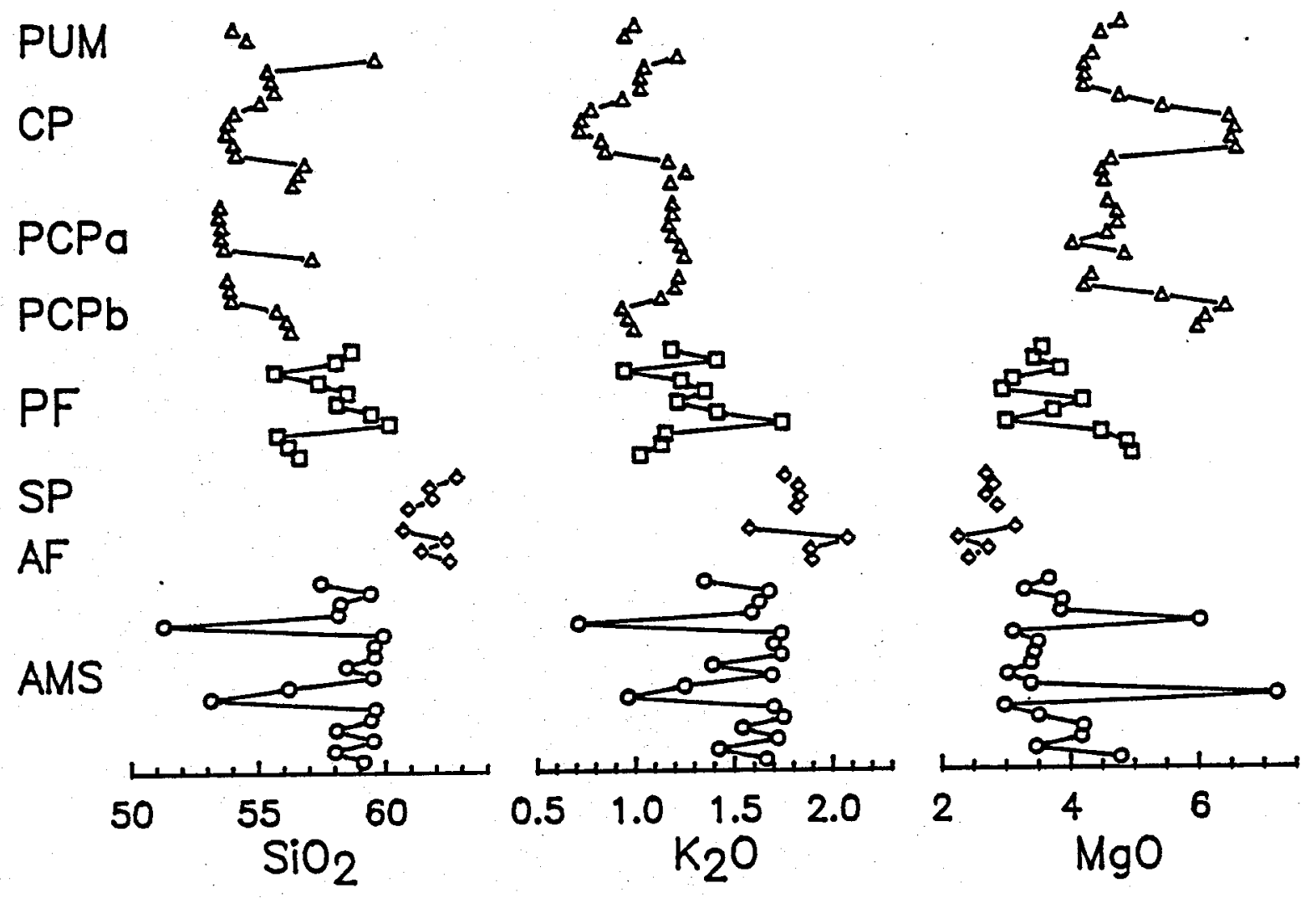

Figure 3. Stratigraphic variation of $\mathrm{SiO}_{2}, \mathrm{~K}_{2} \mathrm{O}$ and $\mathrm{MgO}$ in SVC samples. Abbreviations used are AMS, ancestral Mt. Spurr; AF, ashflows; SP, Mt. Spurr; PF, pyroclastic fan; PCPa, eastern proto-crater Peak; PCPb, western protoCrater Peak; CP, Crater Peak; and PUM, pumice of the 1953 eruption. AMS, PCP, and CP samples are arranged in stratigraphic order. Relative ages of $\mathrm{PCPa}$ and $\mathrm{PCPb}$ are unknown, but they are approximately coeval. SP, PCP, and DP were in part coeruptive. 
The ancestral Mt. Spurr was built during the Late Pleistocene $(>0.255 \pm 0.052 \mathrm{Ma}$ to $<0.058 \pm 0.018 \mathrm{Ma}$, Turner and Nye, 1986, a single older date of $2.08 \pm 0.20 \mathrm{Ma}$ is probably from pre-spurr volcanic bedrock), and was partially destroyed during the production of a debris avalanche. Capps (1929) was the first to recognize the fundamental aspects of the volcanic stratigraphy of the Mt. Spurr region. Juhle and Coulter (1955) however, disagreed with the interpretation that the peaks surrounding Mt. Spurr were a caldera rim and suggested that "the postulated giganitc caldera is only a fortuitous arrangement of discrete mountain peaks of dissimilar origins". Juhle and coulter (1955) mistakenly reported that lavas of the eastern rim of the caldera proposed by capps (1929) dipped radially outward from their respective summits, and that the peaks of the western rim were granitic. In fact, all ice-free peaks on the rim of the proposed caldera are volcanic and are composed of flows which dip radially away. from Mt. Spurr, which is located near the summit of the ancestral Mt. Spurr. Riehle (1985) agreed with Capps (1929) and was the first to recognize the debris avalanche deposits and the mechanism of caldera collapse.

Debris Avalanche. The ancestral Mt. Spurr was partially destroyed by a Bezymianny-type eruption that produced a volcanic debris avalanche which traveled a minimum of $25 \mathrm{~km}$ east of the center of the ancestral Mt. Spurr (Figure 2). The debris avalanche lies between the Chakachatna River and straight creek and is composed of coherent blocks of volcanic material up to at least 100 meters in diameter. These blocks retain their internal volcanic structure but are rotated from their original attitude. Exposures are limited to the banks of the Chakachatna River, but the unit can be recognized elsewhere by the humocky surface typical of debris avalanches. The debris avalanche is not exposed west of the southeast corner of Kidazgeni Glacier (Figure 2). Lack of exposure, uncertainty about the original areal extent of the 
debris avalanche deposit and the extent of its erosion, and uncertainty about the configuration of the surface on which the debris avalanche deposit rests all make it impossible to accurately estimate the volume of the deposit. However, rough geometric estimates of the volume of both the avalanche deposit and the volume of the missing portion of the ancestral Mt. Spurr are in agreement with each other at a few $\mathrm{km}^{3}$.

Ash Flow Tuff. The debris avalanche is overlain by ashflow tuff, which is partially welded and contains well developed fossil fumerole pipes more than $15 \mathrm{~km}$ from the center of the ancestral Mt. Spurr. Riehle (1985) mentioned several ash flows, but no more than one was distinguished in any given outcrop during this investigation. An outcrop in a riverbank exposure $18 \mathrm{~km}$ from the center of the ancestral Mt. spurr is a single high-silica andesite ash-flow several meters thick consisting of pumice blocks as large as $1.5 \mathrm{~m}$ in diameter in a lightly welded to non-welded ashy matrix. The ash flow contains two juvenile lithologies, one very light grey and one dark grey. These are most often present in separate pumice blocks, but occasional bands of the dark pumice a few $\mathrm{cm}$ thick are included in blocks of the light pumice. Both lithologies contain pl+cpx+opx+mt, and the dark lithology contains olivine which is in reaction with the melt. Glass in the dark grey pumice is brown, while glass in the light grey pumice is clear. In spite of the strong contrast in hand specimen and thin section appearance, chemical variation between the two lithologies is slight. AF-08 and AF-09 (Appendix I) are whole rock analyses of the two lithologies from the same outcrop and differ in $\mathrm{sio}_{2}$ by only 1 wt\%. Partial major element analyses of the glasses show that the brown glass is slightly less evolved than the clear glass $\left(\mathrm{SiO}_{2}\right.$, FeOt, and $\mathrm{MgO}$ are $74 \%, 2.1 \%$, and $0.35 \%$, respectively, compared to $76 \%, 1.48$, and $0.17 \%$ ). The ash-flows were most likely erupted during the eruption which generated the debris avalanche and breached the ancestral Mt. Spurr (Riehle, 1985). 
Emplacement of the unusually silicic magma high into the volcanic edifice may have been the trigger which produced caldera formation.

The age of the emplacement of the debris avalanche and the ash-flows is not precisely known. It must be younger than the youngest dated flow on the flanks of the ancestral Mt. Spurr $(0.058 \pm 0.014 \mathrm{Ma}$, Turner and Nye, 1986). The debris avalanche has also not been extensively modified by glaciation and is thus probably younger than the last major ice advance down the Chakachatna River (i.e. Late Wisconsinan, schmoll and Yehle, 1986). As Riehle (1985) has noted, there is no extensive ash-fall layer associated with the ash-flow in the vicinity of the svc. This suggests that the debris avalanche may have formed during a period of extensive ice cover, perhaps in the Late Wisconsinan or Early Holocene.

Mt. spurr. After the partial destruction of the ancestral Mt. Spurr two new vents formed. Mt. Spurr, the most felsic svc vent (Figure 4), grew in the center of the ancestral Mt. spurr, and crater Peak, the most mafic svc vent (Figures 3 and 4), formed in the breach of the old cone. Mt. spurr presently has a summit elevation of $3412 \mathrm{~m}$, and, if the VLF resistivity ice depth measurements of Wescott et al. (1986) are correct, stands $>1000 \mathrm{~m}$ above its base and has a volume, calculated as a simple cone, of approximately $2 \mathrm{~km}^{3}$. Because of extensive ice cover, rock exposure is extremely limited on Mt. spurr. The four samples that were obtained are identical in chemical composition to the ash-flows which overlie the debris avalanche, but differ modally in that none of the four contain olivine, two contain small amounts of hornblende, and one contains rare blotite. The chemical similarity of Mt. Spurr and the ash flows suggests that Mt. Spurr is the dome which formed immediately after collapse of the ancestral Mt. spurr. It is likely that some of the magma which ultimately formed the dome erupted during caldera formation and formed the ashflows which overlie the debris avalanche. Riehle (1985) 

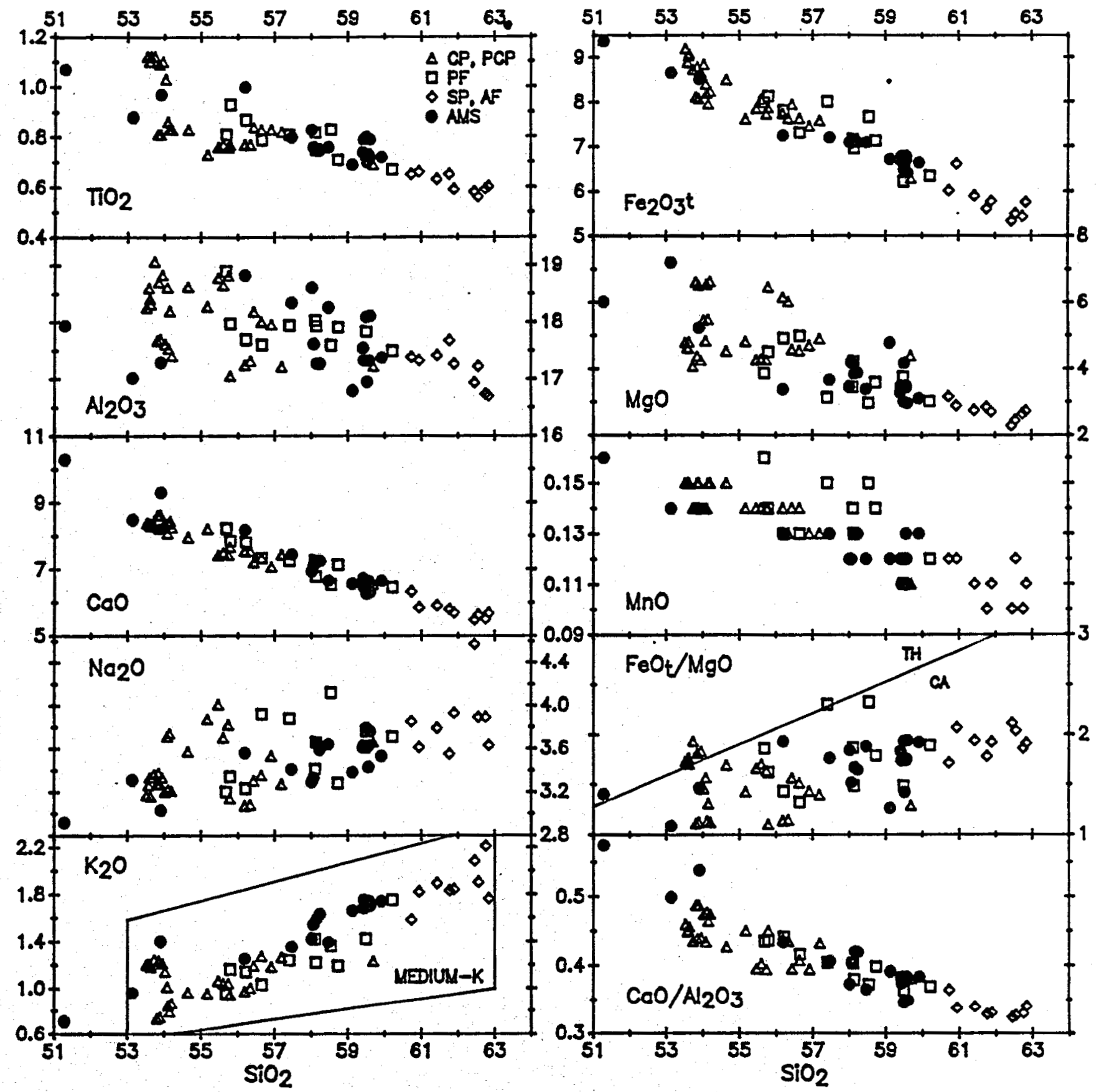

14 
reports a minimum age of older Mt. Spurr tephra of slightly greater than 7000 years, and does not recognize Mt. Spurr tephra younger than 5200 years. While the tephra record indicates that there have been no eruptions of Mt. Spurr in the last 5000 years, the airphoto record shows periods of increased ice melt (and therefore volcanic heat flux) at the summit. During the summer of 1985 there were extensive patches of steaming ground and fields of small fumeroles on the south and southwest flanks of Mt. Spurr, although none exceeded the pressure-boiling point.

crater Peak and proto-crater Peak. The youngest vent, and the site of the 1953 eruption, is crater Peak, which occupies the breach in the ancestral Mt. Spurr. The present summit altitude is $2335 \mathrm{~m}$. Because the topography of the ancestral Mt. Spurr underneath crater Peak is unknown it is impossible to calculate the volume, but geometric constraints suggest that it is about the same as Mt. spurr (ca. $\left.2 \mathrm{~km}^{3}\right)$. Crater Peak was preceded by an earlier cone of similar composition, called proto-Crater peak (Figure 2 ). The two remnants of proto-crater Peak are nested within the breach of the ancestral Mt. Spurr and have flow attitudes which project to a point above the present summit of crater Peak. Proto-Crater Peak was mostly destroyed, presumably by glaciation, and thus must be at least early Holocene. It is not known whether crater Peak and proto-crater Peak represent two discreet cone building phases or just temporary overwhelming of a continuously active vent by glaciers originating in the caldera. A single $k-A r$ age of $0.038 \pm 0.005$ Ma from a protoCrater Peak sample (Turner and Nye, unpub. data) may provide a maximum age. However this sample contains ultramafic and anorthosite xenoliths which are older than the eruption and may carry excess argon, thus the $\mathrm{K}-\mathrm{Ar}$ age may be too old. Riehle (1985) reports a minimum age of basal Crater Peak (including proto-crater Peak) tephra of 6000 years. Thus Mt. 
Spurr and the Crater Peak - proto-Crater Peak complex were, in part, coeruptive.

One of the most unusual aspects of the SVC is that even though Mt. Spurr and proto-Crater Peak were coeruptive; they extruded material of highly contrasting composition. Mt. Spurr erupted the most silicic material from the svc, while proto-crater Peak, simultaneously, erupted the most mafic material (except for a few flows from the ancestral Mt. Spurr, Figure 3).

Lavas from Crater Peak and proto-Crater Peak are of diverse composition and must represent the eruption of several independent batches of magma. For example, at $54 \%$ SiO2, concentrations of $\mathrm{Rb}, \mathrm{MgO}$, and $\mathrm{Ni}$ vary by factors of $3,1.6$, and 4.7, respectively (Figures 4 and 7 ). Crater Peak and proto-crater Peak lavas are also mineralogically complex (Appendix I). Many samples contain three or four of the . possible mafic phases (ol, hb, cpx, and opx), and frequently contain one or more mafic phases in textural or chemical disequilibrium. Proto-Crater Peak, and, to a lesser extent, Crater peak, also contain abundant inclusions of pyroxenite and metamorphic lithologies. clinopyroxenite clots are the most common. These are externally faceted, multigrained clots with straight intragrain contacts. clots are occasionally armored with hornblende crystals. One gabbroic clot containing about $20 \%$ interstitial brown glass contains abundant modal hornblende. Proto-crater Peak and crater Peak lavas have clearly ripped up pieces of a crustal or sub-crustal cummulate body, along with various other debris, on their way to the surface. While selective contamination by this material can explain some of the $\mathrm{Mg}$ and $\mathrm{Ni}$ variation, there is not $\mathrm{a}$ sufficient xenolith volume to explain the variation in $R b$ and other incompatible elements. Mixing with moderate amounts the Mt. Spurr magma may explain the incompatible element variation. 
Crater Peak has undergone a systematic change over that portion of its evolution that can be sampled from the surface. The oldest samples of crater Peak are high in silica and incompatible elements, and low in compatible elements. successively younger samples are increasingly silica- and incompatible element- poor, and $\mathrm{Mg}$ - and $\mathrm{Ni}-\mathrm{rich}$ through sample CP-07, then evolve back toward the composition of the lowermost samples. This cyclic evolution is interrupted by the 1953 eruption, whose products (PUM-16, PUM-17) are slightly more compatible-element rich, and incompatibleelement poor, than immediately previous lavas.

Pyroclastic Fan. There is one other stratigraphic unit which is of uncertain origin. This is a fan of pyroclastic products of diverse composition which lies between the lower flanks of Crater Peak and the upper exposed limit of the debris avalanche deposit (Figure 2). The fan is composed almost completely of juvenile block and ash flows (some of which are palagonitic), which are interbedded with a few lahars, extremely blocky lava flows, and tuffs. The fan contains little of the non-juvenile material from the ancestral Mt. Spurr which characterizes the debris avalanche. Chemical compositions of juvenile blocks within the block and ash flows are variable (Figure 4), but mostly lie between Crater Peak and Mt. Spurr compositions, and have slightly lower concentrations of highly incompatible elements than ancestral Mt. Spurr samples of similar $\mathrm{siO}_{2}$. some samples from this unit contain the pyroxenite clots characteristic of proto-crater Peak lavas.

This unit is overlain by some of the uppermost crater Peak lavas, and is thus probably of Late pleistocene age. The fact that most of the fan lavas are intermediate in composition between Mt. Spurr and crater Peak suggests that the fan may have been formed during the initial stages of emplacement of proto-crater Peak during a period of extensive mixing between the two magma reservoirs that resulted in relatively violent 
eruptions, and thus block and ash flows, rather than lava flows.

\section{GEOCHEMI8TRY}

\section{Yajor Elements}

SVC lavas are medium- $K$ calcalkaline andesites with concentrations of major elements typical of such suites (Figure 4). $\mathrm{TiO}_{2}, \mathrm{Al}_{2} \mathrm{O}_{3}, \mathrm{CaO}, \mathrm{Fe}_{2} \mathrm{O}_{3}, \mathrm{Mgo}$ and $\mathrm{Mno}$ decrease linearly with increasing $\mathrm{SiO}_{2}$, and $\mathrm{Na}_{2} \mathrm{O}$ and $\mathrm{K}_{2} \mathrm{O}$ increase. $\mathrm{Al}_{2} \mathrm{O}_{3}$ and $\mathrm{MgO}$ concentrations are scattered, particularly at low $\mathrm{SiO}_{2}$, presumably reflecting accumulation of small amounts $(<10 \%)$ of plagioclase, pyroxene and olivine. Scatter in the $\mathrm{Na}_{2} \mathrm{O}$ data is mostly due to analytical uncertainty.

The trends of the major element data are compatible with a number of different evolutionary mechanisms, including fractional crystallization, magma mixing, assimilation, or combined assimilation and fractional crystallization (AFC). Major element data are not compatible with an evolutionary mechanism involving only selective crystal accumulation.

Viability of fractional crystallization as an explanation of major element trends can be demonstrated by least squares modeling. In this technique proportions of a presumed parent magma and probable fractionating phases are calculated (to provide a "calculated daughter") such that the calculated daughter composition is as close as possible to the proposed daughter. The sum of the squares of the differences between the proposed daughter and the calculated daughter (hereafter $\mathrm{R}^{2}$ ) is minimized in the calculation, and is the numerical test of how good the model is. In practice $R^{2}$ of less than a few tenths indicates that for most or all major oxides the difference between the calculated daughter and the proposed daughter is within analytical error. 
Results of such least squares calculations using the algorithm of leMaitre (1979) are presented in Table 1. calculations were performed in increments along two different paths through compositional space (Figure 5) for both anhydrous and hydrous mineral assemblages, thus four different crystallization paths are represented in Table $1,1->2 b->7 b->8$ and $3->5 b->8$, each for hornblende-bearing and hornblende-free cases. The samples whose compositions were used are the most phenocryst-poor of the SVC samples ( $\leq 258$ phenocrysts), thus maximizing the likelihood that they represent liquid compositions. The compositions of all silicate phases used in the calculations were derived from linear regressions of each element in each phase against $\mathrm{Mg} \#\left(\mathrm{Mg} / \mathrm{Mg}+\mathrm{Fe}^{2+}\right)$ or An $(\mathrm{Ca} / \mathrm{Ca}+\mathrm{Na})$, and are thus averages, rather than "typical" analyses. (Variables of the equations describing mineral compositions are in Appendix II). Compositions of mafic phases were chosen to be in equilibrium with the average Mg\# of the whole rocks in each step, and the plagioclase composition was chosen to minimize the $\mathrm{CaO}$ and $\mathrm{Al}_{2} \mathrm{O}_{3}$ residuals. Mg\#s of pyroxene, olivine and plagioclase used in the calculations were typical of those found in the rocks. Results are presented for those calculations with lowest $R^{2}$, and, for the hydrous cases, those which maximized the amount of hornblende crystallized.

In all cases the solutions have acceptable $\mathrm{R}^{2}$, and mineral proportions are similar to those observed in the rocks, with the exception that some solutions have anomalously high proportions of orthopyroxene. However, fractionation schemes calculated to reproduce the major element trends are incompatible with the observed trace element variations described below.

Additional information about the petrogenesis of the SVC lavas can be derived by transforming the data into normative plagioclase (PL), diopside (DI), olivine (OL), and silica (SI) and comparing them with other compositions from the literature 
Table 1. Results of least-squares major element modelling

\begin{tabular}{|c|c|c|c|c|c|c|c|c|c|c|c|c|c|}
\hline & & & & HYYOROUS & & & & I & & HYD & ROUS & & \\
\hline Path & 1 & $2 b$ & 7 & $7 b$ & 8 & 3 & 56 & 1 & $2 b$ & $7 b$ & 8 & 3 & $5 b$ \\
\hline Parent & |AMSAO4 & PUN17 & AMSBO8 & MMSAOB & AF50 & AMSBOT & $\mathrm{CPO}$ & |AMSAO4 & PUN17 & AMSA08 & AF50 & AMSB07 & $\mathrm{CPO}$ \\
\hline Par. Si & 51.28 & 54.08 & 56.19 & 57.46 & 60.72 & 53.13 & 56.91 & 51.28 & 54.08 & 57.46 & 60.72 & 53.13 & 56.91 \\
\hline Daught & PU⿴17 & AMSAOB & AF50 & AF50 & SPO4 & CPO3 & AF50 & PUN17 & AMSAOB & AF50 & SP04 & $\mathrm{CPO3}$ & AF50 \\
\hline Dau. $\mathrm{SiO}_{2}$ & 154.08 & 57.46 & 60.72 & 60.72 & 62.84 & 56.91 & 60.72 & 54.08 & 57.46 & 60.72 & 62.84 & 56.91 & 60.72 \\
\hline & 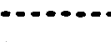 & & 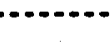 & & & & $\ldots$ & & $*$ & $\cdots$ & & & \\
\hline $\mathrm{SiO}_{2}$ & $1-0.03$ & -0.03 & 0.03 & -0.02 & 0.04 & 0.02 & -0.02 & -0.06 & -0.03 & -0.07 & 0.01 & -0.02 & .0 .04 \\
\hline $\mathrm{O}_{2}$ & -0.06 & 0.03 & -0.17 & -0.02 & -0.03 & 0.05 & -0.07 & 0.00 & 0.05 & 0.08 & 0.05 & 0.22 & -0.03 \\
\hline 0 & $\mid-0.03$ & -0.02 & 0.00 & -0.03 & 0.03 & 0.02 & -0.04 & $\mid-0.08$ & -0.05 & -0.15 & -0.04 & -0.03 & -0.05 \\
\hline $\mathrm{FeO}_{t}$ & $\mid-0.03$ & -0.04 & 0.06 & -0.02 & 0.04 & 0.00 & -0.01 & $\mid-0.07$ & -0.06 & 0.10 & -0.01 & -0.07 & -0.04 \\
\hline Mno & $\mid-0.04$ & -0.03 & -0.04 & -0.03 & -0.02 & -0.03 & -0.03 & -0.03 & -0.02 & -0.02 & -0.01 & -0.01 & -0.02 \\
\hline MgO & -0.02 & -0.04 & -0.01 & -0.01 & 0.01 & 0.00 & -0.02 & $1-0.09$ & -0.06 & -0.06 & -0.06 & -0.04 & -0.03 \\
\hline $\mathrm{CaO}$ & -0.02 & -0.04 & 0.02 & -0.02 & 0.02 & -0.01 & -0.02 & 0.00 & -0.02 & 0.05 & 0.07 & -0.05 & -0.06 \\
\hline $\mathrm{Na}_{2} \mathrm{O}$ & 0.01 & -0.16 & 0.04 & 0.08 & -0.05 & -0.13 & 0.09 & 0.09 & -0.26 & 0.22 & -0.05 & -0.17 & 0.13 \\
\hline $\mathrm{K}_{2} \mathrm{O}$ & 0.04 & -0.04 & -0.06 & -0.10 & -0.13 & -0.16 & -0.09 & 0.05 & 0.02 & -0.04 & -0.06 & -0.12 & -0.06 \\
\hline $\sin R^{2}$ & 0.01 & 0.04 & 0.06 & 0.02 & 0.03 & 0.05 & 0.03 & 0.03 & 0.08 & 0.13 & 0.02 & 0.10 & 0.03 \\
\hline liquid & 0.74 & 0.69 & 0.65 & 0.78 & 0.78 & 0.00 & 0.64 & 0.73 & 0.75 & 0.80 & 0.82 & 0.63 & 0.66 \\
\hline ol & 0.01 & & & & & 0.06 & & & & & & & \\
\hline pl & 0.11 & 0.20 & 0.25 & 0.15 & 0.16 & 0.19 & & 0.10 & 0.14 & 0.11 & 0.11 & 0.11 & 0.22 \\
\hline $\operatorname{cpx}$ & 10.12 & 0.01 & 0.05 & 0.01 & 0.02 & 0.09 & 0.01 & 0.10 & & & & 0.01 & \\
\hline opx & & 0.07 & 0.02 & 0.03 & 0.02 & & 0.08 & 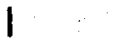 & 0.06 & & & 0.05 & 0.07 \\
\hline hb & & & & & & & & 0.06 & 0.03 & 0.08 & 0.07 & 0.19 & 0.04 \\
\hline$m t$ & 0.02 & 0.03 & 0.03 & 0.02 & 0.01 & 0.03 & 0.03 & 0.02 & 0.02 & 0.01 & 0.00 & 0.00 & 0.02 \\
\hline 0 & 0.04 & & & & & 0.10 & & & & & & & \\
\hline pl & 0.42 & 0.64 & 0.72 & 0.69 & 0.74 & 0.52 & 0.66 & 0.36 & 0.58 & 0.55 & 0.60 & 0.30 & 0.62 \\
\hline cpx & 0.44 & 0.05 & 0.14 & 0.07 & 0.10 & 0.25 & 0.04 & 0.36 & & & & 0.03 & \\
\hline opx & & 0.23 & 0.05 & 0.15 & 0.11 & & 0.23 & & 0.24 & & & 0.14 & 0.21 \\
\hline hb & & & & & & & & 0.21 & 0.11 & 0.39 & 0.40 & 0.52 & 0.11 \\
\hline$n t$ & 0.10 & 0.08 & 0.09 & 0.09 & 0.05 & 0.08 & 0.07 & 0.07 & 0.08 & 0.06 & 0.00 & 0.00 & 0.06 \\
\hline
\end{tabular}




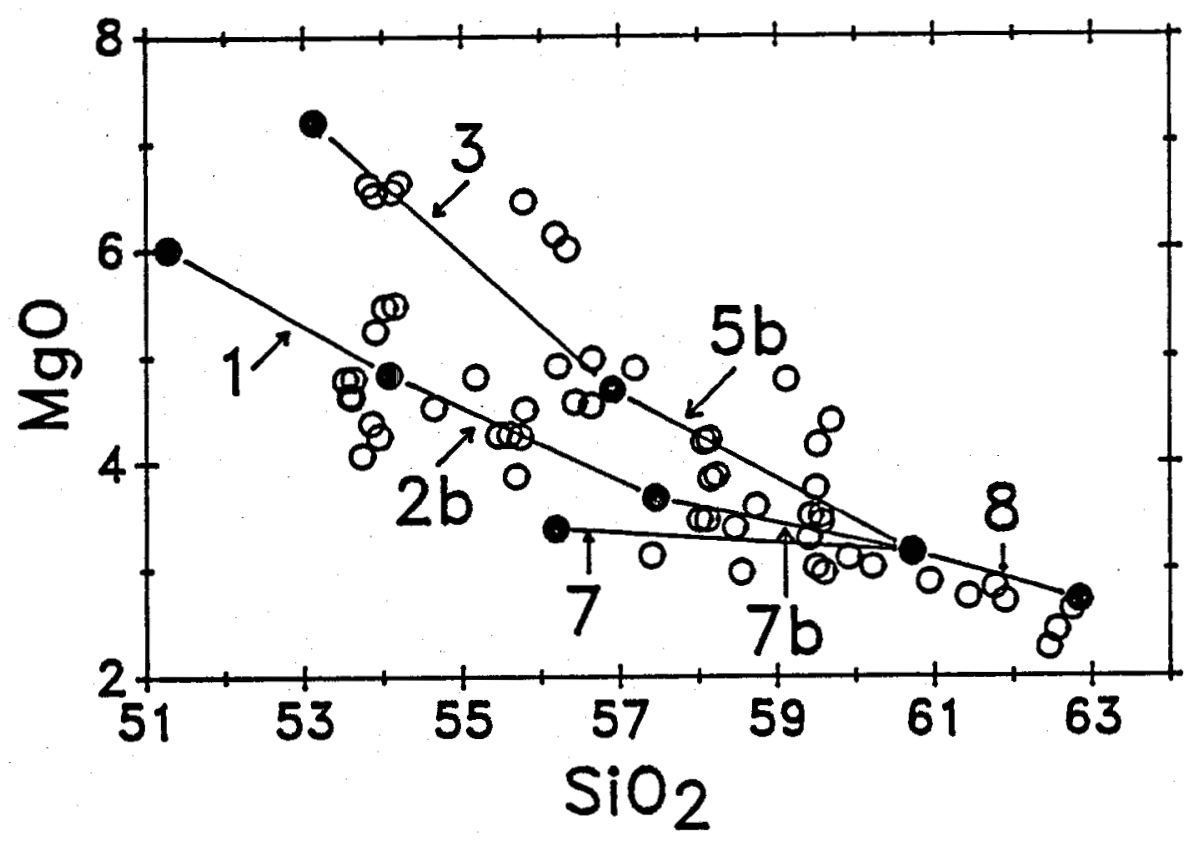

Figure 5. Paths along which least-squares major element calculations were performed. Numbers refer to individual steps in Table 1. 
which were formed under known conditions (Figure 6). SVC lavas fall in a band which is displaced from low to moderate pressure cotectics in both dry and water-undersaturated systems. Thus the SVC lavas cannot be related to each other solely by fractional crystallization of plagioclase, pyroxenes and olivine under conditions similar to those of the experimental runs referred to in Figure 6 . The svc lavas are also a poor match for the high-pressure, multiply-saturated, experimentally produced liquids of Elthon and Scarfe (1984) which plot on the ol side of the MORB cotectic in the projections PL-OL-SI and OL-PL-DI, instead of the PL side, where the SVC lavas plot.

Least squares modeling (Table 1) permits the interpretation that hornblende fractionation played a significant role in the genesis of SVC lavas. This possibility can be tested by comparing the relative positions of SVC data and experimental liquids known to be in equilibrium with hornblende. Such liquids from Helz (1976) are plotted in Figure 6. The higher SI and PL and lower DI and oL of hornblende equilibrated liquids compared to SVC lavas suggest that a petrogenetic model involving fractional crystallization of a hornblendegabbro assemblage from a basaltic parent is not appropriate at Spurr.

Because the SVC lavas fall off experimentally determined cotectics, fractional crystallization cannot be a dominant process relating the lavas. The systematics of SVC lavas in PL-OL-DI-SI compositional space is very much like that of the Medicine Lake volcano lavas discussed by Grove et al. (1982). As discussed by Grove et al., the systematics suggest that crustal assimllation and/or magma mixing can be important petrogenetic processes.

Mafic SVC lavas are displaced from the low pressure MORB cotectic in the same direction as the evolved lavas, and are also displaced from compositions which are thought to be 


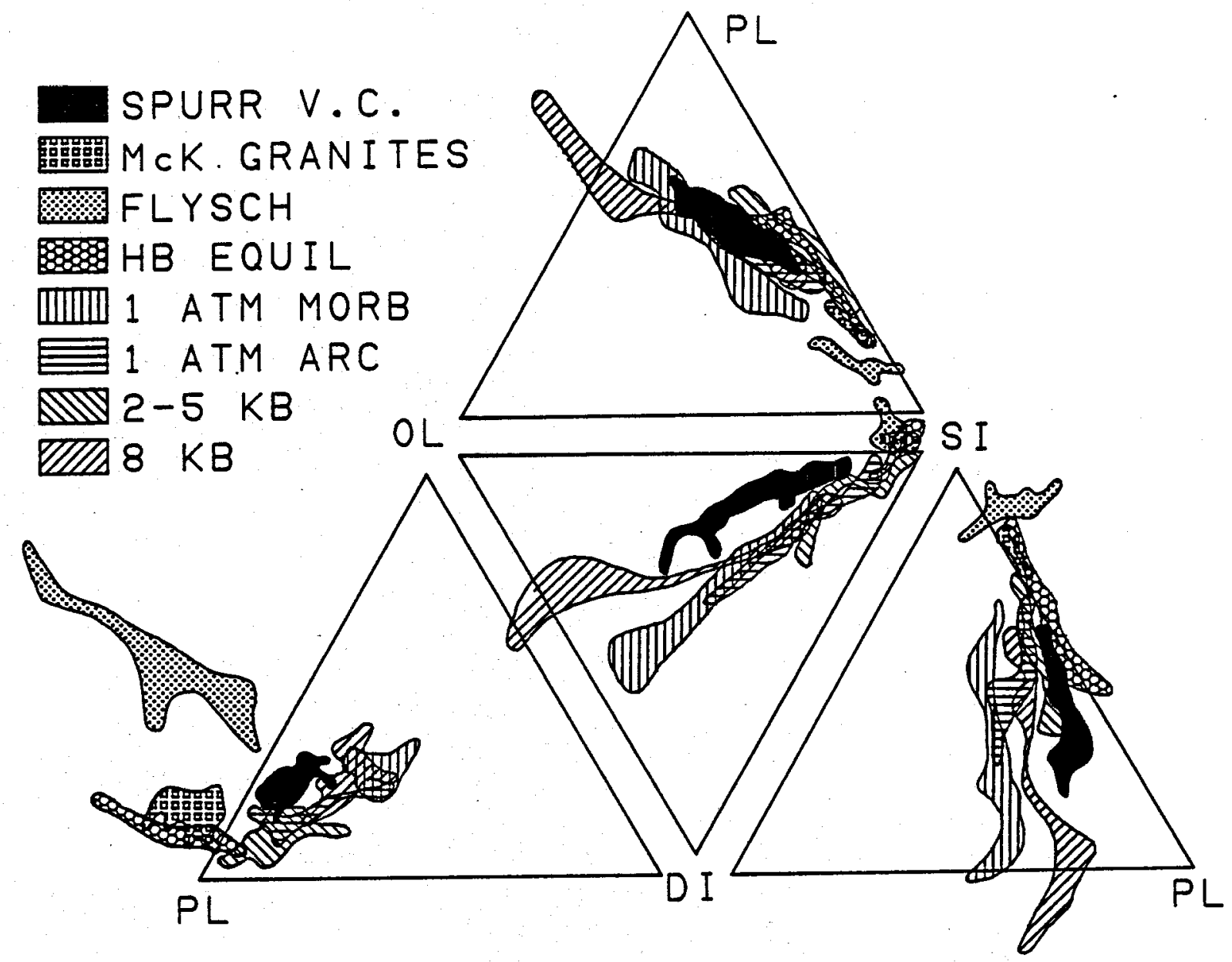

Figure 6. Four projections in the tetrahedron PL-DI-OL-SI. Normative components were calculated by the method of Grove et al. (1982).. One atmosphere MORB (pl+ol+cpx) and arc (2 px) cotectics are from Grove et al. (1982), Grove and Bryan (1983), Walker et al. (1979), and Baker and Eggler (1987). 2-5 Kbar (water undersaturated) and 8 Kbar (dry) cotectics are from Baker and Eggler (1987). Compositions of liquids equilibrated with hornblende are from Helz (1976). Analyses of McKinley sequence granites and Jura-Cretaceous flysch, from about $150 \mathrm{~km}$ north of the sVc, are from Lanphere and Reed (1985). 
mantle-derived primary arc magmas by Kay et al. (1982) and Nye and Reid (1986) (Figure 6). As examples, when projected from OL, the proposed mantle-derived compositions of Kay et al. (1982) and Nye and Reid (1986) fall on the MORB array, while even the most mafic SVC lavas are displaced towards PL. When projected from DI all SVC lavas fall on the PL side of the MORB array, while mantle derived compositions fall on the or side.

The most mafic SVC lavas are strikingly similar to high-Al parental compositions which, based on experimental phase equilibria, Johnston (1986) and Baker and Eggler (1983, 1987) claim are not related to mantle-derived melts by olivine dominated fractional crystallization, but are primary partial melts of the subducted slab. Evidence for these assertions is the large field of plagioclase-only at the liquidus (which requires that low-pressure olivine fractionation can not have been important in the past history of these magmas), and the fact that they are multiply saturated with clinopyroxene and garnet at high pressure (and thus can be melts of an eclogitic source). Marsh (1982 and previous papers), Myers et al. (1985, 1986), Brophy (1986) and Brophy and Marsh (1986) also advocate origin of parental Aleutian magmas by partial melting of the subducted slab.

There is, however, an alternative to fusing the slab to produce the most mafic SVC lavas and the starting materials of Johnston (1986) and Baker and Eggler (1983, 1987). Leastsquares calculations show that removal of a plagioclase-poor mineral assemblage can drive mantle-derived primary arc magmas such as OK4 (Kay et al. 1982) to compositions similar to those which have a large interval of plagioclase crystallization on the liquidus (e.g. Kay et al. 1982; Conrad and Kay, 1984; Brophy, 1986; Gust and Perfit, 1987). Green and Ringwood (1967) have crystallized such an assemblage from a basalt at 9 $\mathrm{kb}$, and state that the liquid produced by crystallization of such an assemblage may have only plagioclase on the liquidus 
at low pressure. Gust and Perfit (1987) have also experimentally produced high-Al basalt from a high-Mg, mantlederived basalt by moderate pressure crystallization of olivine and pyroxene. Kay et al. (1982) have previously appealed to high pressure clinopyroxene dominated crystallization to produce calcalkaline rocks from a mantle derived primary magma. A process of moderate-pressure fractionation of a plagioclase-poor assemblage may thus be able to produce the mafic SVC lavas, although the apparent conflict of this conclusion with the phase equilibria of high-Al basalt has yet to be resolved.

\section{Trace Elements}

Concentrations of $\mathrm{Rb}, \mathrm{Zr}, \mathrm{Y}, \mathrm{Nb}, \mathrm{Sr}$, and $\mathrm{Nl}$ have been determined for all SVC samples (Appendix $I$ ). In addition this discussion will treat $\mathrm{K}$ as a trace element, since it is not an essential structural constituent of any precipitating phase. $\mathrm{Rb}, \mathrm{K}$ and $\mathrm{Zr}$ increase linearly with increasing $\mathrm{SiO}_{2}$ and $\mathrm{Y}$ and $\mathrm{Nb}$ remain constant (Figure 7 ). Sr and $\mathrm{Ni}$ are scattered, but decrease with increasing $\mathrm{SiO}_{2}$ (Figure 7 ). All trace elements are scattered about their trends by amounts well in excess of analytical error. This scatter is especially evident in mafic lavas from crater Peak and proto-crater Peak, where, for example, $\mathrm{Rb}$ varies by more than a factor of 3 at constant $\mathrm{SiO}_{2}$. A few mafic ancestral Mt. Spurr lavas are also anomalously enriched in highly incompatible elements, and fall off the average trend of SVC lavas. Ancestral Mt. Spurr lavas are slightly higher in incompatible elements; and slightly lower in compatible elements, than other svc lavas, although major element trends overlap with those of crater Peak, Mt. spurr and the pyroclastic fan, which permits the interpretation that a major discontinuity in magma supply or plumbing geometry developed just prior to caldera formation.

Numerical models of fractional crystallization have been constructed using the Raleigh fractionation equation, 

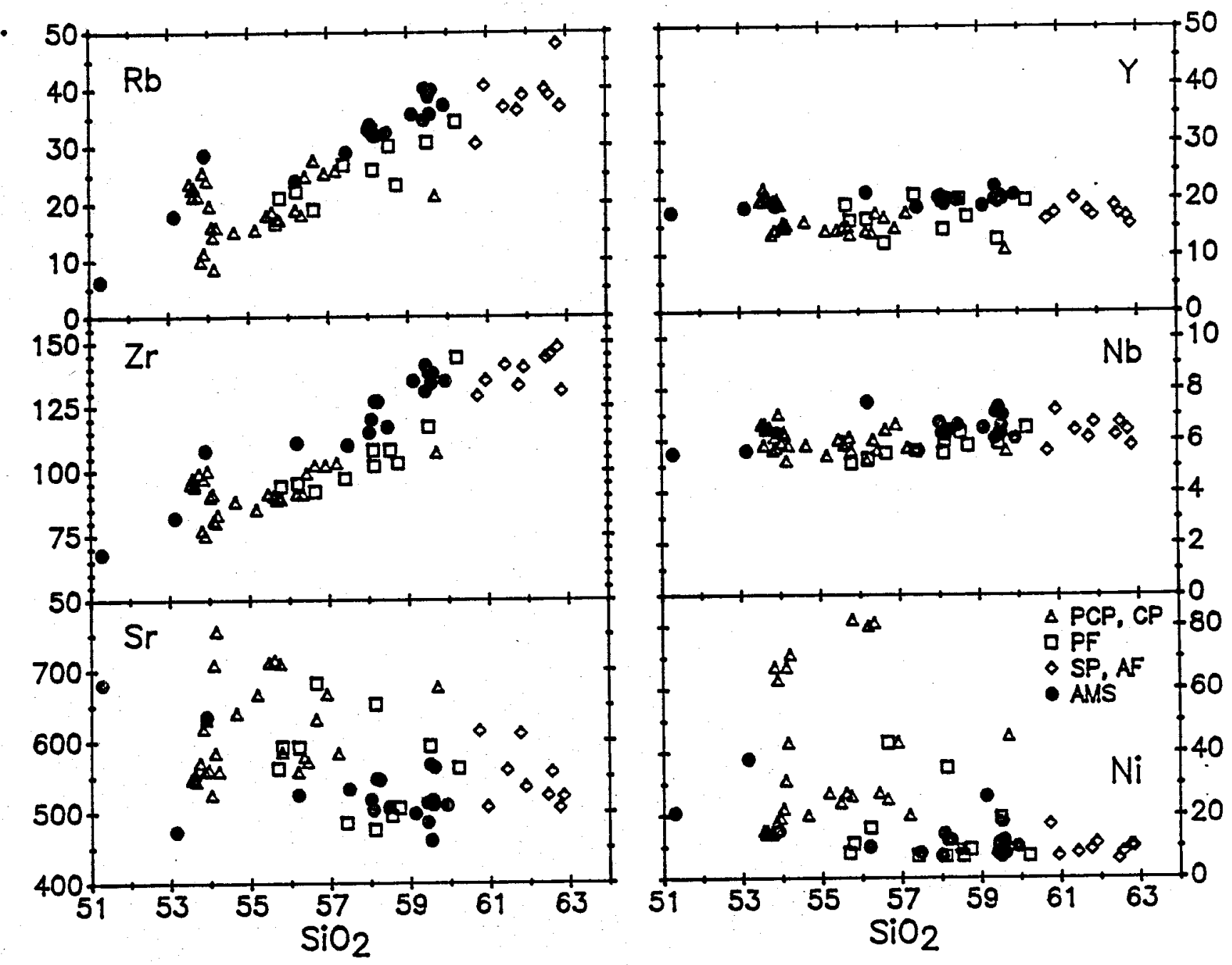

Figure 7. Trace element variation diagrams. Abbreviations as in Figure 4 . 
proportions of minerals derived from the least-squares modeling described previously, and distribution coefficients from Gill (1981), Fujimaki et al. (1984), and Green and Pearson (1987) (Table 2). The results of these calculations are plotted in Figure 8 . Variations in crystallizing mineralogy from Table 1 are reflected by inflections in the model crystallization trends.

Observed changes in concentrations of trace elements are incompatible with the interpretation that fractional crystallization is the major petrogenetic process relating sVC lavas. Specifically, $\mathrm{Rb}$ increases 8 -fold throughout the suite although fractional crystallization can only account for a 3fold increase (Figure 8 ). In contrast $\mathrm{Y}$ and $\mathrm{Nb}$ concentrations are nearly constant although fractional crystallization predicts a 2.5-fold increase with anhydrous crystallization assemblages and a 1.8-fold increase with hornblende-bearing assemblages. The range of SVC $\mathrm{zr}$ concentrations is matched fairly successfully by models involving hornblende crystallization, but is less than models involving anhydrous crystallization would predict. SVC $\mathrm{K}$ concentrations match those predicted by the fractional crystallization models successfully.

The discrepancy in observed versus predicted $\mathrm{Rb}$ concentrations cannot be resolved by any changes in the input parameters of the Raleigh fractionation equation. Even if the bulk distribution coefficient for $\mathrm{Rb}$ were 0 , least squares models with low enough proportions of liquid to explain the 8fold increase in $\mathrm{Rb}$ concentrations cannot be constructed. In order to explain the lack of variation in $\mathrm{Y}$ and $\mathrm{Nb}$ concentrations distribution coefficients for pyroxenes and hornblende would have to be around 5 and 3 , respectively, which far exceed experimental values. Alternatively $Y$ and $\mathrm{Nb}$ concentrations could be produced by crystallization of some trace mineral with extremely high distribution coefficients 
Table 2. Distribution coefficients used in trace element modelling (from Gill, 1981; Fujimaki and Tatsumoto, 1984). Y distribution coefficients are assumed to be those of $\mathrm{Yb}$.

$\begin{array}{llllllll} & \text { Rb } & K & \text { Kr } & Y & \text { Zr } & \text { Nb } & \text { Ni } \\ \text { ol } & 0.01 & 0.01 & 0.01 & 0.01 & 0.01 & 0.01 & 58.00 \\ \text { pl } & 0.07 & 0.11 & 1.80 & 0.05 & 0.01 & 0.02 & 0.01 \\ \text { Cpx } & 0.02 & 0.02 & 0.08 & 0.90 & 0.16 & 0.30 & 6.00 \\ \text { opx } & 0.02 & 0.01 & 0.03 & 0.46 & 0.05 & 0.35 & 8.00 \\ \text { hb } & 0.05 & 0.33 & 0.23 & 1.00 & 1.34 & 1.30 & 10.00 \\ \text { mt } & 0.01 & 0.01 & 0.01 & 0.25 & 0.40 & 1.00 & 10.00\end{array}$



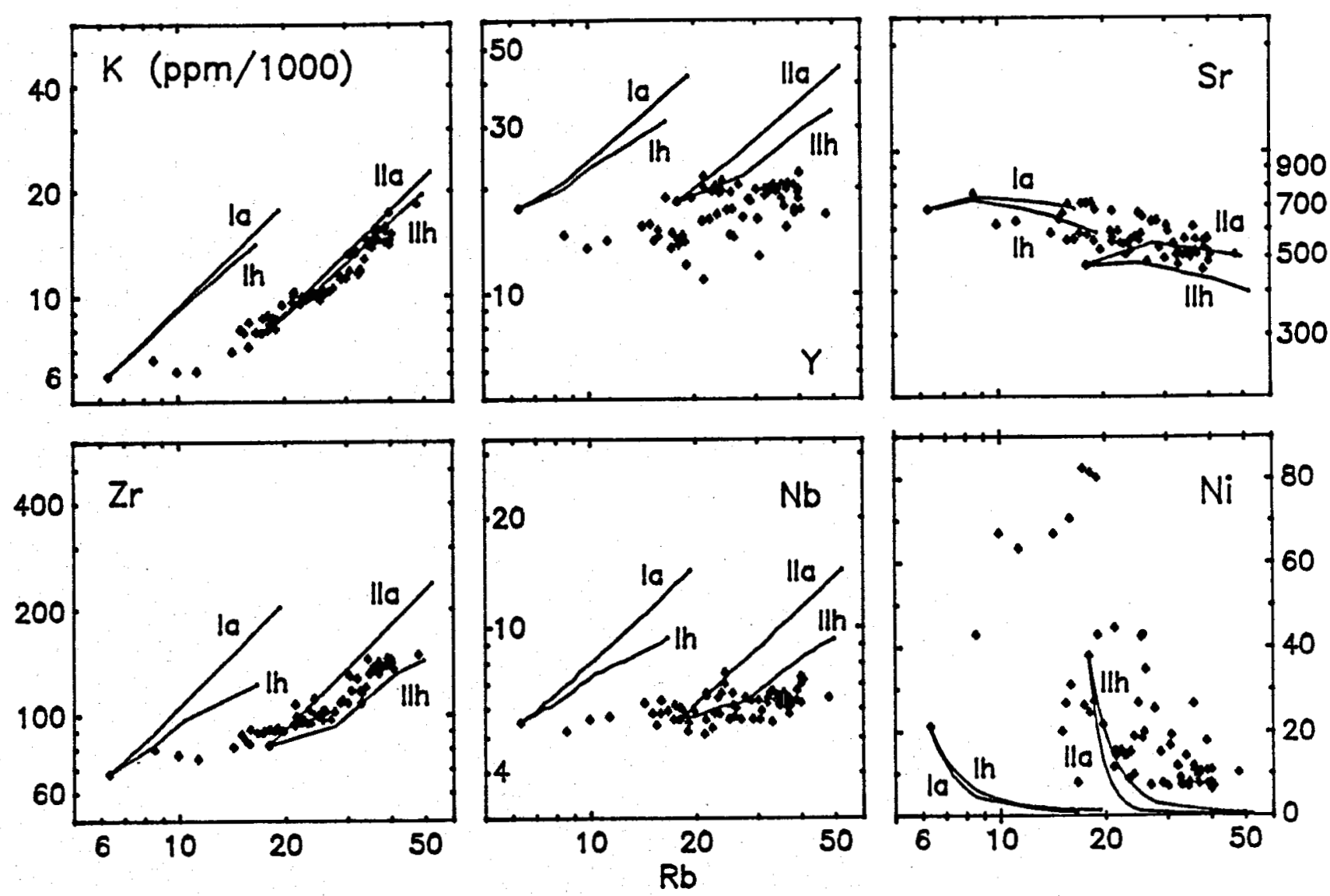

Figure 8. Trace element fractional crystallization models. Calculations are based on the least-squares modelling of Table 1 and distribution coefficients of Table 2. Ia and Ih correspond to path $1-2 b-7 b-8$ of Figure 5 for anhydrous and hornblende-bearing assemblages, respectively. IIa and IIh correspond to path $3-5 b-8$ of Figure 5 , also for anhydrous and hornblende-bearing assemblages. Note that the fractional crystallization models fail to reproduce the magnitude of $\mathrm{Rb}$ variation and lack of $\mathrm{Y}$ and $\mathrm{Nb}$ enrichment. 
for $\mathrm{Y}$ and $\mathrm{Nb}$. However, no such phases have been identified in thin section.

The wide range of $\mathrm{Rb}$ concentrations is compatible with a mechanism involving multiple parental magmas with variable $\mathrm{Rb}$, which have subsequently undergone fractional crystallization, but the narrow ranges of $\mathrm{Y}$ and $\mathrm{Nb}$ are not.

The wide range of $\mathrm{Rb}$ concentrations is also compatible with a mechanism involving mixing of Rb-rich country rock, or partial melts thereof, with the fractionating SVC lavas. Such models are difficult to evaluate numerically for two principal reasons. First, there is a lack of information about the composition of country rock in the spurr area. The available information is compiled in Table 3. Note that there are only a few elements in common between spurr and possible contaminants. Second, it is difficult to model partial melts of the crust, particularly for many trace elements, because the amount and nature of refractory phases with large concentrations of trace elements (e.g. zircon, sphene, etc.) are unknown and difficult to predict, and as long as such phases remain in the residue they will dominate the behavior of the elements they concentrate.

In spite of the above caveats, a few conclusions may be drawn about the possibility of contamination as a major petrogenetic process within the svC. Table 3 presents data for four possible contaminants. Mckinley sequence granites (MGR) are from the same intrusive unit that underlies the SVC, but were collected about $150 \mathrm{~km}$ north of Spurr (Lanphere and Reed, 1985). Jura-Cretaceous flysch samples (BC, Lanphere and Reed, 1985) are from the flysch sequence that the Mckinley sequence granites intrude. The same flysch sequence is also intruded by the plutonic rocks under Mt. Spurr. The other sets of samples (CHIG, UGA) are from regional studies of the chemistry of basement rocks of all lithologies $650 \mathrm{~km}$ to the southeast along the arc from spurr (Yount et al., 1978; 
Table 3. Mean compositions of SVC lavas and potential crustal contaminants. see text for descriptions of suites and references.

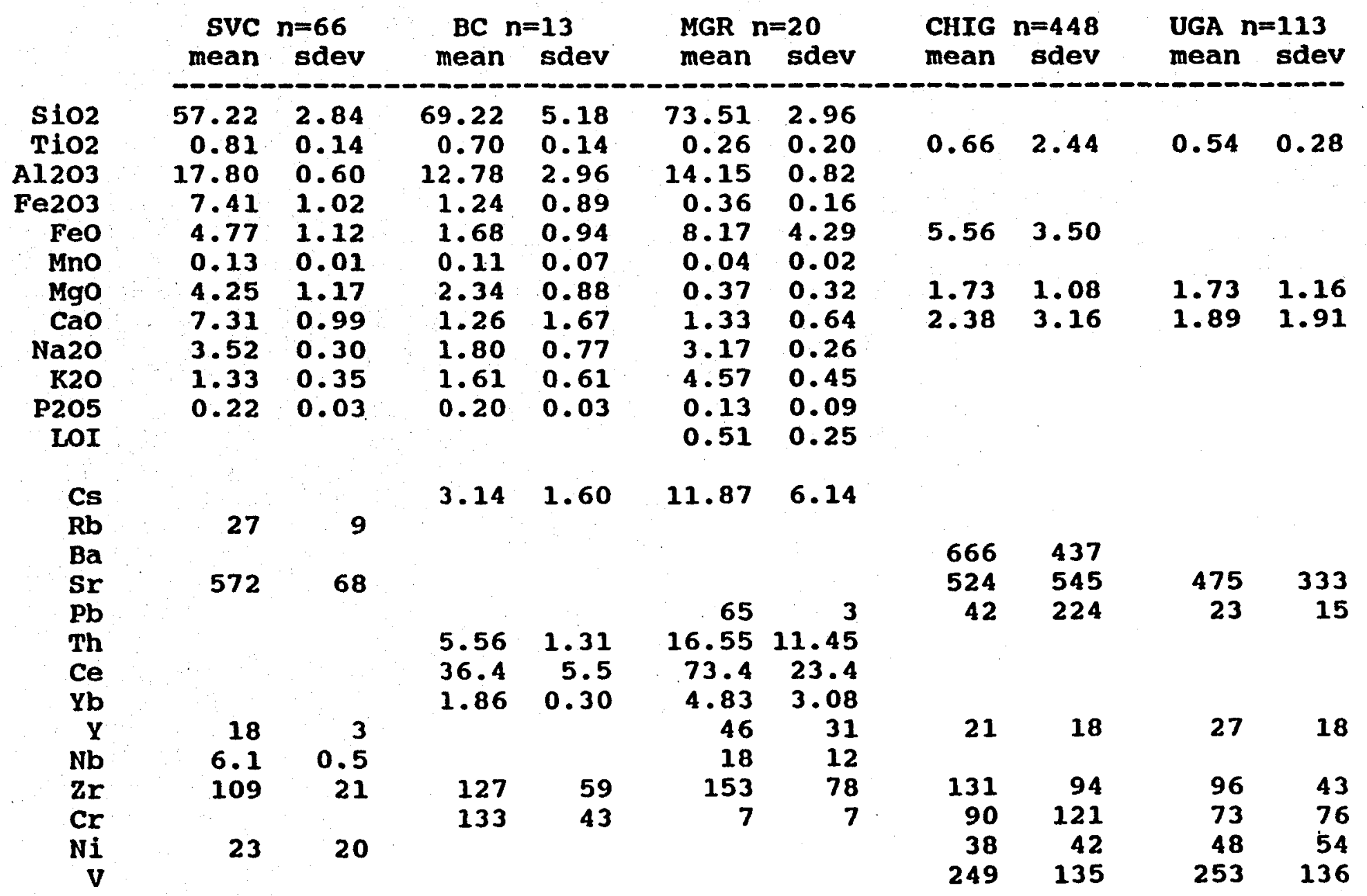


Pickthorn et al., 1979, Detterman et al., 1980). The CHIG and UGA data sets are averages over all surface lithologies, and are assumed to represent bulk uppermost crust. Both of these data sets are from south of the Bruin Bay Fault, and are therefore from Peninsula Terrane of slightly different lithology (wilson et al., 1985). There are few elements for which all data sets have been analyzed.

Bulk assimilation of Mckinley granites is unlikely because of their high concentrations of $\mathrm{Y}$ and $\mathrm{Nb}$. Admixture of large amounts of granite-derived partial melts is unlikely because of the high concentrations of $\mathrm{Th}$ and $\mathrm{Pb}$ in the granites. The maximum value for $T h$ for SVC lavas was obtained by $X$-ray diffraction in the course of this study, but is not reported in Appendix I because of the low precision of the results, which are near the XRF detection limit. The $\mathrm{Pb}$ value for svC lavas is an average value for Aleutian and Cascades highsilica calcalkaline andesites (Ewart, 1982). CHIG samples also have the low $Y$ concentrations necessary in a contaminant, although the moderately high, although extremely variable, $\mathrm{Pb}$ may preclude this average as a significant contaminant. The UGA data set has lower mean $\mathrm{Pb}$, but higher $\mathrm{Y}$, than CHIG. There is enough variation in CHIG and UGA that a lithology with the proper composition to be a contaminant could probably be selected.

Good analyses of $\mathrm{Pb}$ and $\mathrm{Th}$ at SVC, and $\mathrm{Rb}$ in the contaminant suites, both to determine absolute concentrations and to determine the rate of increase throughout the suite, would provide strong constraints on the amount of crustal material that could be added. Both BC and MGR are high in radiogenic $S r$ and heavy $O$ (Lanphere and Reed, 1985). Isotopic analyses of SVC lavas could also put strong constraints on possible assimilation/contamination models.

Finally, the curved nature of $K$ and $\mathrm{zr}$ vs. $\mathrm{Rb}$ in Figure 8 could be produced by assimilation or mixing with a crustal 
contaminant, but not by fractional crystallization or mixing with an evolved lava produced by fractional crystallization of mafic SVC lavas.

\section{PETROLOGY}

\section{Introduction}

Spurr Volcanic Complex lavas are porphyritic, with most lavas containing more than $30 \%$ crystals. Plagloclase is ubiquitous and far more abundant than other mineral species. olivine, orthopyroxene, and augite are found throughout the compositional range of the SVC, but olivine is in textural equilibrium only in the more mafic lavas, while orthopyroxene is in equilibrium in the more felsic lavas. Amphibole is volumetrically minor and confined to post-caldera units. Post-caldera units also contain abundant pyroxenite clots.

Evidence for disequilibrium is widespread, and includes petrographic evidence of textural disequilibrium, unexplainably large compositional ranges of plagioclase, small compositional range of amphibole, coexistence of phases which should not coprecipitate, and unexpectedly low Mg\# pyroxenes.

\section{plagioclase}

Plagioclase is ubiquitous in SVC lavas and is always the most common phenocryst. Modal concentrations (Appendix III) vary from $8 \%$ to $38 \%$, and are typically 25-30\% of the rock, and $75 \pm 10 \%$ of the phenocrysts. Modal concentrations do not vary systematically with $\mathrm{SiO}_{2}$. Plagioclase textures run the full gamut typical of andesites. Crystals can be twinned, clumped, broken, rounded, or euhedral; equant or slightly elongated, but very elongated only in the groundmass; and clear or spongy. spongy zones may be in the core, on the rim, or in between, and spongy cores may be either more or less anorthitic than surrounding clear rims. zoning can be normal, 
reverse, or oscillatory. Phenocrysts are typically a few millimeters in maximum dimension.

Core compositions show a broad trend of decreasing anorthite contents with increasing whole-rock $\mathrm{SiO}_{2}$ (Figure 9). The most calcic cores decrease from An90 in the basalt to An58 in the Mt. Spurr and ash flow samples (with a few exceptions). More mafic samples have a greater tendency for all grains to be normally zoned. Intermediate and silicic samples have a greater tendency for grains to be both normally and reversely zoned, and very strong reversals are restricted to the most silicic rocks.

Phenocryst core compositions span at least 10 mole $z$ An (and as much as 30 molez $A n$ ) in individual samples. Plagioclase compositions from individual samples can span in excess of 40 mole $\mathrm{An}$, including groundmass and rim compositions. The range of plagioclase compositions can be compared to experimental data in order to determine if it is possible that the plagioclase phenocrysts grew during closedsystem crystallization, or if some more complex process must be invoked. Figure 10 shows curves for predicted plagioclase compositions versus the amount of material crystallized for a Spurr andesite and basalt for various $\mathrm{CaO}-\mathrm{Na}_{2} \mathrm{O}$ exchange coefficients $\left(\mathrm{Kd}=\right.$ wtz $\left.\left(\mathrm{CaO} / \mathrm{Na}_{2} \mathrm{O}\right)_{\mathrm{pl}} /\left(\mathrm{CaO} / \mathrm{Na}_{2} \mathrm{O}\right)_{1 \mathrm{iq}}\right)$. The calculations were made by subtracting crystals of equilibrium composition from liquids in $5 \%$ crystallization increments. A proportion of clinopyroxene similar to that typical of the lavas was subtracted simultaneously in order to track the CaO composition of the evolving liquid accurately. CaO - $\mathrm{Na}_{2} \mathrm{O}$ exchange coefficients are not well known, but the data of Drake (1976, Table 2) suggest that values between 1 and 2 are appropriate. The data of Drake (1976) do contain high values of $\mathrm{Ca} a_{\mathrm{pl}} / \mathrm{Ca}_{1}$ at low temperatures, which result in exchange coefficients of 3 to 5.5, which are anomalously high compared to the rest of the data. Exchange coefficients of 2 to 3 most closely reproduce the trend of SvC lavas in $\mathrm{CaO}, \mathrm{Na}_{2} \mathrm{O}$, 


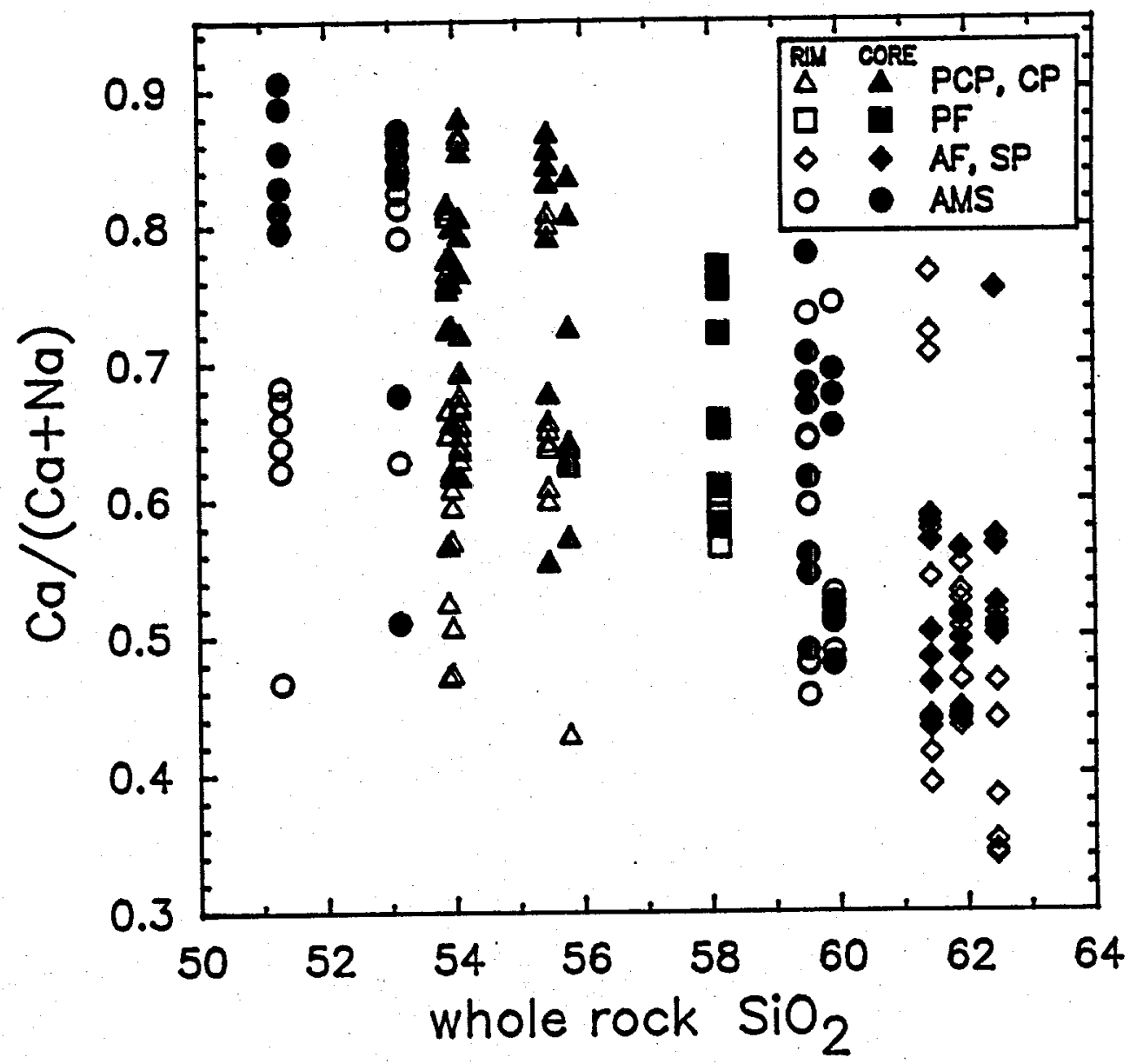

Figure 9. $\mathrm{Ca} /(\mathrm{Ca}+\mathrm{Na})$ of plagioclase vs. whole-rock $\mathrm{SiO}_{2}$ of the enclosing magma. Abbreviations as in Figure 4. 
$\mathrm{CaO} / \mathrm{Na}_{2} \mathrm{O}$, and $\mathrm{CaO} / \mathrm{Al}_{2} \mathrm{O}_{3}$. An exchange coefficient of less than 1 causes $\mathrm{Na}_{2} \mathrm{O}$ contents to decrease, rather than increase as they do in the SVC (Figure 4). An exchange coefficient of more than 3 causes a much more rapid decrease in $\mathrm{CaO}$ and $\mathrm{CaO} / \mathrm{Al}_{2} \mathrm{O}_{3}$ than is observed in SVC lavas.

In general, the range of plagioclase core compositions for individual samples exceeds that which could be produced by equilibrium, closed system crystallization. The samples for which plagioclase compositions are known average $25 \%$ plagioclase by volume. Figure 10 indicates that a maximum range of $12 \%$ An can be produced by crystallization of this amount of plagioclase. This is a maximum estimate of the range of An that could be produced, since it is calculated using the total volume of plagioclase phenocrysts, but the range of compositions of only the cores.

Variations in plagioclase chemistry beyond those compatible with crystallization could be due to several mechanisms, such as polybaric crystallization, crystallization at variable water pressures, inclusion of plagioclase xenocrysts, or removal of a portion of the plagioclase phenocrysts, so that the proportions of crystals in the lava do not reflect the total crystallization history of the magma. It is not possible to make unequivocal choices from the above mechanisms.

\section{olivine}

Olivine is present in SVC lavas from the least to the most siliceous. In lavas with less than about $56 \% \mathrm{siO}_{2}$ olivine is always euhedral and frequently has well developed skeletal terminations. Most, but not all, lavas in this silica range contain olivine. At higher $\mathrm{SiO}_{2}$ contents olivine shows pronounced textural signs of disequilibrium, such as pyroxenespinel symplectite coronas or jackets of tightly interlocked pyroxenes and plagioclase. Modal concentrations of olivine are usually near or less than 1\%, with the exception of a few 


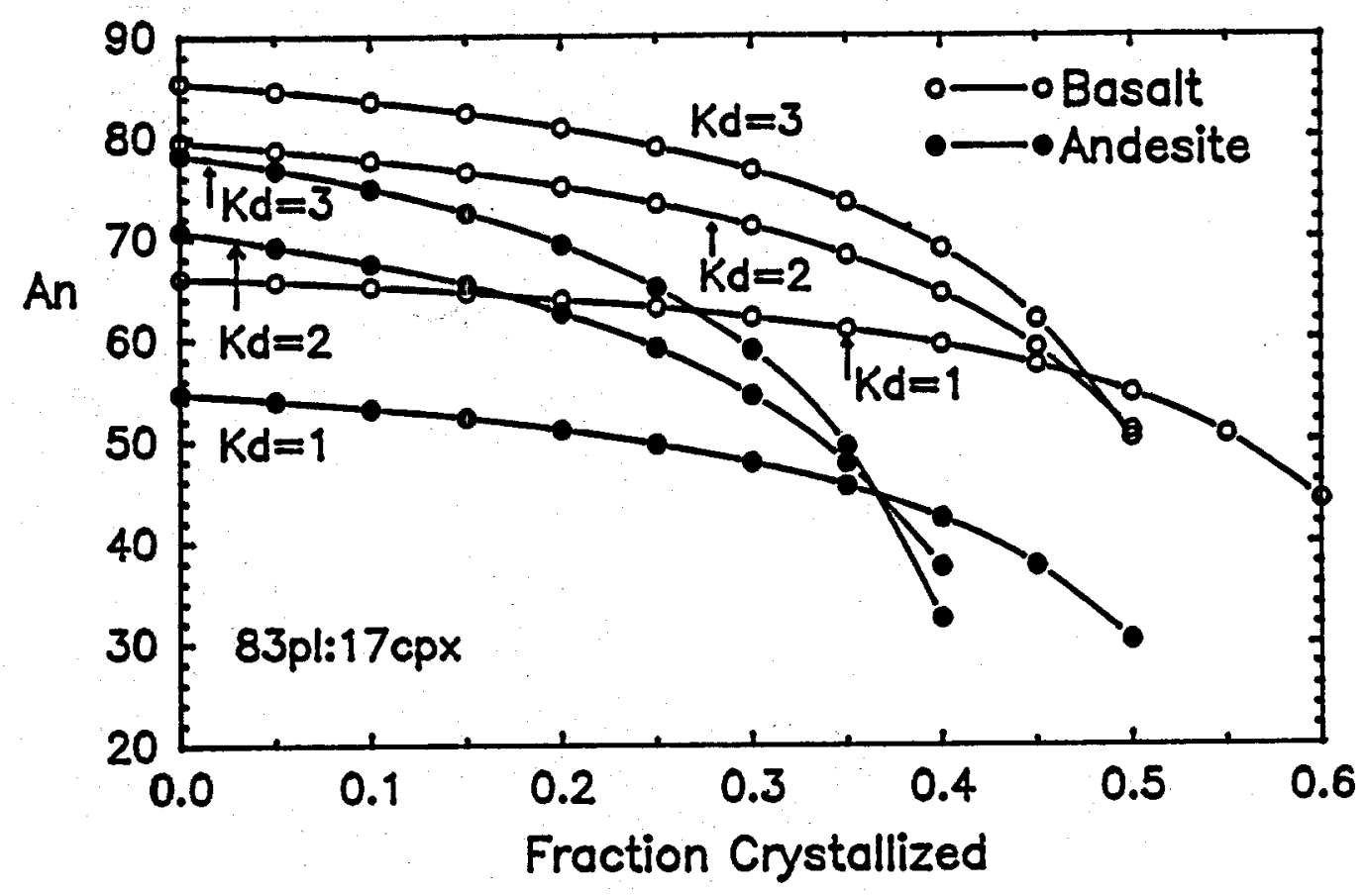

Figure 10. Change in calculated plagioclase composition with fractional crystallization of SVC andesite and basalt for a range of $\mathrm{kd} / \mathrm{pl}-1$. 
Crater Peak flows and the most mafic ancestral Mt. Spurr flows, which contain up to 5.88 olivine. Olivine crystals often contain small euhedral octahedra of translucent, brown, cr-rich spinel. This suggests that those olivines which contain chromite crystallized before the magma became saturated with clinopyroxene, which competes effectively for Cr and drives the spinel phase to Fe-rich compositions.

Olivine compositions are in Appendix IV, and $\mathrm{Mg} \#$ are plotted against the Feot/Mgo of the enclosing rock in Figure 11. Lines in Figure 11 are drawn for equilibrium between olivine and the whole-rock composition at the FMQ and NNO oxygen buffers, and one log unit fO2 above NNO. These lines are constructed for a value of the Fe-Mg exchange coefficient $\mathrm{Kd}{ }^{\mathrm{Fe}} / \mathrm{Mg}$ ol-1 (moles $\left(\mathrm{FeO}_{\mathrm{Ol}} / \mathrm{MgO}_{\mathrm{Ol}}\right) /\left(\mathrm{FeO}_{1} / \mathrm{MgO}_{1}\right)$ ) of 0.30 (Roeder 1974), and $\mathrm{Fe}_{2} \mathrm{O}_{3} / \mathrm{FeO}$ calculated for each sample using the empirical relation of sack et al. (1980), equations of the various buffers from chou (1978), assumed temperatures (which were derived by regressing all andesite temperature estimates from Table 4.1 of Gill (1981)), and the bulk compositions of individual samples. Inflections of the equilibrium lines are produced by variable bulk compositions and, to a much lesser extent, inferred temperatures, at constant Feot/Mgo. $\mathrm{Kd}^{\mathrm{Fe} / \mathrm{Mg}}$ ol-1 of 0.3 is the recommended value of Roeder and Emslie (1970), Longhi et al. (1978), and Roeder (1974), and is independent of temperature. (Note that studies which find an apparent dependence of $\mathrm{kd}$ on temperature have poorly controlled oxygen fugacities, which result in unknown $\mathrm{Fe}^{3+} / \mathrm{Fe}^{2+}$, and thus poor determinations of $\mathrm{FeO} / \mathrm{MgO}_{1}$, as recognized by Green et al. (1975) and Usselman and Lofgren

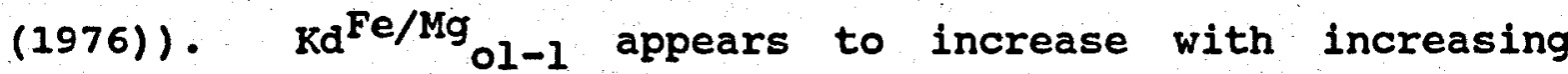
pressure to approximately 0.33 8-10 Kbar (Ford et al., 1983; data of Bender et al., 1978, and Baker and Eggler, 1987).

Many of the rocks have olivine compositions nearly compatible with liquidus crystallization at reasonable oxygen fugacities, and successive nucleation of crystals during the 


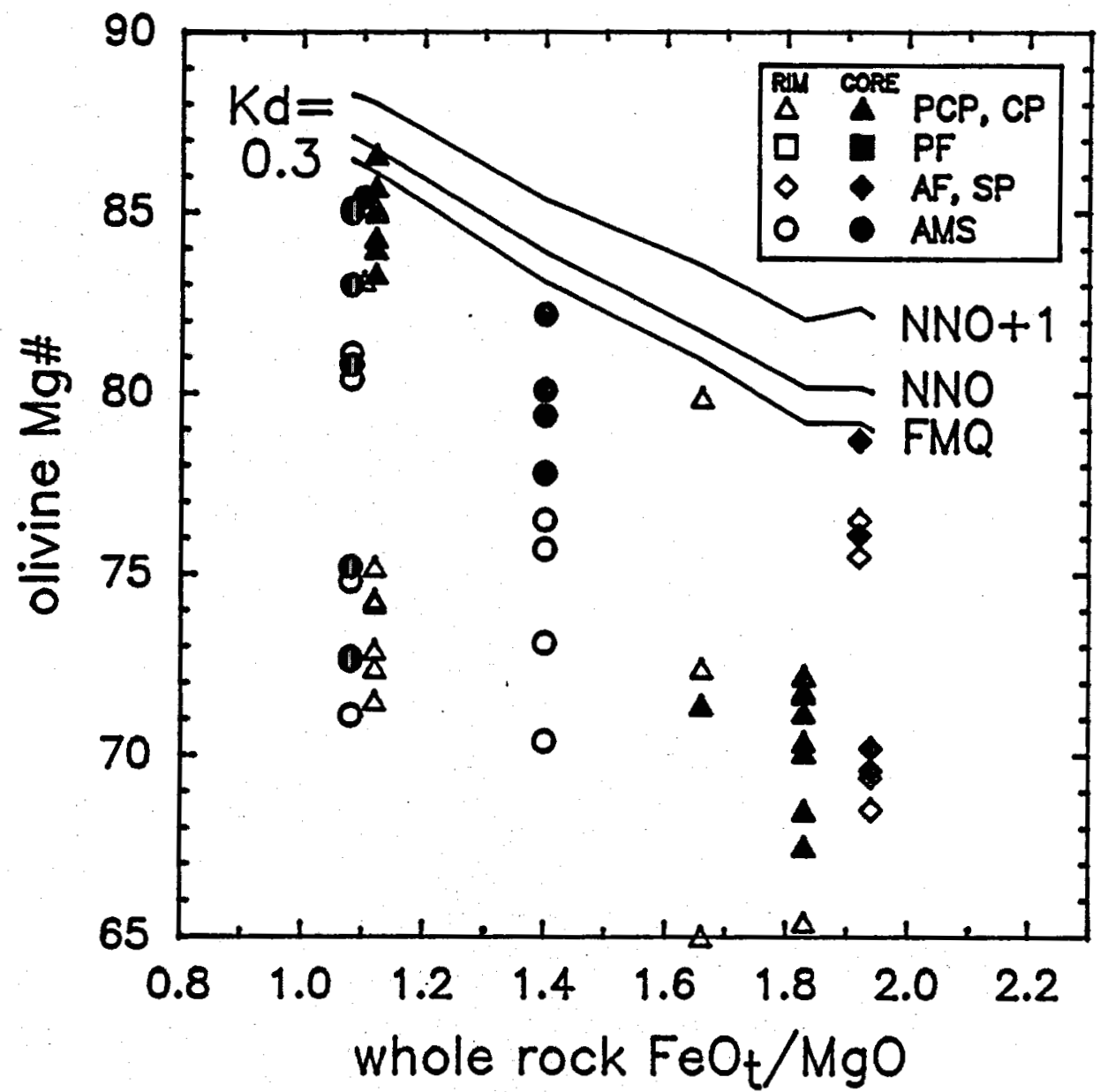

Figure 11. Olivine $\mathrm{Mg} \#$ vs. $\mathrm{FeO}_{\mathrm{t}} / \mathrm{MgO}$ of the enclosing rock. Equilibrium lines are constructed for $\mathrm{Kd}^{\mathrm{Fe} / \mathrm{Mg}}$ ol-1=0.3 and with whole-rock $\mathrm{Fe}^{3+} / \mathrm{Fe}^{2+}$ calculated as described in the text. Inflections of the equilibrium lines reflect the effect of different bulk compositions on $\mathrm{Fe}^{3+} / \mathrm{Fe}^{2+}$. Abbreviations as in Figure 4. 
evolution of the residual liquid. Even the large range of core compositions for OFT-B07 (the sample with lowest FeOt/MgO in Figure 11) can be produced by successive nucleation and growth of ollvine during the growth of the $9 \%$ olivine and augite in the rock, but only if significant amounts of magnetite or hornblende are not coprecipitating and inhibiting iron enrichment in the residual melt. Olivine in PCP-A05 is too iron rich to be in equilibrium with the melt, but this sample contains dunite clots which were in the process of disaggregation when the rock cooled, thus some of the discreet crystals may have been derived from such clots and may be xenocrysts. Free olivine crystals in PCP-A05 are rounded, have thin reaction rims, and are the same composition as crystals within the dunite clots. olivine in the AF and SP samples are in textural disequilibrium.

The fact that many samples fall slightly below the equilibrium curves can be due to our failure to analyze the most mafic crystal (which is quite likely considering the small number of analyses per sample), or could reflect crystallization at elevated, although crustal, pressure.

Olivine is normally zoned (by as much as $\mathrm{FO}_{10}$ ) in mafic samples, where it is euhedral and in apparent equilibrium. Conversely, olivine is unzoned in more evolved samples, where it is in textural disequilibrium, and may be being resorbed. olivine in dunite clots is, for the few crystals analyzed, unzoned.

olivine textures and chemistry suggest that olivine is a stable precipitating phase in SVC magmas of up to about $56 \%$ $\mathrm{SiO}_{2}$. In more evolved lavas olivine crystals are xenocrysts, at least some of which come from deep-seated cumulate bodies.

\section{clinopyroxene}

Clinopyroxene is ubiquitous in the SVC and comprises between 0.25 and 8.25 volume percent ( $3.5 \%$ on average) of the 
mode (Appendix V), and $10 \pm 6 \%$ of the phenocrysts. Clinopyroxene and orthopyroxene are in subequal proportions in SVC lavas. Phenocrysts are typically about a millimeter long, stubby to equant, euhedral to subhedral, and only slightly zoned. zoning is generally, but not always, normal. clinopyroxene also occurs as polycrystalline, monomineralic clots which are described in more detail below.

The clinopyroxenes are augites of restricted composition $\left(\mathrm{En}_{40-53} \mathrm{Fs}_{8-19} \mathrm{WO}_{36-44}\right)$. The augites have compositions that are broadly typical of others from the Aleutian arc (Kay and Kay, 1985). $\mathrm{SiO}_{2}$ and CaO remain constant with increasing Mg\#, $\mathrm{Al}_{2} \mathrm{O}_{3}$ increases slightly, $\mathrm{MnO}$ and $\mathrm{Na}_{2} \mathrm{O}$ decrease slightly, and $\mathrm{TiO}_{2}$ is very scattered. There are no $\mathrm{Cr}_{2} \mathrm{O}_{3}$ analyses for the most mafic augites. For the remaining samples $\mathrm{Cr}_{2} \mathrm{O}_{3}$ contents are always less than $0.10 \mathrm{wtz}$, and usually less than 0.05 wtz. coefficients for equations describing the average chemistry of SVC clinopyroxenes are in Appendix $v$. Concentrations of nonquadrilateral components (calculated by the scheme of Lindsley, 1983) sum to $7 \pm 4 \%$, and are independent of quadrilateral-component composition, with the exception of AlcaTs, which is slightly higher in En-rich, wo-poor pyroxenes.

Wo concentrations of pyroxenes, based on the graphical twopyroxene thermometer of Lindsley (1983) yield temperatures between 800 and 1150 degrees $c$. Wo concentrations are marginally higher in the ashflow samples than in the crater Peak samples, indicating slightly lower temperatures for the more evolved samples.

Augite Mg\#s are plotted against the $\mathrm{FeO}_{\mathrm{t}} / \mathrm{MgO}$ of the enclosing rock in Figure 12. There is broad overlap in pyroxene composition between samples, although the most magnesian core compositions tend to drop with increasing whole-rock $\mathrm{FeO}_{t} / \mathrm{MgO}$, as expected. With few exceptions, the most magnesian cores in individual samples have much lower Mg\# 


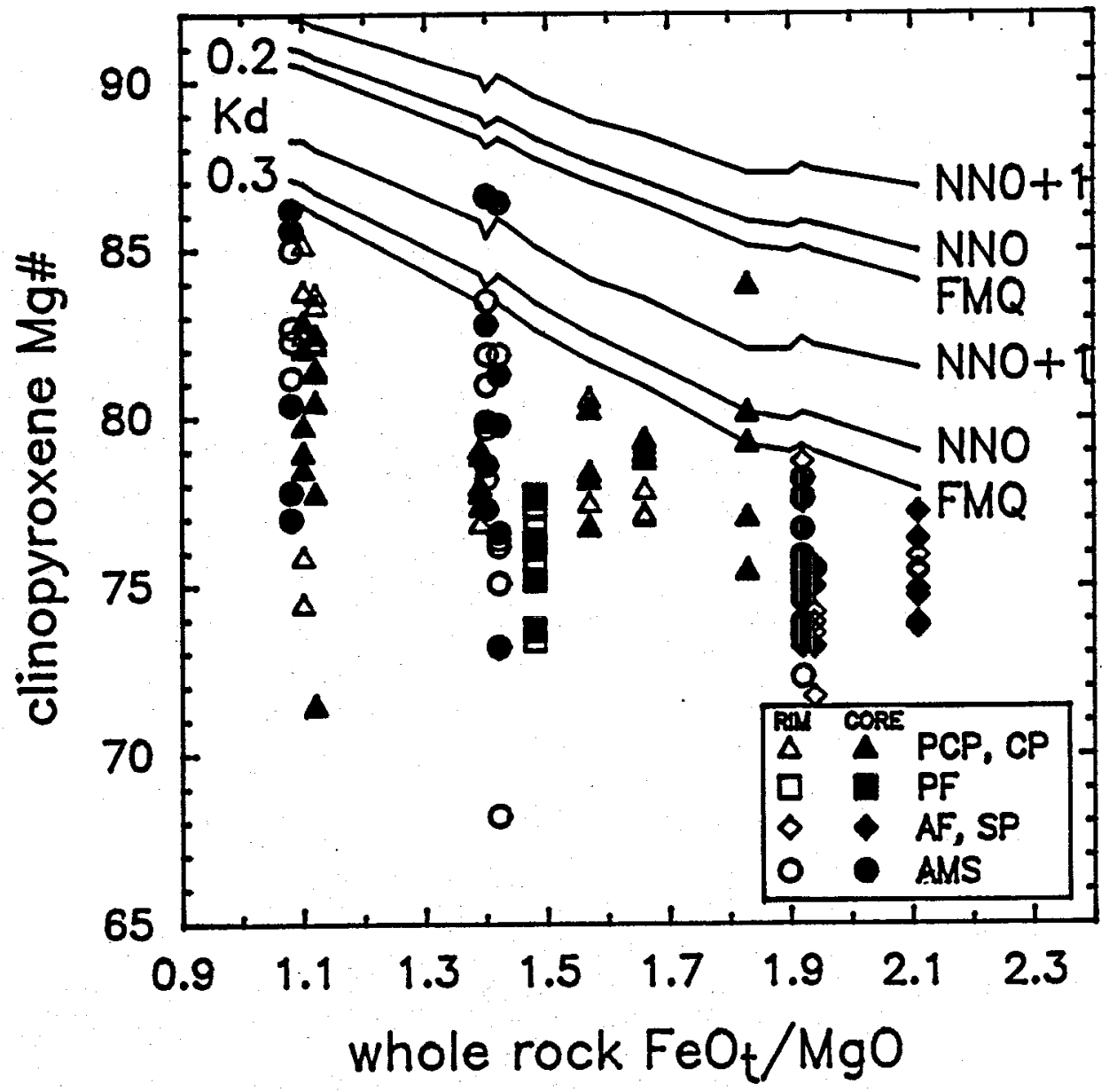

Figure 12. Clinopyroxene $\mathrm{Mg \#}$ vs $\mathrm{FeO}_{\mathrm{t}} / \mathrm{MgO}$ of the enclosing rock. Equilibrium lines were constructed in the same manner as for olivine. Abbreviations as in Figure 4. 
than would be expected if they were in equilibrium with the whole rock. $\mathrm{Kd}^{\mathrm{Fe} / \mathrm{Mg}} \mathrm{cpx-1}$ has not been studied as extensively as $\mathrm{Kd} F / \mathrm{Mg}_{\mathrm{ol}-1}$; but values of around 0.25 are typical of values observed in experimental runs at low to moderate pressure (e.g. Grove et al., 1982; Baker and Eggler, 1987).

The following are possible processes which might produce augite compositions less mafic than expected, along with brief discussions of their possible effectiveness:

1) Augite compositions less magnesian than whole rock chemistry predicts could be due to failure to analyze the most magnesian grain in each sample. However, the homogeneity of compositions within many samples suggests that the observed ranges are representative.

2) Augite might have crystallized further below the liquidus than another ferromagnesian phase. Thus it is conceivable, especially for the mafic samples, that magma cooled to the olivine saturation surface and precipitated olivine for an interval before nucleating augite. The augite would then precipitate from a liquid composition less magnesian than the whole rock. This mechanism is less appealing for more siliceous samples, where textural relations suggest that augite is the first mafic phase to crystallize (i.e. there is no mafic phase which precedes clinopyroxene during crystallization).

3) Whole-rock $\mathrm{FeO}_{t} / \mathrm{MgO}$ could be substantially less than those of liquids because of selective phenocryst accumulation or fractionation. Accumulation of either $2.5 \%$ (by weight) olivine, $5 \%$ orthopyroxene, or 88 clinopyroxene could lower the whole-rock $\mathrm{FeO}_{t} / \mathrm{MgO}$ by about 0.5 , or accumulation of 
all mafic phases together could lower the whole-rock $\mathrm{FeO}_{t} / \mathrm{MgO}$ by about 1.5 (Figure 13). These crystal proportions equal or exceed those of the magmas, but are insufficient by about half to explain the unexpectedly low Mg\# of the augites. Alternatively, selective removal of about 58 magnetite could also lower whole-rock $\mathrm{FeO}_{t} / \mathrm{MgO}$ by about 1.5. Note that this requires that magnetite be separated from the magma, and from the pyroxenes, after pyroxene crystallization.

4) $\mathrm{Kd}^{\mathrm{Fe}} / \mathrm{Mg}_{\mathrm{cpx}-1}$ may be high. If $\mathrm{Kd}^{\mathrm{Fe} / \mathrm{Mg}} \mathrm{cpx-1}$ were 0.40 (at NNO) then augites of the observed composition would be in equilibrium with the wholerock compositions. There is no experimental support for such high values of $\mathrm{Kd}^{\mathrm{Fe} / \mathrm{Mg}} \mathrm{Cpx}_{\mathrm{Cp}}$, however.

\section{orthopyroxene}

orthopyroxene is present in all but the most mafic SVC magmas. It comprises 0.5 to $8.5 \%$ (3.8\% on average) of the mode (Appendix VI), and $10 \pm 6 \%$ of the phenocrysts. On average, clinopyroxene and orthopyroxene are present in subequal amounts, although the cpx/opx ratio ranges between 0.05 and 8.0 in extreme cases. Phenocrysts are typically about a millimeter long, have aspect ratios of 2 to 3 , are euhedral to subhedral, and only slightly zoned. zoning can be normal or reversed, and is more apt to be reversed in mafic, olivine bearing, samples.

Orthopyroxenes have a wide compositional range $\left(E n_{53-}\right.$ $\left.82 \mathrm{Fs}_{15-46} \mathrm{Wo}_{0.4-5}\right)$, although those orthopyroxenes more iron rich than $\mathrm{En}_{60}$ are rare and form rounded crystal cores of unusual composition which are probably of xenocrystic origin. $\mathrm{SiO}_{2}, \mathrm{Al}_{2} \mathrm{O}_{3}$, and $\mathrm{CaO}$ increase with increasing En, Mno decreases, and $\mathrm{TiO}_{2}$ and $\mathrm{Na}_{2} \mathrm{O}$ remain constant. Coefficients of linear equations describing orthopyroxene chemistry are in Appendix VI. Concentrations of nonquadrilateral components 


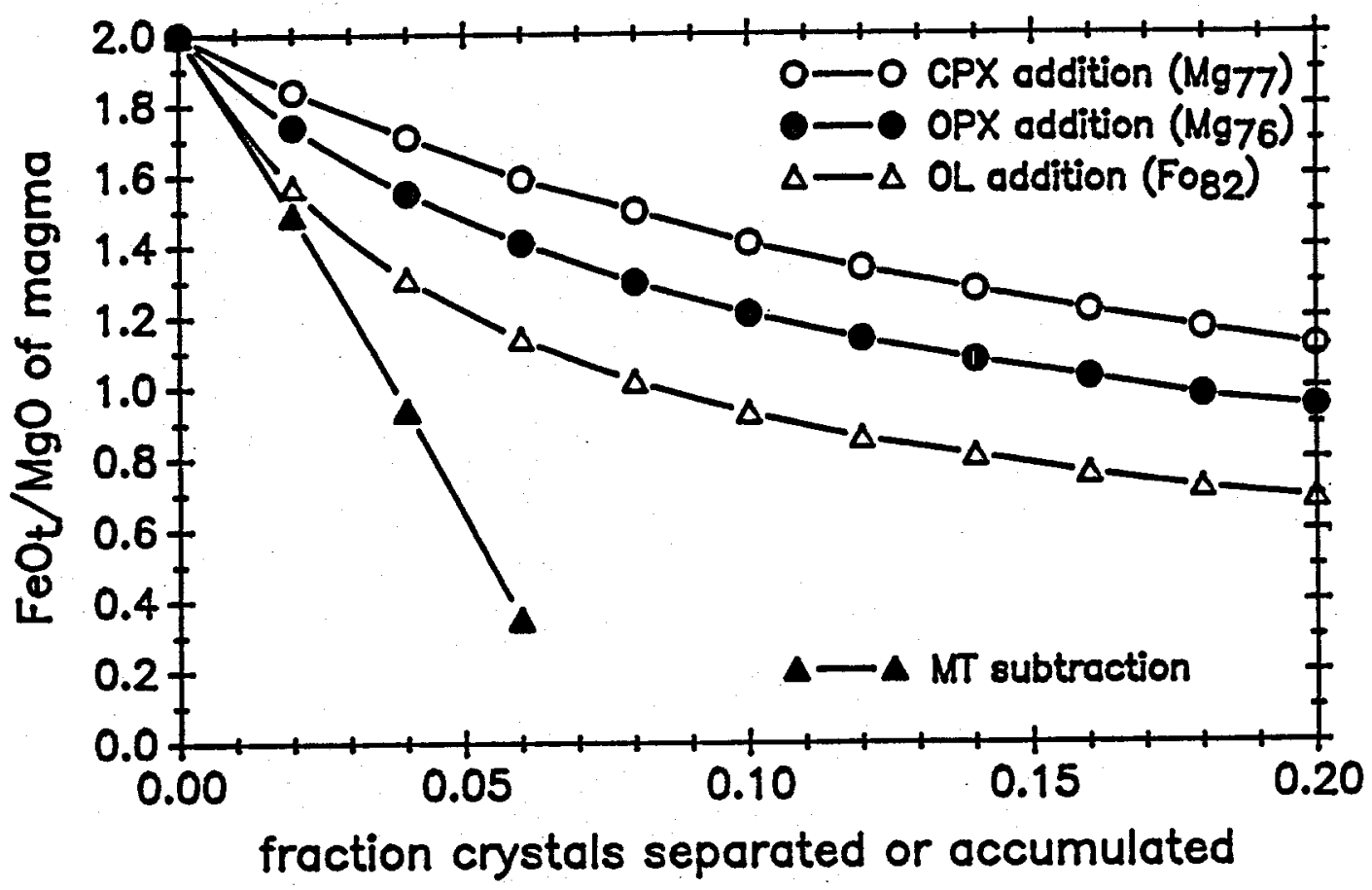

Figure 13. Effect of olivine and pyroxene addition and magnetite subtraction on the $\mathrm{FeO}_{t} / \mathrm{MgO}$ of a typical SVC andesite. 
(calculated by the method of Lindsley, 1983) sum to $3.6 \pm$ 2.7\%. Amounts of nonquadrilateral components whose abundances are dictated by $\mathrm{Na}$ and $\mathrm{Ti}$ are independent of $\mathrm{En}$. However, as with the augites, $\mathrm{Al}_{2} \mathrm{O}_{3}$ (and thus $\mathrm{R}^{2} \mathrm{R}^{3} \mathrm{AlSiO} 6$, whose abundance is controlled by $\mathrm{Al}$ excess over $\mathrm{Na}+\mathrm{Ti}$ ) increases with increasing $\mathrm{Mg}$. Wo contents are independent of the composition of the enclosing rock.

The Mg\#s of orthopyroxenes are plotted against whole-rock $\mathrm{FeO}_{t} / \mathrm{MgO}$ in Figure 14. The pattern of variation of chemistry is very similar to that of the augites discussed previously. There is broad overlap in crystal chemistry between samples, but the most magnesian cores in each sample generally become less magnesian with increasing whole-rock $\mathrm{FeO}_{t} / \mathrm{MgO}$. As with the augites, opx crystals are more iron-rich than expected if opx were a liquidus or near-liquidus phase, if whole-rock compositions closely reflect liquid compositions, and if $\mathrm{Kd}^{\mathrm{Fe} / \mathrm{Mg}}{ }_{\mathrm{opx}-1}$ is $0.3 . \mathrm{Kd}^{\mathrm{Fe}} / \mathrm{Mg}_{\mathrm{opx}-1}=0.3$ is derived from the composition of coexisting augite and orthopyroxene given by Lindsley (1983) and the value of $\mathrm{Kd}^{\mathrm{Fe} / \mathrm{Mg}} \mathrm{cpx-1}$ given by Grove et al. (1982). Baker and Eggler (1987) give slightly lower values of $\mathrm{Kd}^{\mathrm{Fe} / \mathrm{Mg}}$ opx-1. The same possible explanations set forward for the iron-rich nature of the augites could apply to the orthopyroxenes.

\section{Amphibole}

Amphibole occurs in minor or trace amounts in some of the samples from proto-Crater Peak, crater Peak, the pyroclastic fan, and Mt. Spurr, but not in samples from the ancestral Mt. Spurr or the ash flows. Amphibole usually occurs in such small amounts, however, that its absence from individual thin sections may not mean that it is absent from the flow, or even the hand specimen from which the thin section was cut. It is in textural equilibrium (euhedral and without reaction rims) only in pumice from the 1953 eruption. In most samples amphibole crystals are rounded or broken and coated with heavy 


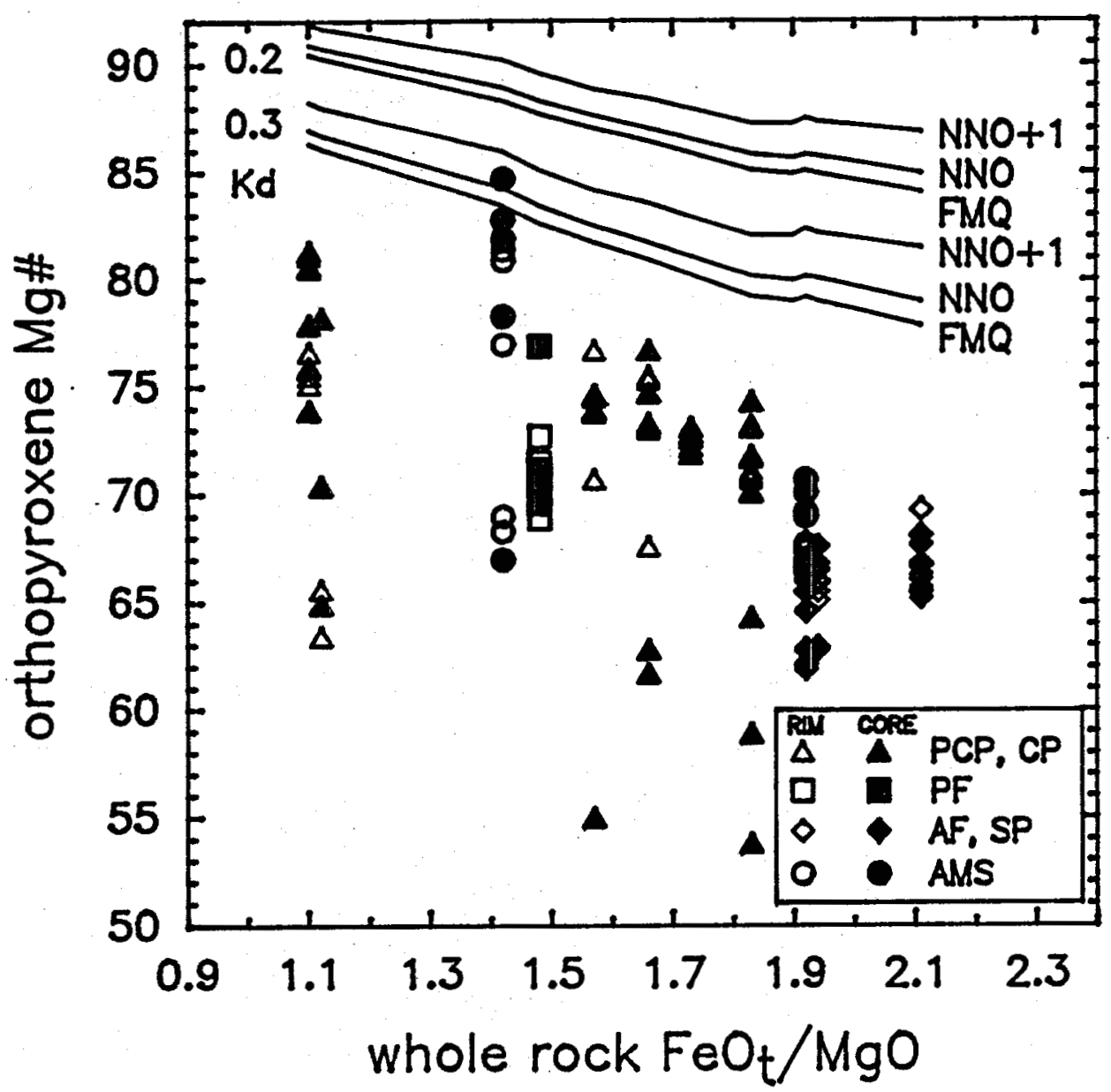

Figure 14. Orthopyroxene $\mathrm{Mg} \#$ vs $\mathrm{FeO}_{\mathrm{t}} / \mathrm{MgO}$ of the enclosing rock. Equilibrium lines were constructed in the same manner as for olivine. Abbreviations as in Figure 4. 
opacite rims. Crystals are typically subequant and as large as $1.3 \mathrm{~mm}$ in maximum dimension. In sample PCP-B01, from proto-Crater Peak, amphibole occurs as large platy crystals which armour small clinopyroxenite nodules. Pleochroism of amphibole in the pumice from the 1953 eruption is in shades of green and brownish-green, while crystals in all other samples are brown to bright reddish-brown.

All SVC amphibole analyses are pargasite according to the classification scheme of Leake (1978) as modified by Hawthorne (1981). Chemical compositions of amphiboles and coefficients of linear equations describing amphibole chemistry are in Appendix VII. As Mg\# decreases over the range of the samples $(\mathrm{Mg} \#=72$ to 96$) \mathrm{SiO}_{2}, \mathrm{CaO}, \mathrm{Na}_{2} \mathrm{O}$, and $\mathrm{K}_{2} \mathrm{O}$ remain fairly constant, $\mathrm{Al}_{2} \mathrm{O}_{3}$ decreases from about $13.5 \%$ to $11.5 \%$ (although tetrahderal $\mathrm{Al}$ remains constant), and $\mathrm{TiO}_{2}$ increases from about $2.0 \%$ to 3.8\%, $\mathrm{F}$ and $\mathrm{Cl}$ are independent of $\mathrm{Mg \#}$ and average $0.11 \pm 0.068$ and $0.02 \pm 0.028$, respectively.

In most respects, SVC amphiboles overlap the fields of previously described Aleutian amphibole. In general, they are intermediate in composition between amphiboles from lavas (Daley, 1986; Kay and Kay, 1985) and mafic and ultramafic nodules proposed to have formed at lower crustal or upper mantle pressures (Conrad and Kay, 1984; DeBari et al., 1987). In their consistently high alkali and $\mathrm{Al}_{2} \mathrm{O}_{3}$, and low $\mathrm{SiO}_{2}$ contents, they resemble the nodule amphiboles, but in their variable $\mathrm{Mg} \#$ and high $\mathrm{Na}_{2} \mathrm{O} / \mathrm{K}_{2} \mathrm{O}$ they resemble amphiboles from lavas. The following aspects of their chemistry are noteworthy.

First, svc amphiboles occupy the upper end of the Aleutian $A I^{I V}$ distribution, and, with the exception of amphibole from Mt. Spurr, have higher $\mathrm{Na}+\mathrm{K}$ than other Aleutian lavas (Figure 15). In terms of $A I I V$ and alkali content the sVC amphiboles more closely resemble those of cumulate and composite xenoliths from the lower crust or upper mantle 


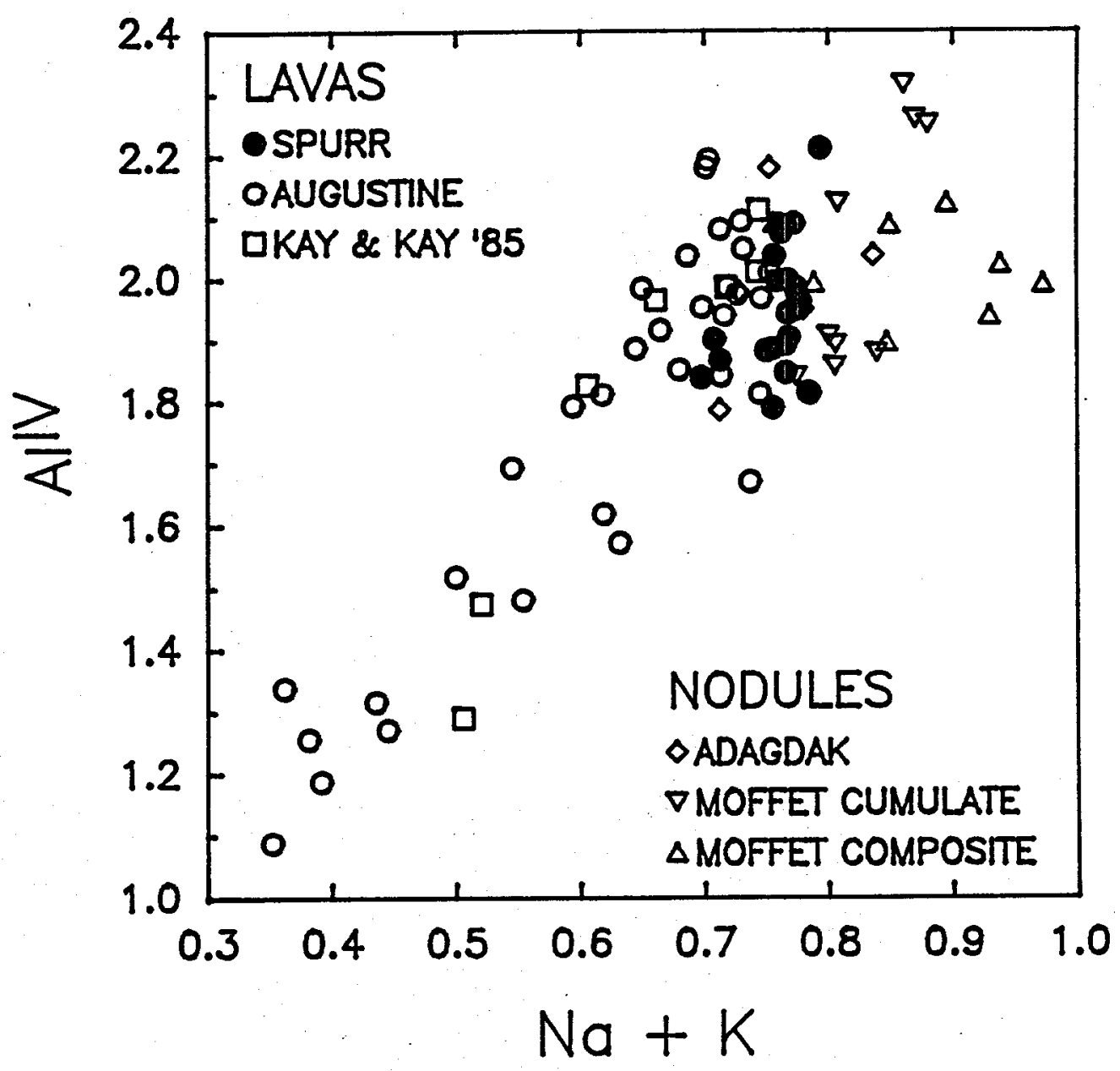

Figure 15. Al IV vs. Na+K for SVC hornblendes and other Aleutian hornblendes from Daley (1986), Kay and Kay (1985), DeBari et al. (1986) and Conrad and Kay (1984). 
(Conrad and Kay, 1984; DeBari et al. 1987). $\mathrm{Al}$ IV and (Na + K) are strongly temperature dependant (see Hammarstrom and Zen, 1986, for summary) so svc amphiboles all must have crystallized at high temperature.

Second, $\mathrm{Na}+\mathrm{K}$ and $\mathrm{Al}$ IV remain constant with decreasing Mg\#, while $\mathrm{Al}_{2} \mathrm{O}_{3}$ decreases by about 2 wt $\%$. Because $\mathrm{Al}_{2} \mathrm{O}_{3}$ can be used as a geobarometer in igneous amphibole (Hammarstrom and Zen, 1986; Hollister et al., 1987) the combined behavior of $\mathrm{Al}_{2} \mathrm{O}_{3}$ and $\mathrm{Na}+\mathrm{K}$ and $\mathrm{Al}$ IV suggest near isothermal crystallization at pressures of $8.2 \pm 1$. to $6.2 \pm 1 \mathrm{kbar}$, or between 19 and $25 \mathrm{~km}$ deep in the crust. (Note that total Al does decrease with decreasing Mg\#, suggesting that there was polybaric crystallization even though it cannot be statistically resolved with the error estimates of Hollister et al., 1987).

Third, $\mathrm{TiO}_{2}$ concentrations correlate negatively (and strongly - $\mathrm{R}=0.833$ ) with $\mathrm{Mg \#}$. $\mathrm{TiO}_{2}$ concentrations of ironrich SVC amphiboles are greater, by up to 1 wt\%, than previously reported Aleutian amphiboles, and $\mathrm{TiO}_{2}$ concentrations at the magnesian end of the SVC array are higher than most other Aleutian amphiboles. $\mathrm{TiO}_{2}$ concentrations of SVC lavas are not, however high with respect to other Aleutian magmas. The significance of the $\mathrm{TiO}_{2}$ concentrations is unclear, but the negative correlation with Mg\# is not expected during falling temperature during magma crystallization. A lack of correlation of $\mathrm{TiO}_{2}$ with the temperature indicators (alkalies and $\mathrm{Al}^{\mathrm{IV}}$ ), confirms that SVC $\mathrm{TiO}_{2}$ systematics are not temperature related. The $\mathrm{TiO}_{2}$ increase may be related to closed system crystallization of a single batch of magma, although the $\mathrm{TiO}_{2}$ variation of over a factor of two would probably require substantial amounts of crystallization. Alternatively, the $\mathrm{TiO}_{2}$ variations may reflect, in some as yet unspecified way, competition for $\mathrm{TI}$ between amphibole and an oxide phase. 
Finally, SVC amphiboles are of very constant composition regardless of the composition of the surrounding magma (unlike the Augustine amphiboles of Daley, 1986). This suggests that all the pargasite crystals had a similar origin, and the high $\mathrm{Na}+\mathrm{K}, \mathrm{Al} \mathrm{IV}$, and $\mathrm{Al}_{2} \mathrm{O}_{3}$ suggest that the magma that crystallized them was at high $T$ and moderate $P$. It seems most likely that the amphibole crystallized from the mafic crater Peak and proto-crater Peak magmas, and was then mixed into the silicic Mt. Spurr magmas immediately prior to eruption.

\section{spinel}

There are two main types of magmatic spinels within the SVC - titanomagnetite and $\mathrm{Fe}^{3+}$-rich cr-spinel. The titanomagnetite occurs in most samples and consists of phenocrysts and microphenocrysts and as inclusions in pyroxenes.

The Cr-spinel, in contrast, occurs only as well formed octahedra included in olivine. Compositions of the Cr-spinels are listed in Appendix VIII. The less evolved spinels (those with highest Mg\#) are characterized by 30-35\% $\mathrm{Cr}_{2} \mathrm{O}_{3}, 20-25 \%$ $\mathrm{Al}_{2} \mathrm{O}_{3}$, and 15-20\% $\mathrm{Fe}_{2} \mathrm{O}_{3}$. With decreasing $\mathrm{Mg \# ,} \mathrm{Al} /\left(\mathrm{Al}+\mathrm{Cr}+\mathrm{Fe}^{3+}\right)$ decreases and $\mathrm{Fe}^{3+} /\left(\mathrm{Al}+\mathrm{Cr}+\mathrm{Fe}^{3+}\right)$ increases (Figure 16). $\mathrm{Cr} /(\mathrm{Cr}+\mathrm{Al})$ variation as $\mathrm{Mg \#}$ decreases is more complicated. In sample OFT-BO7 (one of the mafic ancestral Mt. Spurr samples) $\mathrm{Cr} /(\mathrm{Cr}+\mathrm{Al})$ increases dramatically as Mg\# drops, which presumably reflects change of spinel composition with successive crystalization. Note that the high $\mathrm{Cr} /(\mathrm{Cr}+\mathrm{Al})$ spinels are preserved in the rim of the olivine studied, while the high $\mathrm{Al} /\left(\mathrm{Al}+\mathrm{Cr}+\mathrm{Fe}^{3+}\right)$ spinels are preserved in the core. Because $A$ s solubility in spinel is a function of pressure, this trend in spinel composition is probably produced by crystallization during ascent of the magma body. spinels in acid andesite from Mt. Spurr have low $\mathrm{Cr} /(\mathrm{Cr}+\mathrm{Al})$, low Mg\#, and Fe. This may reflect protracted crystallization, and hence removal of $\mathrm{Cr}$ from the liquid, at moderate pressures. 


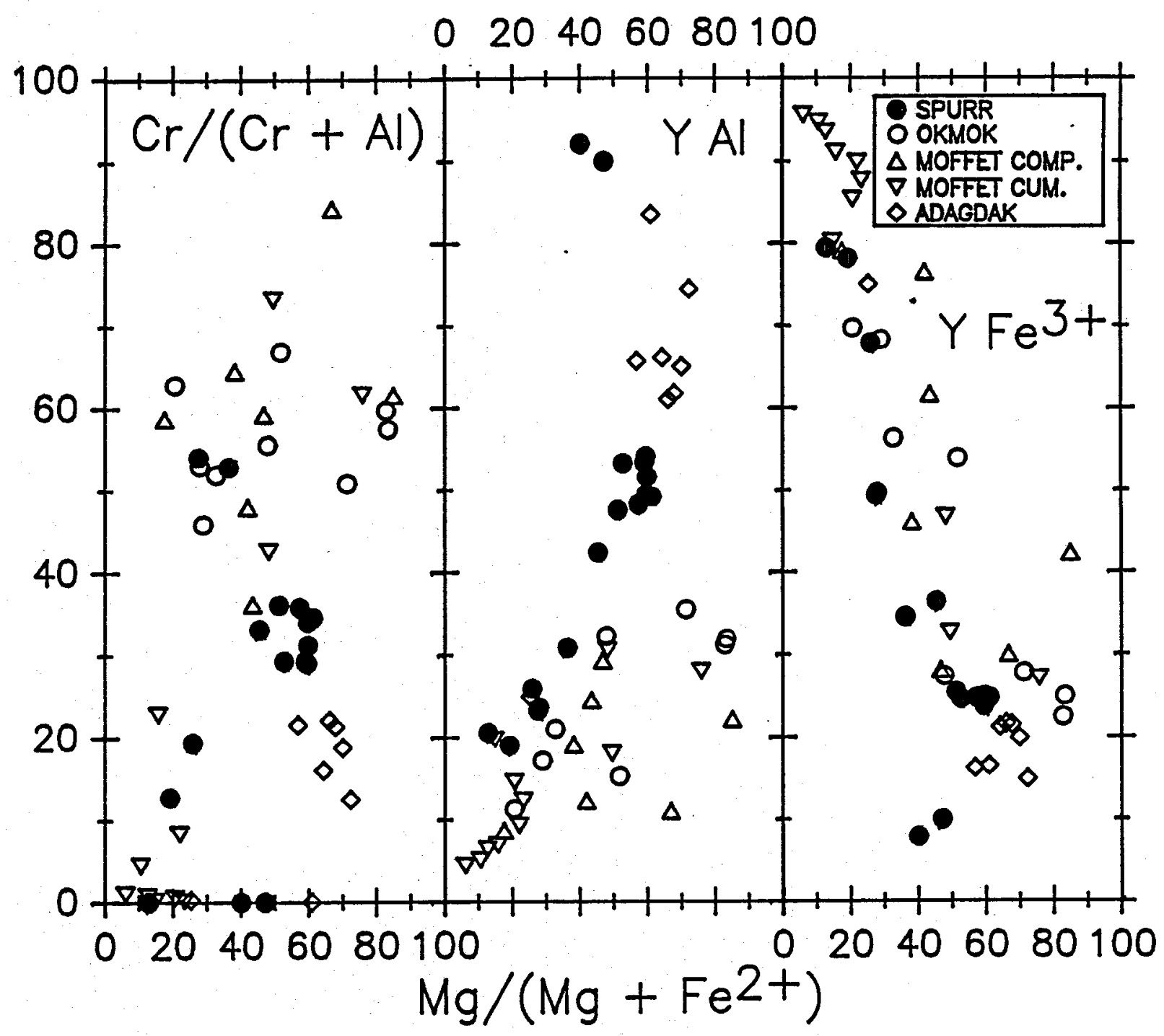

Figure 16. $C_{\frac{F}{3}} /(\mathrm{Cr}+\mathrm{Al}), \mathrm{YAl}\left(\mathrm{Al} /\left(\mathrm{Al}+\mathrm{Cr}+\mathrm{Fe}^{3+}\right)\right)$, and $\mathrm{YFe}$ $\left(\mathrm{Fe}^{3+} /\left(\mathrm{Al}+\mathrm{Cr}+\mathrm{Fe}^{3+}\right)\right)$ Vs. $\mathrm{Mg} \#$ for SVC spinels and other Aleutian spinels from Nye and Reid (1986), DeBari et al. (1986), and Conrad and Kay (1984). 
Compositions of refractory svc spinels fall within the spectrum of previously described Aleutian spinels but are notable in that they have $\mathrm{Cr} /(\mathrm{Cr}+\mathrm{Al}), \mathrm{Al} /\left(\mathrm{Al}+\mathrm{Cr}+\mathrm{Fe}^{3+}\right)$ and $\mathrm{Al}_{2} \mathrm{O}_{3}$ contents intermediate between plagioclase-bearing (thus relatively low pressure) and plagioclase-free, Al-spinelbearing (thus relatively high pressure) xenoliths (Figure 16 and references therein). SVC spinels are also more aluminous than those included in olivine phenocrysts from okmok, a tholeiitic volcano from the central Aleutians. The aluminous nature of refractory SVC spinels, and the fact that $\mathrm{Al} /\left(\mathrm{Al}+\mathrm{Cr}+\mathrm{Fe}^{3+}\right)$ is higher than low-pressure spinels for all Mg\#s, probably reflects moderate to high initial pressure of crystallization and moderate pressure of crystallization of derivative liquids, at the svc. In this sense, the implications of spinel composition are similar to the implications of amphibole composition discussed previously.

\section{Crystal clots}

Clots of crystals occur in samples of lavas from protocrater Peak, the pyroclastic fan, and less commonly crater Peak, and even less commonly in the mafic ancestral Mt. Spurr samples. These clots are of three basic lithologies pyroxenite, anorthosite, and plagioclase-hercynite aggregates. Gabbroic clots, which are common in many calcalkaline volcanoes, are rare.

Pyroxenite clots are most frequently orthopyroxenite or clinopyroxenite, less frequently websterite, and even less frequently olivine websterite. clots with primary lherzolitic lithology have not been found. clots attain maximum diameters of only a few centimeters, and are composed of tightly interlocked, coarse, equant, grains. Individual clinopyroxene grains have pronounced oscillatory zoning, although chemical differences between individual zones are small. orthopyroxene grains frequently contain patches (presumably exolved) of clinopyroxene. Pyroxenite clots are frequently surrounded by 
reaction rims of small, equant, olivine grains, which can incorporate interstitial melt as well as other crystals, such as plagioclase. In some cases pyroxenite clots are surrounded by millimeter-sized amphibole crystals whose long axes tangential to the clots.

The field of clinopyroxene composition from the clots overlaps the field of svc phenocryst composition completely, although clot clinopyroxenes are, on average, lower in sio2 and higher in TiO2, Al203, and Na2O than phenocryst pyroxenes. orthopyroxene from clots and megacrysts falls within the range of phenocryst opx compositions but is of restricted Mg\# (7075) and, on average, higher in CaO and wo.

Anorthosite clots are similar in size and shape to the pyroxenite clots and are composed of tightly interlocked, slightly elongated crystals similar in composition to phenocrysts.

The pyroxenite and anorthosite clots together appear to be fragments of a layered mafic/ultramafic body. Crystals within the clots are completely unaltered, which suggests that they are very young. The clots were probably ripped from the floor of a recently crystallized or still active magma chamber.

Plagioclase-hercynite clots are extremely corroded, rounded clots composed of primary plagioclase with disseminated hercynite crystals throughout. The hercynite appears to be produced during breakdown of the plagioclase. These clots may be crustal xenoliths that are being digested by the magma or may be older anorthosite clots. plagioclase-hercynite clots are much more uncommon than anorthosite clots. There is no petrographic gradation between the plag-hercynite clots and anorthosite clots. 


\section{BYNTHESIS AND INTERPRETATION}

For most of the lifetime of the Spurr Volcanic Complex high silica magmas of uniform composition were erupted from the ancestral Mt. Spurr stratovolcano. K-Ar ages of Turner and Nye (1986) indicate that such andesite production occurred over the interval of slightly more than 0.255 Ma to slightly less than $0.058 \mathrm{Ma}$. Andesite production was periodically interrupted by the injection of new, mafic, magma, and resultant eruptions of more mafic andesites. Intervals between resupply were a minimum of 50,000 years, which is the interval between eruption of anomalously mafic material (Figure 3; Turner and Nye, unpublished $\mathrm{K}-\mathrm{Ar}$ ages). Note that this is a minimum estimate since other mafic flows may not have been sampled.

The building of ancestral Mt. Spurr ended by avalanche caldera formation sometime before 7,000 years ago (Riehle, 1985), and perhaps before 38,000 years ago (Turner and Nye, unpublished data), but after 58,000 years ago. Magmatism subsequent to caldera formation was of an entirely different nature and reflects simultaneous eruption of two magmas and mixtures thereof. One of the magmas was more silicic than anything previously erupted, and one more mafic. The silicic magma is preserved as ashflow(s) resting on top of the debris avalanche and as the present Mt. Spurr. The mafic magma forms proto-Crater Peak and crater Peak. The pyroclastic fan south of Crater Peak is a mixture of the two magmas. Eruption of silicic material ended around 5,000 years ago (Riehle, 1985). Since then mafic material has been erupted from crater Peak. The chamber feeding Crater Peak is at a minimum depth of 23 $\mathrm{km}$, as shown by the aluminum content of hornblende contained in ejecta from the 1953 eruption.

The geological history is consistent with a scenario in which for the bulk of the lifetime of the volcano magma is supplied to the surface from a periodically reinjected mid- 
crustal or lower crustal magma chamber. Protracted crystallization (accompanied by crustal contamination) resulted in a chamber mostly filled with layered pyroxenite and anorthosite overlain by atypically silicic magma. This chamber was injected by new mafic material from depth resulting in a stratified chamber with mafic magma overlain by cumulate debris overlain by silicic magma. There was mixing between the basalt and the crystal debris and the basaltcrystal mixture and the silicic magma. The injection and mixing process destabilized the chamber and it vented to the surface to produce the ashflow(s), Mt. Spurr, the pyroclastic apron, and proto-crater Peak. The mechanism of mixing and ascent must have been complex because all three units were coeruptive. The mixing-exuption event must have removed all of the silicic magma, because none has erupted in the last 5,000 years (Riehle, 1985). Crater Peak lavas have much less crystal debris than proto-Crater Peak lavas.

The location of the magma chamber, and the depth from which Holocene magmas rise is constrained by the aluminum concentration of the most aluminous hornblende to be at least $25 \mathrm{~km}$ deep (see previous discussion of hornblende chemistry). The aluminous nature of spinel inclusions in olivine also suggest derivation from moderate depths.

The above scenario is the simplest description of the history of the SVC. Certain aspects of the chemistry require that fine-scale details are considerably more complex. The large variation in $\mathrm{Rb}, \mathrm{Zr}$, and $\mathrm{K}$ at constant $\mathrm{siO}_{2}$, decoupled major elements (e.g. decreasing $\mathrm{sio}_{2}$ with increasing $\mathrm{K}_{2} \mathrm{O}$ ) in proto-crater peak lavas, and the mafic-felsic-mafic trend in Crater Peak lavas cannot be produced during the mixing and crystal accumulation event described above. This suggests either that the mafic magma was added in at least a few different batches of different composition, that some magma body was in chemical disequilibrium, or that some other component (such as a crustal melt) was added during eruption 
or near enough to the time of eruption that homogenization could not occur.

At a given $\mathrm{SiO}_{2}$ ancestral Mt. Spurr lavas have slightly higher incompatible element concentrations than post-caldera units. This suggests some fundamental shift in either parent magma composition or petrogenetic processes at the time of caldera collapse.

Certain aspects of major and trace element geochemistry are not consistent with an evolutionary mechanism dominated by crystal fractionation. SVC lavas are displaced from dry and water undersaturated low to moderate pressure cotectics in the direction away from normative DI. Olivine plus plagioclase crystallization of such magmas would drive their composition back towards the cotectic. Instead, the svc magmas form a broad band parallel to the cotectic extending toward SI. As discussed by Grove et al. (1982), this suggests the mixing with a silicic crustal component or partial melt thereof. Also, the lack of increase of $\mathrm{Y}$ and $\mathrm{Nb}$ concentrations with increasing $\mathrm{SiO}_{2}$ is inconsistent with fractional crystalization and suggests mixing with a low $\mathrm{Y}$, low $\mathrm{Nb}$, end member. It is not possible to specify what the silicic mixing end member is, or if it is liquid or solid, without determination of the isotopic composition of svc lavas and trace element and isotopic composition of possible crustal end members. The information at hand suggests assimilation of continental sediments or partial melts of McKinley granites rather than bulk assimilation of the granites.

It seems most likely that contamination happened as the magmas were residing in their mid-crustal magma chambers. 


\section{IMPLICATIONS FOR GEOTHERMAL RESOURCES}

of critical interest to geothermal exploration at Mt. Spurr is the question of whether there is a large, shallow, magma chamber supplying heat to the geothermal system, or if there has been such a magma chamber recently enough to significantly increase the local geothermal gradient. As summarized above, for the past 5,000 years volcanism at the SVC has been dominated by eruptions of basaltic andesite which are newly arrived from depths of at least $25 \mathrm{~km}$. These magmas have not had sufficient shallow residence time for hornblende to dissolve, in fact, hornblende in the 1953 ejecta does not even have reaction rims. This suggests pre-eruption residence time on the order of years, at most. Not all of the magma which comes to the surface in any eruptive cycle need erupt, however, so the possibility that some mafic magma remains near the surface as a result of the 1953 eruption cannot be discounted. In many volcanoes a significant fraction of all available magma erupts. Since the 1953 eruption was only of moderate size relatively little magma probably remains near the surface, perhaps on the order of $10^{-2} \mathrm{~km}^{3}$.

During and after caldera formation there was a relatively large body of high-silica andesite which ultimately erupted to form the Mt. Spurr dome. By virtue of its higher silica content this magma was less dense than other SVC magma, and thus may have resided at more shallow depths. In early Holocene time there was apparently extensive hybridization between the silicic magma and the deeply derived mafic magma. These hybrid magmas form the pyroclastic fan. The fact that hybrid magmas have not erupted during the last 5,000 years indicates that the (potentially) shallow body has either crystallized or erupted or been effectively isolated from the plumbing system by which mafic magmas reach the surface. The most straightforward interpretation is that the lack of eruptive products of a shallow silicic body means that there is no such body. 
While the volcanic history suggests that there is not a large, shallow, silicic magma chamber, enough heat must somehow be being supplied to the volcanic edifice to produce the hot springs and fumeroles that exist on the surface. These include the crater Peak fumerole field, the field of steaming ground and diffuse fumeroles on Mt. Spurr, and the zone of warm springs at the base of crater Peak. There is presumably also enough geothermal heat being provided to account for the soil $\mathrm{Hg}$ and He anomalies.

The chemistry of the geothermal fluids is discussed in Appendix IX. The waters from the warm springs appear to be a mixture of waters from diverse sources causing interpretation of chemical geothermometers to be problematic. The fumarole gases, on the other hand, contain chemical information suggesting a reservoir temperature on the order of $200^{\circ} \mathrm{C}$. The heat driving these geothermal phenomena may be derived from either residual magma from the 1953 eruption, from residual heat from the emplacement of the Mt. Spurr dome, or both.

Geophysical and geochemical data of Turner and Wescott (1986) have described a subsurface layer with very low resistivity which they suggest may be a geothermal aquifer. This layer coincides with positive surface $\mathrm{Hg}$ and He anomalies and self potential anomalies. The concordance of geophysical and geochemical anomalies provides evidence that the subsurface layer is a geothermal aquifer. However, the apparent lack of a shallow magmatic body to provide heat to such an aquifer, and the apparent absence of any magma body in the upper $25 \mathrm{~km}$ of crust provides reason to find an alternative explanation for the low resistivity layer. This layer may, then, be one of the large (up to a few tens of meters thick) ashflow-tuffs associated with the Tertiary sediments immediately to the east of the sVC. These ashflows are extensively altered to clays, and are presumably excellent electrical conductors. The low-resistivity layer is structurally similar to the Tertiary sediments immediately 
east of Straight Creek Glacier (Barnes, 1966) in that it dips southward near the projection of the normal fault on Figure 1 and then flattens out south of the fault projection.

\section{ACKNOWLEDGEMENTS}

Financial support was provided by the U.S. Department of Energy Grant No. DE-FG07-84ID12471 to the Alaska Division of Geological and Geophysical surveys and RSA 1070055 from the Alaska Division of Geological and Geophysical surveys to the Geophysical Institute, University of Alaska Fairbanks. Discussions of the field geology with J.E. Beget are gratefully acknowledged, as is field assistance by E.E. Daley and G.D. March. Carl Tobin and David Bratt collected the "SP" rock samples from the 10,000 foot level on Mt. Spurr. B. Farris was primarily responsible for determination of whole rock geochemistry, her expertise with XRF anaysis is very much appreciated. The openness with which J.R. Riehle shared his knowledge of Spurr volcanic stratigraphy and geology is especially appreciated. 


\section{REFERENCES}

Baker, D.R., and Eggler, D.H., 1983, Fractionation paths of Atka (Aleutians) high-alumina basalts: constraints from phase relations: Journal of volcanology and Geothermal Research, v. 18, p. 387-404.

Baker, D.R., and Eggler, D.H., 1987, Compositions of anhydrous and hydrous melts coexisting with plagioclase, augite, and olivine or low-Ca pyroxene from 1 atm to 8 kbar: application to the Aleutian volcanic center of Atka: American Mineralogist, v. 72, p. 12-28.

Barnes, D.F., 1977a, Gravity map of the eastern part of southern Alaska: U.S. Geological survey open-File Report 77-169-c, 1 sheet, scale 1:1,000,000.

Barnes, D.F., 1977b, Gravity map of the western part of southern Alaska: U.S. Geological Survey Open-File Report 77-796-c, 1 sheet, scale 1:1,000,000.

Barnes, F.F., 1966, Geology and coal resources of the BelugaYentna region, Alaska: U.S. Geological Survey Bulletin 1202-C, 54 p., 7 plates.

Bender, J.F., Hodges, F.N., and Bence, A.E., 1978, Petrogenesis of basalts from the project FAMOUS area: experimental study from 0 to 15 kilobars: Earth and Planetary Science Letters, v. 41, p. 277-302.

Biswas, N.N., 1973, P-wave travel-time anomalies: AleutianAlaska region: Tectonophysics v. 19, p. 361-371.

Brophy, J.G., 1986, The Cold Bay volcanic center, Aleutian volcanic arc: I. implications for the origin of hi-alumina arc basalt: contributions to Mineralogy and Petrology, v.93. p. $368-380$.

Brophy, J.G., and Marsh, B.D., 1986, on the origin of highalumina arc basalt and the mechanics of melt extraction: Journal of Petrology, v. 27, p. 763-789.

Capps, S.R., 1929, The Mount Spurr region, Alaska: U.S. Geological Survey Bulletin 810-c pp. 140-172.

Chou, I.-M., 1978, Calibration of oxygen buffers at elevated $P$ and $T$ using the hydrogen fugacity sensor: American Mineralogist, v. 63, p. 690-703. 
Circum-Pacific Council for Energy and Mineral Resources, 1981a, Plate-tectonic map of the circum-Pacific region northeast quadrant: American Association of Petroleum Geology, Tulsa Oklahoma, 1 sheet, scale 1:10,000,000.

Circum-Pacific Council for Energy and Mineral Resources, $1981 \mathrm{~b}$, Plate-tectonic map of the circum-Pacific region northwest quadrant: American Association of Petroleum Geology, Tulsa Oklahoma, 1 sheet, scale 1:10,000,000.

Coe, R.S., Globerman, B.R., Plumley, P.W., and Thrupp, G.A., 1985, Paleomagnetic results from Alaska and their tectonic implications: in Howell, DG, ed., Tectonostratigraphic Terranes of the Circum-Pacific Region: Circum-Pacific Council for Energy and Mineral Resources, Houston TX, USA, p. 85-108.

Conrad, W.K., and Kay, R.W., 1984, Ultramafic and mafic inclusions from Adak Island: crystallization history, and implications for the nature of primary magmas and crustal evolution in the Aleutian Arc: Journal of Petrology, v. 25, p. 88-125.

Cross, T.A., and Pilger, R.H. Jr., 1982, Controls of subduction geometry, location of magmatic arcs, and tectonics of arc and back-arc regions: Geological society of America Bulletin, v. 93, p. 545-562.

Daley, E.E., 1986, Petrology, geochemistry, and the evolution of magmas from Augustine Volcano, Alaska: Univ. of Alaska Fairbanks unpub. MS thesis, $106 \mathrm{pp}$.

DeBari, S., Kay, S.M., and Kay, R.W., 1987, Ultramafic xenoliths from Adagdak Volcano, Adak, Aleutian Islands, Alaska: deformed igneous cumulates from the moho of an island arc: Journal of Geology, v. 95, p. 329-341.

Detterman, R.L., Allaway, W.H. Jr, O'Leary, R.M., Gruzenski, A.L., Hurrell, J.T., and Risoli, D.A., 1980, Sample location map and analytical data for rock samples collected in 1979, Ugashik and Karluk quadrangles, Alaska: U.S. Geological survey Open-File Report 80-142.

Drake, M.J., 1976, Plagioclase-melt equilibria: Geochimica et Cosmochimica Acta, v. 40, p. 457-465.

Engebretson, D.C., Cox, A., and Gordon, R.G., 1985, Relative motions between oceanic and continental plates in the Pacific Basin: Geological Society of America Special Paper $206,59 \mathrm{pp}$. 
Ewart, A., 1982, The mineralogy and petrology of TertiaryRecent orogenic volcanic rocks: with special reference to the andesitic-basaltic compositional range, in Thorpe R.S., ed., Andesites: Orogenic Andesites and Related Rocks, John Wiley and Sons, New York, pp. 25-95.

Ford, C.E., Russell, D.G., Craven, J.A., and Fisk, M.R., 1983, Olivine-liquid equilibria: temperature, pressure and composition dependence of the crystal/liquid cation partition coefficients for $\mathrm{Mg}, \mathrm{Fe}+, \mathrm{Ca}$ and $\mathrm{Mn}$ : Journal of Petrology, v. 24, p. 256-265.

Fujimaki, H., and Tatsumoto, M., 1984, Partition coefficients of Hf, $\mathrm{Zr}$, and REE between phenocrysts and liquid, In, Proceedings of the Fourteenth Lunar and Planetary science Conference, Part 2: Journal of Geophysical Research, v. 89 supplement, p. B662-B772.

Gill, J.B., 1981, Orogenic Andesites and Plate Tectonics. Springer-Verlag, New York, $390 \mathrm{pp}$.

Green, D.H., and Ringwood, A.E., 1967, The genesis of basaltic magmas: Contributions to Mineralogy and Petrology, v. 15, p. 103-190.

Green, D.H., Ringwood, A.E., Hibberson, W.O., and Ware, W.C., 1975, Experimental petrology of Apollo 17 mare basalts: Proceedings of the 6th Lunar science Conference, p. 871893.

Green, T.H., and Pearson, N.J., 1987, An experimental study of $\mathrm{Nb}$ and $\mathrm{Ta}$ partitioning between Ti-rich minerals and silicate liquids at high pressure and temperature: Geochimica et Cosmochimica Acta, v. 51, p. 55-62.

Grove, T.L., and Bryan, W.B., 1983, Fractionation of pyroxene phyric MORB at low pressure: an experimental study: Contributions to Mineralogy and Petrology, v. 84, p. 293309.

Grove, T.I., Gerlach, D.C., and Sando, T.W., 1982, Origin of calc-alkaline series lavas at Medicine Lake Volcano by fractionation, assimilation and mixing: Contributions to Mineralogy and Petrology, v. 80, p. 160-182.

Gust, D.A., and Perfit, M.R., 1987, Phase relations of a highMg basalt from the Aleutian Island Arc: implications for primary island arc basalts and high-Al basalts: Contributions to Mineralogy and Petrology, v. 97, p. 7-18.

Hammarstrom, J.M., and Zen, E, 1986, Aluminum in hornblende: an empirical igneous geobarometer: American Mineralogist, v. 71, p. 1297-1313. 
Hawthorne, F.C., 1981, Crystal chemistry of the amphiboles, in Veblen D.R., ed., Amphiboles and other Hydrous Pyriboles Mineralogy: Mineralogical Society of America Reviews in MineralogY V. 9A, pp. 1-102.

Helz, R.T., 1976, Phase relations of basalts in their melting ranges at $\mathrm{PH}_{2} \mathrm{O}=5 \mathrm{~kb}$, Part II: melt compositions: Journal of Petrology, v. 17, p. 139-193.

Hollister, L.S., Grissom, G.C., Peters, E.K., stowell, H.H., and Sisson, V.B., 1987, Conformation of the empirical correlation of Al in hornblende with pressure of solidification of calc-alkaline plutons: American Mineralogist, v. 72, p. 231-239.

Jacob, K.H., Nakamura, K., and Davies, J.N., 1977, Trenchvolcano gap along the Alaska-Aleutian arc: facts, and speculations on the role of terrigenous sediments: in Talwani, M., and Pitman, W.C., Island Arcs, Deep sea Trenches, and Back-arc Basins, American Geophysical Union, Washington, D.C., 243-258.

Johnston; A.D., 1986, Anhydrous P-T phase relations of nearprimary high-alumina basalt from the south sandwich Islands: implications for the origin of island arcs and tonalite-trondhjemite series rocks: contributions to Mineralogy and Petrology, v. 92, p. 368-382.

Jones, D.L., Silberling, H.J., Berg, H.C., and Plafker, G., 1981, Map showing tectonostratigraphic terranes of Alaska, columnar sections, and summary description of terranes: U.S. Geological survey Open-File Report $81-792,20$ pp., 2 plates.

Juhle, W., and Coulter, H., 1955, The Mt. Spurr eruption, July 9. 1953: Transactions, American Geophysical Union, v. 36, p. 199-202.

Kay, S.M., and Kay, R.W., 1985, Aleutian tholeiitic and calcalkaline magma series I: the mafic phenocrysts: Contributions to Mineralogy and Petrology, v. 90, p. 276290.

Kay, S.M., Kay, R.W., and citron, G.P., 1982, Tectonic controls on tholeitic and calc-alkaline magmatism in the Aleutian Arc: Journal of Geophysical Research, v. 87, p. 4051-4072.

Kienle, J., Swanson, S.E., and Pulpan, H., 1983, Magmatism and subduction in the eastern Aleutian Arc; in, Shimozuru D., and Yokoyama, I., eds., Arc Volcanism: Physics and Tectonics. Terra scientific Publishing Co. Tokyo, Japan, pp. 191-224. 
Lanphere, M.A., and Reed, B.L., 1985, The Mckinley sequence of granitic rocks: a key element in the accretionary history of southern Alaska: Journal of Geophysical Research, $v$. 90 , p. $11,413-11,430$.

Leake, B.E., 1978, Nomenclature of amphiboles: Canadian Mineralogist, v. 16, p. 501-520.

leMaitre, R.W., 1979, A new generalized petrologic mixing model: Contributions to Mineralogy and Petrology, v. 71, p. 133-137.

Lindsley, D.H., 1983, Pyroxene thermometry: American Mineralogist, v. 68, p. 477-493.

Longhi, J., Walker, D., and Hays, J.F., 1978, The distribution of $\mathrm{Fe}$ and $\mathrm{Mg}$ between olivine and Iunar basaltic liquids: Geochimica et Cosmochimica Acta, v. 42, p. 1545-1558.

Magoon, L.B., Adkinson, W.L., and Egbert, R.M., 1976, Map showing geology, wildcat wells, Tertiary plant fossil localities, K-Ar age dates, and petroleum operations, Cook Inlet Area, Alaska: U.S. Geological Survey Map I-1019, 4 sheets.

Marsh, B.D., 1982, The Aleutians, IN Thorpe, R.S., (ed) Andesites: John Wylie and Sons, New York, p. 99-114.

Myers, J.D., Marsh, B.D., and Sinha, A.K., 1985, strontium isotopic and selected trace element variations between two Aleutian volcanic centers (Adak and Atka): implications for the development of arc volcanic plumbing systems. Contrib. Mineral. Petrol. 91:221-234.

Myers, J.D., Marsh, B.D., and Sinha, A.K., 1986, Geochemical and strontium isotopic characteristics of parental Aleutian arc magmas: evidence from the basaltic lavas of Atka. Contrib. Mineral. Petrol. 94:1-11.

Nye, C.J., and Reid, M.R., 1986, Geochemistry of primary and least fractionated lavas from okmok volcano, central Aleutians: implications for arc magmagenesis: Journal of Geophysical Research, v. 91, p. 10271-10287.

Panuska, B.C., and stone, D.B., 1985, Latitudinal motion of the Wrangellia and Alexander terranes and the southern Alaska Superterrane; in Howell DG, ed., Tectonostratigraphic Terranes of the Circum-Pacific Region: Circum-Pacific Council for Energy and Mineral Resources, Houston TX, USA, 109-120 
Pickthorn, W.J., Yount, M.E., Cooley, E.F., o'Leary, R.M., Detra, D.E., and Ito, G., 1979, Sample location map and analytical data for rock samples collected in 1978, Chignik and Sutwik Island quadrangles, Alaska: U.S. Geological Survey Open-File Report 79-1506, I sheet, scale 1:250,000.

Reed, B.L., and Lanphere, M.A., 1972, Generalized geologic map of the Alaska-Aleutian Range batholith showing potassiumargon ages of the plutonic rocks: U.S. Geological survey Miscellaneous Field Studies Map MF-372, 2 sheets.

Riehle, J.R., 1985, A reconnaissance of the major Holocene tephra deposits in the upper cook Inlet region, Alaska: Journal of Volcanology and Geothermal Research, v. 26, p. 37-74.

Roeder, P.L., 1974, Activity of iron and olivine solubility in basaltic liquids: Earth and Planetary science Letters, $v$. 23 , p. 397-410.

Roeder, P.L., and Emslie, R.F., 1970, Olivine-liquid equilibrium: Contributions to Mineralogy and Petrology, v. 29, p. 275-289.

Sack, R.O., Carmichael, I.S.E., Rivers, M., and Ghiorso, M.S., 1980, Ferric-ferrous equilibria in natural silicate liquids at 1 bar: Contributions to Mineralogy and Petrology, $v$. 75, p. 369-376.

Schmoll, H.R., and Yehle, L.A., 1986, Pleistocene glaciation of the upper cook. Inlet basin. In: Hamilton TD, Reed KM, Thorson RM, eds. Glaciation in Alaska: The Geologic Record: Alaska Geological Society, Anchorage Alaska, pp 193-219.

Stephens, C.D., Fogleman, K.A., Lahr, J.C., and Page, R.A., 1984, Wrangell Benioff zone, southern Alaska: Geology, $v$. 12 , p. $373-376$.

Turner, D.I., and NYe, C.J., 1986, Geochronology of eruptive events at Mt. Spurr, Alaska, in Turner, D $L$, and Wescott, E M, eds., Geothermal energy resource investigations at Mt. Spurr, Alaska: University of Alaska Fairbanks Geophysical Institute Report, UAG R-308, p. 2-1 to 2-7.

Turner, D.L., Nye, C.J., Beget, J.E., and Wescott, E.M., 1986, The Mt. Spurr, Alaska geothermal energy assessment project: introduction, geologic overview and present geothermal manifestations, in Turner, D $L$, and Wescott, $E$, eds., Geothermal energy resource investigations at $M t$. Spurr, Alaska: University of Alaska Fairbanks Geophysical Institute Report, UAG R-308, p. 1-1 to 1-12, 1 pl., scale $1: 63,360$. 
Turner, D.L., and Wescott, E.M., eds., 1986, Geothermal energy resource investigations at Mt. Spurr, Alaska: University of Alaska Fairbanks Geophysical Institute Report, UAG R308 .

Usselman, T.M., and Lofgren, G.E., 1976, The phase relations, textures, and mineral chemistries of high-titanium mare basalts as a function of oxygen fugacity and cooling rate: Proceedings of the 7 th Lunar Science Conference, $p .1,345-$ 1,363 .

von Huene, R., Keller, G., Bruns, T.R., and McDougall, K., 1985, Cenozoic migration of Alaskan terranes indicated by paleontologic study; in Howell, DG, ed., Tectonostratigraphic Terranes of the circum-Pacific Region: Circum-Pacific Council for Energy and Mineral Resources, Houston TX, USA, 121-136.

Walker, D., Shibata, T., and DeLong, S.E., 1979, Abyssal tholeites from the oceanographer fracture zone II. Phase equilibria and mixing: Contributions to Mineralogy and Petrology, v. 70, p. 111-125.

Wescott, E.M., Witte, W., Moore, P., and Echelmeyer, K., 1986, Ice thickness measurements in the basin surrounding the summit of Mt. Spurr, Alaska, in Turner, D. L., and Wescott, E. M., eds., Geothermal energy resource investigations at Mt. Spurr, Alaska: University of Alaska Fairbanks Geophysical Institute Report, UAG R-308, p. 3-1 to 3-13.

Wilson, F.H., Detterman, R.L., and Case, J.E., 1985, The Alaska Peninsula terrane; a definition: U.S. Geological Survey Open-File Report 85-450, 17 pp.

Yount, M.E., Cooley, E.F., and O'Leary, R.M., 1978, Sample location map, analytical data, and statistical summary of analyses of rock samples, Chignik and Sutwik Island quadrangles, Alaska: U.S. Geological survey Open-File Report 78-557, 1 sheet, scale 1:250,000. 


\section{APPENDIX I - Whole-rock chemistry and point-count data}

Whole rock chemistry was determined by analyzing all samples in duplicate on the Alaska Division of Geological and Geophysical Surveys fully automated Rigaku 3064 spectrometer. Data reduction software was modified from that developed for the Rigaku 3064 at New Mexico Tech by B. Farris.

Major element concentrations were determined on fused pellets fluxed with a $\mathrm{Li}_{2} \mathrm{~B}_{4} \mathrm{O}_{7}-\mathrm{LiCO}_{3}-\mathrm{La}_{2} \mathrm{O}_{3}$ mixture. Mean analytical precision of duplicate fusions of single samples (1 st. dev./mean) is between 0.2 and $0.7 \%$ (or $0.01 \mathrm{wt.} \%$ ) except for Na20, which is less than $3 \%$.

Trace element concentrations were determined on boric acidbacked pressed powder pellets bound with polyvinylalcohol. Trace element determinations have mean analytical precision of better than $1 \%$ relative or $0.5 \mathrm{ppm}$, with the exception of $\mathrm{Ni}$, for which precision is better than $2 \mathrm{ppm}$ at concentrations of 10 to $50 \mathrm{ppm}$.

Analytical results compare extremely favorably with analyses of the same unknowns by isotope dilution, atomic absorption spectrometry, instrumental neutron activation analysis and XRF spectrometry at MIT, UC santa Cruz and the Memorial University, Newfoundland. These comparisons, together with analyses of known compositions, indicate that whole rock data are accurate to better than $2 \%$ relative for major elements, and 5\% relative, or a few ppm, for trace elements.

Modes were determined by counting 300 points on single thin sections from each sample. 
Spurr Volcanic Complex whole rock data, major elements normal ized anhydrous

strat\# AMS-26 AMS-B01 AMS-B02 AMS-BO3 AMS-B04 AMS-B05 AMS-BO6 AMS-B07 AMS-B08 AMS-B09 AMS-B10 AMS-A01 AMS-A02 AMS-A03 AMS-A04

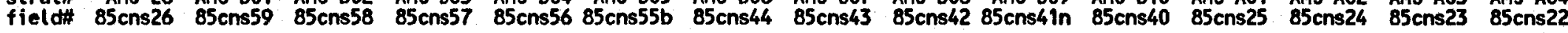

\begin{tabular}{|c|c|c|c|c|c|c|c|c|c|c|c|c|c|c|c|c|}
\hline & $\begin{array}{r}\mathrm{si02} \\
\mathrm{Ti02} \\
\mathrm{Al} 203 \\
\mathrm{Fez203} \\
\mathrm{MnO} \\
\mathrm{MgO} \\
\mathrm{CaO} \\
\mathrm{MazO} \\
\mathrm{K} 20 \\
\mathrm{P205}\end{array}$ & $\begin{array}{r}53.90 \\
0.97 \\
17.29 \\
8.52 \\
0.14 \\
5.24 \\
9.30 \\
3.03 \\
1.40 \\
0.21\end{array}$ & $\begin{array}{r}59.12 \\
0.69 \\
16.79 \\
6.71 \\
0.12 \\
4.78 \\
6.57 \\
3.38 \\
1.66 \\
0.19\end{array}$ & $\begin{array}{r}58.01 \\
0.83 \\
18.61 \\
7.10 \\
0.12 \\
3.46 \\
6.94 \\
3.29 \\
1.42 \\
0.22\end{array}$ & $\begin{array}{r}59.52 \\
0.70 \\
16.95 \\
6.58 \\
0.11 \\
4.17 \\
6.46 \\
3.61 \\
1.72 \\
0.19\end{array}$ & $\begin{array}{r}58.06 \\
0.76 \\
17.61 \\
7.08 \\
0.12 \\
4.20 \\
7.11 \\
3.33 \\
1.54 \\
0.20\end{array}$ & $\begin{array}{r}59.43 \\
0.79 \\
17.33 \\
6.77 \\
0.11 \\
3.50 \\
6.47 \\
3.63 \\
1.75 \\
0.22\end{array}$ & $\begin{array}{r}59.60 \\
0.79 \\
18.11 \\
6.41 \\
0.11 \\
2.97 \\
6.31 \\
3.76 \\
1.70 \\
0.24\end{array}$ & $\begin{array}{r}53.13 \\
0.88 \\
17.02 \\
8.66 \\
0.14 \\
7.20 \\
8.49 \\
3.31 \\
0.96 \\
0.21\end{array}$ & $\begin{array}{r}56.19 \\
1.00 \\
18.83 \\
7.25 \\
0.13 \\
3.38 \\
8.17 \\
3.56 \\
1.25 \\
0.25\end{array}$ & $\begin{array}{r}59.50 \\
0.80 \\
18.09 \\
6.48 \\
0.12 \\
3.02 \\
6.27 \\
3.79 \\
1.69 \\
0.24\end{array}$ & $\begin{array}{r}58.46 \\
0.76 \\
18.26 \\
7.09 \\
0.12 \\
3.39 \\
6.66 \\
3.64 \\
1.39 \\
0.24\end{array}$ & $\begin{array}{r}59.57 \\
0.71 \\
17.32 \\
6.70 \\
0.12 \\
3.44 \\
6.56 \\
3.63 \\
1.74 \\
0.20\end{array}$ & $\begin{array}{r}59.56 \\
0.73 \\
17.33 \\
6.78 \\
0.13 \\
3.50 \\
6.64 \\
3.43 \\
1.70 \\
0.20\end{array}$ & $\begin{array}{r}59.91 \\
0.72 \\
17.37 \\
6.64 \\
0.13 \\
3.11 \\
6.65 \\
3.53 \\
1.74 \\
0.20\end{array}$ & $\begin{array}{r}51.28 \\
1.07 \\
17.94 \\
9.37 \\
0.16 \\
6.01 \\
10.30 \\
2.92 \\
0.71 \\
0.24\end{array}$ \\
\hline & $\begin{array}{r}\text { LOI } \\
\text { TOTAL }\end{array}$ & $\begin{array}{r}1.25 \\
100.07\end{array}$ & $\begin{array}{r}-0.09 \\
100.54\end{array}$ & $\begin{array}{r}-0.16 \\
100.28\end{array}$ & $\begin{array}{r}-0.09 \\
100.03\end{array}$ & $\begin{array}{r}-0.14 \\
100.61\end{array}$ & $\begin{array}{r}-0.11 \\
99.86\end{array}$ & $\begin{array}{r}0.58 \\
100.10\end{array}$ & $\begin{array}{c}-0.24 \\
99.66\end{array}$ & $\begin{array}{r}0.17 \\
100.48\end{array}$ & $\begin{array}{r}0.63 \\
100.36\end{array}$ & $\begin{array}{r}-0.19 \\
100.33\end{array}$ & $\begin{array}{r}-0.15 \\
100.40\end{array}$ & $\begin{array}{r}-0.16 \\
100.38\end{array}$ & $\begin{array}{l}-0.17 \\
99.82\end{array}$ & $\begin{array}{r}-0.26 \\
100.77\end{array}$ \\
\hline $\begin{array}{r}\text { FMQ } \\
N N O \\
\text { NNO+1 }\end{array}$ & $\begin{array}{r}\mathrm{CaO} / \mathrm{Atz} 203 \\
\mathrm{FeOt} / \mathrm{MgO} \\
\mathrm{FeO} / \mathrm{MgO} \\
\mathrm{FeO} / \mathrm{MgO} \\
\mathrm{FeO} / \mathrm{MgO}\end{array}$ & $\begin{array}{l}0.54 \\
1.46 \\
1.24 \\
1.17 \\
1.03\end{array}$ & $\begin{array}{l}0.39 \\
1.26 \\
1.06 \\
1.00 \\
0.87\end{array}$ & $\begin{array}{l}0.37 \\
1.84 \\
1.55 \\
1.46 \\
1.29\end{array}$ & $\begin{array}{l}0.38 \\
1.42 \\
1.18 \\
1.11 \\
0.97\end{array}$ & $\begin{array}{l}0.40 \\
1.52 \\
1.27 \\
1.20 \\
1.05\end{array}$ & $\begin{array}{l}0.37 \\
1.74 \\
1.44 \\
1.35 \\
1.18\end{array}$ & $\begin{array}{l}0.35 \\
1.94 \\
1.60 \\
1.51 \\
1.32\end{array}$ & $\begin{array}{l}0.50 \\
1.08 \\
0.93 \\
0.88 \\
0.79\end{array}$ & $\begin{array}{l}0.43 \\
1.93 \\
1.62 \\
1.52 \\
1.34\end{array}$ & $\begin{array}{l}0.35 \\
1.93 \\
1.60 \\
1.50 \\
1.31\end{array}$ & $\begin{array}{l}0.36 \\
1.88 \\
1.57 \\
1.48 \\
1.30\end{array}$ & $\begin{array}{l}0.38 \\
1.75 \\
1.45 \\
1.36 \\
1.19\end{array}$ & $\begin{array}{l}0.38 \\
1.74 \\
1.44 \\
1.36 \\
1.19\end{array}$ & $\begin{array}{l}0.38 \\
1.92 \\
1.58 \\
1.49 \\
1.30\end{array}$ & $\begin{array}{l}0.57 \\
1.40 \\
1.21 \\
1.14 \\
1.02\end{array}$ \\
\hline & $\begin{array}{c}\mathrm{Rb} \\
K \\
\mathbf{S r} \\
\mathbf{Y} \\
\mathbf{2 r} \\
\mathrm{Nb} \\
\mathrm{Ni}\end{array}$ & $\begin{array}{r}28.6 \\
11593 \\
635 \\
18.6 \\
108 \\
6.3 \\
15\end{array}$ & $\begin{array}{r}35.6 \\
1377 \\
498 \\
18.7 \\
135 \\
6.5 \\
26\end{array}$ & $\begin{array}{r}33.0 \\
11819 \\
518 \\
20.1 \\
115 \\
6.7 \\
7\end{array}$ & $\begin{array}{r}38.7 \\
14262 \\
460 \\
20.4 \\
138 \\
6.3 \\
18\end{array}$ & $\begin{array}{r}33.8 \\
12772 \\
504 \\
20.4 \\
120 \\
6.3 \\
14\end{array}$ & $\begin{array}{r}40.1 \\
14541 \\
486 \\
22.1 \\
141 \\
7.1 \\
11\end{array}$ & $\begin{array}{r}39.9 \\
14097 \\
563 \\
19.9 \\
138 \\
7.0 \\
8\end{array}$ & $\begin{array}{r}17.9 \\
7978 \\
473 \\
18.3 \\
82 \\
5.6 \\
38\end{array}$ & $\begin{array}{r}24.1 \\
10345 \\
525 \\
21.0 \\
111 \\
7.5 \\
10\end{array}$ & $\begin{array}{r}39.8 \\
14068 \\
567 \\
19.5 \\
138 \\
7.3 \\
7\end{array}$ & $\begin{array}{r}32.5 \\
11562 \\
507 \\
19.7 \\
117 \\
6.6 \\
9\end{array}$ & $\begin{array}{r}35.6 \\
14448 \\
511 \\
20.4 \\
137 \\
6.6 \\
12\end{array}$ & $\begin{array}{r}35.7 \\
14119 \\
517 \\
20.4 \\
134 \\
6.3 \\
11\end{array}$ & $\begin{array}{r}37.2 \\
14446 \\
510 \\
20.6 \\
135 \\
6.1 \\
10\end{array}$ & $\begin{array}{r}6.3 \\
5916 \\
681 \\
17.5 \\
68 \\
5.5 \\
21\end{array}$ \\
\hline & $\begin{array}{l}K / R b \\
K / Y \\
Z r / Y \\
R b / Z r \\
K / Z r\end{array}$ & $\begin{array}{r}404.9 \\
623.3 \\
5.8 \\
0.264 \\
106.9\end{array}$ & $\begin{array}{r}387.3 \\
735.2 \\
7.2 \\
0.264 \\
102.2\end{array}$ & $\begin{array}{r}358.3 \\
588.9 \\
5.7 \\
0.288 \\
103.2\end{array}$ & $\begin{array}{r}368.1 \\
700.8 \\
6.8 \\
0.282 \\
103.6\end{array}$ & $\begin{array}{r}377.4 \\
624.8 \\
5.9 \\
0.282 \\
106.4\end{array}$ & $\begin{array}{r}362.5 \\
657.2 \\
6.4 \\
0.285 \\
103.5\end{array}$ & $\begin{array}{r}353.3 \\
709.5 \\
6.9 \\
0.290 \\
102.5\end{array}$ & $\begin{array}{r}445.9 \\
435.0 \\
4.5 \\
0.217 \\
96.7\end{array}$ & $\begin{array}{r}430.1 \\
492.9 \\
5.3 \\
0.217 \\
93.3\end{array}$ & $\begin{array}{r}353.5 \\
722.2 \\
7.1 \\
0.289 \\
102.2\end{array}$ & $\begin{array}{r}355.5 \\
588.1 \\
5.9 \\
0.279 \\
99.0\end{array}$ & $\begin{array}{r}405.5 \\
709.3 \\
6.7 \\
0.261 \\
105.8\end{array}$ & $\begin{array}{r}395.2 \\
692.1 \\
6.5 \\
0.267 \\
105.7\end{array}$ & $\begin{array}{r}388.8 \\
702.6 \\
6.6 \\
0.275 \\
107.0\end{array}$ & $\begin{array}{r}937.6 \\
337.7 \\
3.9 \\
0.092 \\
86.6\end{array}$ \\
\hline & $\begin{array}{l}\text { ol } \\
\text { pl } \\
\text { cpx } \\
\text { opx }\end{array}$ & $\begin{array}{r}5.0 \\
12.8 \\
8.0 \\
1.0\end{array}$ & $\begin{array}{r}23.0 \\
5.8 \\
3.5\end{array}$ & $\begin{array}{r}29.8 \\
1.8 \\
8.5\end{array}$ & $\begin{array}{r}33.0 \\
6.0 \\
5.5\end{array}$ & $\begin{array}{r}20.0 \\
5.3 \\
6.0\end{array}$ & $\begin{array}{r}32.3 \\
3.8 \\
5.3\end{array}$ & $\begin{array}{r}33.0 \\
2.5 \\
6.0\end{array}$ & $\begin{array}{l}5.8 \\
8.5 \\
3.3\end{array}$ & $\begin{array}{r}1.3 \\
13.3 \\
1.5\end{array}$ & $\begin{array}{r}27.3 \\
1.0 \\
5.5\end{array}$ & $\begin{array}{r}22.0 \\
2.3 \\
5.0\end{array}$ & $\begin{array}{r}37.8 \\
6.3 \\
6.0\end{array}$ & $\begin{array}{r}33.5 \\
3.8 \\
5.5\end{array}$ & $\begin{array}{r}36.0 \\
8.3 \\
3.8\end{array}$ & $\begin{array}{r}27.3 \\
5.5 \\
4.3\end{array}$ \\
\hline & $\begin{array}{r}\text { mt } \\
\text { gms } \\
\text { notes }\end{array}$ & $\begin{array}{r}0.3 \\
73.0 \\
\text { oalt t }\end{array}$ & $\begin{array}{r}0.5 \\
67.3\end{array}$ & $\begin{array}{r}0.3 \\
59.8\end{array}$ & $\begin{array}{r}0.8 \\
54.8\end{array}$ & $\begin{array}{r}0.3 \\
68.5\end{array}$ & $\begin{array}{r}1.3 \\
57.5\end{array}$ & $\begin{array}{r}0.0 \\
58.5\end{array}$ & 82.5 & 84.0 & 66.3 & $\begin{array}{r}1.0 \\
69.8\end{array}$ & $\begin{array}{r}0.8 \\
49.3\end{array}$ & $\begin{array}{r}2.0 \\
55.3\end{array}$ & $\begin{array}{r}2.3 \\
49.8\end{array}$ & 63.0 \\
\hline
\end{tabular}




\begin{tabular}{|c|c|c|c|c|c|c|c|c|c|c|c|c|c|c|c|c|}
\hline & $\begin{array}{l}\text { strat\# } \\
\text { field\# }\end{array}$ & $\begin{array}{l}\text { AMS-A05 } \\
85 \text { ens } 21\end{array}$ & $\begin{array}{l}\text { AMS-A06 } \\
85 \text { ens } 37\end{array}$ & $\begin{array}{l}\text { AMS-A07 } \\
85 \mathrm{cns} 36\end{array}$ & $\begin{array}{l}\text { AMS-A08 } \\
85 \mathrm{cns} 35\end{array}$ & $\begin{array}{r}\text { AF-06 } \\
85 \mathrm{cns} 06 \mathrm{f}\end{array}$ & $\begin{array}{r}\text { AF-08 } \\
85 \mathrm{cns08}\end{array}$ & $\begin{array}{r}\text { AF -09 } \\
85 \mathrm{cns09}\end{array}$ & $\begin{array}{r}\text { AF- } 50 \\
85 \text { cns30 }\end{array}$ & $\begin{array}{l}\text { S85TRS5 } \\
\text { s85trs5 }\end{array}$ & $\begin{array}{l}\text { SP-01 } \\
\text { P-rs1 }\end{array}$ & $\begin{array}{r}s p-02 \\
s p-r s 2\end{array}$ & $\begin{array}{r}\text { SP-03 } \\
\text { sp-rs3 }\end{array}$ & $\begin{array}{l}\text { SP-04 } \\
\text { sp-rs4 }\end{array}$ & $\begin{array}{r}P F-01 \\
85 \text { cns } 01\end{array}$ & $\begin{array}{r}P F-03 \\
85 \mathrm{cns} 03\end{array}$ \\
\hline & $\begin{array}{r}5102 \\
\mathrm{TiO2} \\
\mathrm{i} 1203 \\
\mathrm{Fe} 203 \\
\mathrm{MnO} \\
\mathrm{Mg0} \\
\mathrm{CaO} \\
\mathrm{Na20} \\
\mathrm{K} 20 \\
\mathrm{P} 205\end{array}$ & $\begin{array}{r}58.15 \\
0.75 \\
17.27 \\
7.14 \\
0.13 \\
3.85 \\
7.26 \\
3.65 \\
1.59 \\
0.21\end{array}$ & $\begin{array}{r}58.23 \\
0.75 \\
17.27 \\
7.09 \\
0.13 \\
3.88 \\
7.24 \\
3.59 \\
1.63 \\
0.21\end{array}$ & $\begin{array}{r}59.41 \\
0.74 \\
17.54 \\
6.69 \\
0.12 \\
3.29 \\
6.72 \\
3.61 \\
1.68 \\
0.20\end{array}$ & $\begin{array}{l}57.46 \\
0.80 \\
18.34 \\
7.20 \\
0.13 \\
3.67 \\
7.44 \\
3.41 \\
1.35 \\
0.21\end{array}$ & $\begin{array}{r}62.55 \\
0.56 \\
17.22 \\
5.49 \\
0.12 \\
2.43 \\
5.61 \\
3.89 \\
1.90 \\
0.22\end{array}$ & $\begin{array}{r}61.42 \\
0.63 \\
17.41 \\
5.89 \\
0.11 \\
2.74 \\
5.90 \\
3.79 \\
1.89 \\
0.21\end{array}$ & $\begin{array}{r}62.45 \\
0.58 \\
16.93 \\
5.33 \\
0.10 \\
2.27 \\
5.47 \\
4.57 \\
2.08 \\
0.20\end{array}$ & $\begin{array}{r}60.72 \\
0.65 \\
17.38 \\
6.01 \\
0.12 \\
3.16 \\
6.33 \\
3.85 \\
1.58 \\
0.21\end{array}$ & $\begin{array}{r}62.75 \\
0.59 \\
16.73 \\
5.43 \\
0.10 \\
2.63 \\
5.50 \\
3.89 \\
2.21 \\
0.18\end{array}$ & $\begin{array}{r}60.93 \\
0.66 \\
17.32 \\
6.61 \\
0.12 \\
2.88 \\
5.84 \\
3.61 \\
1.82 \\
0.21\end{array}$ & $\begin{array}{r}61.89 \\
0.59 \\
17.26 \\
5.77 \\
0.11 \\
2.70 \\
5.69 \\
3.93 \\
1.84 \\
0.21\end{array}$ & $\begin{array}{r}61.76 \\
0.65 \\
17.67 \\
5.60 \\
0.10 \\
2.83 \\
5.79 \\
3.55 \\
1.83 \\
0.21\end{array}$ & $\begin{array}{r}62.84 \\
0.60 \\
16.70 \\
5.75 \\
0.11 \\
2.71 \\
5.67 \\
3.63 \\
1.76 \\
0.24\end{array}$ & $\begin{array}{r}56.65 \\
0.79 \\
17.60 \\
7.32 \\
0.13 \\
4.98 \\
7.33 \\
3.92 \\
1.03 \\
0.24\end{array}$ & $\begin{array}{c}56.21 \\
0.87 \\
17.69 \\
7.81 \\
0.13 \\
4.91 \\
7.81 \\
3.23 \\
1.14 \\
0.20\end{array}$ \\
\hline & $\begin{array}{r}\text { LOI } \\
\text { TOTAL }\end{array}$ & $\begin{array}{r}-0.14 \\
100.41\end{array}$ & $\begin{array}{r}-0.16 \\
100.44\end{array}$ & $\begin{array}{c}-0.21 \\
100.12\end{array}$ & $\begin{array}{l}-0.21 \\
99.98\end{array}$ & $\begin{array}{r}0.79 \\
100.03\end{array}$ & $\begin{array}{r}0.97 \\
99.88\end{array}$ & $\begin{array}{r}0.96 \\
100.34\end{array}$ & $\begin{array}{r}-0.06 \\
100.33\end{array}$ & $\begin{array}{r}0.26 \\
99.56\end{array}$ & $\begin{array}{r}0.57 \\
100.26\end{array}$ & $\begin{array}{r}0.34 \\
100.30\end{array}$ & $\begin{array}{r}1.47 \\
100.03\end{array}$ & $\begin{array}{r}1.37 \\
100.31\end{array}$ & $\begin{array}{r}-0.15 \\
100.53\end{array}$ & $\begin{array}{r}-0.08 \\
100.47\end{array}$ \\
\hline $\begin{array}{c}\text { FMQ } \\
\text { NNO } \\
\text { NO+1 }\end{array}$ & $\begin{array}{r}\mathrm{CaO} / \mathrm{Al} 203 \\
\mathrm{FeOt} / \mathrm{MgO} \\
\mathrm{FeO} / \mathrm{MgO} \\
\mathrm{FeO} / \mathrm{MgO} \\
\mathrm{FeO} / \mathrm{MgO}\end{array}$ & $\begin{array}{l}0.42 \\
1.67 \\
1.39 \\
1.30 \\
1.14\end{array}$ & $\begin{array}{l}0.42 \\
1.65 \\
1.37 \\
1.28 \\
1.12\end{array}$ & $\begin{array}{l}0.38 \\
1.83 \\
1.51 \\
1.42 \\
1.24\end{array}$ & $\begin{array}{l}0.49 \\
1.76 \\
1.48 \\
1.39 \\
1.23\end{array}$ & $\begin{array}{l}0.33 \\
2.03 \\
1.65 \\
1.55 \\
1.34\end{array}$ & $\begin{array}{l}0.34 \\
1.94 \\
1.58 \\
1.48 \\
1.29\end{array}$ & $\begin{array}{l}0.32 \\
2.11 \\
1.69 \\
1.58 \\
1.35\end{array}$ & $\begin{array}{l}0.36 \\
1.71 \\
1.40 \\
1.32 \\
1.15\end{array}$ & $\begin{array}{l}0.33 \\
1.86 \\
1.50 \\
1.40 \\
1.21\end{array}$ & $\begin{array}{l}0.34 \\
2.07 \\
1.70 \\
1.60 \\
1.39\end{array}$ & $\begin{array}{l}0.33 \\
1.92 \\
1.56 \\
1.47 \\
1.27\end{array}$ & $\begin{array}{l}0.33 \\
1.78 \\
1.46 \\
1.37 \\
1.19\end{array}$ & $\begin{array}{l}0.34 \\
1.991 \\
1.55 \\
1.46 \\
1.26\end{array}$ & $\begin{array}{l}0.42 \\
1.32 \\
1.12 \\
1.05 \\
0.93\end{array}$ & $\begin{array}{l}0.44 \\
1.43 \\
1.21 \\
1.15 \\
1.01\end{array}$ \\
\hline & $\begin{array}{l}\mathrm{Rb} \\
\mathrm{K} \\
\mathrm{Sr} \\
\mathrm{Y} \\
2 \mathrm{r} \\
\mathrm{Nb} \\
\mathrm{Ni}\end{array}$ & $\begin{array}{r}31.9 \\
13210 \\
547 \\
19.1 \\
127 \\
6.2 \\
12\end{array}$ & $\begin{array}{r}32.0 \\
13533 \\
546 \\
19.9 \\
127 \\
6.4 \\
i 2\end{array}$ & $\begin{array}{r}34.6 \\
13984 \\
513 \\
19.8 \\
131 \\
6.1 \\
8\end{array}$ & $\begin{array}{r}29.0 \\
11186 \\
533 \\
18.4 \\
110 \\
5.6 \\
8\end{array}$ & $\begin{array}{r}38.9 \\
15810 \\
556 \\
17.4 \\
145 \\
6.7 \\
8\end{array}$ & $\begin{array}{r}36.8 \\
15695 \\
559 \\
19.9 \\
141 \\
6.4 \\
8\end{array}$ & $\begin{array}{r}39.9 \\
17292 \\
523 \\
18.7 \\
144 \\
6.2 \\
6\end{array}$ & $\begin{array}{r}30.4 \\
13148 \\
614 \\
16.3 \\
129 \\
5.6 \\
17\end{array}$ & $\begin{array}{r}47.8 \\
18309 \\
506 \\
16.8 \\
148 \\
6.4 \\
10\end{array}$ & $\begin{array}{r}40.5 \\
15073 \\
507 \\
17.4 \\
135 \\
7.2 \\
7\end{array}$ & $\begin{array}{r}38.8 \\
15281 \\
535 \\
17.0 \\
140 \\
6.7 \\
i 1\end{array}$ & $\begin{array}{r}36.2 \\
15204 \\
610 \\
17.8 \\
133 \\
6.1 \\
9\end{array}$ & $\begin{array}{r}36.8 \\
14600 \\
522 \\
15.5 \\
131 \\
5.8 \\
10\end{array}$ & $\begin{array}{r}19.0 \\
8575 \\
682 \\
12.1 \\
92 \\
5.5 \\
43\end{array}$ & $\begin{array}{r}22.2 \\
9495 \\
592 \\
16.3 \\
95 \\
5.3 \\
16\end{array}$ \\
\hline & $\begin{array}{c}\mathrm{K} / \mathrm{Rb} \\
\mathrm{K} / \mathrm{Y} \\
2 \mathrm{r} / \mathrm{Y} \\
\mathrm{Rb} / 2 \mathrm{r} \\
\mathrm{K} / 2 \mathrm{r}\end{array}$ & $\begin{array}{r}414.1 \\
690.2 \\
6.6 \\
0.252 \\
104.2\end{array}$ & $\begin{array}{l}423.2 \\
679.7 \\
6.4 \\
0.253 \\
106.9\end{array}$ & $\begin{array}{l}404.5 \\
706.2 \\
0.6 \\
0.265 \\
107.0\end{array}$ & $\begin{array}{l}386.3 \\
607.6 \\
6.0 \\
0.262 \\
101.3\end{array}$ & $\begin{array}{r}406.3 \\
906.8 \\
8.3 \\
0.268 \\
109.0\end{array}$ & $\begin{array}{l}426.3 \\
787.9 \\
7.1 \\
0.261 \\
111.4\end{array}$ & $\begin{array}{l}433.6 \\
923.2 \\
7.7 \\
0.278 \\
120.4\end{array}$ & $\begin{array}{l}432.4 \\
809.1 \\
7.9 \\
0.236 \\
101.9\end{array}$ & $\begin{array}{r}382.9 \\
1087.2 \\
8.8 \\
0.822 \\
123.4\end{array}$ & $\begin{array}{l}372.0 \\
864.3 \\
7.7 \\
0.301 \\
111.8\end{array}$ & $\begin{array}{r}393.5 \\
896.8 \\
8.2 \\
0.277 \\
109.2\end{array}$ & $\begin{array}{r}419.5 \\
855.6 \\
7.5 \\
0.273 \\
114.7\end{array}$ & $\begin{array}{r}397.1 \\
942.5 \\
8.5 \\
0.280 \\
111.4\end{array}$ & $\begin{array}{r}451.8 \\
706.4 \\
7.6 \\
0.205 \\
92.7\end{array}$ & $\begin{array}{r}427.7 \\
581.8 \\
5.8 \\
0.233 \\
99.7\end{array}$ \\
\hline & $\begin{array}{c}\text { of } \\
\text { pl } \\
\text { cpx } \\
\text { opx }\end{array}$ & $\begin{array}{r}0.3 \\
34.3 \\
6.0 \\
5.5\end{array}$ & $\begin{array}{r}31.8 \\
4.0 \\
5.8\end{array}$ & $\begin{array}{r}37.5 \\
6.8 \\
5.0\end{array}$ & $\begin{array}{r}18.8 \\
2.5 \\
2.3\end{array}$ & $\begin{array}{r}24.8 \\
2.5 \\
2.3\end{array}$ & $\begin{array}{r}21.8 \\
2.3 \\
2.3\end{array}$ & $\begin{array}{r}32.5 \\
4.5 \\
2.0\end{array}$ & $\begin{array}{r}0.3 \\
22.5 \\
3.3 \\
2.5\end{array}$ & 22.8 & $\begin{array}{r}25.3 \\
4.3 \\
3.0 \\
0.3\end{array}$ & $\begin{array}{r}28.0 \\
2.3 \\
1.8\end{array}$ & $\begin{array}{r}20.0 \\
3.3 \\
1.8\end{array}$ & $\begin{array}{r}20.0 \\
2.3 \\
1.5\end{array}$ & $\begin{array}{r}31.0 \\
3.8 \\
5.5\end{array}$ & $\begin{array}{r}26.3 \\
5.3 \\
1.8\end{array}$ \\
\hline & $\begin{array}{r}n b \\
m t \\
\text { gms } \\
\text { notes }\end{array}$ & $\begin{array}{r}1.3 \\
52.8 \\
\text { osy }\end{array}$ & $\begin{array}{r}1.0 \\
57.5\end{array}$ & $\begin{array}{r}1.8 \\
49.0\end{array}$ & $\begin{array}{r}0.3 \\
76.3\end{array}$ & $\begin{array}{r}0.5 \\
70.5 \\
\text { mivg }\end{array}$ & $\begin{array}{l}0.8 \\
73.0 \\
\text { orxn }\end{array}$ & $\begin{array}{r}0.5 \\
60.5 \\
\text { rivg }\end{array}$ & $\begin{array}{r}0.3 \\
71.3\end{array}$ & $\begin{array}{r}0.8 \\
62.3 \\
\text { hop }\end{array}$ & & $\begin{array}{r}0.8 \\
67.3 \\
c r .0\end{array}$ & $\begin{array}{r}1.3 \\
73.8\end{array}$ & & $\begin{array}{r}59.8 \\
\text { p,spph }\end{array}$ & $\begin{array}{r}0.8 \\
66.0\end{array}$ \\
\hline
\end{tabular}

WHOLE ROCK 2 


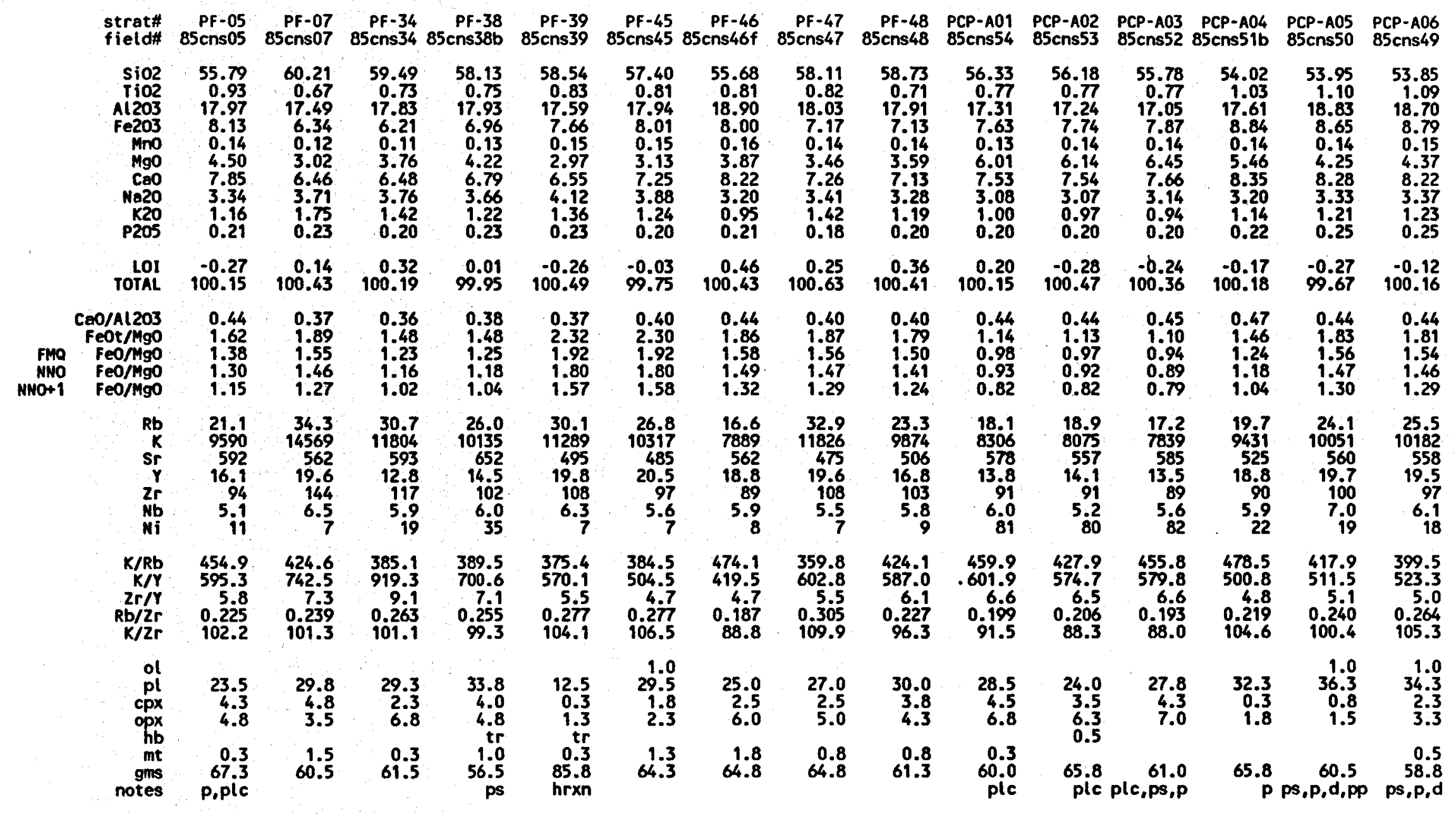

WHOLE ROCK 3 


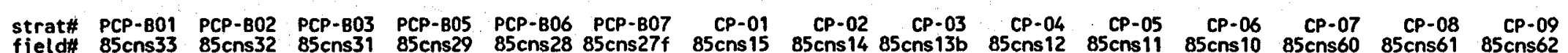

\begin{tabular}{|c|c|c|c|c|c|c|c|c|c|c|c|c|c|c|c|}
\hline $\begin{array}{r}\text { sio2 } \\
\text { Ti02 } \\
\text { Alzo3 } \\
\text { Fez03 } \\
\text { Mino } \\
\text { MgO } \\
\text { CoO } \\
\text { Nazo } \\
\text { K20 } \\
\text { P205 }\end{array}$ & $\begin{array}{r}57.19 \\
0.82 \\
17.21 \\
7.58 \\
0.13 \\
4.89 \\
7.43 \\
3.27 \\
1.26 \\
0.22\end{array}$ & $\begin{array}{r}53.73 \\
1.12 \\
19.07 \\
8.73 \\
0.14 \\
4.07 \\
8.29 \\
3.36 \\
1.24 \\
0.26\end{array}$ & $\begin{array}{r}53.61 \\
1.10 \\
18.40 \\
9.03 \\
0.15 \\
4.62 \\
8.30 \\
3.33 \\
1.20 \\
0.25\end{array}$ & $\begin{array}{r}53.63 \\
1.12 \\
18.31 \\
9.08 \\
0.15 \\
4.79 \\
8.34 \\
3.16 \\
1.18 \\
0.24\end{array}$ & $\begin{array}{r}53.52 \\
1.12 \\
18.25 \\
9.19 \\
0.15 \\
4.78 \\
8.38 \\
3.17 \\
1.20 \\
0.24\end{array}$ & $\begin{array}{r}53.58 \\
1.10 \\
18.60 \\
8.89 \\
0.15 \\
4.63 \\
8.35 \\
3.26 \\
1.20 \\
0.25\end{array}$ & $\begin{array}{r}56.43 \\
0.84 \\
18.18 \\
7.94 \\
0.14 \\
4.57 \\
7.19 \\
3.30 \\
1.19 \\
0.23\end{array}$ & $\begin{array}{r}56.64 \\
0.83 \\
18.00 \\
7.63 \\
0.14 \\
4.54 \\
7.33 \\
3.35 \\
1.27 \\
0.27\end{array}$ & $\begin{array}{r}56.91 \\
0.83 \\
17.95 \\
7.46 \\
0.13 \\
4.69 \\
7.07 \\
3.53 \\
1.18 \\
0.27\end{array}$ & $\begin{array}{r}54.20 \\
0.83 \\
17.40 \\
8.24 \\
0.15 \\
6.63 \\
8.25 \\
3.21 \\
0.86 \\
0.22\end{array}$ & $\begin{array}{r}54.11 \\
0.83 \\
17.53 \\
8.19 \\
0.14 \\
6.55 \\
8.37 \\
3.22 \\
0.84 \\
0.22\end{array}$ & $\begin{array}{r}53.81 \\
0.81 \\
17.67 \\
8.12 \\
0.14 \\
6.61 \\
8.61 \\
3.27 \\
0.73 \\
0.23\end{array}$ & $\begin{array}{r}53.89 \\
0.81 \\
17.69 \\
8.08 \\
0.15 \\
6.52 \\
8.62 \\
3.27 \\
0.74 \\
0.23\end{array}$ & $\begin{array}{r}54.15 \\
0.83 \\
18.19 \\
7.96 \\
0.15 \\
5.48 \\
8.44 \\
3.74 \\
0.79 \\
0.26\end{array}$ & $\begin{array}{r}55.17 \\
0.73 \\
18.27 \\
7.62 \\
0.14 \\
4.81 \\
8.21 \\
3.87 \\
0.95 \\
0.24\end{array}$ \\
\hline $\begin{array}{r}\text { LOI } \\
\text { TOTAL }\end{array}$ & $\begin{array}{r}-0.24 \\
100.58\end{array}$ & $\begin{array}{r}-0.45 \\
100.61\end{array}$ & $\begin{array}{r}-0.39 \\
100.11\end{array}$ & $\begin{array}{l}-0.04 \\
99.49\end{array}$ & $\begin{array}{r}-0.06 \\
100.27\end{array}$ & $\begin{array}{r}-0.23 \\
100.01\end{array}$ & $\begin{array}{r}-0.34 \\
100.10\end{array}$ & $\begin{array}{r}-0.16 \\
100.35\end{array}$ & $\begin{array}{r}-0.06 \\
100.35\end{array}$ & $\begin{array}{r}-0.20 \\
100.52\end{array}$ & $\begin{array}{r}-0.40 \\
100.09\end{array}$ & $\begin{array}{r}-0.40 \\
100.56\end{array}$ & $\begin{array}{r}-0.43 \\
100.23\end{array}$ & $\begin{array}{r}-0.27 \\
100.70\end{array}$ & $\begin{array}{r}0.10 \\
100.45\end{array}$ \\
\hline $\begin{array}{l}\text { o/Alzos } \\
\text { eOt/Mgo } \\
\text { Feo/Mgo } \\
\text { Feo/Mgo } \\
\text { Feo/Mgo }\end{array}$ & $\begin{array}{l}0.43 \\
1.39 \\
1.18 \\
1.11 \\
0.98\end{array}$ & $\begin{array}{l}0.43 \\
1.93 \\
1.64 \\
1.55 \\
1.38\end{array}$ & $\begin{array}{l}0.45 \\
1.76 \\
1.50 \\
1.42 \\
1.26\end{array}$ & $\begin{array}{l}0.46 \\
1.71 \\
1.46 \\
1.38 \\
1.22\end{array}$ & $\begin{array}{l}0.46 \\
1.73 \\
1.48 \\
1.40 \\
1.24\end{array}$ & $\begin{array}{l}0.45 \\
1.73 \\
1.48 \\
1.39 \\
1.24\end{array}$ & $\begin{array}{l}0.40 \\
1.56 \\
1.33 \\
1.26 \\
1.11\end{array}$ & $\begin{array}{l}0.41 \\
1.51 \\
1.28 \\
1.21 \\
1.07\end{array}$ & $\begin{array}{l}0.39 \\
1.43 \\
1.21 \\
1.14 \\
1.01\end{array}$ & $\begin{array}{l}0.47 \\
1.12 \\
0.96 \\
0.91 \\
0.81\end{array}$ & $\begin{array}{l}0.48 \\
1.13 \\
0.97 \\
0.92 \\
0.82\end{array}$ & $\begin{array}{l}0.49 \\
1.11 \\
0.95 \\
0.90 \\
0.81\end{array}$ & $\begin{array}{l}0.49 \\
1.12 \\
0.96 \\
0.91 \\
0.81\end{array}$ & $\begin{array}{l}0.46 \\
1.31 \\
1.12 \\
1.05 \\
0.94\end{array}$ & $\begin{array}{l}0.45 \\
1.43 \\
1.21 \\
1.14 \\
1.01\end{array}$ \\
\hline $\begin{array}{c}R b \\
K \\
S r \\
Y \\
Z r \\
M b \\
N i\end{array}$ & $\begin{array}{r}25.8 \\
10457 \\
583 \\
17.4 \\
103 \\
5.7 \\
20\end{array}$ & $\begin{array}{r}21.4 \\
10268 \\
570 \\
20.0 \\
99 \\
6.5 \\
14\end{array}$ & $\begin{array}{r}21.3 \\
9995 \\
554 \\
21.6 \\
94 \\
6.6 \\
15\end{array}$ & $\begin{array}{r}23.0 \\
9759 \\
544 \\
20.3 \\
95 \\
6.4 \\
14\end{array}$ & $\begin{array}{r}23.6 \\
9929 \\
547 \\
19.4 \\
95 \\
6.6 \\
15\end{array}$ & $\begin{array}{r}22.5 \\
9938 \\
549 \\
19.6 \\
97 \\
5.8 \\
14\end{array}$ & $\begin{array}{r}24.8 \\
9918 \\
571 \\
17.3 \\
99 \\
5.6 \\
27\end{array}$ & $\begin{array}{r}27.6 \\
10572 \\
631 \\
16.5 \\
102 \\
6.4 \\
25\end{array}$ & $\begin{array}{r}25.3 \\
9756 \\
666 \\
14.7 \\
102 \\
6.6 \\
43\end{array}$ & $\begin{array}{r}15.8 \\
7171 \\
558 \\
15.2 \\
83 \\
5.8 \\
71\end{array}$ & $\begin{array}{r}14.2 \\
6939 \\
584 \\
15.6 \\
81 \\
6.2 \\
67\end{array}$ & $\begin{array}{r}9.9 \\
6085 \\
618 \\
13.5 \\
77 \\
5.6 \\
67\end{array}$ & $\begin{array}{r}11.3 \\
6103 \\
631 \\
14.2 \\
75 \\
5.7 \\
63\end{array}$ & $\begin{array}{r}8.5 \\
6577 \\
755 \\
14.7 \\
80 \\
5.2 \\
43\end{array}$ & $\begin{array}{r}15.4 \\
7859 \\
666 \\
14.2 \\
85 \\
5.4 \\
27\end{array}$ \\
\hline $\begin{array}{c}K / R b \\
K / Y \\
Z r / Y \\
R b / Z r \\
K / Z r\end{array}$ & $\begin{array}{r}405.2 \\
602.7 \\
5.9 \\
0.251 \\
101.7\end{array}$ & $\begin{array}{r}480.0 \\
514.7 \\
5.0 \\
0.216 \\
103.8\end{array}$ & $\begin{array}{r}470.4 \\
463.4 \\
4.4 \\
0.225 \\
105.8\end{array}$ & $\begin{array}{r}425.0 \\
481.4 \\
4.7 \\
0.243 \\
103.2\end{array}$ & $\begin{array}{r}420.9 \\
510.8 \\
4.9 \\
0.247 \\
104.1\end{array}$ & $\begin{array}{r}442.7 \\
506.8 \\
4.9 \\
0.233 \\
102.9\end{array}$ & $\begin{array}{r}399.4 \\
572.6 \\
5.7 \\
0.252 \\
100.5\end{array}$ & $\begin{array}{r}383.7 \\
641.9 \\
6.2 \\
0.269 \\
103.2\end{array}$ & $\begin{array}{r}385.8 \\
663.2 \\
6.9 \\
0.248 \\
95.7\end{array}$ & $\begin{array}{r}454.7 \\
472.7 \\
5.5 \\
0.190 \\
86.5\end{array}$ & $\begin{array}{r}488.7 \\
444.0 \\
5.2 \\
0.176 \\
86.1\end{array}$ & $\begin{array}{r}612.8 \\
452.4 \\
5.7 \\
0.129 \\
79.3\end{array}$ & $\begin{array}{r}538.7 \\
430.4 \\
5.3 \\
0.152 \\
81.6\end{array}$ & $\begin{array}{r}772.0 \\
448.2 \\
5.5 \\
0.106 \\
82.1\end{array}$ & $\begin{array}{r}512.0 \\
554.6 \\
6.0 \\
0.181 \\
92.7\end{array}$ \\
\hline $\begin{array}{l}o l \\
p l \\
c p x \\
o p x \\
h b\end{array}$ & $\begin{array}{r}14.0 \\
7.0 \\
6.3 \\
t r\end{array}$ & $\begin{array}{r}0.3 \\
33.5 \\
5.3 \\
2.5\end{array}$ & $\begin{array}{r}1.0 \\
31.8 \\
1.3\end{array}$ & $\begin{array}{r}0.5 \\
32.5 \\
0.3 \\
4.8\end{array}$ & $\begin{array}{r}0.5 \\
30.0 \\
1.3 \\
4.5\end{array}$ & $\begin{array}{r}\mathrm{tr} \\
31.5 \\
2.0 \\
2.8\end{array}$ & $\begin{array}{r}0.5 \\
26.0 \\
3.0 \\
3.3\end{array}$ & $\begin{array}{r}29.3 \\
4.0 \\
7.0\end{array}$ & $\begin{array}{r}0.3 \\
19.0 \\
2.5 \\
5.5\end{array}$ & $\begin{array}{r}4.5 \\
17.5 \\
8.0 \\
1.8\end{array}$ & $\begin{array}{r}5.0 \\
22.3 \\
3.5 \\
0.5\end{array}$ & $\begin{array}{r}3.3 \\
16.5 \\
7.3\end{array}$ & $\begin{array}{r}5.5 \\
22.0 \\
3.8 \\
0.5\end{array}$ & $\begin{array}{r}31.3 \\
0.8 \\
1.0\end{array}$ & $\begin{array}{r}1.0 \\
34.3 \\
5.5 \\
1.5\end{array}$ \\
\hline $\begin{array}{r}\text { no } \\
\text { mt } \\
\text { gms } \\
\text { notes }\end{array}$ & $\begin{array}{r}72.8 \\
\text { p }\end{array}$ & 0.8 & 62.3 & $\begin{array}{r}0.3 \\
61.8\end{array}$ & $\begin{array}{r}0.3 \\
63.5 \\
p\end{array}$ & $\begin{array}{r}0.5 \\
63.3\end{array}$ & $\begin{array}{l}67.3 \\
\text { oir }\end{array}$ & 59.8 & $\begin{array}{r}0.3 \\
72.5\end{array}$ & 68.3 & $\begin{array}{r}68.8 \\
\mathrm{cr}\end{array}$ & $\begin{array}{r}73.0 \\
\mathrm{cr}\end{array}$ & $\begin{array}{r}68.3 \\
\mathrm{cr}\end{array}$ & $\begin{array}{r}67.0 \\
p\end{array}$ & $\begin{array}{r}0.5 \\
57.3\end{array}$ \\
\hline
\end{tabular}

WHOLE ROCK 4 


\begin{tabular}{|c|c|c|c|c|c|c|}
\hline $\begin{array}{l}\text { strat\# } \\
\text { fieldd\# }\end{array}$ & $\begin{array}{r}\text { CP-10 } \\
85 \mathrm{ens} 18\end{array}$ & $\begin{array}{r}c P-11 \\
85 c n s 19\end{array}$ & $\begin{array}{r}\mathrm{cP}-12 \\
85 \mathrm{cns} 20\end{array}$ & $\begin{array}{r}\text { CP. } 54 \\
85 \mathrm{cns} 04\end{array}$ & $\begin{array}{r}\text { PUM-16 } \\
85 \mathrm{cns} 16\end{array}$ & $\begin{array}{l}\text { PuM-17 } \\
85 \text { cns } 17\end{array}$ \\
\hline 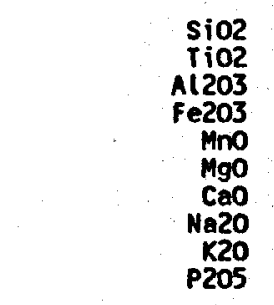 & $\begin{array}{l}55.74 \\
0.76 \\
18.82 \\
7.73 \\
0.14 \\
4.25 \\
7.42 \\
3.82 \\
1.04 \\
0.28\end{array}$ & $\begin{array}{r}55.60 \\
0.77 \\
18.65 \\
8.06 \\
0.06 \\
4.27 \\
7.49 \\
3.70 \\
1.04 \\
0.28\end{array}$ & $\begin{array}{l}55.46 \\
0.76 \\
18.78 \\
7.85 \\
0.14 \\
4.26 \\
7.41 \\
4.01 \\
1.06 \\
0.28\end{array}$ & $\begin{array}{r}59.69 \\
0.69 \\
17.22 \\
6.28 \\
0.11 \\
4.39 \\
6.54 \\
3.66 \\
1.23 \\
0.20\end{array}$ & $\begin{array}{r}54.64 \\
0.83 \\
18.62 \\
8.50 \\
0.15 \\
4.52 \\
7.95 \\
3.57 \\
0.96 \\
0.27\end{array}$ & $\begin{array}{r}54.08 \\
0.86 \\
18.61 \\
8.40 \\
0.14 \\
4.83 \\
8.08 \\
3.71 \\
1.01 \\
0.27\end{array}$ \\
\hline $\begin{array}{l}\text { col } \\
\text { TOAAL }\end{array}$ & $\begin{array}{l}-0.08 \\
99.68\end{array}$ & $\begin{array}{r}-0.17 \\
99.42\end{array}$ & $\begin{array}{r}-0.18 \\
100.29\end{array}$ & $\begin{array}{r}-0.19 \\
100.46\end{array}$ & $\begin{array}{r}-0.03 \\
100.49\end{array}$ & $\begin{array}{r}0.05 \\
99.93\end{array}$ \\
\hline 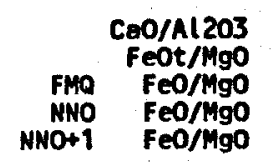 & $\begin{array}{l}0.39 \\
9.64 \\
1.39 \\
1.31 \\
1.16\end{array}$ & $\begin{array}{l}0.40 \\
9.70 \\
i .44 \\
1.36 \\
1.21\end{array}$ & $\begin{array}{l}0.39 \\
9.66 \\
1.40 \\
1.33 \\
1.17\end{array}$ & $\begin{array}{l}0.38 \\
1.29 \\
1.07 \\
1.01 \\
0.89\end{array}$ & $\begin{array}{l}0.43 \\
1: .69 \\
1: 44 \\
1: 36 \\
1.21\end{array}$ & $\begin{array}{l}0.43 \\
1.57 \\
1.33 \\
1.26 \\
1.12\end{array}$ \\
\hline $\begin{array}{l}\text { Rb } \\
K \\
\text { Sr } \\
Y r \\
2 r \\
\text { Sb } \\
\text { Mi }\end{array}$ & $\begin{array}{r}17.4 \\
8654 \\
710 \\
14.9 \\
90 \\
6.1 \\
26\end{array}$ & $\begin{array}{r}18.6 \\
8669 \\
714 . \\
14.7 \\
900 \\
5.8 \\
27\end{array}$ & $\begin{array}{r}18.0 \\
8801 \\
711 \\
14.3 \\
91 \\
6.0 \\
24\end{array}$ & $\begin{array}{r}21.3 \\
10228 \\
676 \\
11.0 \\
107 \\
5.6 \\
45\end{array}$ & $\begin{array}{r}15.0 \\
8011 \\
640 \\
15.8 \\
88 \\
5.8 \\
20\end{array}$ & $\begin{array}{r}15.9 \\
8395 \\
708 \\
14.6 \\
6.3 \\
61\end{array}$ \\
\hline $\begin{array}{c}\text { K/Rb } \\
k r / r \\
2 r / r \\
R b / 2 r \\
k / 2 r\end{array}$ & $\begin{array}{l}497.7 \\
582.4 \\
0.41 \\
0.193 \\
95.9\end{array}$ & $\begin{array}{l}465.3 \\
588.9 \\
6.9 .1 \\
0.207 \\
96.5\end{array}$ & $\begin{array}{l}488.3 \\
616.7 \\
6.3 \\
0.199 \\
97.2\end{array}$ & $\begin{array}{l}479.7 \\
929.8 \\
0.97 \\
0.199 \\
95.5\end{array}$ & $\begin{array}{l}535.1 \\
508.6 \\
5.6 \\
0.170 \\
90.8\end{array}$ & $\begin{array}{l}528.0 \\
575.0 \\
6.22 \\
0.175 \\
92.7\end{array}$ \\
\hline $\begin{array}{l}\text { ol } \\
p l \\
c p x \\
c p x \\
o p x \\
h b\end{array}$ & $\begin{array}{r}0.5 \\
27.0 \\
2.8 \\
2.8 \\
0.5\end{array}$ & $\begin{array}{r}0.5 \\
25.5 \\
3.5 \\
2.0\end{array}$ & $\begin{array}{r}26.3 \\
26.5 \\
1.5 \\
0.0 \\
0.8\end{array}$ & $\begin{array}{r}31.5 \\
3.8 \\
5.0\end{array}$ & $\begin{array}{r}14.0 \\
3.8 \\
3.0 \\
0.5\end{array}$ & \\
\hline $\begin{array}{c}\text { gms } \\
\text { notes }\end{array}$ & 66.5 & $\stackrel{69.0}{p / h}$ & $\begin{array}{l}70.5 \\
\text { hrxn }\end{array}$ & 59.8 & 78.8 & 82.5 \\
\hline
\end{tabular}

explanation of "notes"

explan

cr - chromite inclusions in olivine

d - dunite clats

hop - hornblende al tered to opaque minerals, some cores unat ter

hrxn - reaction rims around hornblende

mvg - microvesicular groundmass, gms may be overestimated

oalt - olivine altered to green fibrous minerals

olr - ol ivine is resorbed

orxn - reaction rims around olivine

osy - symplectic spinel/pyroxene rims on ol ivine

$p$ - pyroxenite clots and cpx and opx megacrysts

plc - anonolously pleochroic cores of orthopyroxenes

pp - plagioctase peridotite clots

ps - aluminous spinel + plos $+/-\operatorname{cpx}$ clots

p/h - pyroxenite clots coated with hornblende

spph - Al-spinel + plagioclase clots, phlogopite bearing 


\section{APPENDIX II - summmary of mineral compositions}

The following table contains coefficients of regression lines of individual elements plotted against $\mathrm{Mg} \#$ or $\mathrm{Ca} /(\mathrm{Ca}+\mathrm{Na})$. Diagrams following the table are plots of the compositions of each mineral species. Notice that the elements described by equations with low correlation coefficients are present in minor amounts or do not vary throughout the compositional ranges of the minerals. 
Coefficients of equations of the form $Y=m * M g \#$ (or An) $+b$ for major rock forming minerals of the Spurr Volcanic Complex. The equation for $\mathrm{K} 20$ in plagioclase is $\mathrm{K} 2 \mathrm{O}=\mathrm{b}+(\mathrm{m} * \mathrm{An})+\mathrm{m} 2 * \mathrm{An} \wedge 2)$. Graphs of mineral compositions follow.

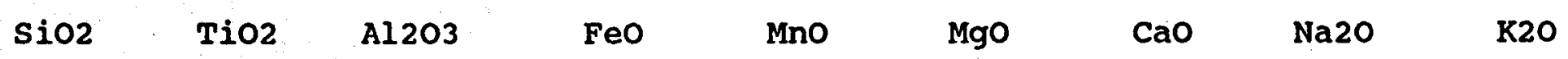

\title{
PIAGIOCLASE
}

$\mathrm{m} 2$

$\mathrm{m}$
$\mathbf{b}$

-0.25997
68.80400

0.99422

0.00035
0.06410
0.13776

0.17376

0.00165

19.03200

0.43076

OLIVINE

$\begin{array}{rrr}\text { m } & 0.09685 & -0.00134 \\ \mathrm{~b} & 30.01827 & 0.12663 \\ \mathrm{r} & 0.80823 & 0.27496\end{array}$

0.00000

0.17346
$0.20194-0$

0.08251

0.99890

$-0.10595$

10.69600

0.99871

0.00026

$-0.04316$

1.86430

0.93179

\section{CLINOPYROXENE \\ m $\quad-0.05224 \quad 0.01464 \quad 0.18039-0.34990-0.01652$ \\ b $\quad 55.95000-0.61286-0.1162935 .99200 \quad 1.56660$ \\ $\begin{array}{llllll}\text { r } & 0.21202 & 0.25975 & 0.59154 & 0.94537 & 0.72212\end{array}$ \\ 1.15500 \\ 0.80599 \\ $0.02516-0.00552$ \\ $18.70100 \quad 0.75962$ \\ 0.131920 .37875}

ORTHOPYROXENE
$\mathrm{m} \quad 0.00863$
$47.24600-0.00221$
$\mathbf{b}$
0.55910
0.39502
$-0.97339$
58.84200
2.10000
$\begin{array}{rrr}-0.34237 & -0.55267 & 0.17821 \\ 0.97884 & 0.43942 & 0.13905\end{array}$
$-0.02787-0.00206$

$-0.00313$

$-0.56820-0.02245$

0.39640

\section{HORNBLENDE}

$\begin{array}{rrr}\mathrm{m} & 0.01919 & -0.07650 \\ \mathrm{~b} & 40.37270 & 9.40623 \\ \mathrm{r} & 0.12422 & 0.83337\end{array}$

$0.08042-0.16380-0.00340$ $\begin{array}{llll}5.76434 & 25.64760 & 0.44704\end{array}$ $\begin{array}{lll}0.77753 & 0.91109 & 0.52844\end{array}$

$0.11598 \quad 0.00481$ $4.27083 \quad 10.87210$

$0.94103 \quad 0.18700$

$0.00077-0.00460$

$2.44757 \quad 0.73472$

$r$

0.124220 .83337

\begin{abstract}
0.911090 .5284
\end{abstract}




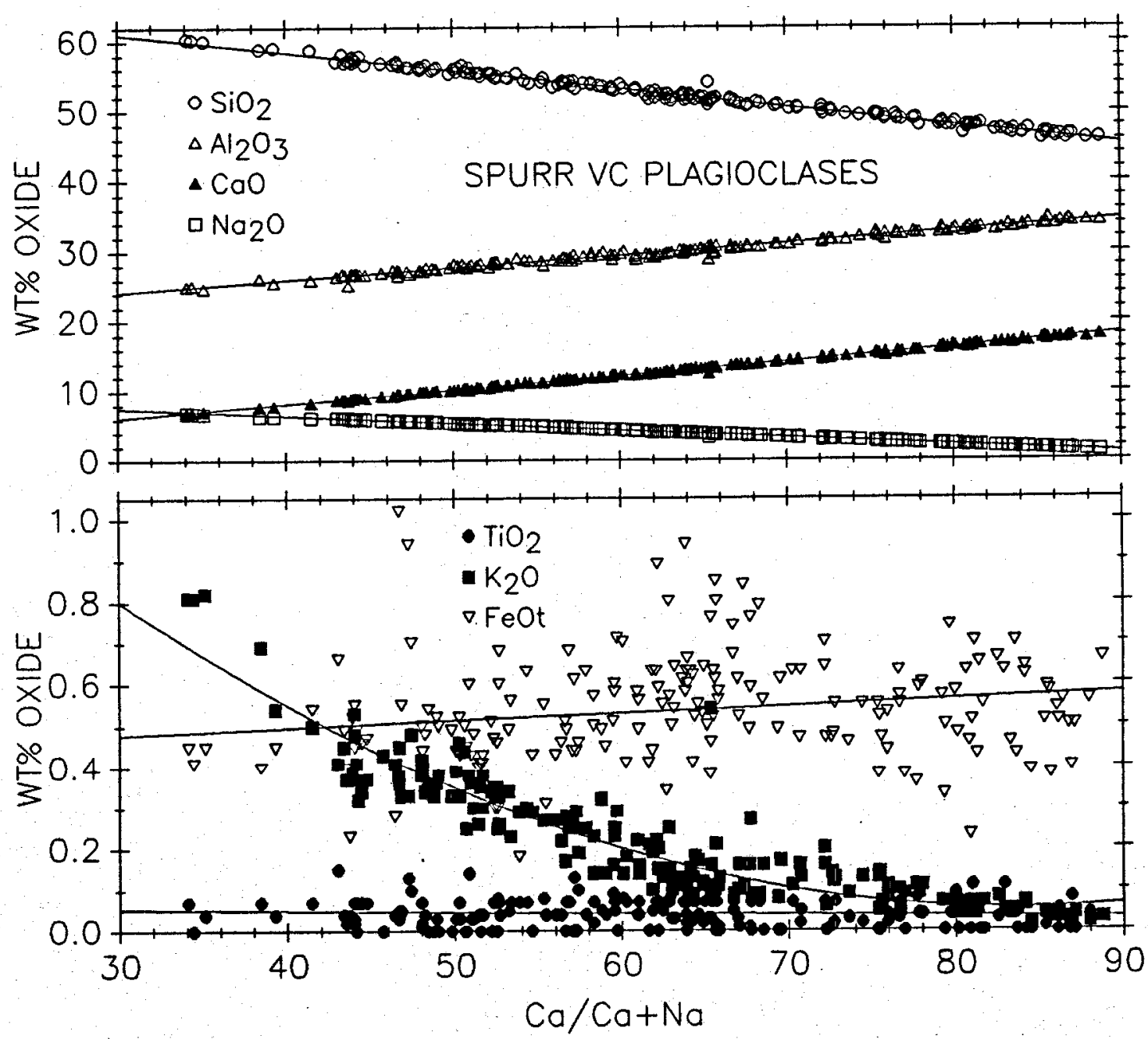




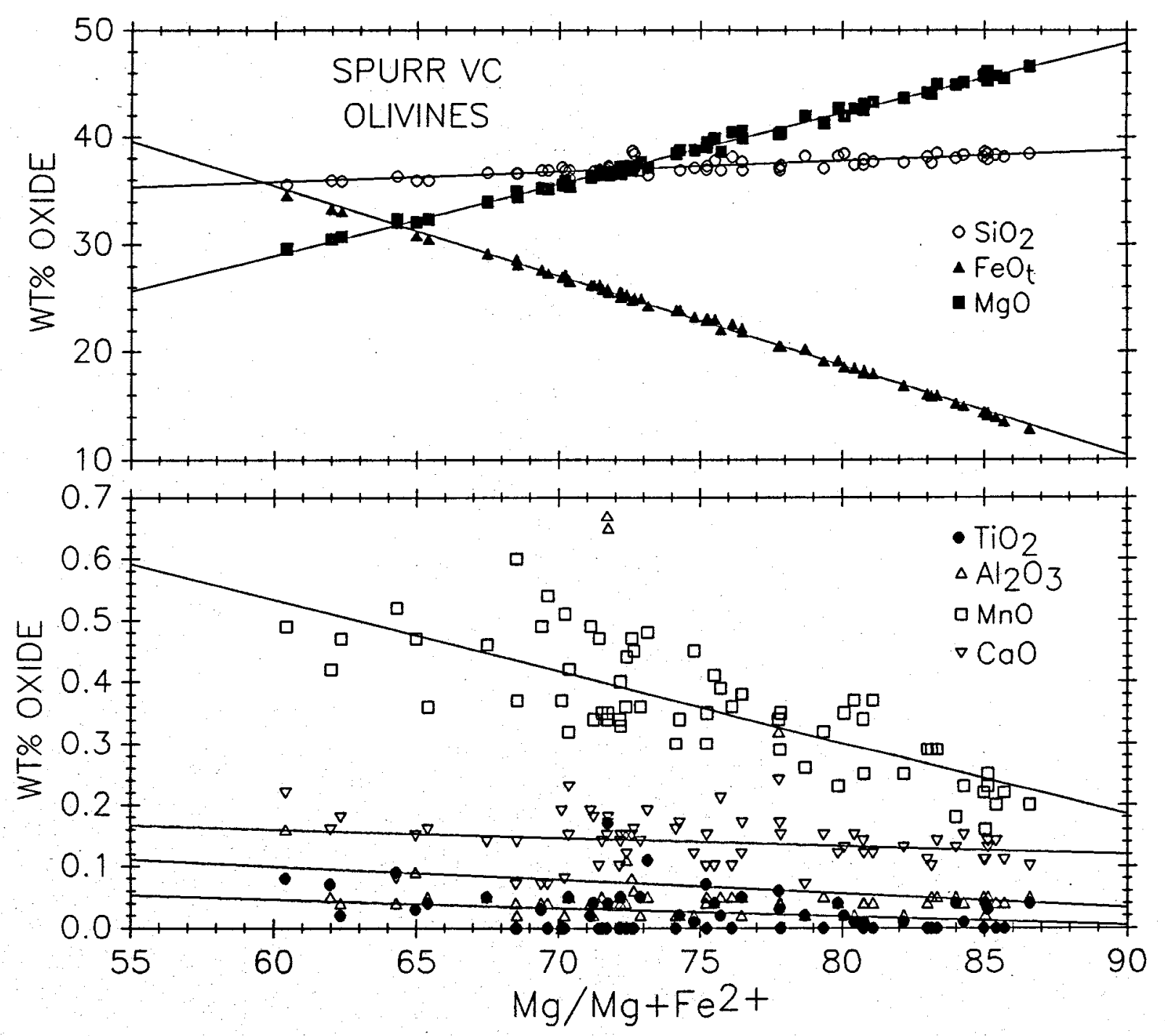




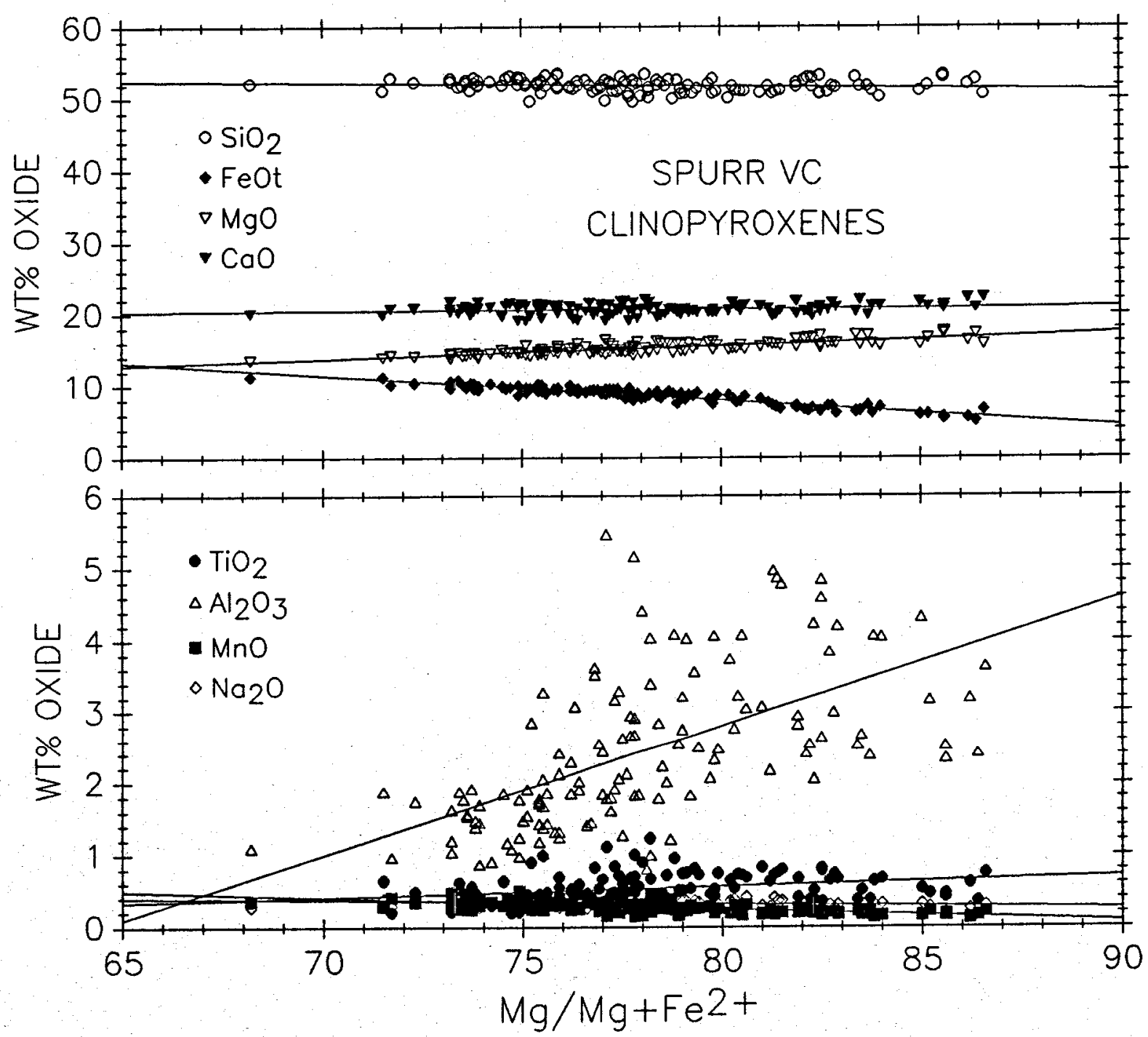



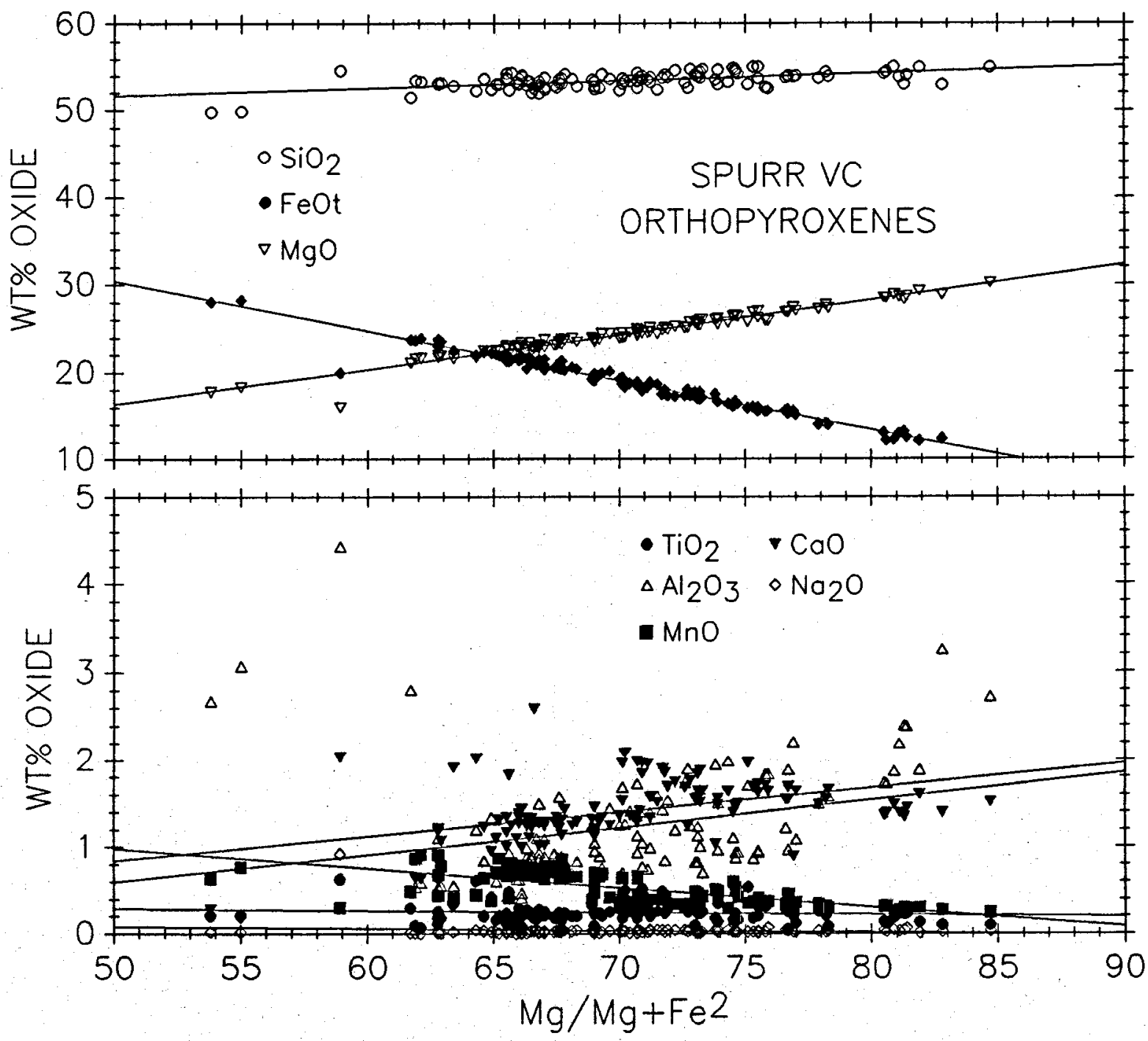


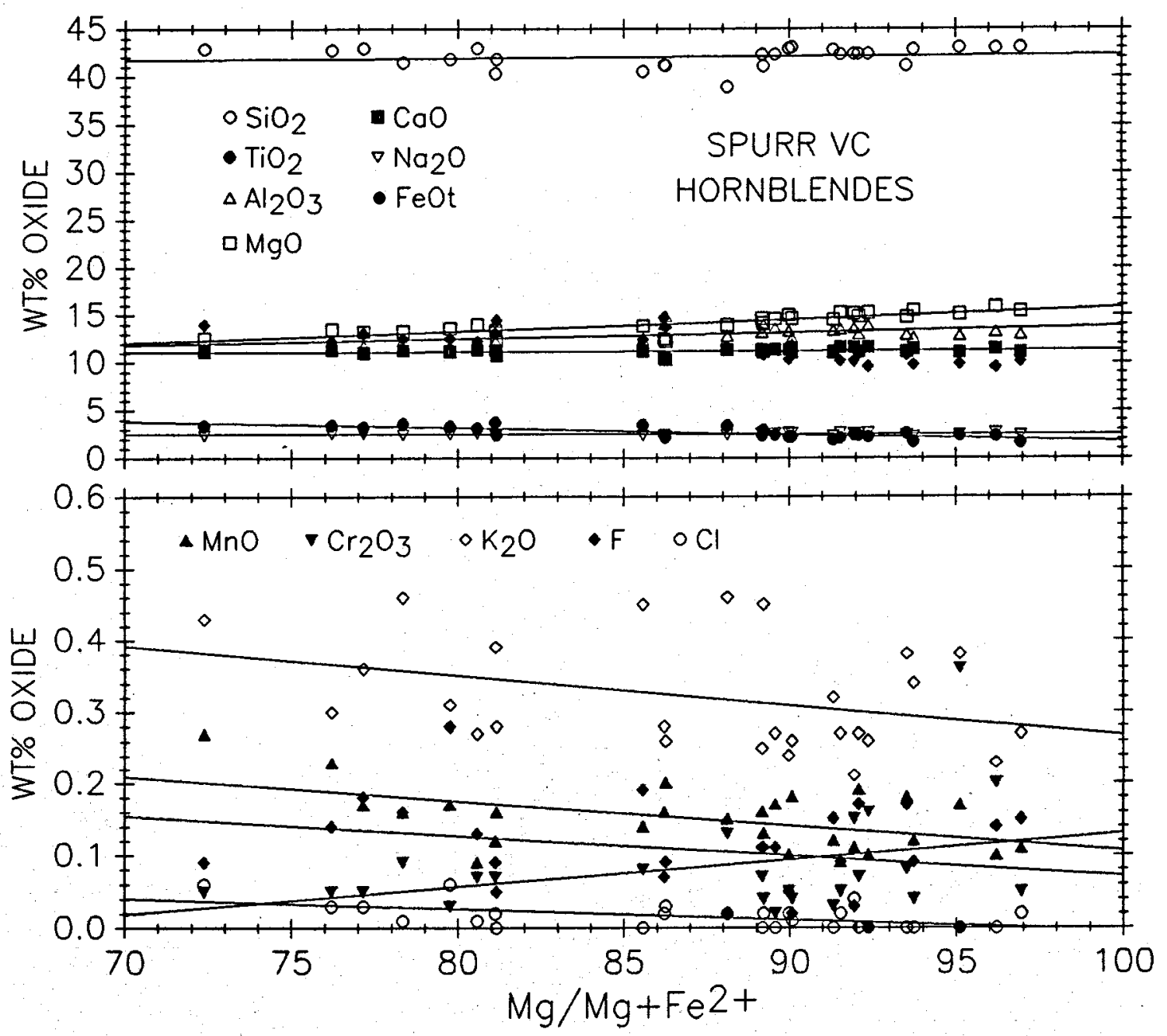




\section{APPENDIX III - Plagioclase compositions}

Plagioclase compositons were determined on the JEOL JXA-733 microprobe at southern Methodist University using standard analytical stratagies and instrumental settings. 
Spurr Volcanic Complex plagioclase analyses

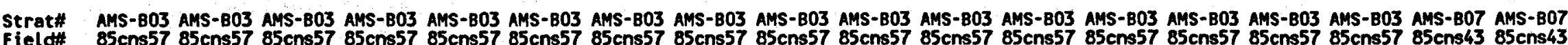

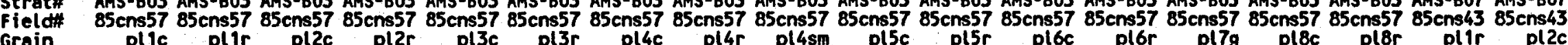

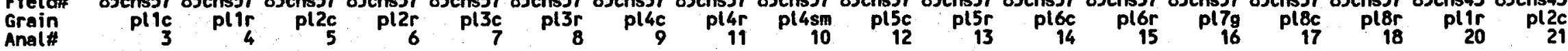
wt\% oxides

\begin{tabular}{|c|c|c|c|c|c|c|c|c|c|c|c|c|c|c|c|c|c|c|}
\hline $\begin{array}{l}02 \\
02 \\
203 \\
203 \\
0 \\
0 \\
20 \\
0\end{array}$ & $\begin{array}{r}54.02 \\
0.00 \\
28.67 \\
0.27 \\
0.18 \\
11.18 \\
4.94 \\
0.29 \\
99.56\end{array}$ & $\begin{array}{r}53.13 \\
0.07 \\
29.37 \\
0.63 \\
0.02 \\
12.31 \\
4.45 \\
0.25 \\
100.22 \\
0.58\end{array}$ & $\begin{array}{r}0.00 \\
29.70 \\
0.33 \\
0.11 \\
12.57 \\
4.19 \\
0.21 \\
99.43\end{array}$ & $\begin{array}{r}56.84 \\
0.00 \\
27.01 \\
0.23 \\
0.23 \\
9.31 \\
5.83 \\
0.43 \\
99.87\end{array}$ & $\begin{array}{r}53.45 \\
0.04 \\
28.76 \\
0.39 \\
0.08 \\
11.48 \\
4.80 \\
0.27 \\
99.27\end{array}$ & $\begin{array}{r}56.22 \\
0.07 \\
27.31 \\
0.42 \\
0.01 \\
9.87 \\
5.66 \\
0.38 \\
09.04\end{array}$ & $\begin{array}{r}51.13 \\
0.00 \\
30.72 \\
0.55 \\
0.06 \\
14.01 \\
3.46 \\
0.16 \\
100.10\end{array}$ & $\begin{array}{r}49.56 \\
0.03 \\
31.68 \\
0.42 \\
0.08 \\
14.94 \\
2.90 \\
0.09 \\
09.70\end{array}$ & $\begin{array}{r}50.57 \\
0.02 \\
31.50 \\
0.34 \\
0.16 \\
14.42 \\
3.20 \\
0.16 \\
100.37\end{array}$ & $\begin{array}{r}47.92 \\
0.04 \\
32.55 \\
0.42 \\
0.22 \\
15.75 \\
2.38 \\
0.11 \\
\infty\end{array}$ & $\begin{array}{r}51.66 \\
0.04 \\
30.25 \\
0.56 \\
0.04 \\
13.30 \\
3.92 \\
0.97\end{array}$ & $\begin{array}{r}0 . \\
30 \\
0 \\
0 \\
13 \\
3 \\
0 .\end{array}$ & $\begin{array}{r}0 . \\
30 . \\
0 . \\
0 . \\
13 . \\
3 . \\
0 .\end{array}$ & $\begin{array}{r}52.95 \\
0.00 \\
29.55 \\
0.58 \\
0.19 \\
12.35 \\
4.41 \\
0.29\end{array}$ & $\begin{array}{r}56 \\
0 \\
27 \\
0 \\
0 \\
10 \\
5 \\
0 \\
100 \\
0\end{array}$ & $\begin{array}{l}9 \\
2 \\
5 \\
1 \\
7 \\
3\end{array}$ & $\begin{array}{r}0 \\
33 \\
0 \\
0 \\
17 \\
1 \\
0\end{array}$ & 0 \\
\hline
\end{tabular}
atons $/ 80$

$\begin{array}{lll}\text { atons } / 8 & 0 \\ \mathbf{S i} & 2 \\ \mathbf{T i} & 0 \\ \mathbf{A l} & 1 \\ \mathbf{F e 3 +} & 0 \\ \mathrm{Fe2+} & 0 \\ \mathbf{C a} & 0 \\ \mathbf{M a} & 0 \\ \mathbf{K} & 0 \\ \text { tot } & 5\end{array}$

$\begin{array}{lllllllllllllllllllllllllll}2.4547 & 2.4088 & 2.3895 & 2.5588 & 2.4392 & 2.5343 & 2.3304 & 2.2727 & 2.2996 & 2.2132 & 2.3550 & 2.3367 & 2.3667 & 2.4008 & 2.5280 & 2.5345 & 2.1593 & 2.1351\end{array}$

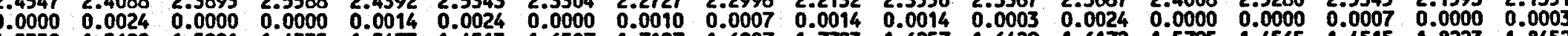
$\begin{array}{llllllllllllllllllllllll}1.5359 & 1.5698 & 1.5991 & 1.4335 & 1.5473 & 1.4513 & 1.6507 & 1.7127 & 1.6887 & 1.7723 & 1.6257 & 1.6429 & 1.6172 & 1.5795 & 1.4565 & 1.4515 & 1.8223 & 1.8452\end{array}$ $\begin{array}{llllllllllllllllll}0.0094 & 0.0213 & 0.0114 & 0.0077 & 0.0135 & 0.0144 & 0.0189 & 0.0145 & 0.0116 & 0.0145 & 0.0193 & 0.0198 & 0.0161 & 0.0197 & 0.0154 & 0.0141 & 0.0184 & 0.0197\end{array}$ $\begin{array}{lllllllllllllllllllll}0.0069 & 0.0006 & 0.0042 & 0.0085 & 0.0029 & 0.0003 & 0.0025 & 0.0031 & 0.0063 & 0.0087 & 0.0016 & 0.0000 & 0.0037 & 0.0072 & 0.0034 & 0.0026 & 0.0055 & 0.0001\end{array}$

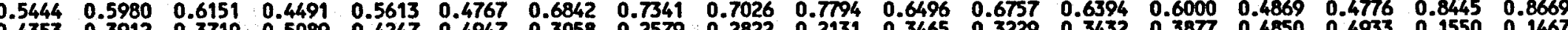
$\begin{array}{llllllllllllllllll}0.4353 & 0.3912 & 0.3710 & 0.5089 & 0.4247 & 0.4947 & 0.3058 & 0.2579 & 0.2822 & 0.2131 & 0.3465 & 0.3229 & 0.3432 & 0.3877 & 0.4850 & 0.4933 & 0.1550 & 0.1467\end{array}$ $\begin{array}{lllllllllllllllllll}0.0168 & 0.0145 & 0.0122 & 0.0247 & 0.0157 & 0.0219 & 0.0093 & 0.0053 & 0.0093 & 0.0065 & 0.0099 & 0.0093 & 0.0105 & 0.0168 & 0.0218 & 0.0231 & 0.0041 & 0.0024 \\ 5.0034 & 5.0067 & 5.0026 & 4.9912 & 5.0060 & 4.9960 & 5.0018 & 5.0014 & 5.0010 & 5.0091 & 5.0090 & 5.0077 & 4.9992 & 5.0117 & 4.9971 & 4.9973 & 5.0091 & 5.0164\end{array}$

$\begin{array}{lllllllllllllllllllllllll}\text { An } & & 0.5463 & 0.5958 & 0.6161 & 0.4570 & 0.5603 & 0.4799 & 0.6847 & 0.7361 & 0.7068 & 0.7802 & 0.6458 & 0.6704 & 0.6438 & 0.5973 & 0.4900 & 0.4805 & 0.8415 & 0.8533\end{array}$ $\begin{array}{lllllllllllllllllll}\text { Ab } & 0.4368 & 0.3898 & 0.3716 & 0.5179 & 0.4240 & 0.4981 & 0.3060 & 0.2586 & 0.2838 & 0.2133 & 0.3444 & 0.3204 & 0.3456 & 0.3860 & 0.4881 & 0.4962 & 0.1544 & 0.1444 \\ \text { or } & 0.0169 & 0.0144 & 0.0123 & 0.0251 & 0.0157 & 0.0220 & 0.0093 & 0.0053 & 0.0093 & 0.0065 & 0.0098 & 0.0092 & 0.0105 & 0.0167 & 0.0219 & 0.0233 & 0.0041 & 0.0023\end{array}$ 


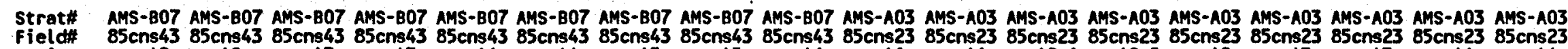

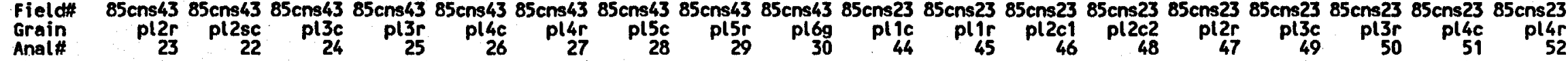

\begin{tabular}{|c|c|c|c|c|c|c|c|c|c|c|c|c|c|c|c|c|c|c|}
\hline $\begin{array}{l}\text { wt\% oxide } \\
\text { SiO2 } \\
\text { TiO2 } \\
\text { AlzO3 } \\
\text { FezO3 } \\
\text { FeO } \\
\text { CaO } \\
\text { Na2O } \\
\text { K2O } \\
\text { tot } \\
\text { feO meas. }\end{array}$ & $\begin{array}{r}47.17 \\
0.03 \\
33.06 \\
0.67 \\
0.05 \\
16.80 \\
1.91 \\
0.08 \\
99.78 \\
0.66\end{array}$ & $\begin{array}{r}50.83 \\
0.00 \\
30.74 \\
0.60 \\
0.22 \\
13.86 \\
3.47 \\
0.27 \\
99.99 \\
0.76\end{array}$ & $\begin{array}{r}46.52 \\
0.00 \\
34.13 \\
0.55 \\
0.01 \\
17.84 \\
1.43 \\
0.04 \\
100.52 \\
0.50\end{array}$ & $\begin{array}{r}47.96 \\
0.00 \\
33.36 \\
0.55 \\
0.16 \\
16.71 \\
2.06 \\
0.07 \\
100.86 \\
0.65\end{array}$ & $\begin{array}{r}46.21 \\
0.05 \\
33.90 \\
0.41 \\
0.14 \\
17.36 \\
1.52 \\
0.03 \\
99.62 \\
0.51\end{array}$ & $\begin{array}{r}46.80 \\
0.00 \\
33.74 \\
0.55 \\
0.14 \\
17.22 \\
1.75 \\
0.06 \\
100.27 \\
0.64\end{array}$ & $\begin{array}{r}46.73 \\
0.04 \\
33.28 \\
0.53 \\
0.22 \\
16.80 \\
1.79 \\
0.05 \\
99.44 \\
0.70\end{array}$ & $\begin{array}{r}47.99 \\
0.07 \\
32.64 \\
0.58 \\
0.05 \\
16.11 \\
2.29 \\
0.07 \\
99.80 \\
0.57\end{array}$ & $\begin{array}{r}51.73 \\
0.07 \\
29.82 \\
0.73 \\
0.15 \\
12.89 \\
4.05 \\
0.25 \\
99.68 \\
0.80\end{array}$ & $\begin{array}{r}50.73 \\
0.01 \\
30.94 \\
0.31 \\
0.21 \\
13.77 \\
3.53 \\
0.16 \\
99.66 \\
0.49\end{array}$ & $\begin{array}{r}54.82 \\
0.05 \\
28.28 \\
0.37 \\
0.15 \\
10.86 \\
5.05 \\
0.34 \\
99.93 \\
0.49\end{array}$ & $\begin{array}{r}55.48 \\
0.00 \\
27.78 \\
0.25 \\
0.29 \\
10.44 \\
5.07 \\
0.34 \\
99.64 \\
0.51\end{array}$ & $\begin{array}{r}55.50 \\
0.00 \\
27.92 \\
0.20 \\
0.23 \\
10.41 \\
5.19 \\
0.35 \\
99.80 \\
0.41\end{array}$ & $\begin{array}{r}56.32 \\
0.01 \\
27.41 \\
0.35 \\
0.19 \\
9.84 \\
5.61 \\
0.42 \\
100.15 \\
0.50\end{array}$ & $\begin{array}{r}55.44 \\
0.03 \\
28.17 \\
0.19 \\
0.31 \\
10.38 \\
5.29 \\
0.30 \\
100.11 \\
0.48\end{array}$ & $\begin{array}{r}54.77 \\
0.00 \\
28.11 \\
0.32 \\
0.17 \\
10.71 \\
5.12 \\
0.35 \\
99.55 \\
0.46\end{array}$ & $\begin{array}{r}50.92 \\
0.00 \\
31.05 \\
0.54 \\
0.12 \\
14.24 \\
3.34 \\
0.17 \\
100.38 \\
0.61\end{array}$ & $\begin{array}{r}49.34 \\
0.02 \\
32.15 \\
0.51 \\
0.10 \\
15.31 \\
2.82 \\
0.13 \\
100.37 \\
0.55\end{array}$ \\
\hline $\begin{array}{l}\text { atoms } / 8 \\
\text { Si } \\
\mathrm{Ti} \\
\mathrm{Al} \\
\mathrm{Fe} 3+ \\
\mathrm{Fe} 2+ \\
\mathrm{Ca} \\
\mathrm{Na} \\
\mathrm{K} \\
\text { tot }\end{array}$ & $\begin{array}{l}2.1774 \\
0.0010 \\
1.7992 \\
0.0234 \\
0.0021 \\
0.8310 \\
0.1710 \\
0.0047 \\
5.0098\end{array}$ & $\begin{array}{l}2.3231 \\
0.0000 \\
1.6563 \\
0.0206 \\
0.0084 \\
0.6787 \\
0.3075 \\
0.0157 \\
5.0104\end{array}$ & $\begin{array}{l}2.1347 \\
0.0000 \\
1.8464 \\
0.0190 \\
0.0002 \\
0.8772 \\
0.1272 \\
0.0023 \\
5.0069\end{array}$ & $\begin{array}{l}2.1874 \\
0.0000 \\
1.7938 \\
0.0188 \\
0.0060 \\
0.8166 \\
0.1822 \\
0.0041 \\
5.0088\end{array}$ & $\begin{array}{l}2.1373 \\
0.0017 \\
1.8485 \\
0.0142 \\
0.0056 \\
0.8604 \\
0.1363 \\
0.0018 \\
5.0057\end{array}$ & $\begin{array}{l}2.15 \\
0.00 \\
1.82 \\
0.01 \\
0.00 \\
0.84 \\
0.15 \\
0.00\end{array}$ & $\begin{array}{l}0.00 \\
1.81 \\
0.01 \\
0.00 \\
0.83 \\
0.16 \\
0.00\end{array}$ & $\begin{array}{l}2.2089 \\
0.0024 \\
1.7711 \\
0.0200 \\
0.0020 \\
0.7945 \\
0.2044 \\
0.0041 \\
5.0074\end{array}$ & $\begin{array}{l}2.3666 \\
0.0024 \\
1.6084 \\
0.0250 \\
0.0056 \\
0.6319 \\
0.3593 \\
0.0146\end{array}$ & $\begin{array}{l}0.0 \\
1.6 \\
0.0 \\
0.0 \\
0.6 \\
0.3 \\
0.0 \\
5.0\end{array}$ & $\begin{array}{l}1.5 \\
0.0 \\
0.0 \\
0.5 \\
0.5 \\
0.0\end{array}$ & $\begin{array}{l}1.4 \\
0.0 \\
0.0 \\
0.5 \\
0.4 \\
0.0\end{array}$ & $\begin{array}{l}1 \\
0 . \\
0 \\
0 \\
0\end{array}$ & $\begin{array}{l}1 \\
3 \\
0 \\
8 \\
0 \\
4 \\
5 \\
1 \\
3\end{array}$ & $\begin{array}{l}0 . \\
1 . \\
0 . \\
0 . \\
0 . \\
0 . \\
0 .\end{array}$ & & & 4 \\
\hline$A t$ & $\begin{array}{l}0.8 \\
0.1 \\
0.0\end{array}$ & 0.3 & 0.12 & 0.1 & 13 & $\begin{array}{l}0.1 \\
0.0\end{array}$ & -10 & $\begin{array}{l}0.2 \\
0.0\end{array}$ & 3 & $\begin{array}{l}0 \\
0\end{array}$ & 1.4 & 3 & & & & & & \\
\hline
\end{tabular}




\begin{tabular}{|c|c|c|c|c|c|c|c|c|c|c|c|c|c|c|c|c|c|c|}
\hline $\begin{array}{l}\text { Strat\# } \\
\text { Field\# } \\
\text { Grain } \\
\text { Anal\# }\end{array}$ & $\begin{array}{r}\text { AMs- } 103 \\
85 \mathrm{cns} 23 \\
\text { pl6c } \\
55\end{array}$ & $\begin{array}{r}\text { AMS - } 103 \\
85 \text { cns23 } \\
\text { pl6r } \\
56\end{array}$ & $\begin{array}{r}\text { AMS-A03 } \\
85 \text { ens23 } \\
\text { pl7c } \\
57\end{array}$ & $\begin{array}{r}\text { AMS-A03 } \\
85 \text { crs23 } \\
\text { pl7r } \\
58\end{array}$ & $\begin{array}{r}\text { A4S-A03 } \\
85 \text { ens } 23 \\
\text { plBg } \\
59\end{array}$ & $\begin{array}{r}A 03 \\
n s 23 \\
\text { pl } 15 c \\
53\end{array}$ & $\begin{array}{r}\text { AMS-103 } \\
85 \text { ens23 } \\
\text { PL.pl5r } \\
54\end{array}$ & $\begin{array}{r}\text { AMS- } 104 \\
85 \mathrm{cns} 22 \\
\text { p11c } \\
31\end{array}$ & $\begin{array}{r}\text { AMs-104 } \\
85 \mathrm{cns} 22 \\
\text { pl } 1 \mathrm{r} \\
32\end{array}$ & $\begin{array}{r}\text { AMs-A04 } \\
85 \mathrm{cns} 22 \\
\mathrm{pl} 2 \mathrm{c} \\
33\end{array}$ & $\begin{array}{r}\text { AMS-A04 } \\
85 \text { ens22 } \\
\text { pl } 2 r \\
34\end{array}$ & $\begin{array}{r}\text { AMS - A04 } \\
85 \mathrm{cns} 22 \\
\mathrm{pl} 3 \mathrm{c} \\
35\end{array}$ & $\begin{array}{r}\text { AMS-A04 } \\
85 \text { ens22 } \\
\text { pl } 3 r \\
36\end{array}$ & $\begin{array}{l}\text { AMS-A } \\
85 \mathrm{cns} \\
\text { pla }\end{array}$ & $\begin{array}{r}\text { rs- }-104 \\
5 \mathrm{cns} 22 \\
\mathrm{pl} 4 \mathrm{r} \\
38\end{array}$ & $\begin{array}{l}2 \\
6 \\
0 \\
0\end{array}$ & & $\begin{array}{l}104 \\
22 \\
5 r \\
41\end{array}$ \\
\hline $\begin{array}{l}\text { wty oxide } \\
\text { SiO2 } \\
\text { rio2 } \\
\text { Al203 } \\
\text { Fe2O3 } \\
\text { FeO } \\
\text { CaO } \\
\text { Ne2O } \\
\text { K2O } \\
\text { tot } \\
\text { FeO meas. }\end{array}$ & $\begin{array}{r}56.20 \\
0.04 \\
27.17 \\
0.46 \\
0.07 \\
9.86 \\
5.63 \\
0.34 \\
99.77 \\
0.48\end{array}$ & $\begin{array}{r}56.07 \\
0.03 \\
27.46 \\
0.37 \\
0.19 \\
9.97 \\
5.52 \\
0.36 \\
99.97 \\
0.52\end{array}$ & $\begin{array}{r}50.92 \\
0.07 \\
30.71 \\
0.31 \\
0.18 \\
13.34 \\
3.80 \\
0.16 \\
99.49 \\
0.46\end{array}$ & $\begin{array}{r}55.34 \\
0.07 \\
28.41 \\
0.27 \\
0.22 \\
10.68 \\
5.15 \\
0.35 \\
100.50 \\
0.47\end{array}$ & $\begin{array}{r}54.70 \\
0.07 \\
28.35 \\
0.29 \\
0.34 \\
10.65 \\
5.08 \\
0.33 \\
99.81 \\
0.60\end{array}$ & $\begin{array}{r}46.54 \\
0.00 \\
33.82 \\
0.52 \\
0.07 \\
17.50 \\
1.54 \\
0.04 \\
100.03 \\
0.54\end{array}$ & $\begin{array}{r}50.35 \\
0.07 \\
31.12 \\
0.65 \\
0.05 \\
14.39 \\
3.30 \\
0.11 \\
100.04 \\
0.63\end{array}$ & $\begin{array}{r}46.06 \\
0.03 \\
34.21 \\
0.54 \\
0.17 \\
17.89 \\
1.23 \\
0.03 \\
100.16 \\
0.66\end{array}$ & $\begin{array}{r}51.96 \\
0.00 \\
29.11 \\
0.72 \\
0.24 \\
12.52 \\
4.11 \\
0.15 \\
98.81 \\
0.89\end{array}$ & $\begin{array}{r}46.84 \\
0.04 \\
33.67 \\
0.66 \\
0.00 \\
17.59 \\
1.63 \\
0.03 \\
100.46 \\
0.59\end{array}$ & $\begin{array}{r}52.27 \\
0.04 \\
29.71 \\
0.70 \\
0.31 \\
12.89 \\
3.96 \\
0.11 \\
99.99 \\
0.94\end{array}$ & $\begin{array}{r}45.27 \\
0.01 \\
34.56 \\
0.46 \\
0.18 \\
18.23 \\
1.03 \\
0.03 \\
99.78 \\
0.60\end{array}$ & $\begin{array}{r}50.97 \\
0.16 \\
30.58 \\
0.89 \\
0.04 \\
13.83 \\
3.64 \\
0.11 \\
100.22 \\
0.84\end{array}$ & $\begin{array}{r}47.97 \\
0.04 \\
32.70 \\
0.56 \\
0.24 \\
16.09 \\
2.22 \\
0.07 \\
99.89 \\
0.74\end{array}$ & $\begin{array}{r}51.78 \\
0.07 \\
30.00 \\
0.78 \\
0.10 \\
13.38 \\
3.79 \\
0.11 \\
100.01 \\
0.80\end{array}$ & $\begin{array}{r}47.30 \\
0.11 \\
33.27 \\
0.69 \\
0.01 \\
16.88 \\
1.89 \\
0.05 \\
100.20 \\
0.63\end{array}$ & $\begin{array}{r}47.93 \\
0.04 \\
32.97 \\
0.49 \\
0.26 \\
16.33 \\
2.07 \\
0.04 \\
100.13 \\
0.70\end{array}$ & $\begin{array}{r}51.26 \\
0.07 \\
30.68 \\
0.58 \\
0.27 \\
13.77 \\
3.48 \\
0.09 \\
100.20 \\
0.79\end{array}$ \\
\hline $\begin{array}{l}\text { atons/8 } \\
\text { Si } \\
\text { Ti } \\
\text { Al } \\
\text { Fe3+ } \\
\text { Fe2+ } \\
\text { Ca } \\
\text { Na } \\
\text { K } \\
\text { tot }\end{array}$ & $\begin{array}{l}2.5380 \\
0.0014 \\
1.4465 \\
0.0155 \\
0.0026 \\
0.4771 \\
0.4930 \\
0.0196 \\
4.9937\end{array}$ & $\begin{array}{l}2.5279 \\
0.0010 \\
1.4595 \\
0.0126 \\
0.0070 \\
0.4816 \\
0.4826 \\
0.0207 \\
4.9930\end{array}$ & $\begin{array}{l}2.3315 \\
0.0024 \\
1.6578 \\
0.0107 \\
0.0069 \\
0.6545 \\
0.3374 \\
0.0093 \\
5.0105\end{array}$ & $\begin{array}{l}2.4861 \\
0.0024 \\
1.5047 \\
0.0092 \\
0.0084 \\
0.5141 \\
0.4486 \\
0.0201 \\
4.9935\end{array}$ & $\begin{array}{l}2.4767 \\
0.0024 \\
1.5133 \\
0.0100 \\
0.0127 \\
0.5167 \\
0.4460 \\
0.0191 \\
4.9968\end{array}$ & $\begin{array}{l}2.1446 \\
0.0000 \\
1.8373 \\
0.0181 \\
0.0027 \\
0.8641 \\
0.1376 \\
0.0024 \\
5.0067\end{array}$ & $\begin{array}{l}2.3010 \\
0.0024 \\
1.6767 \\
0.0223 \\
0.0018 \\
0.7047 \\
0.2924 \\
0.0064 \\
5.0077\end{array}$ & $\begin{array}{l}2.1226 \\
0.0010 \\
1.8586 \\
0.0187 \\
0.0067 \\
0.8834 \\
0.1099 \\
0.0018 \\
5.0028\end{array}$ & $\begin{array}{l}2.3939 \\
0.0000 \\
1.5812 \\
0.0249 \\
0.0094 \\
0.6181 \\
0.3672 \\
0.0088 \\
5.0035\end{array}$ & $\begin{array}{l}2.1508 \\
0.0014 \\
1.8227 \\
0.0227 \\
0.0000 \\
0.8655 \\
0.1451 \\
0.0018 \\
5.0099\end{array}$ & $\begin{array}{l}0.0 \\
1.5 \\
0.0 \\
0.0 \\
0.0 \\
0.3 \\
0.0 \\
4.9\end{array}$ & $\begin{array}{l}0.8 \\
1.8 \\
0.0 \\
0.0 \\
0.5 \\
0.1 \\
0.0 \\
5.0\end{array}$ & $\begin{array}{l}50 \\
55 \\
55 \\
55 \\
6 \\
60 \\
20 \\
20 \\
44 \\
14\end{array}$ & $\begin{array}{l}0 . \\
1 . \\
0 . \\
0.0 \\
0 . \\
0 . \\
0 . \\
5 .\end{array}$ & $\begin{array}{l}78 \\
24 \\
55 \\
57 \\
38 \\
66 \\
51 \\
13 \\
13\end{array}$ & $\begin{array}{l}1 . \\
0 . \\
0 . \\
0 . \\
0 . \\
0 . \\
5 .\end{array}$ & & $\begin{array}{l}6 \\
4 \\
66 \\
76 \\
37 \\
17 \\
72\end{array}$ \\
\hline$A n$ & $\begin{array}{l}0.4821 \\
0.4981 \\
0.0198\end{array}$ & $\begin{array}{l}0.48 \\
0.49\end{array}$ & $\begin{array}{l}0.6 \\
0.3\end{array}$ & $\begin{array}{l}0.52 \\
0.45 \\
0.02\end{array}$ & $\begin{array}{l}0.5263 \\
0.4543 \\
0.0194\end{array}$ & $\begin{array}{l}0.8 \\
0.1 \\
0.0\end{array}$ & $\begin{array}{l}0.7 \\
0.2\end{array}$ & $\begin{array}{l}0.8 \\
0.1 \\
0.1\end{array}$ & $\begin{array}{l}0 \\
0 \\
0\end{array}$ & $\begin{array}{l}0.8 \\
0 . \\
0 .\end{array}$ & $\begin{array}{l}85 \\
50 \\
65\end{array}$ & $\begin{array}{l}0 . \\
0 . \\
0 .\end{array}$ & $\begin{array}{l}31 \\
06 \\
64\end{array}$ & 0. & 0. & & & \\
\hline
\end{tabular}




\begin{tabular}{|c|c|c|c|c|c|c|c|c|c|c|c|c|c|c|c|c|c|c|}
\hline $\begin{array}{l}\text { Strat\# } \\
\text { Field\# } \\
\text { Grain } \\
\text { Anal\# }\end{array}$ & $\begin{array}{r}\text { AMS-A04 } \\
85 \text { cns22 } \\
\text { pl6g } \\
43\end{array}$ & $\begin{array}{r}\text { AF-08 } \\
85 \mathrm{cns08} \\
\text { pl 1c } \\
132\end{array}$ & $\begin{array}{r}\text { Af-08 } \\
85 \mathrm{cns} 08 \\
\text { plir } \\
133\end{array}$ & $\begin{array}{r}\text { AF-08 } \\
85 \mathrm{cns08} \\
p / 2 r \\
135\end{array}$ & $\begin{array}{r}\text { AF-08 } \\
85 \mathrm{cns08} \\
\text { pl2sc } \\
134\end{array}$ & $\begin{array}{r}\text { AF-08 } \\
85 c n s 08 \\
p \mid 3 c \\
136\end{array}$ & $\begin{array}{r}\text { Af- } 08 \\
85 c n s 08 \\
p l 3 r \\
137\end{array}$ & $\begin{array}{r}\text { AF-08 } \\
85 \mathrm{cns08} \\
p / 4 \mathrm{c} \\
138\end{array}$ & $\begin{array}{r}\text { AF-08 } \\
85 \mathrm{cns08} \\
\text { pl } 4 \mathrm{r} \\
139\end{array}$ & $\begin{array}{r}\text { AF-08 } \\
85 \mathrm{cns08} \\
\mathrm{p} / 5 \mathrm{c} \\
140\end{array}$ & $\begin{array}{r}\text { AF-08 } \\
85 \mathrm{cns08} \\
p 15 \mathrm{~m} \\
141\end{array}$ & $\begin{array}{r}\text { Af }-08 \\
85 \mathrm{cns08} \\
\mathrm{p} 15 \mathrm{r} \\
142\end{array}$ & $\begin{array}{r}\text { AF-08 } \\
85 \mathrm{cns08} \\
\text { pl6c } \\
143\end{array}$ & $\begin{array}{r}\text { AF-08 } \\
85 \mathrm{cns08} \\
\text { pl6m } \\
144\end{array}$ & $\begin{array}{r}A F-08 \\
85 \mathrm{cns08} \\
p / 6 r \\
145\end{array}$ & $\begin{array}{r}\text { AF-08 } \\
85 \mathrm{cns} 08 \\
p l 7 g \\
146\end{array}$ & $\begin{array}{r}A F-08 \\
85 \mathrm{cns} 08 \\
p 18 g \\
147\end{array}$ & $\begin{array}{r}\text { Af }-08 \\
\text { 85cns08 } \\
p 199 \\
148\end{array}$ \\
\hline $\begin{array}{l}\text { wt\% oxide } \\
\text { Si02 } \\
\text { TiO02 } \\
\text { Al203 } \\
\text { Fe203 } \\
\text { FeO } \\
\text { CaO } \\
\text { Na20 } \\
\text { K20 } \\
\text { tot } \\
\text { FeO meas. }\end{array}$ & $\begin{array}{r}56.80 \\
0.05 \\
26.50 \\
0.90 \\
0.21 \\
9.53 \\
5.78 \\
0.36 \\
100.13 \\
1.02\end{array}$ & $\begin{array}{r}57.19 \\
0.03 \\
26.78 \\
0.28 \\
0.27 \\
8.95 \\
6.07 \\
0.39 \\
99.96 \\
0.52\end{array}$ & $\begin{array}{r}57.54 \\
0.00 \\
26.81 \\
0.29 \\
0.23 \\
9.04 \\
6.06 \\
0.41 \\
100.38 \\
0.49\end{array}$ & $\begin{array}{r}50.06 \\
0.07 \\
31.52 \\
0.70 \\
0.01 \\
14.86 \\
3.06 \\
0.16 \\
100.44 \\
0.64\end{array}$ & $\begin{array}{r}58.14 \\
0.04 \\
26.83 \\
0.30 \\
0.22 \\
8.92 \\
6.14 \\
0.45 \\
101.04 \\
0.49\end{array}$ & $\begin{array}{r}56.23 \\
0.03 \\
28.00 \\
0.28 \\
0.18 \\
10.32 \\
5.42 \\
0.33 \\
100.79 \\
0.43\end{array}$ & $\begin{array}{r}58.78 \\
0.07 \\
25.99 \\
0.29 \\
0.28 \\
8.32 \\
6.16 \\
0.50 \\
100.39 \\
0.54\end{array}$ & $\begin{array}{r}54.25 \\
0.00 \\
29.18 \\
0.23 \\
0.23 \\
11.65 \\
4.67 \\
0.27 \\
100.48 \\
0.44\end{array}$ & $\begin{array}{r}59.07 \\
0.04 \\
25.61 \\
0.18 \\
0.29 \\
7.86 \\
6.36 \\
0.54 \\
99.95 \\
0.45\end{array}$ & $\begin{array}{r}56.60 \\
0.00 \\
27.70 \\
0.38 \\
0.20 \\
10.01 \\
5.66 \\
0.36 \\
100.91 \\
0.54\end{array}$ & $\begin{array}{r}57.02 \\
0.03 \\
27.12 \\
0.17 \\
0.30 \\
9.39 \\
5.69 \\
0.38 \\
100.10 \\
0.45\end{array}$ & $\begin{array}{r}54.02 \\
0.02 \\
29.27 \\
0.32 \\
0.28 \\
11.85 \\
4.53 \\
0.23 \\
100.52 \\
0.57\end{array}$ & $\begin{array}{r}57.79 \\
0.07 \\
26.62 \\
0.39 \\
0.20 \\
8.96 \\
5.99 \\
0.48 \\
100.50 \\
0.55\end{array}$ & $\begin{array}{r}53.59 \\
0.05 \\
29.52 \\
0.30 \\
0.22 \\
12.00 \\
4.44 \\
0.32 \\
100.44 \\
0.49\end{array}$ & $\begin{array}{r}49.42 \\
0.03 \\
32.66 \\
0.21 \\
0.44 \\
15.38 \\
2.53 \\
0.10 \\
100.77 \\
0.63\end{array}$ & $\begin{array}{r}50.36 \\
0.05 \\
31 . .50 \\
0.52 \\
0.16 \\
14.50 \\
3 . .23 \\
0.13 \\
100.45 \\
0.63\end{array}$ & $\begin{array}{r}53.93 \\
0.04 \\
29.32 \\
0.37 \\
0.30 \\
11.80 \\
4.59 \\
0.25 \\
100.60 \\
0.63\end{array}$ & $\begin{array}{r}54 . \\
0 . \\
28 . \\
0 . \\
0 . \\
11 . \\
5 . \\
0 . \\
100 . \\
0 .\end{array}$ \\
\hline $\begin{array}{l}\text { atons } / 8 \\
\mathrm{Si} \\
\mathrm{Ti} \\
\mathrm{Al} \\
\mathrm{Fe}+ \\
\mathrm{Fe}+\mathbf{+} \\
\mathrm{Ca} \\
\mathrm{Na} \\
\mathrm{K} \\
\text { tot }\end{array}$ & $\begin{array}{l}2.5609 \\
0.0017 \\
1.4086 \\
0.0305 \\
0.0080 \\
0.4604 \\
0.5053 \\
0.0207 \\
4.9961\end{array}$ & $\begin{array}{l}2.5712 \\
0.0010 \\
1.4194 \\
0.0094 \\
0.0102 \\
0.4312 \\
0.5292 \\
0.0224 \\
4.9939\end{array}$ & $\begin{array}{l}2.5756 \\
0.0000 \\
1.4148 \\
0.0096 \\
0.0087 \\
0.4336 \\
0.5260 \\
0.0234 \\
4.9917\end{array}$ & $\begin{array}{l}2.2820 \\
0.0024 \\
1.6940 \\
0.0240 \\
0.0004 \\
0.7258 \\
0.2705 \\
0.0093 \\
5.0085\end{array}$ & $\begin{array}{l}2.5841 \\
0.0013 \\
1.4059 \\
0.0101 \\
0.0082 \\
0.4248 \\
0.5292 \\
0.0255 \\
4.9890\end{array}$ & $\begin{array}{l}2.5144 \\
0.0010 \\
1.4761 \\
0.0095 \\
0.0066 \\
0.4945 \\
0.4700 \\
0.0188 \\
4.9909\end{array}$ & $\begin{array}{l}2.6229 \\
0.0023 \\
1.3672 \\
0.0099 \\
0.0103 \\
0.3978 \\
0.5330 \\
0.0285 \\
4.9719\end{array}$ & $\begin{array}{l}2.4430 \\
0.0000 \\
1.5491 \\
0.0079 \\
0.0087 \\
0.5621 \\
0.4078 \\
0.0155 \\
4.9941\end{array}$ & $\begin{array}{l}2.6430 \\
0.0013 \\
1.3509 \\
0.0061 \\
0.0107 \\
0.3768 \\
0.5518 \\
0.0308 \\
4.9715\end{array}$ & $\begin{array}{l}2.5285 \\
0.0000 \\
1.4589 \\
0.0126 \\
0.0075 \\
0.4792 \\
0.4903 \\
0.0205 \\
4.9975\end{array}$ & $\begin{array}{l}2 \\
0 \\
0 \\
7 \\
2 \\
6 \\
2 \\
8 \\
7\end{array}$ & $\begin{array}{l}2.4341 \\
0.0007 \\
1.5549 \\
0.0110 \\
0.0105 \\
0.5721 \\
0.3958 \\
0.0132 \\
4.9923\end{array}$ & $\begin{array}{l}0.0 \\
1.4 \\
0.0 \\
0.0 \\
0.4 \\
0.5 \\
0.0\end{array}$ & $\begin{array}{l}0 . \\
1 . \\
0 . \\
0 . \\
0 .\end{array}$ & $\begin{array}{l}3 \\
0 \\
5 \\
2 \\
7 \\
4 \\
8 \\
8 \\
7\end{array}$ & $\begin{array}{l}0 \\
17 \\
9 \\
9 \\
1 \\
1 \\
10 \\
0\end{array}$ & & $\begin{array}{l}0 \\
5\end{array}$ \\
\hline $\begin{array}{l}\text { An } \\
\text { Ab } \\
\text { or }\end{array}$ & $\begin{array}{l}0.4667 \\
0.5123 \\
0.0210\end{array}$ & $\begin{array}{l}0.4388 \\
0.5385 \\
0.0228\end{array}$ & $\begin{array}{l}0.44 \\
0.53 \\
0.02\end{array}$ & $\begin{array}{l}0.7 \\
0.2 \\
0.0\end{array}$ & 0.5 & $\begin{array}{l}0.5 \\
0.4 \\
0.0\end{array}$ & 0.5 & $\begin{array}{l}0.5 \\
0.4 \\
0.0\end{array}$ & $\begin{array}{l}8 \\
1 \\
1\end{array}$ & $\begin{array}{l}0.4 \\
0.4 \\
0.0\end{array}$ & 3 & & $\begin{array}{l}8 \\
1 \\
1\end{array}$ & & & $\begin{array}{l}3 \\
1 \\
6\end{array}$ & & \\
\hline
\end{tabular}




\begin{tabular}{|c|c|c|c|c|c|c|c|c|c|c|c|c|c|c|c|c|c|c|}
\hline$\#$ & $\begin{array}{r}\text { Af }-09 \\
85 n c s 09 \\
\text { pl 1c } \\
149\end{array}$ & $\begin{array}{r}\text { AF-09 } \\
85 \mathrm{cns} 09 \\
\text { Pl1r } \\
150\end{array}$ & $\begin{array}{r}A F-09 \\
85 \mathrm{cns} 09 \\
\text { pl } 2 \mathrm{c} \\
151\end{array}$ & $\begin{array}{r}\text { AF-09 } \\
85 \mathrm{cns09} \\
\text { pl2r } \\
152\end{array}$ & $\begin{array}{r}A F-09 \\
85 \mathrm{cns} 09 \\
p / 3 \mathrm{c} \\
153\end{array}$ & $\begin{array}{r}\text { AF-09 } \\
85 \text { ens09 } \\
\text { pl3r } \\
154\end{array}$ & $\begin{array}{r}\text { AF-09 } \\
85 \text { ens09 } \\
\text { Pl } 4 c \\
155\end{array}$ & $\begin{array}{r}\text { Af-09 } \\
85 \mathrm{cns} 09 \\
\text { Pl } 4 r \\
156\end{array}$ & $\begin{array}{r}\text { AF }-09 \\
85 c n s 09 \\
\text { pl } 4 r_{2} \\
157\end{array}$ & $\begin{array}{r}\text { AF-09 } \\
85 c n s 09 \\
\text { Pl5c } \\
158\end{array}$ & $\begin{array}{r}\text { AF-09 } \\
85 \text { ens09 } \\
\text { Pl5r } \\
159\end{array}$ & $\begin{array}{r}\text { Af }-09 \\
85 \mathrm{cns} 09 \\
p l 6 c \\
160\end{array}$ & $\begin{array}{r}\text { AF- } \\
85 \mathrm{cns} \\
\mathrm{p!}\end{array}$ & $\begin{array}{r}\text { Af }-09 \\
85 \mathrm{cns} 09 \\
\text { Pl7g } \\
162\end{array}$ & $\begin{array}{r}\text { AF-09 } \\
85 \text { ens09 } \\
\text { pl7g } \\
163\end{array}$ & $\begin{array}{r}s p-02 \\
s p-r s 2 \\
p l 1 c \\
164\end{array}$ & $\begin{array}{r}\mathbf{s p} \\
\mathbf{s p -} \\
\mathbf{p}\end{array}$ & $\begin{array}{r}s p-02 \\
\text { sp-rs2 } \\
\text { pl2c } \\
166\end{array}$ \\
\hline $\begin{array}{l}\text { wty oxide } \\
\text { SiO2 } \\
\text { TiO2 } \\
\text { Al203 } \\
\text { Fe203 } \\
\text { FeO } \\
\text { CaO } \\
\text { Na2O } \\
\text { K2O } \\
\text { tot } \\
\text { FeO meas. }\end{array}$ & $\begin{array}{r}54.25 \\
0.00 \\
29.57 \\
0.04 \\
0.40 \\
11.64 \\
4.61 \\
0.29 \\
100.80 \\
0.44\end{array}$ & $\begin{array}{r}60.32 \\
0.00 \\
25.16 \\
0.08 \\
0.34 \\
6.98 \\
6.82 \\
0.81 \\
100.51 \\
0.41\end{array}$ & $\begin{array}{r}54.10 \\
0.07 \\
29.14 \\
0.22 \\
0.30 \\
11.47 \\
4.66 \\
0.28 \\
100.23 \\
0.49\end{array}$ & $\begin{array}{r}60.41 \\
0.07 \\
25.04 \\
0.23 \\
0.24 \\
6.94 \\
6.88 \\
0.81 \\
100.62 \\
0.45\end{array}$ & $\begin{array}{r}55.40 \\
0.07 \\
28.39 \\
0.12 \\
0.19 \\
10.63 \\
5.12 \\
0.33 \\
100.25 \\
0.30\end{array}$ & $\begin{array}{r}60.11 \\
0.04 \\
24.79 \\
0.29 \\
0.19 \\
7.09 \\
6.70 \\
0.82 \\
100.03 \\
0.45\end{array}$ & $\begin{array}{r}56.05 \\
0.03 \\
28.19 \\
0.11 \\
0.34 \\
10.19 \\
5.36 \\
0.39 \\
100.66 \\
0.44\end{array}$ & $\begin{array}{r}57.00 \\
0.04 \\
27.41 \\
0.30 \\
0.18 \\
9.61 \\
5.77 \\
0.45 \\
100.76 \\
0.45\end{array}$ & $\begin{array}{r}57.74 \\
0.03 \\
26.78 \\
0.10 \\
0.36 \\
8.85 \\
5.88 \\
0.53 \\
100.27 \\
0.45\end{array}$ & $\begin{array}{r}49.58 \\
0.00 \\
32.68 \\
0.28 \\
0.30 \\
15.42 \\
2.70 \\
0.13 \\
101.09 \\
0.55\end{array}$ & $\begin{array}{r}58.89 \\
0.07 \\
26.16 \\
0.00 \\
0.40 \\
7.73 \\
6.39 \\
0.69 \\
100.33 \\
0.40\end{array}$ & $\begin{array}{r}56.23 \\
0.03 \\
27.95 \\
0.00 \\
0.43 \\
10.13 \\
5.15 \\
0.36 \\
100.28 \\
0.43\end{array}$ & $\begin{array}{r}55.45 \\
0.04 \\
28.30 \\
0.13 \\
0.32 \\
10.46 \\
5.16 \\
0.38 \\
100.23 \\
0.43\end{array}$ & $\begin{array}{r}56.59 \\
0.00 \\
28.22 \\
0.04 \\
0.47 \\
10.20 \\
5.22 \\
0.44 \\
101.17 \\
0.50\end{array}$ & $\begin{array}{r}55.69 \\
0.07 \\
27.84 \\
0.24 \\
0.31 \\
10.13 \\
5.24 \\
0.46 \\
00.07\end{array}$ & $\begin{array}{r}55.33 \\
0.00 \\
27.78 \\
0.21 \\
0.30 \\
10.10 \\
5.41 \\
0.33 \\
99.46 \\
0.40\end{array}$ & $\begin{array}{r}57.86 \\
0.07 \\
26.75 \\
0.37 \\
0.13 \\
9.09 \\
6.06 \\
0.34 \\
100.67 \\
0.46\end{array}$ & $\begin{array}{r}55.48 \\
0.04 \\
28.07 \\
0.35 \\
0.08 \\
10.57 \\
5.35 \\
0.26 \\
100.21\end{array}$ \\
\hline $\begin{array}{l}\text { atoms } / 8 \\
\text { si } \\
\text { Ti } \\
\text { Ai } \\
\text { Fe3+ } \\
\text { Fe2+ } \\
\mathrm{Ca} \\
\mathrm{Na}\end{array}$ & $\begin{array}{l}2.4343 \\
0.0000 \\
1.5643 \\
0.0014 \\
0.0151 \\
0.5597 \\
0.4011 \\
0.0166\end{array}$ & $\begin{array}{l}2.6796 \\
0.0000 \\
1.3177 \\
0.0027 \\
0.0126 \\
0.3323 \\
0.5875 \\
0.0459\end{array}$ & $\begin{array}{l}2.4420 \\
0.0024 \\
1.5507 \\
0.0073 \\
0.0112 \\
0.5548 \\
0.4079 \\
0.0161 \\
4.9923\end{array}$ & $\begin{array}{l}2.6818 \\
0.0023 \\
1.3105 \\
0.0076 \\
0.0091 \\
0.3301 \\
0.5922 \\
0.0459\end{array}$ & $\begin{array}{l}2.4909 \\
0.0024 \\
1.5049 \\
0.0042 \\
0.0071 \\
0.5121 \\
0.4464 \\
0.0189 \\
4.9869\end{array}$ & $\begin{array}{l}2.6848 \\
0.0013 \\
1.3054 \\
0.0098 \\
0.0070 \\
0.3393 \\
0.5803 \\
0.0467 \\
4.9746\end{array}$ & $\begin{array}{l}0.00 \\
0.00 \\
1.48 \\
0.00 \\
0.01 \\
0.48 \\
0.46 \\
0.02 \\
4.95\end{array}$ & $\begin{array}{l}1.4 \\
0.0 \\
0.0 \\
0.4 \\
0.4 \\
0.0 \\
4.9\end{array}$ & $\begin{array}{l}2.2 \\
0.0 \\
1.4 \\
0.0 \\
0.0 \\
0.4 \\
0.5 \\
0.0 \\
4.9\end{array}$ & $\begin{array}{l}1.7 \\
0.0 \\
0.0 \\
0.7 \\
0.2 \\
0.0 \\
5.0\end{array}$ & $\begin{array}{l}2.00 \\
0.00 \\
1.37 \\
0.00 \\
0.01 \\
0.36 \\
0.55 \\
0.03 \\
4.97\end{array}$ & $\begin{array}{l}0 \\
0 \\
9 \\
1 \\
0 \\
8 \\
9 \\
16\end{array}$ & $\begin{array}{l}0.0 \\
1.5 \\
0.0 \\
0.0 \\
0.5 \\
0.4 \\
0.0 \\
4.9\end{array}$ & $\begin{array}{l}3 \\
0 \\
5 \\
2 \\
4 \\
4 \\
4 \\
0\end{array}$ & $\begin{array}{l}77 \\
24 \\
31 \\
31 \\
6 \\
5 \\
32 \\
5\end{array}$ & & & \\
\hline & $\begin{array}{l}0.5 \\
0.4 \\
0.0\end{array}$ & $\begin{array}{l}0.3 \\
0.6 \\
0.0\end{array}$ & $\begin{array}{l}0.5 \\
0.4\end{array}$ & 0.6 & 0.4 & $\begin{array}{l}0.3 \\
0.6\end{array}$ & $\begin{array}{l}0 \\
0\end{array}$ & ? & $\begin{array}{l}0 \\
0\end{array}$ & & $\begin{array}{l}0 \\
0\end{array}$ & & & & & & & \\
\hline
\end{tabular}




\begin{tabular}{|c|c|c|c|c|c|c|c|c|c|c|c|c|c|c|c|c|c|c|}
\hline $\begin{array}{l}\text { Strat\# } \\
\text { Field\# } \\
\text { Grain }\end{array}$ & $\begin{array}{r}s p-02 \\
s p-r s 2 \\
p l 2 r \\
167\end{array}$ & $\begin{array}{r}s p-02 \\
\text { sp-rs2 } \\
\text { pl3c } \\
168\end{array}$ & $\begin{array}{r}s p-02 \\
\text { sp-rs2 } \\
p l 3 r \\
169\end{array}$ & $\begin{array}{r}s p-02 \\
s p-r 82 \\
p l 4 c \\
170\end{array}$ & $\begin{array}{r}s p-02 \\
8 p-r s 2 \\
p l 4 r \\
171\end{array}$ & $\begin{array}{r}s p-02 \\
s p-r s 2 \\
p \mid 5 c \\
172\end{array}$ & $\begin{array}{r}\text { sp-02 } \\
\text { sp-rs2 } \\
\text { pl5r } \\
173\end{array}$ & $\begin{array}{r}s p-02 \\
\text { sp-rs2 } \\
\text { pl6c } \\
174\end{array}$ & $\begin{array}{r}\text { SP-02 } \\
\text { sp-rs2 } \\
\text { pl6r } \\
175\end{array}$ & $\begin{array}{r}\text { sp-02 } \\
8 p-r s 2 \\
p l 7 g \\
176\end{array}$ & $\begin{array}{r}\text { SP-02 } \\
\text { sp-r82 } \\
\text { pl8g } \\
177\end{array}$ & $\begin{array}{r}s p-02 \\
s p-r 82 \\
p 19 g \\
178\end{array}$ & $\begin{array}{r}\text { PF-38 } \\
85 \mathrm{cns} 38 \\
\text { Pl } 1 \mathrm{r} \\
120\end{array}$ & $\begin{array}{r}\text { PF }-38 \\
85 c n s 38 \\
\text { Pl } 18 c \\
119\end{array}$ & $\begin{array}{r}\text { PF-38 } \\
85 \text { ens38 } \\
\text { Pl } 2 c 1 \\
121\end{array}$ & $\begin{array}{r}\text { PF-38 } \\
85 \mathrm{cns} 38 \\
\text { pl } 2 \mathrm{c} 2\end{array}$ & $\begin{array}{r}\mathrm{PF} \\
\mathbf{p}\end{array}$ & \\
\hline $\begin{array}{l}\text { wtK oxide } \\
\text { si02 } \\
\text { Ti02 } \\
\text { Alzo3 } \\
\text { fe203 } \\
\text { FeO } \\
\text { CaO } \\
\text { Na20 } \\
\text { K20 } \\
\text { tot } \\
\text { feO meas. }\end{array}$ & $\begin{array}{r}55.74 \\
0.00 \\
27.82 \\
0.40 \\
0.09 \\
10.44 \\
5.45 \\
0.25 \\
100.19 \\
0.45\end{array}$ & $\begin{array}{r}53.81 \\
0.04 \\
28.70 \\
0.51 \\
0.00 \\
11.66 \\
4.84 \\
0.22 \\
99.78 \\
0.46\end{array}$ & $\begin{array}{r}56.53 \\
0.05 \\
27.24 \\
0.29 \\
0.29 \\
9.50 \\
5.75 \\
0.33 \\
99.98 \\
0.55\end{array}$ & $\begin{array}{r}56.96 \\
0.02 \\
26.81 \\
0.10 \\
0.31 \\
8.89 \\
6.01 \\
0.37 \\
99.47 \\
0.40\end{array}$ & $\begin{array}{r}56.91 \\
0.02 \\
26.64 \\
0.27 \\
0.16 \\
8.91 \\
6.15 \\
0.37 \\
99.43 \\
0.40\end{array}$ & $\begin{array}{r}55.85 \\
0.00 \\
27.70 \\
0.13 \\
0.25 \\
9.92 \\
5.55 \\
0.33 \\
99.73 \\
0.37\end{array}$ & $\begin{array}{r}57.23 \\
0.07 \\
26.93 \\
0.27 \\
0.21 \\
9.04 \\
6.09 \\
0.32 \\
100.17 \\
0.46\end{array}$ & $\begin{array}{r}55.02 \\
0.04 \\
28.32 \\
0.14 \\
0.28 \\
10.49 \\
5.23 \\
0.30 \\
99.82 \\
0.41\end{array}$ & $\begin{array}{r}56.64 \\
0.07 \\
26.73 \\
0.25 \\
0.24 \\
9.02 \\
5.92 \\
0.37 \\
99.25 \\
0.47\end{array}$ & $\begin{array}{r}54.13 \\
0.08 \\
28.62 \\
0.41 \\
0.18 \\
11.24 \\
4.84 \\
0.27 \\
99.77 \\
0.55\end{array}$ & $\begin{array}{r}55.09 \\
0.04 \\
28.51 \\
0.49 \\
0.24 \\
10.89 \\
5.24 \\
0.26 \\
100.76 \\
0.68\end{array}$ & $\begin{array}{r}54.70 \\
0.07 \\
28.32 \\
0.36 \\
0.23 \\
10.82 \\
5.08 \\
0.23 \\
99.82 \\
0.56\end{array}$ & $\begin{array}{r}49.28 \\
0.00 \\
32.79 \\
0.16 \\
0.24 \\
15.45 \\
2.75 \\
0.05 \\
100.72 \\
0.38\end{array}$ & $\begin{array}{r}54 . \\
0 . \\
28 . \\
0 . \\
0 . \\
12 . \\
3 . \\
0 . \\
100 . \\
0 .\end{array}$ & $\begin{array}{r}0 . \\
28 . \\
0 . \\
0 . \\
12 . \\
4 . \\
0 . \\
99 . \\
0 .\end{array}$ & $\begin{array}{r}50.66 \\
0.07 \\
31.33 \\
0.50 \\
0.25 \\
14.50 \\
2.96 \\
0.20 \\
100.47 \\
0.70\end{array}$ & $\begin{array}{r}53 \\
0 \\
30 \\
0 \\
0 \\
11 \\
4 \\
0 \\
100 \\
0\end{array}$ & $\begin{array}{r}53.83 \\
0.07 \\
29.77 \\
0.14 \\
0.37 \\
11.85 \\
4.59 \\
0.14 \\
0.74\end{array}$ \\
\hline $\begin{array}{l}\text { Ti } \\
\text { Ai } \\
\text { Fe3+ } \\
\text { Fe2+ } \\
\text { Ca } \\
\text { Na } \\
\text { K } \\
\text { tot }\end{array}$ & $\begin{array}{l}2.5096 \\
0.0000 \\
1.4767 \\
0.0137 \\
0.0033 \\
0.5037 \\
0.4758 \\
0.0144 \\
4.9971\end{array}$ & $\begin{array}{l}2.4439 \\
0.0014 \\
1.5367 \\
0.0175 \\
0.0000 \\
0.5674 \\
0.4262 \\
0.0127 \\
5.0059\end{array}$ & $\begin{array}{l}0.0017 \\
1.4455 \\
0.0100 \\
0.0107 \\
0.4582 \\
0.5019 \\
0.0100\end{array}$ & $\begin{array}{l}0.0007 \\
1.4263 \\
0.0034 \\
0.0117 \\
0.4299 \\
0.5259 \\
0.0213 \\
4.9894\end{array}$ & $\begin{array}{l}0.0007 \\
1.4192 \\
0.0092 \\
0.0059 \\
0.4314 \\
0.5389 \\
0.0213\end{array}$ & $\begin{array}{l}2.5212 \\
0.0000 \\
1.4742 \\
0.0046 \\
0.0094 \\
0.4798 \\
0.4858 \\
0.0190 \\
4.9941\end{array}$ & $\begin{array}{l}2.5668 \\
0.0024 \\
1.4240 \\
0.0092 \\
0.0080 \\
0.4344 \\
0.5296 \\
0.0183 \\
4.9928\end{array}$ & $\begin{array}{l}0 . \\
1 . \\
0 . \\
0 . \\
0 . \\
0 . \\
0 . \\
4 .\end{array}$ & $\begin{array}{l}1 \\
0 \\
0 \\
0 \\
0 \\
0\end{array}$ & $\begin{array}{l}7 \\
7 \\
15 \\
0 \\
8 \\
3 \\
7 \\
6\end{array}$ & $\begin{array}{l}4 \\
4 \\
4 \\
6 \\
0 \\
0 \\
3 \\
0\end{array}$ & $\begin{array}{l}2 \\
4 \\
4 \\
3 \\
9 \\
8 \\
9 \\
3\end{array}$ & $\begin{array}{l}15 \\
0 \\
0 \\
5 \\
5 \\
9 \\
2 \\
2 \\
0\end{array}$ & $\begin{array}{l}0 \\
4 \\
9 \\
1 \\
6 \\
3 \\
5 \\
2\end{array}$ & $\begin{array}{l}24 \\
27 \\
14 \\
30 \\
3 \\
8\end{array}$ & & & \\
\hline An & $\begin{array}{l}0.50 \\
0.47\end{array}$ & 27 & 74 & 18 & ק & 0 & & & & & & & & & & & & \\
\hline
\end{tabular}




\begin{tabular}{|c|c|c|c|c|c|c|c|c|c|c|c|c|c|c|c|c|c|c|}
\hline $\begin{array}{l}\text { Strat\# } \\
\text { field\# } \\
\text { Grain } \\
\text { Anal\# }\end{array}$ & $\begin{array}{r}\text { PF }-38 \\
85 \mathrm{cns} 38 \\
\text { pl3r } \\
124\end{array}$ & $\begin{array}{r}P F-38 \\
85 \mathrm{cns} 38 \\
p 14 \mathrm{c} \\
125\end{array}$ & $\begin{array}{r}\text { PF-38 } \\
85 \text { crs } 38 \\
\text { pl4r } \\
126\end{array}$ & $\begin{array}{r}\text { PF }-38 \\
85 \operatorname{cns} 38 \\
\text { PI5c } \\
127\end{array}$ & $\begin{array}{r}P F-38 \\
85 \mathrm{cns} 38 \\
p / 5 r \\
128\end{array}$ & $\begin{array}{r}\text { PF-38 } \\
85 \text { cns38 } \\
\text { Pl } 6 r \\
130\end{array}$ & $\begin{array}{r}\text { PF-38 } \\
85 \text { ens } 38 \\
\text { pl6sc } \\
129\end{array}$ & $\begin{array}{r}\text { PF }-38 \\
85 \mathrm{cns} 38 \\
\text { Pl7g } \\
131\end{array}$ & $\begin{array}{r}\text { PCP-A03 } \\
85 \mathrm{cns52} \\
\text { pl 1c } \\
60\end{array}$ & $\begin{array}{r}P C P-A 03 \\
85 e n s 52 \\
p l 1 r \\
62\end{array}$ & $\begin{array}{r}P C P-A 03 \\
85 \mathrm{cns52} \\
\text { pl } 1 \mathrm{sm} \\
61\end{array}$ & $\begin{array}{r}P C P-A 03 \\
85 e n s 52 \\
\text { pl2c } \\
63\end{array}$ & $\begin{array}{r}\text { PCP-A03 } \\
85 \text { cns52 } \\
\text { pl2r } \\
64\end{array}$ & $\begin{array}{r}\text { PCP-A03 } \\
85 \mathrm{cns} 52 \\
\text { pl3c } \\
65\end{array}$ & $\begin{array}{r}P C P-103 \\
85 e n s 52 \\
p 13 r \\
66\end{array}$ & $\begin{array}{r}P C P-A 03 \\
85 \mathrm{cns52} \\
\mathrm{Pl} / \mathrm{r} \\
68\end{array}$ & $\begin{array}{r}\text { PCP-A03 } \\
85 \mathrm{cns} 52 \\
\text { pl48c } \\
67\end{array}$ & $\begin{array}{r}P C P-A 03 \\
85 c n s 52 \\
P 15 c \\
69\end{array}$ \\
\hline $\begin{array}{l}\text { wtX oxide } \\
\text { sioz } \\
\text { Ti02 } \\
\text { Al } 203 \\
\text { FezO3 } \\
\text { FeO } \\
\text { CoO } \\
\text { No20 } \\
\text { K20 } \\
\text { tot } \\
\text { FeO meas. }\end{array}$ & $\begin{array}{r}51.45 \\
0.03 \\
30.51 \\
0.21 \\
0.19 \\
13.23 \\
3.82 \\
0.10 \\
99.54 \\
0.38\end{array}$ & $\begin{array}{r}48.78 \\
0.00 \\
32.39 \\
0.29 \\
0.12 \\
15.60 \\
2.52 \\
0.09 \\
99.79 \\
0.38\end{array}$ & $\begin{array}{r}51.92 \\
0.01 \\
29.90 \\
0.42 \\
0.19 \\
13.16 \\
3.71 \\
0.11 \\
99.41 \\
0.56\end{array}$ & $\begin{array}{r}51.68 \\
0.02 \\
30.79 \\
0.22 \\
0.32 \\
13.31 \\
3.80 \\
0.11 \\
100.25 \\
0.52\end{array}$ & $\begin{array}{r}53.20 \\
0.07 \\
30.13 \\
0.10 \\
0.32 \\
12.26 \\
4.35 \\
0.18 \\
100.61 \\
0.41\end{array}$ & $\begin{array}{r}53.13 \\
0.09 \\
29.67 \\
0.25 \\
0.28 \\
12.05 \\
4.43 \\
0.16 \\
100.07 \\
0.51\end{array}$ & $\begin{array}{r}49.44 \\
0.05 \\
32.13 \\
0.36 \\
0.14 \\
15.28 \\
2.68 \\
0.07 \\
100.16 \\
0.47\end{array}$ & $\begin{array}{r}54.23 \\
0.00 \\
29.12 \\
0.31 \\
0.23 \\
11.61 \\
4.81 \\
0.17 \\
100.48 \\
0.51\end{array}$ & $\begin{array}{r}52.12 \\
0.03 \\
30.20 \\
0.44 \\
0.01 \\
13.20 \\
3 . .97 \\
0.13 \\
100.10 \\
0.41\end{array}$ & $\begin{array}{r}52.49 \\
0.02 \\
29.91 \\
0.46 \\
0.17 \\
12.95 \\
3.97 \\
0.913 \\
100.10 \\
0.58\end{array}$ & $\begin{array}{r}50.20 \\
0.02 \\
31.60 \\
0.46 \\
0.07 \\
14.84 \\
3.00 \\
0.12 \\
100.31 \\
0.48\end{array}$ & $\begin{array}{r}52.36 \\
0.07 \\
29.58 \\
0.38 \\
0.00 \\
12.74 \\
4.10 \\
0.14 \\
99.37 \\
0.34\end{array}$ & $\begin{array}{r}52.38 \\
0.08 \\
29.65 \\
0.51 \\
0.11 \\
12.72 \\
4.05 \\
0.15 \\
99.65 \\
0.57\end{array}$ & $\begin{array}{r}47.56 \\
0.04 \\
33.10 \\
0.12 \\
0.12 \\
16.23 \\
2.07 \\
0.07 \\
99.31 \\
0.23\end{array}$ & $\begin{array}{r}52 . \\
0 . \\
29 . \\
0 . \\
0 . \\
13 . \\
4 . \\
0 . \\
100 . \\
0 .\end{array}$ & $\begin{array}{r}52.35 \\
0.05 \\
29.55 \\
0.48 \\
0.12 \\
12.63 \\
4.11 \\
0.13 \\
99.42 \\
0.55\end{array}$ & $\begin{array}{r}47.30 \\
0.00 \\
33.38 \\
0.36 \\
0.10 \\
16.89 \\
1.79 \\
0.05 \\
99.88 \\
0.43\end{array}$ & $\begin{array}{r}51.44 \\
0.03 \\
29.93 \\
0.46 \\
0.12 \\
12.89 \\
4.08 \\
0.12 \\
9.08\end{array}$ \\
\hline $\begin{array}{l}\text { atoms } / 8 \\
\text { Si } \\
\text { Ti } \\
\text { Al } \\
\text { Fe3+ } \\
\text { Fe2+ } \\
\text { Ce } \\
\text { Ma } \\
\text { K } \\
\text { tot }\end{array}$ & $\begin{array}{l}2.3499 \\
0.0010 \\
1.6428 \\
0.0073 \\
0.0072 \\
0.6475 \\
0.3383 \\
0.0058 \\
4.9998\end{array}$ & $\begin{array}{l}2.2380 \\
0.0000 \\
1.7519 \\
0.0101 \\
0.0045 \\
0.7669 \\
0.2242 \\
0.0053 \\
5.0008\end{array}$ & $\begin{array}{l}2.3739 \\
0.0003 \\
1.6117 \\
0.0143 \\
0.0071 \\
0.6447 \\
0.3289 \\
0.0064 \\
4.9875\end{array}$ & $\begin{array}{l}2.3452 \\
0.0007 \\
1.6473 \\
0.0075 \\
0.0122 \\
0.6472 \\
0.3344 \\
0.0064 \\
5.0008\end{array}$ & $\begin{array}{l}2.3964 \\
0.0024 \\
1.6001 \\
0.0035 \\
0.0119 \\
0.5917 \\
0.3799 \\
0.0103\end{array}$ & $\begin{array}{l}2.4068 \\
0.0031 \\
1.5846 \\
0.0086 \\
0.0107 \\
0.5849 \\
0.3891 \\
0.0092 \\
4.9970\end{array}$ & $\begin{array}{l}2.2578 \\
0.0017 \\
1.7298 \\
0.0124 \\
0.0055 \\
0.7477 \\
0.2375 \\
0.0041 \\
4.9963\end{array}$ & $\begin{array}{l}2.4429 \\
0.0000 \\
1.5465 \\
0.0107 \\
0.0086 \\
0.5604 \\
0.4201 \\
0.0098 \\
4.9988\end{array}$ & $\begin{array}{l}2.3676 \\
0.0010 \\
1.6173 \\
0.0150 \\
0.0005 \\
0.6425 \\
0.3497 \\
0.0073 \\
5.0013\end{array}$ & $\begin{array}{l}2.3833 \\
0.0007 \\
1.6010 \\
0.0157 \\
0.0063 \\
0.6300 \\
0.3495 \\
0.0075 \\
4.9941\end{array}$ & $\begin{array}{l}0.0 \\
1.6 \\
0.0 \\
0.0 \\
0.7 \\
0.2 \\
0.0 \\
4.9\end{array}$ & $\begin{array}{l}2.3 \\
0.0 \\
1.5 \\
0.0 \\
0.0 \\
0.6 \\
0.3 \\
0.0 \\
4.9\end{array}$ & $\begin{array}{l}0.0 \\
1.5 \\
0.0 \\
0.0 \\
0.6 \\
0.3 \\
0.0\end{array}$ & $\begin{array}{l}2.1 \\
0.0 \\
1.8 \\
0.0 \\
0.0 \\
0.8 \\
0.8 \\
0.0 \\
4.8\end{array}$ & $\begin{array}{l}0.0 \\
1.0 \\
0.0 \\
0.0 \\
0.0 \\
0.3 \\
0.0\end{array}$ & $\begin{array}{l}9 \\
7 \\
4 \\
6 \\
6 \\
3 \\
1 \\
6 \\
4\end{array}$ & & $\begin{array}{l}0 \\
0 . \\
0 . \\
0 \\
5\end{array}$ \\
\hline${ }_{A b}^{A n}$ & $\begin{array}{l}0.65 \\
0.34 \\
0.00\end{array}$ & $\begin{array}{l}0.76 \\
0.22 \\
0.00\end{array}$ & $\begin{array}{l}0.65 \\
0.33\end{array}$ & $\begin{array}{l}0.65 \\
0.33 \\
0.00\end{array}$ & $\begin{array}{l}0.60 \\
0.38\end{array}$ & $\begin{array}{l}0.59 \\
0.39 \\
0.00\end{array}$ & 0.2 & $\begin{array}{l}0.4 \\
0.0\end{array}$ & $\begin{array}{l}0.3 \\
0.0\end{array}$ & $\begin{array}{l}0.3 \\
0.0\end{array}$ & $\begin{array}{r}70 \\
60 \\
70\end{array}$ & 0.3 & $\begin{array}{l}88 \\
33 \\
88\end{array}$ & $\begin{array}{l}0 \\
0 .\end{array}$ & $\frac{4}{5}$ & 0. & & \\
\hline
\end{tabular}




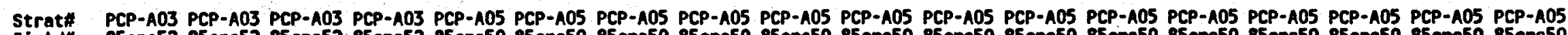
Field\# 85cns52 85ens52 85ens52 85ens52 85ens50 85ens50 85 ens50 85ens50 85 ens50 85 ens50 85 ens50 85 cns50 85 cns50 85 cns50 85 ens50 85 cns50 85 ens50 85 ens50

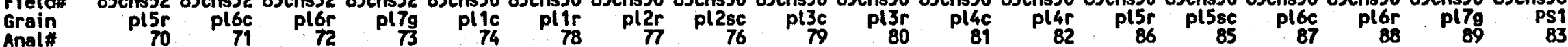

WtX oxide

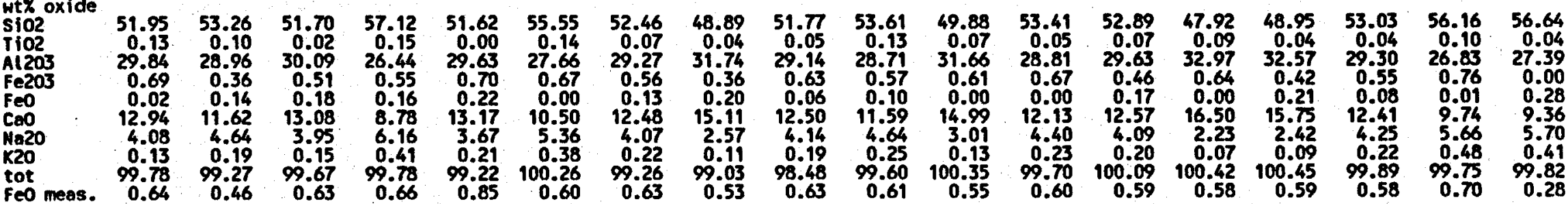

feo meas.

atoms $/ 80$$$
\text { si }
$$$$
\text { ii } 2.3707
$$

$\begin{array}{llllllllll}2.3707 & 2.4300 & 2.3620 & 2.5756 & 2.3713 & 2.5048 & 2.4013 & 2.2587 & 2.3912 \\ 0.0045 & 0.0034 & 0.0007 & 0.0051 & 0.0000 & 0.0047 & 0.0024 & 0.0014 & 0.00\end{array}$

0.60

0.55

.59

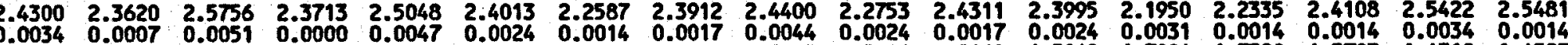
$\begin{array}{llllllllllllllllllll} & & 0 & 1.5578 & 1.6207 & 1.4056 & 1.6047 & 1.4704 & 1.5795 & 1.7287 & 1.5868 & 1.5405 & 1.7026 & 1.5460 & 1.5848 & 1.7804 & 1.7520 & 1.5703 & 1.4318 & 1.4527\end{array}$

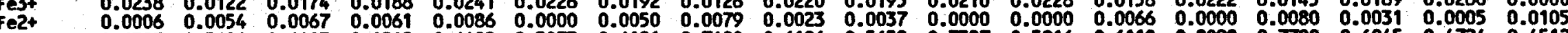

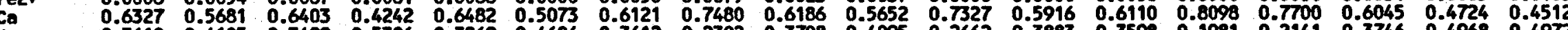
$\begin{array}{llllllllllllllllllllllll}\text { Ma } & 0.3610 & 0.4105 & 0.3499 & 0.5386 & 0.3269 & 0.4686 & 0.3612 & 0.2302 & 0.3708 & 0.4095 & 0.2662 & 0.3883 & 0.3598 & 0.1981 & 0.2141 & 0.3746 & 0.4968 & 0.4972\end{array}$ $\begin{array}{llllllllllllllllllllllll}K & 0.0076 & 0.0111 & 0.0087 & 0.0236 & 0.0123 & 0.0219 & 0.0128 & 0.0065 & 0.0112 & 0.0145 & 0.0076 & 0.0134 & 0.0116 & 0.0041 & 0.0052 & 0.0128 & 0.0277 & 0.0235\end{array}$

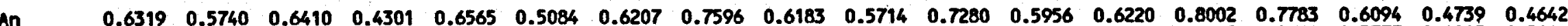

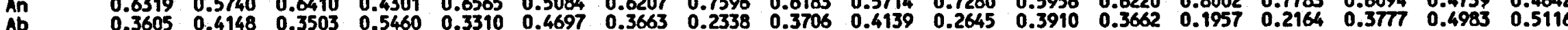

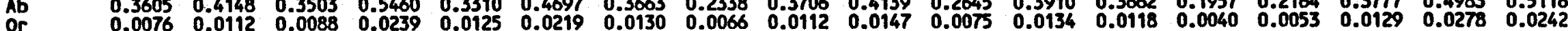




\begin{tabular}{|c|c|c|c|c|c|c|c|c|c|c|c|c|c|c|c|c|c|c|}
\hline $\begin{array}{l}\text { Strat\# } \\
\text { field\# } \\
\text { Grain }\end{array}$ & $\begin{array}{r}\text { PCP-A05 } \\
85 \text { cns50 } \\
\text { PS1 } \\
84\end{array}$ & $\begin{array}{r}\text { PCP-A05 } \\
85 \text { ens50 } \\
\text { PS2 } \\
1\end{array}$ & $\begin{array}{r}\text { PCP-A05 } \\
85 \mathrm{ens50} \\
\text { PS2 } \\
2\end{array}$ & $\begin{array}{r}c p-07 \\
85 \text { ens60 } \\
\text { pl 1c } \\
90\end{array}$ & $\begin{array}{r}\text { cp-07 } \\
85 \mathrm{cns} 60 \\
\mathrm{pl} \mathrm{ir} \\
91\end{array}$ & $\begin{array}{r}\mathrm{cP}-07 \\
85 \mathrm{cns} 60 \\
\text { pl2r1 } \\
93\end{array}$ & $\begin{array}{r}c p-07 \\
85 \mathrm{cns} 60 \\
p 12 r 2 \\
97\end{array}$ & $\begin{array}{r}c P-07 \\
85 \mathrm{cns} 60 \\
p 12 s c \\
94\end{array}$ & $\begin{array}{r}\text { cP-07 } \\
85 \mathrm{cns} 60 \\
\mathrm{pl} 3 \mathrm{r} \\
96\end{array}$ & $\begin{array}{r}\mathrm{cP}-07 \\
85 \mathrm{cns} 60 \\
\mathrm{pl} 3 \mathrm{sc} \\
95\end{array}$ & $\begin{array}{r}\text { CP-07 } \\
85 \text { ens60 } \\
\text { pl } 4 \mathrm{c} \\
98\end{array}$ & $\begin{array}{r}\text { cp-07 } \\
85 \text { cns60 } \\
\text { pl } 4 r \\
99\end{array}$ & $\begin{array}{r}\text { cP-07 } \\
85 \mathrm{cns60} \\
p 15 r \\
101\end{array}$ & $\begin{array}{r}\text { cP-07 } \\
85 \text { cns60 } \\
\text { pl5sc } \\
100\end{array}$ & $\begin{array}{r}\text { cP-07 } \\
85 \mathrm{cns} 60 \\
\text { pl6c } \\
102\end{array}$ & $\begin{array}{r}\text { cP-07 } \\
85 \mathrm{cns} 60 \\
p 17 g \\
103\end{array}$ & $\begin{array}{r}\mathrm{CP} \\
85 \mathrm{cn} \\
p\end{array}$ & $\begin{array}{r}\text { CP-12 } \\
85 \mathrm{cns20} \\
\text { pl 1r } \\
105\end{array}$ \\
\hline $\begin{array}{l}\text { wtX oxide } \\
\text { sio2 } \\
\text { Ti02 } \\
\text { Alzo3 } \\
\text { fezo3 } \\
\text { FeO } \\
\text { CaO } \\
\text { Ma20 } \\
\text { K20 } \\
\text { tot } \\
\text { FeO meas. }\end{array}$ & $\begin{array}{r}55.36 \\
0.07 \\
29.03 \\
0.09 \\
0.10 \\
11.10 \\
5.07 \\
0.29 \\
101.11 \\
0.18\end{array}$ & $\begin{array}{r}57.23 \\
0.04 \\
25.18 \\
0.26 \\
0.00 \\
8.57 \\
6.10 \\
97.41 \\
97.41 \\
0.23\end{array}$ & $\begin{array}{r}54.71 \\
0.04 \\
28.05 \\
0.34 \\
0.00 \\
11.14 \\
4.95 \\
99.31 \\
0.31\end{array}$ & $\begin{array}{r}49.21 \\
0.02 \\
32.55 \\
0.35 \\
0.13 \\
15.56 \\
2.67 \\
0.08 \\
100.56 \\
0.44\end{array}$ & $\begin{array}{r}48.83 \\
0.07 \\
32.51 \\
0.48 \\
0.16 \\
15.64 \\
2.59 \\
0.06 \\
100.32 \\
0.57\end{array}$ & $\begin{array}{r}47.87 \\
0.07 \\
33.15 \\
0.48 \\
0.00 \\
16.58 \\
2.07 \\
0.05 \\
100.27 \\
0.43\end{array}$ & $\begin{array}{r}47.98 \\
0.00 \\
33.29 \\
0.16 \\
0.33 \\
16.23 \\
2.10 \\
0.04 \\
100.11 \\
0.46\end{array}$ & $\begin{array}{r}49.48 \\
0.00 \\
32.32 \\
0.40 \\
0.16 \\
15.43 \\
2.68 \\
0.14 \\
100.61 \\
0.52\end{array}$ & $\begin{array}{r}51.47 \\
0.05 \\
30.46 \\
0.58 \\
0.15 \\
13.58 \\
3.69 \\
0.09 \\
100.07 \\
0.67\end{array}$ & $\begin{array}{r}50.20 \\
0.01 \\
31.73 \\
0.23 \\
0.26 \\
14.64 \\
2.96 \\
0.14 \\
100.17 \\
0.47\end{array}$ & $\begin{array}{r}48.83 \\
0.08 \\
32.80 \\
0.25 \\
0.13 \\
15.74 \\
2.43 \\
0.11 \\
100.38 \\
0.36\end{array}$ & $\begin{array}{r}54.81 \\
0.08 \\
28.63 \\
0.11 \\
0.20 \\
10.72 \\
5.18 \\
0.25 \\
99.98 \\
0.30\end{array}$ & $\begin{array}{r}51.67 \\
0.07 \\
30.41 \\
0.43 \\
0.25 \\
13.18 \\
3.86 \\
0.11 \\
100.18 \\
0.64\end{array}$ & $\begin{array}{r}48 . \\
0 . \\
33 . \\
0 . \\
0 . \\
16 . \\
2 . \\
0 . \\
100 . \\
0 .\end{array}$ & $\begin{array}{r}53.96 \\
0.07 \\
29.04 \\
0.74 \\
0.02 \\
11.87 \\
4.82 \\
0.25 \\
100.76 \\
0.68\end{array}$ & $\begin{array}{r}56.26 \\
0.13 \\
27.21 \\
0.68 \\
0.33 \\
9.63 \\
5.73 \\
0.33 \\
100.30 \\
0.94\end{array}$ & $\begin{array}{r}47.36 \\
0.00 \\
33.91 \\
0.15 \\
0.26 \\
17.00 \\
1.71 \\
0.02 \\
100.40 \\
0.39\end{array}$ & $\begin{array}{r}0.04 \\
29.58 \\
0.41 \\
0.12 \\
12.44 \\
4.30 \\
0.14 \\
99.94\end{array}$ \\
\hline $\begin{array}{l}\text { Si } \\
\text { Ti } \\
\text { Al } \\
\text { fez+ } \\
\text { fe2+ } \\
\text { Ca } \\
\mathrm{Na} \\
\mathrm{K} \\
\text { tot }\end{array}$ & $\begin{array}{l}2.4700 \\
0.0023 \\
1.5270 \\
0.0031 \\
0.0036 \\
0.5307 \\
0.4386 \\
0.0165 \\
4.9918\end{array}$ & $\begin{array}{l}0.0014 \\
1.3620 \\
0.0088 \\
0.0000 \\
0.4213 \\
0.5427 \\
4.9632\end{array}$ & $\begin{array}{r}0.0014 \\
1.5017 \\
0.0118 \\
0.0000 \\
0.5420 \\
0.4359 \\
\text { nd }\end{array}$ & $\begin{array}{l}2.2407 \\
0.0007 \\
1.7473 \\
0.0119 \\
0.0048 \\
0.7592 \\
0.2357 \\
0.0046 \\
5.0051\end{array}$ & $\begin{array}{l}2.2317 \\
0.0024 \\
1.7517 \\
0.0166 \\
0.0052 \\
0.7659 \\
0.2295 \\
0.0035 \\
5.0065\end{array}$ & $\begin{array}{l}2.1930 \\
0.0024 \\
1.7904 \\
0.0165 \\
0.0000 \\
0.8139 \\
0.1839 \\
0.0029 \\
5.0028\end{array}$ & $\begin{array}{l}2.1976 \\
0.0000 \\
1.7976 \\
0.0049 \\
0.0127 \\
0.7965 \\
0.1865 \\
0.0023 \\
4.9981\end{array}$ & $\begin{array}{l}2.2 \\
0.0 \\
1.7 \\
0.0 \\
0.0 \\
0.7 \\
0.2 \\
0.0 \\
5.0\end{array}$ & $\begin{array}{l}2.3445 \\
0.0017 \\
1.6357 \\
0.0197 \\
0.0058 \\
0.6628 \\
0.3259 \\
0.0052 \\
5.0015\end{array}$ & $\begin{array}{l}0.6 \\
0.0 \\
1.7 \\
0.0 \\
0.0 \\
0.7 \\
0.2 \\
0.0 \\
4.9\end{array}$ & $\begin{array}{l}0.0 \\
1.7 \\
0.0 \\
0.0 \\
0.7 \\
0.2 \\
0.0 \\
4.9\end{array}$ & $\begin{array}{l}2.4 \\
0.0 \\
1.5 \\
0.0 \\
0.0 \\
0.5 \\
0.4 \\
0.0 \\
4.9\end{array}$ & $\begin{array}{l}1.8 \\
0.0 \\
0.0 \\
0.0 \\
0.9 \\
0.8\end{array}$ & $\begin{array}{l}4 \\
0 \\
5 \\
0 \\
9 \\
1 \\
5 \\
1 \\
6\end{array}$ & $\begin{array}{l}0 \\
4 \\
0 \\
0 \\
7 \\
2 \\
2 \\
2 \\
4\end{array}$ & $\begin{array}{l}0 . \\
1 . \\
0 . \\
0 . \\
0 . \\
0 .\end{array}$ & & \\
\hline $\begin{array}{l}A n \\
A b \\
O r\end{array}$ & $\begin{array}{l}0.53 \\
0.4\end{array}$ & $\begin{array}{l}0 . \\
0 . \\
0 .\end{array}$ & 0 & 0 & 0.2 & $\begin{array}{l}0.8 \\
0.1 \\
0.0\end{array}$ & 4 & $\begin{array}{l}7 \\
2 \\
2\end{array}$ & 5 & $\begin{array}{l}7 \\
3\end{array}$ & & & & $\begin{array}{l}7 \\
2 \\
1\end{array}$ & & & & \\
\hline
\end{tabular}




\begin{tabular}{|c|c|c|c|c|c|c|c|c|c|c|c|c|c|c|c|c|c|c|}
\hline $\begin{array}{l}\text { Strat\# } \\
\text { Fieto\# } \\
\text { Grain } \\
\text { Anal\# }\end{array}$ & $\begin{array}{r}c P-12 \\
85 \mathrm{cns} 20 \\
p ! 2 r \\
107\end{array}$ & $\begin{array}{r}c P-12 \\
85 \mathrm{cns} 20 \\
p 13 \mathrm{c} \\
108\end{array}$ & $\begin{array}{r}\text { cp-12 } \\
85 \mathrm{cns} 20 \\
p 13 r \\
109\end{array}$ & $\begin{array}{r}c P-12 \\
85 \mathrm{cns} 20 \\
\text { pl } 4 \mathrm{C} \\
110\end{array}$ & $\begin{array}{r}c p-12 \\
85 \mathrm{cns} 20 \\
p l 4 r \\
111\end{array}$ & $\begin{array}{r}c p-12 \\
85 \mathrm{cns} 20 \\
p / 5 c \\
113\end{array}$ & $\begin{array}{r}\mathrm{cP}-12 \\
85 \mathrm{cns} 20 \\
\mathrm{pl} / \mathrm{r} \\
114\end{array}$ & $\begin{array}{r}c P-12 \\
85 \mathrm{cns} 20 \\
p l 6 c \\
115\end{array}$ & $\begin{array}{r}c P-12 \\
85 \mathrm{cns} 20 \\
p 16 r \\
117\end{array}$ & $\begin{array}{r}c P-12 \\
85 \mathrm{cns} 20 \\
\text { pl6sr } \\
116\end{array}$ & $\begin{array}{r}c p-12 \\
85 \mathrm{cns} 20 \\
p 17 g \\
118\end{array}$ & $\begin{array}{r}\text { Pun- } 17 \\
85 \mathrm{cns} 17 \\
\text { pl } 10 \mathrm{~g} \\
198\end{array}$ & $\begin{array}{r}\text { Pum- } \\
85 \mathrm{cns} \\
\text { p! }\end{array}$ & $\begin{array}{r}\text { PUA-17 } \\
85 \mathrm{cns} 17 \\
\text { pl1r } \\
181\end{array}$ & $\begin{array}{l}\text { PUin- } \\
\text { 85cne } \\
\text { Pl }\end{array}$ & $\begin{array}{l}17 \\
17 \\
3 c \\
32\end{array}$ & & \\
\hline $\begin{array}{l}\text { wt\% oxide } \\
\text { sio2 } \\
\text { TiO2 } \\
\text { Alzo3 } \\
\text { Fezo3 } \\
\text { FeO } \\
\text { CaO } \\
\text { Na20 } \\
\text { K20 } \\
\text { tot } \\
\text { FeO meas. }\end{array}$ & $\begin{array}{r}51.98 \\
0.03 \\
30.29 \\
0.42 \\
0.12 \\
13.27 \\
3.85 \\
0.11 \\
100.07 \\
0.50\end{array}$ & $\begin{array}{r}48.30 \\
0.00 \\
33.40 \\
0.00 \\
0.33 \\
16.03 \\
2.26 \\
0.07 \\
100.39 \\
0.33\end{array}$ & $\begin{array}{r}53.76 \\
0.08 \\
29.69 \\
0.46 \\
0.28 \\
12.25 \\
4.41 \\
0.14 \\
101.08 \\
0.70\end{array}$ & $\begin{array}{r}46.98 \\
0.04 \\
33.82 \\
0.26 \\
0.23 \\
16.86 \\
1.84 \\
0.04 \\
100.07 \\
0.46\end{array}$ & $\begin{array}{r}51.90 \\
0.00 \\
30.78 \\
0.28 \\
0.32 \\
13.40 \\
3.76 \\
0.13 \\
100.58 \\
0.58\end{array}$ & $\begin{array}{r}46.84 \\
0.03 \\
34.73 \\
0.10 \\
0.29 \\
17.45 \\
1.59 \\
0.03 \\
101.08 \\
0.38\end{array}$ & $\begin{array}{r}52.26 \\
0.00 \\
30.28 \\
0.36 \\
0.30 \\
13.00 \\
3.99 \\
0.11 \\
100.31 \\
0.63\end{array}$ & $\begin{array}{r}46.52 \\
0.08 \\
34.43 \\
0.35 \\
0.08 \\
17.68 \\
1.45 \\
0.03 \\
100.63 \\
0.40\end{array}$ & $\begin{array}{r}48.39 \\
0.00 \\
33.25 \\
0.33 \\
0.18 \\
16.36 \\
2.21 \\
0.04 \\
100.76 \\
0.48\end{array}$ & $\begin{array}{r}47.93 \\
0.19 \\
33.44 \\
0.45 \\
0.10 \\
16.54 \\
2.11 \\
0.05 \\
100.74 \\
0.51\end{array}$ & $\begin{array}{r}52.36 \\
0.07 \\
30.21 \\
0.49 \\
0.18 \\
13.09 \\
3.96 \\
0.09 \\
100.45 \\
0.62\end{array}$ & $\begin{array}{r}51.86 \\
0.00 \\
30.47 \\
0.46 \\
0.20 \\
13.41 \\
3.82 \\
0.10 \\
100.32 \\
0.61\end{array}$ & $\begin{array}{r}52.64 \\
0.05 \\
29.60 \\
0.24 \\
0.22 \\
12.39 \\
4.16 \\
0.10 \\
99.40 \\
0.44\end{array}$ & $\begin{array}{r}51.43 \\
0.03 \\
30.55 \\
0.53 \\
0.13 \\
13.66 \\
3.66 \\
0.10 \\
100.09 \\
0.61\end{array}$ & $\begin{array}{r}52.08 \\
0.07 \\
30.26 \\
0.40 \\
0.25 \\
12.94 \\
4.01 \\
0.11 \\
100.12\end{array}$ & $\begin{array}{r}48.95 \\
0.04 \\
32.40 \\
0.40 \\
0.19 \\
15.54 \\
2.58 \\
0.05 \\
100.15 \\
0.55\end{array}$ & $\begin{array}{r}52.00 \\
0.02 \\
30.36 \\
0.35 \\
0.21 \\
13.18 \\
3.87 \\
0.12 \\
100.12 \\
0.53\end{array}$ & $\begin{array}{r}48 . \\
0 . \\
33 . \\
0 . \\
0 . \\
16 . \\
2 . \\
0 . \\
100 . \\
0 .\end{array}$ \\
\hline $\begin{array}{l}\text { Si } \\
\text { ji } \\
\text { Al } \\
\text { fej+ } \\
\text { fe2t } \\
\mathrm{Ca} \\
\mathrm{Na} \\
\mathrm{K}\end{array}$ & $\begin{array}{l}2.3626 \\
0.0010 \\
1.6231 \\
0.0143 \\
0.0047 \\
0.6463 \\
0.3393 \\
0.0064 \\
4.9977\end{array}$ & $\begin{array}{l}2.2036 \\
0.0000 \\
1.7964 \\
0.0000 \\
0.0126 \\
0.7836 \\
0.1999 \\
0.0041 \\
5.0002\end{array}$ & $\begin{array}{l}2.4132 \\
0.0027 \\
1.5712 \\
0.0156 \\
0.0107 \\
0.5892 \\
0.3838 \\
0.0080\end{array}$ & $\begin{array}{l}2.1589 \\
0.0014 \\
1.8323 \\
0.0088 \\
0.0089 \\
0.8302 \\
0.1640 \\
0.0023 \\
5.0067\end{array}$ & $\begin{array}{l}2.3484 \\
0.0000 \\
1.6419 \\
0.0097 \\
0.0123 \\
0.6497 \\
0.3299 \\
0.0075 \\
4.9993\end{array}$ & $\begin{array}{l}1.86 \\
0.00 \\
0.01 \\
0.85 \\
0.14 \\
0.00 \\
5.00\end{array}$ & $\begin{array}{l}2.3692 \\
0.0000 \\
1.6184 \\
0.0124 \\
0.0115 \\
0.6315 \\
0.3507 \\
0.0064 \\
5.0001\end{array}$ & $\begin{array}{l}7 \\
8 \\
2 \\
12 \\
12 \\
3 \\
37 \\
18 \\
37\end{array}$ & $\begin{array}{l}0.0 \\
1.7 \\
0.0 \\
0.00 \\
0.7 \\
0.1 \\
0.0 \\
5.0\end{array}$ & $\begin{array}{l}0.0 \\
1.7 \\
0.0 \\
0.0 \\
0.8 \\
0.1 \\
0.0 \\
5.0\end{array}$ & $\begin{array}{l}2.3707 \\
0.0024 \\
1.6126 \\
0.0167 \\
0.0068 \\
0.6351 \\
0.3477 \\
0.0052\end{array}$ & $\begin{array}{l}0.0 \\
1.8 \\
0.0 \\
0.0 \\
0.8 \\
0.3 \\
0.0 \\
5.8\end{array}$ & $\begin{array}{l}\frac{1}{7} \\
3 \\
4 \\
14 \\
4 \\
8 \\
8 \\
8\end{array}$ & $\begin{array}{l}0 . \\
1 . \\
0 . \\
0 . \\
0 . \\
0 . \\
0 . \\
5 .\end{array}$ & $\begin{array}{l}4 \\
5 \\
5 \\
8 \\
2 \\
2\end{array}$ & & & \\
\hline $\begin{array}{l}\text { Ab } \\
\text { or }\end{array}$ & $\begin{array}{l}0 \\
0 \\
0\end{array}$ & 0 & 12 & 0 & D & 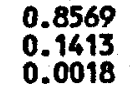 & 0 & $\begin{array}{l}22 \\
20 \\
18\end{array}$ & & & & & & & & & & \\
\hline
\end{tabular}




\begin{tabular}{|c|c|c|c|c|c|c|c|c|c|c|c|c|c|c|c|c|}
\hline & $F$ & $\mathbf{P}_{18}^{14}$ & 8 & $p$ & 8 & 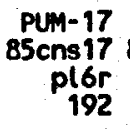 & & & & & & & $\min$ & & & dev \\
\hline $\begin{array}{l}102 \\
1203 \\
e 203 \\
e 0 \\
00 \\
020 \\
20 \\
0 t \\
00 \text { meas. }\end{array}$ & $\begin{array}{r}49.63 \\
0.00 \\
31.62 \\
0.30 \\
0.20 \\
14.64 \\
3.07 \\
0.06 \\
99.52 \\
0.47\end{array}$ & $\begin{array}{r}0.10 \\
30.34 \\
0.62 \\
0.07 \\
13.40 \\
3.84 \\
0.09 \\
99.82 \\
0.63\end{array}$ & $\begin{array}{r}50.95 \\
0.07 \\
30.84 \\
0.40 \\
0.23 \\
13.71 \\
3.55 \\
0.09 \\
99.84 \\
0.59\end{array}$ & $\begin{array}{r}46.01 \\
0.00 \\
34.16 \\
0.24 \\
0.29 \\
17.41 \\
1.46 \\
0.01 \\
99.57 \\
0.50\end{array}$ & $\begin{array}{r}46.01 \\
0.04 \\
34.29 \\
0.25 \\
0.33 \\
17.53 \\
1.31 \\
0.02 \\
99.79 \\
0.56\end{array}$ & $\begin{array}{r}46.46 \\
0.03 \\
34.23 \\
0.37 \\
0.23 \\
17.49 \\
1.50 \\
0.03 \\
100.34 \\
0.56\end{array}$ & $\begin{array}{r}46.45^{\circ} \\
0.04 \\
33.87 \\
0.35 \\
0.27 \\
17.17 \\
1.57 \\
0.04 \\
99.75 \\
0.58\end{array}$ & $\begin{array}{r}46.83 \\
0.07 \\
32.76 \\
0.56 \\
0.12 \\
16.27 \\
2.13 \\
0.04 \\
98.79 \\
0.63\end{array}$ & $\begin{array}{r}0.03 \\
29.84 \\
0.24 \\
0.28 \\
12.62 \\
4.03 \\
0.10\end{array}$ & $\begin{array}{r}50.71 \\
0.00 \\
31.08 \\
0.36 \\
0.17 \\
14.10 \\
3.39 \\
0.08 \\
99.89 \\
0.49\end{array}$ & $\begin{array}{l}1.54 \\
0.07 \\
0.05 \\
0.33 \\
0.30 \\
2.82 \\
3.93 \\
0.99 \\
0.13 \\
0.60\end{array}$ & $\begin{array}{r}51.71 \\
0.07 \\
30.84 \\
0.53 \\
0.26 \\
13.03 \\
3.71 \\
0.08 \\
100.83\end{array}$ & $\begin{array}{l}0 . \\
6 . \\
1 . \\
0 .\end{array}$ & $\begin{array}{r}0.41 \\
0.16 \\
34.73 \\
0.90 \\
0.47 \\
18.23 \\
6.88 \\
00.82 \\
101.17 \\
1.02\end{array}$ & & \\
\hline $2+$ & $\begin{array}{l}0.0000 \\
1.7113 \\
0.0105 \\
0.0076 \\
0.7201 \\
0.2733 \\
0.0035\end{array}$ & $\begin{array}{l}2.3454 \\
0.0034 \\
1.6334 \\
0.0213 \\
0.0028 \\
0.6557 \\
0.3400 \\
0.0052 \\
5.0071\end{array}$ & $\begin{array}{l}0.0024 \\
1.6599 \\
0.0139 \\
0.0086 \\
0.6707 \\
0.3143 \\
0.0052\end{array}$ & $\begin{array}{l}0.0 \\
1.8 \\
0.0 \\
0.0 \\
0.8 \\
0.1 \\
0.0 \\
5.0\end{array}$ & $\begin{array}{l}0.0014 \\
1.8667 \\
0.0088 \\
0.0128 \\
0.8673 \\
0.1173 \\
0.0012 \\
5.0000\end{array}$ & $\begin{array}{l}0.0 \\
1.8 \\
0.0 \\
0.0 \\
0.8 \\
0.1 \\
0.0 \\
5.0\end{array}$ & & & & & & & & & & \\
\hline & & & & & & & & & & & & & & & & \\
\hline
\end{tabular}




\section{APPENDIX IV - Olivine compositions}

Olivine compositons were determined on the JEOL JXA-733 microprobe at Southern Methodist University using standard analytical stratagies and instrumental settings. No attempt was specifically made to optimize the instrumental settings for the determination of minor elements. 
Spurr Volcanic Complex olivine analyses

Strat\# AMS-AO4 AMS-A04 AMS-A04 AMS-A04 AMS-A04 AMS-A04 AMS-A04 AMS-A04 AMS-A04 AMS-A04 AMS-B07 AMS-B07 AMS-B07 AMS-B07 AMS-B07 AMS-B07 AMS-B07 AMS-B07

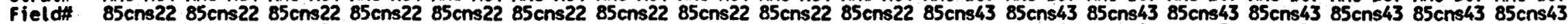

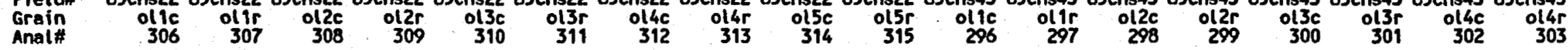

$\begin{array}{lllllllllllllllllllllll}\text { Ht\% } & 37.15 & 36.88 & 37.60 & 36.15 & 37.33 & 36.88 & 37.06 & 36.47 & 38.42 & 36.87 & 37.93 & 37.13 & 37.27 & 36.32 & 38.13 & 37.40 & 38.44 & 37.41\end{array}$

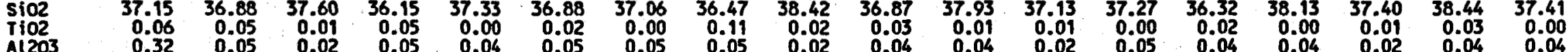

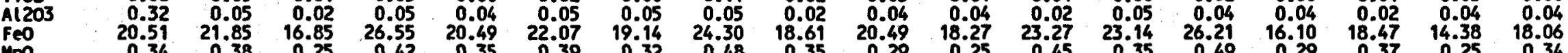

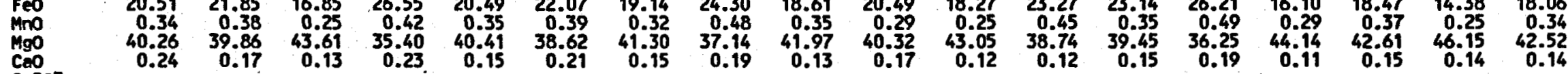

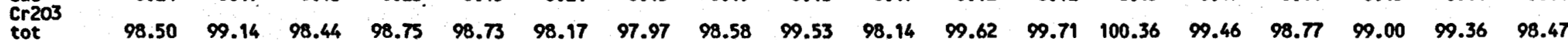
(1)

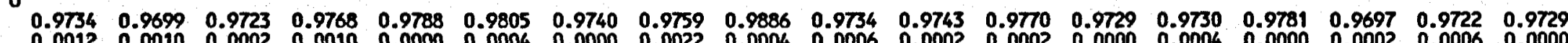

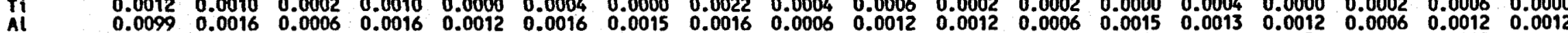
$\begin{array}{lllllllllllllllllllll}\text { fe2+ } & 0.4495 & 0.4806 & 0.3644 & 0.6000 & 0.4493 & 0.4907 & 0.4207 & 0.5438 & 0.4005 & 0.4524 & 0.3925 & 0.5121 & 0.5052 & 0.5873 & 0.3454 & 0.4005 & 0.3042 & 0.3928\end{array}$

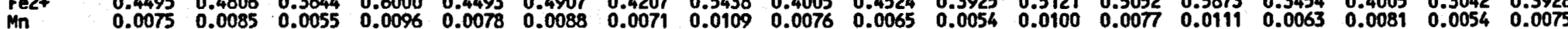
$\begin{array}{lllllllllllllllllll}M n & 0.00722 & 1.5622 & 1.6806 & 1.4256 & 1.5791 & 1.5303 & 1.6176 & 1.4812 & 1.6095 & 1.5864 & 1.6480 & 1.5192 & 1.5348 & 1.4474 & 1.6874 & 1.6465 & 1.7394 & 1.6481\end{array}$ $\begin{array}{lllllllllllllllllllllllll}\text { Ca } & 0.0067 & 0.0048 & 0.0036 & 0.0067 & 0.0042 & 0.0060 & 0.0042 & 0.0054 & 0.0036 & 0.0048 & 0.0033 & 0.0034 & 0.0042 & 0.0055 & 0.0030 & 0.0042 & 0.0038 & 0.0039\end{array}$

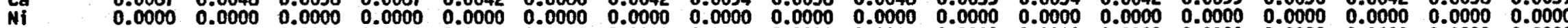

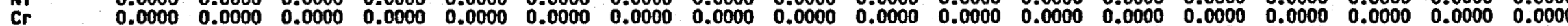

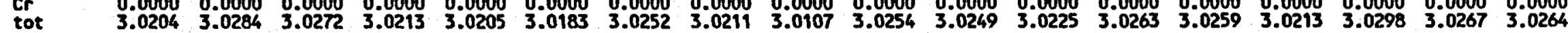

$\begin{array}{llllllllllllllllllllllllllllllll}\text { Fa } & 0.2223 & 0.2352 & 0.1782 & 0.2962 & 0.2215 & 0.2428 & 0.2064 & 0.2686 & 0.1992 & 0.2219 & 0.1923 & 0.2521 & 0.2476 & 0.2886 & 0.1699 & 0.1957 & 0.1488 & 0.1925\end{array}$

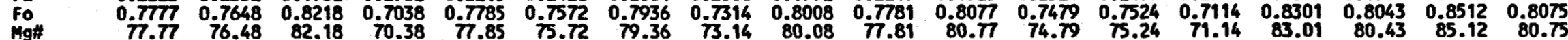




\begin{tabular}{|c|c|c|c|c|c|c|c|c|c|c|c|c|c|c|c|c|c|c|}
\hline $\begin{array}{l}\text { Strat\# } \\
\text { Field\# } \\
\text { Grain } \\
\text { Anol\# }\end{array}$ & $\begin{array}{r}\text { AMs-B07 } \\
85 \mathrm{cns} 43 \\
015 \mathrm{c} \\
304\end{array}$ & $\begin{array}{r}\text { AMs-B07 } \\
85 \text { cns } 43 \\
\text { ot } 5 r \\
305\end{array}$ & $\begin{array}{r}\text { AMs-807 } \\
85 \mathrm{cns} 43 \\
\text { ol } 6 \mathrm{C} \\
26\end{array}$ & $\begin{array}{r}\text { AMS-807 } \\
85 \text { ens } 43 \\
\text { ol6r } \\
27\end{array}$ & $\begin{array}{r}A F-08 \\
85 \mathrm{cns} 08 \\
011 \mathrm{c} \\
342\end{array}$ & $\begin{array}{r}\text { AF-08 } \\
\text { B5ens.08 } \\
\text { ol 1r } \\
343\end{array}$ & $\begin{array}{r}\text { AF- } 08 \\
85 \mathrm{cns} 08 \\
\text { ol2c } \\
344\end{array}$ & $\begin{array}{r}\text { AF-08 } \\
85 c n s 08 \\
\text { ol } 2 r \\
345\end{array}$ & $\begin{array}{r}s p-02 \\
\text { sp-rs2 } \\
\text { ol 1c } \\
346\end{array}$ & $\begin{array}{r}\text { sp-02 } \\
\text { sp-rs2 } \\
\text { ol 1r } \\
347\end{array}$ & $\begin{array}{r}s p-02 \\
s p-r s 2 \\
o l 2 c \\
348\end{array}$ & $\begin{array}{r}\text { sp-02 } \\
\text { sp-rs2 } \\
\text { ol } 2 r \\
349\end{array}$ & $\begin{array}{r}P C P-A 05 \\
85 \mathrm{cns50} \\
0.017 \mathrm{C} \\
325\end{array}$ & $\begin{array}{r}\text { PCP-h } \\
85 \mathrm{cn} \\
0.01 \\
3\end{array}$ & $\begin{array}{r}P C P-f \\
85 \mathrm{~cm} \\
0.01\end{array}$ & $\begin{array}{r}\text { PCP-A05 } \\
85 \mathrm{cns50} \\
011 \mathrm{C} \\
319\end{array}$ & $\begin{array}{r}\text { PCP-AOS } \\
85 \mathrm{ens50} \\
\text { ol } 1 \mathrm{r} \\
320\end{array}$ & 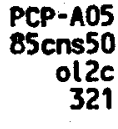 \\
\hline $\begin{array}{l}\text { wtX } \\
\text { Sio2 } \\
\text { TiO2 } \\
\text { Alzo3 } \\
\text { Feo } \\
\text { MnO } \\
\text { MgO } \\
\text { CaO } \\
\text { Cr203 } \\
\text { tot }\end{array}$ & $\begin{array}{r}38.12 \\
0.00 \\
0.05 \\
14.39 \\
0.22 \\
45.68 \\
0.11 \\
98.52\end{array}$ & $\begin{array}{r}37.71 \\
0.00 \\
0.04 \\
17.97 \\
0.37 \\
43.24 \\
0.12 \\
99.41\end{array}$ & $\begin{array}{r}38.39 \\
0.00 \\
0.06 \\
25.01 \\
0.45 \\
37.30 \\
0.16 \\
101.38\end{array}$ & $\begin{array}{r}38.67 \\
0.00 \\
0.08 \\
24.82 \\
0.47 \\
36.89 \\
0.15 \\
101.11\end{array}$ & $\begin{array}{r}36.90 \\
0.00 \\
0.02 \\
27.17 \\
0.51 \\
35.96 \\
0.08 \\
0.01 \\
100.62\end{array}$ & $\begin{array}{r}36.63 \\
0.00 \\
0.04 \\
28.58 \\
0.60 \\
34.90 \\
0.07 \\
0.07 \\
100.78\end{array}$ & $\begin{array}{r}36.88 \\
0.00 \\
0.04 \\
27.33 \\
0.54 \\
35.15 \\
0.07 \\
0.02 \\
99.97\end{array}$ & $\begin{array}{r}36.89 \\
0.03 \\
0.04 \\
27.66 \\
0.49 \\
35.21 \\
0.07 \\
0.01 \\
100.32\end{array}$ & $\begin{array}{r}38.20 \\
0.02 \\
0.02 \\
20.24 \\
0.26 \\
41.96 \\
0.07 \\
0.02 \\
100.73\end{array}$ & $\begin{array}{r}37.80 \\
0.04 \\
0.04 \\
23.04 \\
0.41 \\
39.84 \\
0.10 \\
0.07 \\
101.19\end{array}$ & $\begin{array}{r}38.12 \\
0.00 \\
0.05 \\
22.59 \\
0.36 \\
40.44 \\
0.10 \\
0.00 \\
101.61\end{array}$ & $\begin{array}{r}37.70 \\
0.05 \\
0.02 \\
22.22 \\
0.38 \\
40.51 \\
0.12 \\
0.03 \\
100.93\end{array}$ & $\begin{array}{r}37.10 \\
0.04 \\
0.04 \\
25.59 \\
0.35 \\
36.48 \\
0.17 \\
99.69\end{array}$ & $\begin{array}{r}36.82 \\
0.04 \\
0.02 \\
26.18 \\
0.34 \\
36.40 \\
0.18 \\
99.92\end{array}$ & $\begin{array}{r}36.63 \\
0.05 \\
0.04 \\
25.10 \\
0.40 \\
36.56 \\
0.14 \\
98.83\end{array}$ & $\begin{array}{r}36.67 \\
0.05 \\
0.05 \\
29.16 \\
0.46 \\
33.95 \\
0.14 \\
100.38\end{array}$ & $\begin{array}{r}35.56 \\
0.08 \\
0.16 \\
34.57 \\
0.49 \\
29.61 \\
0.22 \\
100.45\end{array}$ & $\begin{array}{r}36.60 \\
0.00 \\
0.02 \\
28.15 \\
0.37 \\
34.43 \\
0.14 \\
99.69\end{array}$ \\
\hline $\begin{array}{l}\text { atoms/4 } \\
\text { Si } \\
\text { ii } \\
\text { Al } \\
\text { Fe2+ } \\
\text { Mn } \\
\mathrm{Mg} \\
\mathrm{Ca} \\
\mathrm{Ni} \\
\mathrm{Cr}\end{array}$ & $\begin{array}{l}0.9728 \\
0.0000 \\
0.0015 \\
0.3071 \\
0.0048 \\
1.7373 \\
0.0030 \\
0.0000 \\
0.0000 \\
3.0265\end{array}$ & $\begin{array}{l}0.9706 \\
0.0000 \\
0.0012 \\
0.3868 \\
0.0081 \\
1.6587 \\
0.0033 \\
0.0000 \\
0.0000 \\
3.0288\end{array}$ & $\begin{array}{l}0.9975 \\
0.0000 \\
0.0018 \\
0.5435 \\
0.0099 \\
1.4444 \\
0.0045 \\
0.0000 \\
0.0000 \\
3.0016\end{array}$ & $\begin{array}{l}1.0059 \\
0.0000 \\
0.0025 \\
0.5399 \\
0.0104 \\
1.4301 \\
0.0042 \\
0.0000 \\
0.0000\end{array}$ & $\begin{array}{l}0.9796 \\
0.0000 \\
0.0006 \\
0.0032 \\
0.0115 \\
1.4227 \\
0.0023 \\
0.0000 \\
0.0002 \\
3.0200\end{array}$ & $\begin{array}{l}0.9774 \\
0.0000 \\
0.0013 \\
0.6378 \\
0.0136 \\
1.3878 \\
0.0020 \\
0.0000 \\
0.0015 \\
3.0213\end{array}$ & $\begin{array}{l}0.9859 \\
0.0000 \\
0.0013 \\
0.6110 \\
0.0122 \\
1.4004 \\
0.0020 \\
0.0000 \\
0.0004 \\
3.0133\end{array}$ & $\begin{array}{l}0.0006 \\
0.0013 \\
0.6169 \\
0.0111 \\
1.3993 \\
0.0020 \\
0.0000 \\
0.0002 \\
3.0150\end{array}$ & $\begin{array}{l}0.9779 \\
0.0004 \\
0.0006 \\
0.4333 \\
0.0056 \\
1.6009 \\
0.0019 \\
0.0000 \\
0.0004 \\
3.0212\end{array}$ & $\begin{array}{l}0.0 \\
0.0 \\
0.4 \\
0.0 \\
1.5 \\
0.0 \\
0.0 \\
0.0 \\
3.0\end{array}$ & $\begin{array}{l}0.9781 \\
0.0000 \\
0.0015 \\
0.4847 \\
0.0078 \\
1.5463 \\
0.0027 \\
0.0000 \\
0.0000 \\
3.0212\end{array}$ & $\begin{array}{l}0 . \\
0 . \\
0 . \\
0 . \\
1 . \\
0 . \\
0 . \\
0 . \\
3 .\end{array}$ & $\begin{array}{l}5 \\
18 \\
33 \\
15 \\
9 \\
12 \\
8 \\
10 \\
10 \\
10\end{array}$ & & $\begin{array}{l}0 \\
0 \\
0 \\
0 \\
0 \\
0 \\
3\end{array}$ & & $\begin{array}{l}75 \\
17 \\
52 \\
64 \\
14 \\
55 \\
65 \\
00 \\
00 \\
62\end{array}$ & $\begin{array}{l}0 \\
0 \\
0 \\
0 \\
0 \\
0 \\
3\end{array}$ \\
\hline $\begin{array}{l}\text { Fa } \\
\text { Fo }\end{array}$ & $\begin{array}{r}0.150 \\
0.849 \\
84.9\end{array}$ & $\begin{array}{r}0.1891 \\
0.8109 \\
81.09\end{array}$ & $\begin{array}{r}0.2734 \\
0.7266 \\
72.66\end{array}$ & $\begin{array}{r}0.2741 \\
0.7259 \\
72.59\end{array}$ & $\begin{array}{r}0.2978 \\
0.7022 \\
70.22\end{array}$ & $\begin{array}{r}0.3149 \\
0.6851 \\
68.51\end{array}$ & $\begin{array}{r}0.3038 \\
0.6962 \\
69.62\end{array}$ & $\begin{array}{r}0.3060 \\
0.6940 \\
69.40\end{array}$ & $\begin{array}{r}0.2130 \\
0.7870 \\
78.70\end{array}$ & $\begin{array}{r}0.2450 \\
0.7550 \\
75.50\end{array}$ & $\begin{array}{r}0.2387 \\
0.7613 \\
76.13\end{array}$ & $\begin{array}{r}0.2354 \\
0.7646 \\
76.46\end{array}$ & $\begin{array}{l}0.2825 \\
0.7175 \\
79.75\end{array}$ & $\begin{array}{l}0.2876 \\
0.7124 \\
71.24\end{array}$ & $\begin{array}{r}0.2781 \\
0.7219 \\
72.19\end{array}$ & $\begin{array}{r}0.3252 \\
0.6748 \\
67.48\end{array}$ & $\begin{array}{r}0.3958 \\
0.6042 \\
60.42\end{array}$ & $\begin{array}{c}0.68 \\
68 .\end{array}$ \\
\hline
\end{tabular}




\begin{tabular}{|c|c|c|c|c|c|c|c|c|c|c|c|c|c|c|c|c|c|c|}
\hline $\begin{array}{l}\text { Strat\# } \\
\text { Fjeld\# } \\
\text { Grain }\end{array}$ & $\begin{array}{r}\text { PCP-A05 } \\
85 \mathrm{cns50} \\
\text { Ol2r } \\
322\end{array}$ & $\begin{array}{r}\text { PCP-A05 } \\
85 \text { ens50 } \\
\text { ol } 3 c \\
323\end{array}$ & $\begin{array}{r}\text { PCP- } 105 \\
85 e r 550 \\
013 r \\
324\end{array}$ & $\begin{array}{r}P C P-A 05 \\
85 \text { ens50 } \\
\text { ot } 4 \mathrm{C} \\
328\end{array}$ & $\begin{array}{r}\text { PCP- } 105 \\
85 c n s 50 \\
\text { ol } 4 r \\
329\end{array}$ & $\begin{array}{r}\text { PCP-A05 } \\
85 \mathrm{cns50} \\
\text { ol } 5 \mathrm{c} \\
330\end{array}$ & $\begin{array}{r}\text { PCP- } 105 \\
85 \text { ens50 } \\
\text { ol5r } \\
331\end{array}$ & $\begin{array}{r}\text { PCP-A05 } \\
85 \text { cns50 } \\
\text { P1.ol6j } \\
100\end{array}$ & $\begin{array}{c}\text { PCP-A05 } \\
85 \mathrm{C} 550 \\
\text { P2.019.C } \\
332\end{array}$ & $\begin{array}{r}P C P-A 03 \\
85 \mathrm{cns} 52 \\
\text { ol1c } \\
316\end{array}$ & $\begin{array}{r}\text { PCP-A03 } \\
85 \text { ens52 } \\
\text { ol1r } \\
317\end{array}$ & $\begin{array}{r}\text { cP. } 07 \\
85 \mathrm{cns} 60 \\
\text { ol 1c } \\
333\end{array}$ & $\begin{array}{r}\text { cP-07 } \\
85 \mathrm{cns} 60 \\
011 \mathrm{r} \\
334\end{array}$ & $\begin{array}{r}\text { CP-07 } \\
85 \mathrm{cns} 60 \\
012 \mathrm{c} \\
335\end{array}$ & $\begin{array}{r}c P-07 \\
85 \mathrm{cns} 60 \\
012 r \\
336\end{array}$ & $\begin{array}{r}\text { CP-07 } \\
85 \mathrm{cns} 60 \\
013 \mathrm{c} \\
337\end{array}$ & $\begin{array}{r}c p-07 \\
85 \mathrm{cns} 60 \\
013 r \\
338\end{array}$ & $\begin{array}{r}c P-07 \\
85 \mathrm{cns} 60 \\
\text { ol } 4 \mathrm{C} \\
339\end{array}$ \\
\hline $\begin{array}{l}\text { wt\% } \\
\text { sio2 } \\
\text { Tio2 } \\
\text { Al2o3 } \\
\text { Feo } \\
\text { Mno } \\
\text { Mgo } \\
\text { CaO }\end{array}$ & $\begin{array}{r}35.90 \\
0.02 \\
0.04 \\
33.06 \\
0.47 \\
30.72 \\
0.18\end{array}$ & $\begin{array}{r}36.98 \\
0.00 \\
0.67 \\
25.85 \\
0.34 \\
36.79 \\
0.15\end{array}$ & $\begin{array}{r}37.26 \\
0.17 \\
0.65 \\
25.58 \\
0.34 \\
36.45 \\
0.18\end{array}$ & $\begin{array}{r}37.25 \\
0.00 \\
0.05 \\
25.57 \\
0.34 \\
37.20 \\
0.10\end{array}$ & $\begin{array}{r}35.94 \\
0.07 \\
0.05 \\
33.31 \\
0.42 \\
30.49 \\
0.16\end{array}$ & $\begin{array}{r}36.92 \\
0.05 \\
0.05 \\
26.06 \\
0.32 \\
35.51 \\
0.15\end{array}$ & $\begin{array}{r}35.97 \\
0.04 \\
0.05 \\
30.50 \\
0.36 \\
32.35 \\
0.16\end{array}$ & $\begin{array}{r}37.29 \\
0.00 \\
0.04 \\
25.53 \\
0.33 \\
37.20 \\
0.15\end{array}$ & $\begin{array}{r}37.19 \\
0.00 \\
0.00 \\
26.97 \\
0.37 \\
35.52 \\
0.19\end{array}$ & $\begin{array}{r}38.30 \\
0.00 \\
0.04 \\
13.93 \\
0.20 \\
45.75 \\
0.14\end{array}$ & $\begin{array}{r}37.59 \\
0.00 \\
0.05 \\
15.90 \\
0.29 \\
44.03 \\
0.10\end{array}$ & $\begin{array}{r}38.00 \\
0.04 \\
0.05 \\
15.23 \\
0.18 \\
44.88 \\
0.13\end{array}$ & $\begin{array}{r}36.97 \\
0.07 \\
0.04 \\
22.90 \\
0.30 \\
39.01 \\
0.10\end{array}$ & $\begin{array}{r}38.44 \\
0.04 \\
0.05 \\
12.87 \\
0.20 \\
46.64 \\
0.10\end{array}$ & $\begin{array}{r}36.87 \\
0.05 \\
0.02 \\
24.95 \\
0.36 \\
37.66 \\
0.14\end{array}$ & $\begin{array}{r}38.11 \\
0.00 \\
0.04 \\
13.55 \\
0.22 \\
45.52 \\
0.11\end{array}$ & $\begin{array}{r}36.63 \\
0.00 \\
0.05 \\
25.83 \\
0.35 \\
36.43 \\
0.14\end{array}$ & $\begin{array}{r}38.30 \\
0.01 \\
0.04 \\
14.99 \\
0.23 \\
45.08 \\
0.15\end{array}$ \\
\hline $\mathrm{cos}$ & 100.33 & 00.11 & 9.81 & 100.46 & 100.32 & 9.56 & 99.34 & 11.83 & 100.24 & 98.32 & 97.91 & 98.42 & 99.28 & 98.25 & 99.98 & 7.51 & 9.38 & 98.75 \\
\hline $\begin{array}{l}\text { Si } \\
\text { Ai } \\
\text { Fe2+ } \\
\text { Mn } \\
\text { Mg } \\
\text { Ca } \\
\text { Ni } \\
\text { Cr }\end{array}$ & $\begin{array}{l}0.9841 \\
0.0004 \\
0.0013 \\
0.7579 \\
0.0109 \\
1.2550 \\
0.0053 \\
0.0000 \\
0.0000\end{array}$ & $\begin{array}{l}0.9729 \\
0.0000 \\
0.0208 \\
0.5688 \\
0.0076 \\
1.4425 \\
0.0042 \\
0.0000 \\
0.0000\end{array}$ & $\begin{array}{l}0.9797 \\
0.0034 \\
0.0201 \\
0.5625 \\
0.0076 \\
1.4284 \\
0.0051 \\
0.0000 \\
0.0000 \\
3.0068\end{array}$ & $\begin{array}{l}0.9815 \\
0.0000 \\
0.0016 \\
0.5635 \\
0.0076 \\
1.4608 \\
0.0028 \\
0.0000 \\
0.0000\end{array}$ & $\begin{array}{l}0.9853 \\
0.0014 \\
0.0016 \\
0.7638 \\
0.0098 \\
1.2458 \\
0.0047 \\
0.0000 \\
0.0000 \\
3.0124\end{array}$ & $\begin{array}{l}0.9868 \\
0.0010 \\
0.0016 \\
0.5959 \\
0.0072 \\
1.4145 \\
0.0043 \\
0.0000 \\
0.0000 \\
3.0114\end{array}$ & $\begin{array}{l}0.9836 \\
0.0008 \\
0.0016 \\
0.6975 \\
0.0083 \\
1.3183 \\
0.0047 \\
0.0000 \\
0.0000 \\
3.0148\end{array}$ & $\begin{array}{l}0.9821 \\
0.0000 \\
0.0012 \\
0.5623 \\
0.0074 \\
1.4601 \\
0.0042 \\
0.0000 \\
0.0000 \\
\mathbf{3 . 0 1 7 3}\end{array}$ & $\begin{array}{l}0.9892 \\
0.0000 \\
0.0000 \\
0.5999 \\
0.0083 \\
1.4080 \\
0.0054 \\
0.0000 \\
0.0000 \\
3.0108\end{array}$ & $\begin{array}{l}0.9769 \\
0.0000 \\
0.0012 \\
0.2972 \\
0.0043 \\
1.7391 \\
0.0038 \\
0.0000 \\
0.0000 \\
\mathbf{3 . 0 2 2 5}\end{array}$ & $\begin{array}{l}0.9730 \\
0.0000 \\
0.0015 \\
0.3442 \\
0.0064 \\
1.6985 \\
0.0028 \\
0.0000 \\
0.0000 \\
3.0263\end{array}$ & $\begin{array}{l}0.7 \\
0.0 \\
0.0 \\
0.3 \\
0.0 \\
1.7 \\
0.0 \\
0.0 \\
0.0\end{array}$ & $\begin{array}{l}0.0 \\
0.5 \\
0.0 \\
1.5 \\
0.0 \\
0.0 \\
0.0 \\
3.0\end{array}$ & $\begin{array}{l}0.0 \\
0.0 \\
0.2 \\
0.0 \\
1.7 \\
0.0 \\
0.0 \\
0.0 \\
3.0\end{array}$ & $\begin{array}{l}48 \\
10 \\
06 \\
17 \\
31 \\
39 \\
40 \\
00 \\
00 \\
39\end{array}$ & $\begin{array}{l}0 . \\
0 . \\
0 . \\
0 . \\
1 . \\
0 . \\
0 . \\
0 .\end{array}$ & $\begin{array}{l}0 . \\
0 . \\
0 . \\
0 . \\
0 . \\
1 . \\
0 . \\
0 . \\
0 .\end{array}$ & $\begin{array}{l}0 . \\
0 . \\
0 . \\
0 . \\
0 . \\
0 . \\
3 .\end{array}$ \\
\hline $\begin{array}{l}=a \\
=0 \\
=0\end{array}$ & $\begin{array}{r}0.37 \\
0.62 \\
62\end{array}$ & $\begin{array}{r}0.2828 \\
0.7172 \\
71.72\end{array}$ & $\begin{array}{l}0.2825 \\
0.7175 \\
71.75\end{array}$ & $\begin{array}{r}0.2784 \\
0.7216 \\
72.16\end{array}$ & $\begin{array}{r}0.31 \\
0.6 \\
61\end{array}$ & $\begin{array}{l}0.2964 \\
0.7036 \\
70.36\end{array}$ & $\begin{array}{r}0.3460 \\
0.6540 \\
65.40\end{array}$ & $\begin{array}{r}0.2780 \\
0.7220 \\
72.20\end{array}$ & $\begin{array}{r}0.2988 \\
0.7012 \\
70.12\end{array}$ & $\begin{array}{r}0.1459 \\
0.8541 \\
85.41\end{array}$ & $\begin{array}{r}0.1685 \\
0.8315 \\
83.15\end{array}$ & $\begin{array}{l}0.1 \\
0.8 \\
84\end{array}$ & $\begin{array}{l}0.7 \\
0.7\end{array}$ & 8. & 0. & & $\begin{array}{l}0 . \\
0 \\
7\end{array}$ & \\
\hline
\end{tabular}




\begin{tabular}{|c|c|c|c|c|c|c|c|c|c|c|c|c|c|c|c|}
\hline $\begin{array}{l}\text { Strat\# } \\
\text { Field\# } \\
\text { Grain } \\
\text { Anal\# }\end{array}$ & $\begin{array}{r}\text { CP-07 } \\
85 \mathrm{cns} 60 \\
014 \mathrm{r}\end{array}$ & $\begin{array}{r}c P-07 \\
85 \mathrm{cns} 60 \\
\text { ol } 5 \mathrm{c} \\
340\end{array}$ & $\begin{array}{r}\text { cp-07 } \\
85 \mathrm{cns} 60 \\
015 r \\
341\end{array}$ & $\begin{array}{r}c P-07 \\
85 \mathrm{cns} 60 \\
\text { ol6c } \\
356\end{array}$ & $\begin{array}{r}\text { cP-07 } \\
85 \text { cns60 } \\
\text { ot } 6 r \\
357\end{array}$ & $\begin{array}{r}c P-07 \\
85 \mathrm{cns} 60 \\
017 \mathrm{c} \\
355\end{array}$ & $\begin{array}{r}\mathrm{CP}-12 \\
85 \mathrm{cns} 20 \\
\text { ol 19 } \\
350\end{array}$ & $\begin{array}{r}c P-12 \\
85 \mathrm{cns} 20 \\
\text { ol } 1 \mathrm{r} \\
351\end{array}$ & $\begin{array}{r}\mathrm{CP}-12 \\
85 \mathrm{cns} 20 \\
\text { ol } 2 \mathrm{C} \\
352\end{array}$ & $\begin{array}{r}c p-12 \\
85 c n s 20 \\
\text { ol2r } \\
353\end{array}$ & $\begin{array}{r}c P-12 \\
85 c n s 20 \\
0139 \\
354\end{array}$ & $\min$ & $\max$ & mean & sdev \\
\hline $\begin{array}{l}\text { wtX } \\
\text { Sio2 } \\
\text { Tio2 } \\
\text { Alzo3 } \\
\text { Feo } \\
\text { Mno } \\
\text { Mgo } \\
\text { CaO } \\
\text { Cr203 } \\
\text { tot }\end{array}$ & $\begin{array}{r}38.54 \\
0.00 \\
0.02 \\
23.88 \\
0.30 \\
38.44 \\
0.16 \\
101.35\end{array}$ & $\begin{array}{r}38.60 \\
0.04 \\
0.02 \\
14.39 \\
0.16 \\
45.88 \\
0.11 \\
99.14\end{array}$ & $\begin{array}{r}37.11 \\
0.00 \\
0.04 \\
25.36 \\
0.36 \\
37.30 \\
0.15 \\
100.28\end{array}$ & $\begin{array}{r}37.93 \\
0.03 \\
0.05 \\
14.11 \\
0.23 \\
45.29 \\
0.13 \\
0.03 \\
97.69\end{array}$ & $\begin{array}{r}36.89 \\
0.02 \\
0.02 \\
23.91 \\
0.34 \\
38.75 \\
0.17 \\
0.03 \\
100.06\end{array}$ & $\begin{array}{r}38.48 \\
0.00 \\
0.05 \\
15.99 \\
0.29 \\
44.91 \\
0.14 \\
0.03 \\
99.81\end{array}$ & $\begin{array}{r}37.06 \\
0.00 \\
0.11 \\
25.22 \\
0.44 \\
37.15 \\
0.12 \\
0.02 \\
99.99\end{array}$ & $\begin{array}{r}35.92 \\
0.03 \\
0.09 \\
30.81 \\
0.47 \\
32.08 \\
0.05 \\
0.00 \\
99.43\end{array}$ & $\begin{array}{r}36.98 \\
0.00 \\
0.04 \\
26.24 \\
0.47 \\
36.83 \\
0.10 \\
0.08 \\
100.62\end{array}$ & $\begin{array}{r}36.33 \\
0.09 \\
0.04 \\
32.01 \\
0.52 \\
32.36 \\
0.08 \\
0.02 \\
101.30\end{array}$ & $\begin{array}{r}38.18 \\
0.04 \\
0.04 \\
19.17 \\
0.23 \\
42.68 \\
0.12 \\
0.03 \\
100.38\end{array}$ & $\begin{array}{r}35.56 \\
0.00 \\
0.00 \\
12.87 \\
0.16 \\
29.61 \\
0.07 \\
0.00 \\
97.51\end{array}$ & $\begin{array}{r}38.67 \\
0.17 \\
0.67 \\
34.57 \\
0.60 \\
46.64 \\
0.24 \\
0.08 \\
101.83\end{array}$ & $\begin{array}{r}37.29 \\
0.03 \\
0.07 \\
22.81 \\
0.36 \\
39.00 \\
0.14 \\
0.03 \\
99.63\end{array}$ & $\begin{array}{l}0.77 \\
0.03 \\
0.11 \\
5.39 \\
0.10 \\
4.29 \\
0.04 \\
0.02 \\
1.03\end{array}$ \\
\hline $\begin{array}{l}\text { atoms/4 } \\
\text { Si } \\
\text { Ii } \\
\text { Al } \\
\text { Fe2t } \\
\text { Mn } \\
\mathrm{Mg} \\
\mathrm{Ca} \\
\mathrm{Ni} \\
\mathrm{Cr} \\
\text { tot }\end{array}$ & $\begin{array}{l}0.9959 \\
0.0000 \\
0.0006 \\
0.5161 \\
0.0066 \\
1.4803 \\
0.0044 \\
0.0000 \\
0.0000 \\
3.0038\end{array}$ & $\begin{array}{l}0.9775 \\
0.0008 \\
0.0006 \\
0.3048 \\
0.0034 \\
1.7315 \\
0.0030 \\
0.0000 \\
0.0000 \\
3.0215\end{array}$ & $\begin{array}{l}0.9794 \\
0.0000 \\
0.0012 \\
0.5598 \\
0.0080 \\
1.4672 \\
0.0042 \\
0.0000 \\
0.0000 \\
3.0199\end{array}$ & $\begin{array}{l}0.9747 \\
0.0006 \\
0.0015 \\
0.3032 \\
0.0050 \\
1.7345 \\
0.0036 \\
0.0000 \\
0.0006 \\
3.0237\end{array}$ & $\begin{array}{l}0.9702 \\
0.0004 \\
0.0006 \\
0.5259 \\
0.0076 \\
1.5188 \\
0.0048 \\
0.0000 \\
0.0006 \\
3.0288\end{array}$ & $\begin{array}{l}0.9755 \\
0.0000 \\
0.0015 \\
0.3390 \\
0.0062 \\
1.6968 \\
0.0038 \\
0.0000 \\
0.0006 \\
3.0234\end{array}$ & $\begin{array}{l}0.9798 \\
0.0000 \\
0.0034 \\
0.5576 \\
0.0099 \\
1.4638 \\
0.0034 \\
0.0000 \\
0.0004 \\
3.0183\end{array}$ & $\begin{array}{l}0.9829 \\
0.0006 \\
0.0029 \\
0.7051 \\
0.0109 \\
1.3082 \\
0.0044 \\
0.0000 \\
0.0000 \\
3.0150\end{array}$ & $\begin{array}{l}0.9766 \\
0.0000 \\
0.0012 \\
0.5795 \\
0.0105 \\
1.4495 \\
0.0028 \\
0.0000 \\
0.0017 \\
3.0219\end{array}$ & $\begin{array}{l}0 . \\
0 . \\
0 . \\
0 . \\
0 . \\
1 . \\
0 . \\
0 . \\
0 . \\
3 .\end{array}$ & $\begin{array}{l}0.9759 \\
0.0008 \\
0.0012 \\
0.4098 \\
0.0050 \\
1.6259 \\
0.0033 \\
0.0000 \\
0.0006 \\
3.0224\end{array}$ & $\begin{array}{l}0.9697 \\
0.0000 \\
0.0000 \\
0.2732 \\
0.0034 \\
1.2155 \\
0.0019 \\
0.0000 \\
0.0000 \\
2.9929\end{array}$ & $\begin{array}{l}159 \\
134 \\
088 \\
64 \\
136 \\
464 \\
667 \\
000 \\
117 \\
998\end{array}$ & $\begin{array}{l}0.0 \\
0.0 \\
0.5 \\
0.0 \\
1.5 \\
0.0 \\
0.0 \\
0.0 \\
3.0\end{array}$ & \\
\hline $\begin{array}{l}\text { Fa } \\
\text { fo } \\
\text { Mg\# }\end{array}$ & $\begin{array}{r}0.2585 \\
0.7415 \\
74.15\end{array}$ & $\begin{array}{r}0.1497 \\
0.8503 \\
85.03\end{array}$ & $\begin{array}{r}0.2762 \\
0.7238 \\
72.38\end{array}$ & $\begin{array}{r}0.1488 \\
0.8512 \\
85.12\end{array}$ & $\begin{array}{r}0.2572 \\
0.7428 \\
74.28\end{array}$ & $\begin{array}{r}0.1665 \\
0.8335 \\
83.35\end{array}$ & $\begin{array}{r}0.2759 \\
0.7241 \\
72.41\end{array}$ & $\begin{array}{r}0.3502 \\
0.6498 \\
64.98\end{array}$ & $\begin{array}{r}0.2856 \\
0.7144 \\
71.44\end{array}$ & $\begin{array}{r}0.3570 \\
0.6430 \\
64.30\end{array}$ & $\begin{array}{r}0.2013 \\
0.7987 \\
79.87\end{array}$ & $\begin{array}{r}0.1341 \\
0.6042 \\
60.4\end{array}$ & $\begin{array}{r}0.3958 \\
0.8659 \\
86.6\end{array}$ & $\begin{array}{r}0.2487 \\
0.7513 \\
75.1\end{array}$ & $\begin{array}{r}0.06 \\
6\end{array}$ \\
\hline
\end{tabular}




\section{APPENDIX $\nabla$ - Clinopyroxene compositions}

Plagioclase compositons were determined on the JEOL JXA-733 microprobe at Southern Methodist University using standard analytical stratagies and instrumental settings. No attempt was specifically made to optimize the instrumental settings for the determination of minor elements. 
Spurr Volcanic Complex clinopyroxene analyses

\begin{tabular}{|c|c|c|c|c|c|c|c|c|c|c|c|c|c|c|c|c|}
\hline $\begin{array}{l}\text { Strat\# } \\
\text { Field\# } \\
\text { Grain } \\
\text { Anal \# }\end{array}$ & $\begin{array}{r}\text { AMs-803 } \\
85 \mathrm{cns57} \\
\mathrm{c1c} \\
1\end{array}$ & $\begin{array}{r}\text { AMS-B03 } \\
85 \text { ens57 } \\
\text { c1r } \\
2\end{array}$ & $\begin{array}{r}\text { AMS-B03 } \\
85 \mathrm{cns} 57 \\
\mathrm{c} 2 \mathrm{C} \\
3\end{array}$ & $\begin{array}{r}\text { AMS }-803 \\
85 \mathrm{cns} 57 \\
\mathrm{C2r} \\
4\end{array}$ & $\begin{array}{r}\text { AMS-B03 } \\
85 \mathrm{cns} 57 \\
\mathrm{C6c} \\
10\end{array}$ & $\begin{array}{r}\text { AMS-B03 } \\
85 \text { cns57 } \\
\text { C6r } \\
11\end{array}$ & $\begin{array}{r}\text { AMS-B03 } \\
85 \mathrm{cns} 57 \\
c 7 c \\
12\end{array}$ & $\begin{array}{r}\text { AMS-B03 } \\
85 \text { cns57 } \\
\text { C7r } \\
13\end{array}$ & $\begin{array}{r}\text { AMS }-803 \\
85 \mathrm{cns} 57 \\
\mathrm{c8c} \\
14\end{array}$ & $\begin{array}{r}A M S-B 03 \\
85 c n s 57 \\
c 8 r \\
15\end{array}$ & $\begin{array}{r}\text { AMS-B07 } \\
85 \mathrm{cns} 43 \\
\mathrm{C1C} \\
22\end{array}$ & $\begin{array}{r}\text { AMS-B07 } \\
85 \text { ens43 } \\
c 1 r \\
23\end{array}$ & $\begin{array}{r}\text { AMS-807 } \\
85 \text { cns } 43 \\
c 2 c \\
24\end{array}$ & $\begin{array}{r}\text { AMS-B07 } \\
85 \mathrm{cns} 43 \\
\mathrm{c} 2 \mathrm{r} \\
25\end{array}$ & $\begin{array}{r}\text { AMS-807 } \\
85 \mathrm{cns} 43 \\
\mathrm{c3c} \\
28\end{array}$ & $\begin{array}{r}\text { AMs }-807 \\
85 c n s 43 \\
\text { C3r } \\
29\end{array}$ \\
\hline $\begin{array}{l}\text { wty } \\
\text { sio2 } \\
\text { jio2 } \\
\text { Al203 } \\
\text { Fe203 } \\
\text { FeO } \\
\text { MnO } \\
\text { MgO } \\
\text { CaO } \\
\text { Na20 } \\
\text { Cr203 } \\
\text { tot } \\
\text { feO meas }\end{array}$ & $\begin{array}{r}50.80 \\
0.72 \\
4.96 \\
0.98 \\
6.46 \\
0.18 \\
15.74 \\
19.74 \\
0.40 \\
\text { na } \\
99.98 \\
7.34\end{array}$ & $\begin{array}{r}51.79 \\
0.48 \\
1.85 \\
0.95 \\
8.47 \\
0.33 \\
15.21 \\
20.04 \\
0.26 \\
\text { na } \\
99.38 \\
9.32\end{array}$ & $\begin{array}{r}50.81 \\
0.52 \\
4.06 \\
1.40 \\
6.78 \\
0.20 \\
15.03 \\
20.62 \\
0.36 \\
\mathrm{na} \\
99.78 \\
8.04\end{array}$ & $\begin{array}{r}51.88 \\
0.45 \\
1.90 \\
1.00 \\
8.73 \\
0.25 \\
15.84 \\
19.14 \\
0.25 \\
\text { na } \\
99.44 \\
9.63\end{array}$ & $\begin{array}{r}52.61 \\
0.47 \\
1.41 \\
0.82 \\
8.43 \\
0.34 \\
15.45 \\
20.44 \\
0.26 \\
\text { na } \\
100.22 \\
9.16\end{array}$ & $\begin{array}{r}52.20 \\
0.40 \\
2.82 \\
0.84 \\
6.51 \\
0.25 \\
16.47 \\
20.02 \\
0.30 \\
\text { na } \\
99.80 \\
7.26\end{array}$ & $\begin{array}{r}52.75 \\
0.35 \\
2.41 \\
0.36 \\
4.81 \\
0.16 \\
17.21 \\
20.77 \\
0.28 \\
\mathrm{na} \\
99.10 \\
5.13\end{array}$ & $\begin{array}{r}52.30 \\
0.44 \\
1.91 \\
0.57 \\
9.24 \\
0.30 \\
15.65 \\
19.09 \\
0.28 \\
99 \\
99.78 \\
9.75\end{array}$ & $\begin{array}{r}52.87 \\
0.26 \\
1.20 \\
0.38 \\
9.37 \\
0.47 \\
14.38 \\
20.74 \\
0.34 \\
\text { na } \\
100.01 \\
9.71\end{array}$ & $\begin{array}{r}52.25 \\
0.36 \\
1.10 \\
0.08 \\
11.25 \\
0.36 \\
13.56 \\
20.11 \\
0.28 \\
99 \\
99.35 \\
11.32\end{array}$ & $\begin{array}{r}53.07 \\
0.45 \\
2.34 \\
0.37 \\
5.18 \\
0.17 \\
17.20 \\
21.19 \\
0.19 \\
\text { na } \\
100.16 \\
5.51\end{array}$ & $\begin{array}{r}53.28 \\
0.41 \\
2.52 \\
0.47 \\
5.28 \\
0.17 \\
17.55 \\
20.79 \\
0.20 \\
\mathrm{na} \\
100.67 \\
5.70\end{array}$ & $\begin{array}{r}51.21 \\
0.72 \\
3.22 \\
1.26 \\
6.61 \\
0.20 \\
15.20 \\
21.09 \\
0.33 \\
n a \\
99.84 \\
7.74\end{array}$ & $\begin{array}{r}51.79 \\
0.63 \\
2.17 \\
1.27 \\
6.57 \\
0.23 \\
15.93 \\
20.78 \\
0.27 \\
99 \\
99.64 \\
7.71\end{array}$ & $\begin{array}{r}52.02 \\
0.60 \\
3.19 \\
1.02 \\
4.63 \\
0.12 \\
16.20 \\
22.18 \\
0.25 \\
\text { na } \\
100.21 \\
5.55\end{array}$ & $\begin{array}{r}52.88 \\
0.38 \\
2.05 \\
0.61 \\
6.39 \\
0.21 \\
16.63 \\
20.72 \\
0.23 \\
\mathrm{na} \\
100.10 \\
6.94\end{array}$ \\
\hline $\begin{array}{l}\text { atoms/6 } \\
\text { si } \\
\text { Ii } \\
\text { Al t } \\
\text { Al o } \\
\text { Fez+ } \\
\text { Fe2+ } \\
\text { Mn } \\
\text { Mg } \\
\text { Ca } \\
\mathrm{Ma} \\
\text { Mi } \\
\mathrm{Cr} \\
\text { tot }\end{array}$ & $\begin{array}{l}1.8729 \\
0.0200 \\
0.1271 \\
0.0885 \\
0.0273 \\
0.1990 \\
0.0056 \\
0.8648 \\
0.7798 \\
0.0286 \\
0.0000 \\
0.0000 \\
4.0136\end{array}$ & $\begin{array}{l}1.9416 \\
0.0135 \\
0.0584 \\
0.0234 \\
0.0268 \\
0.2654 \\
0.0105 \\
0.8498 \\
0.8050 \\
0.0189 \\
0.0000 \\
0.0000 \\
4.0134\end{array}$ & $\begin{array}{l}1.8898 \\
0.0145 \\
0.1102 \\
0.0678 \\
0.0392 \\
0.2109 \\
0.0063 \\
0.8331 \\
0.8218 \\
0.0260 \\
0.0000 \\
0.0000 \\
4.0196\end{array}$ & $\begin{array}{l}1.9404 \\
0.0127 \\
0.0596 \\
0.0242 \\
0.0282 \\
0.2730 \\
0.0079 \\
0.8829 \\
0.7671 \\
0.0181 \\
0.0000 \\
0.0000 \\
4.0141\end{array}$ & $\begin{array}{l}1.9540 \\
0.0131 \\
0.0460 \\
0.0157 \\
0.0228 \\
0.2617 \\
0.0107 \\
0.8552 \\
0.8134 \\
0.0187 \\
0.0000 \\
0.0000 \\
4.0114\end{array}$ & $\begin{array}{l}1.9267 \\
0.0111 \\
0.0733 \\
0.0494 \\
0.0232 \\
0.2009 \\
0.0078 \\
0.9060 \\
0.7918 \\
0.0215 \\
0.0000 \\
0.0000 \\
4.0116\end{array}$ & $\begin{array}{l}1.9430 \\
0.0097 \\
0.0570 \\
0.0477 \\
0.0099 \\
0.1482 \\
0.0050 \\
0.9448 \\
0.8198 \\
0.0200 \\
0.0000 \\
0.0000 \\
4.0049\end{array}$ & $\begin{array}{l}79 \\
23 \\
21 \\
17 \\
59 \\
78 \\
95 \\
87 \\
18 \\
02 \\
00 \\
00 \\
80\end{array}$ & 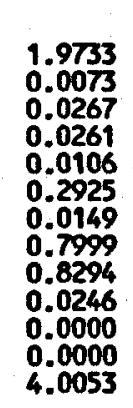 & $\begin{array}{l}43 \\
02 \\
57 \\
33 \\
24 \\
54 \\
15 \\
36 \\
42 \\
05 \\
00 \\
00 \\
12\end{array}$ & $\begin{array}{l}0 . \\
0 . \\
0 . \\
0 . \\
0 . \\
0 . \\
0 . \\
0 . \\
0 .\end{array}$ & & & & & $\begin{array}{l}0 \\
0 \\
0 \\
0 \\
0 \\
0 \\
0 \\
0 \\
0 \\
0\end{array}$ \\
\hline $\begin{array}{l}\text { Ac } \\
\text { Jd } \\
\text { FeCaTs } \\
\text { CrCaTs } \\
\text { AlCats }\end{array}$ & $\begin{array}{l}0.0273 \\
0.0013 \\
0.0000 \\
0.0000 \\
0.0872\end{array}$ & $\begin{array}{l}0.0000 \\
0.0079 \\
0.0000 \\
0.0234\end{array}$ & $\begin{array}{l}0.0260 \\
0.0000 \\
0.0133 \\
0.0000 \\
0.0678\end{array}$ & $\begin{array}{l}0.0 \\
0.0 \\
0.0 \\
0.0\end{array}$ & $\begin{array}{l}0.0187 \\
0.0000 \\
0.0041 \\
0.0000 \\
0.0157\end{array}$ & $\begin{array}{l}0.0000 \\
0.0017 \\
0.0000 \\
0.0494\end{array}$ & $\begin{array}{l}0.0 \\
0.0 \\
0.0 \\
0.0\end{array}$ & $\begin{array}{l}0.1 \\
0.1 \\
0.1 \\
0 . \\
0 .\end{array}$ & $\begin{array}{l}0 . \\
0 . \\
0 . \\
0 .\end{array}$ & $\begin{array}{l}11 \\
10 \\
12\end{array}$ & $\begin{array}{l}2 \\
2 \\
0 \\
0\end{array}$ & & & & & \\
\hline $\begin{array}{l}\text { Wo } \\
\text { En } \\
\text { Fs }\end{array}$ & $\begin{array}{r}0.3600 \\
0.5203 \\
0.1197 \\
81.3\end{array}$ & $\begin{array}{r}0.3963 \\
0.4600 \\
0.1437 \\
76.2\end{array}$ & $\begin{array}{l}0.3833 \\
0.4921 \\
0.1246 \\
79.8\end{array}$ & $\begin{array}{r}0.3755 \\
0.4770 \\
0.1475 \\
76.4\end{array}$ & $\begin{array}{l}0.4062 \\
0.4547 \\
0.1391 \\
76.6\end{array}$ & $\begin{array}{r}0.3811 \\
0.5066 \\
0.1123 \\
81.9\end{array}$ & $\begin{array}{l}0.3960 \\
0.5221 \\
0.0819 \\
86.4\end{array}$ & $\begin{array}{r}0.3752 \\
0.4694 \\
0.1555 \\
75.1\end{array}$ & $\begin{array}{r}0.4291 \\
0.1569 \\
73.2\end{array}$ & $\begin{array}{r}0.4056 \\
0.4056 \\
0.18887 \\
68.2\end{array}$ & $\begin{array}{r}0.4017 \\
0.5119 \\
0.0864 \\
85.6\end{array}$ & $\begin{array}{r}0.3900 \\
0.5220 \\
0.0881 \\
85.6\end{array}$ & $\begin{array}{r}0.4038 \\
0.4793 \\
0.1169 \\
80.4\end{array}$ & $\begin{array}{r}0.4049 \\
0.4833 \\
0.1118 \\
81.2\end{array}$ & & $\begin{array}{r}0.494 \\
0.106 \\
82 .\end{array}$ \\
\hline
\end{tabular}




\begin{tabular}{|c|c|c|c|c|c|c|c|c|c|c|c|c|c|c|c|c|}
\hline $\begin{array}{l}\text { Strat\# } \\
\text { Field\# } \\
\text { Grain } \\
\text { Anal\# }\end{array}$ & $\begin{array}{r}A M 5-807 \\
85 \mathrm{cns} 43 \\
64 \mathrm{C} \\
30\end{array}$ & $\begin{array}{r}A M S-807 \\
85 \mathrm{cns} 43 \\
\mathrm{c} 4 \mathrm{r} \\
31\end{array}$ & $\begin{array}{r}\text { Ams-807 } \\
85 \mathrm{cns} 43 \\
\mathrm{c5c} \\
32\end{array}$ & $\begin{array}{r}\text { AMs-B } 07 \\
85 \text { cns } 43 \\
\text { c5r } \\
33\end{array}$ & $\begin{array}{r}\text { A4s-A03 } \\
85 \mathrm{cns} 23 \\
\mathrm{clc} \\
44\end{array}$ & $\begin{array}{r}A M S-A 03 \\
85 \mathrm{cns} 23 \\
c 1 \mathrm{r} \\
45\end{array}$ & $\begin{array}{r}\text { AMs }-103 \\
85 \mathrm{cns} 23 \\
\mathrm{c2c} \\
46\end{array}$ & $\begin{array}{r}\text { AMS }-A 03 \\
85 \mathrm{cns} 23 \\
\mathrm{C2r} \\
47\end{array}$ & $\begin{array}{r}\text { AMS-A03 } \\
85 \text { ens } 23 \\
C 3 c \\
48\end{array}$ & $\begin{array}{r}\text { AMS-A03 } \\
85 \text { ens } 23 \\
\text { C3r } \\
49\end{array}$ & $\begin{array}{r}\text { AMs- } 103 \\
85 \mathrm{cns} 23 \\
\mathrm{c4c} \\
52\end{array}$ & $\begin{array}{r}\text { AMS- } A 03 \\
85 \mathrm{cns} 23 \\
\mathrm{c4r} \\
53\end{array}$ & $\begin{array}{r}\text { AMs- } 103 \\
85 \mathrm{cns} 23 \\
5 \mathrm{c} c \\
54\end{array}$ & $\begin{array}{r}\text { AMs- } 103 \\
85 \mathrm{cns} 23 \\
\mathrm{c5r} \\
55\end{array}$ & $\begin{array}{r}A M S-103 \\
85 \mathrm{cns23} \\
c 8=02 \mathrm{j} \\
61\end{array}$ & $\begin{array}{r}\text { AMS-A03 } \\
85 \text { cns23 } \\
P . c 6 c \\
50\end{array}$ \\
\hline $\begin{array}{l}\text { wtX } \\
\text { sio2 } \\
\text { Tio2 } \\
\text { Alzo3 } \\
\text { Fezo3 } \\
\text { FeO } \\
\text { Mino } \\
\text { MgO } \\
\text { CaO } \\
\text { Nazo } \\
\text { Cr203 } \\
\text { tot } \\
\text { FeO meas }\end{array}$ & $\begin{array}{r}51.62 \\
0.66 \\
2.44 \\
1.48 \\
7.87 \\
0.27 \\
14.78 \\
20.94 \\
0.36 \\
\mathrm{na} \\
100.43 \\
9.21\end{array}$ & $\begin{array}{r}50.97 \\
0.65 \\
3.84 \\
1.42 \\
5.90 \\
0.20 \\
15.89 \\
20.57 \\
0.30 \\
99.74 \\
7.18\end{array}$ & $\begin{array}{r}51.93 \\
0.70 \\
2.91 \\
1.01 \\
7.89 \\
0.28 \\
15.48 \\
20.35 \\
0.29 \\
\text { na } \\
100.84 \\
8.80\end{array}$ & $\begin{array}{r}51.15 \\
0.53 \\
4.32 \\
1.19 \\
4.92 \\
0.16 \\
15.65 \\
21.63 \\
0.32 \\
\text { na } \\
99.87 \\
5.99\end{array}$ & $\begin{array}{r}51.86 \\
0.48 \\
1.77 \\
1.25 \\
9.11 \\
0.34 \\
14.17 \\
20.82 \\
0.35 \\
\text { na } \\
100.15 \\
10.23\end{array}$ & $\begin{array}{r}52.38 \\
0.49 \\
1.75 \\
0.91 \\
9.59 \\
0.35 \\
14.06 \\
20.82 \\
0.39 \\
\text { na } \\
100.74 \\
10.41\end{array}$ & $\begin{array}{r}52.66 \\
0.38 \\
1.57 \\
0.94 \\
9.14 \\
0.42 \\
14.28 \\
21.04 \\
0.38 \\
n a \\
100.80 \\
9.98\end{array}$ & $\begin{array}{r}51.95 \\
0.45 \\
1.55 \\
0.65 \\
8.45 \\
0.38 \\
14.29 \\
21.17 \\
0.30 \\
n \mathrm{na} \\
99.20 \\
9.04\end{array}$ & $\begin{array}{r}51.93 \\
0.42 \\
1.45 \\
1.71 \\
7.86 \\
0.35 \\
14.52 \\
21.52 \\
0.34 \\
\mathrm{na} \\
100.10 \\
9.40\end{array}$ & $\begin{array}{r}52.27 \\
0.37 \\
1.43 \\
1.33 \\
8.44 \\
0.37 \\
14.50 \\
21.23 \\
0.34 \\
\text { na } \\
100.28 \\
9.64\end{array}$ & $\begin{array}{r}52.85 \\
0.34 \\
1.17 \\
0.82 \\
8.87 \\
0.38 \\
14.60 \\
21.20 \\
0.31 \\
\text { na } \\
100.54 \\
9.61\end{array}$ & $\begin{array}{r}53.32 \\
0.36 \\
1.44 \\
0.47 \\
8.54 \\
0.34 \\
14.85 \\
21.36 \\
0.34 \\
\mathrm{na} \\
101.02 \\
8.96\end{array}$ & $\begin{array}{r}51.52 \\
0.55 \\
2.13 \\
1.58 \\
8.26 \\
0.38 \\
14.56 \\
20.72 \\
0.36 \\
n a \\
100.06 \\
9.68\end{array}$ & $\begin{array}{r}52.40 \\
0.43 \\
1.78 \\
1.18 \\
8.50 \\
0.39 \\
14.66 \\
20.98 \\
0.36 \\
\text { na } \\
100.68 \\
9.56\end{array}$ & $\begin{array}{r}51.64 \\
0.32 \\
0.99 \\
1.82 \\
7.30 \\
0.45 \\
14.69 \\
21.70 \\
0.29 \\
n \text { na } \\
99.20 \\
8.94\end{array}$ & $\begin{array}{r}52.44 \\
0.49 \\
2.13 \\
0.78 \\
7.57 \\
0.30 \\
14.69 \\
21.82 \\
0.32 \\
100.54 \\
8.27\end{array}$ \\
\hline $\begin{array}{l}\text { atoms/6 } \\
\text { si } \\
\text { Ti } \\
\text { Al t } \\
\text { Al o } \\
\text { Fez+ } \\
\text { Fe2+ } \\
\mathrm{Mn} \\
\mathrm{Mg} \\
\mathrm{Ca} \\
\mathrm{Ma} \\
\mathrm{Ni} \\
\mathrm{Cr} \\
\text { tot }\end{array}$ & $\begin{array}{l}1.9202 \\
0.0185 \\
0.0798 \\
0.0272 \\
0.0415 \\
0.2450 \\
0.0085 \\
0.8194 \\
0.8347 \\
0.0260 \\
0.0000 \\
0.0000 \\
4.0208\end{array}$ & $\begin{array}{l}1.8890 \\
0.0181 \\
0.1110 \\
0.0568 \\
0.0396 \\
0.1830 \\
0.0063 \\
0.8777 \\
0.8169 \\
0.0216 \\
0.0000 \\
0.0000 \\
4.0198\end{array}$ & $\begin{array}{l}1.9137 \\
0.0194 \\
0.0863 \\
0.0402 \\
0.0280 \\
0.2432 \\
0.0087 \\
0.8502 \\
0.8036 \\
0.0207 \\
0.0000 \\
0.0000 \\
4.0140\end{array}$ & $\begin{array}{l}1.8864 \\
0.0147 \\
0.1136 \\
0.0742 \\
0.0329 \\
0.1519 \\
0.0050 \\
0.8602 \\
0.8547 \\
0.0229 \\
0.0000 \\
0.0000 \\
4.0164\end{array}$ & $\begin{array}{l}1.9425 \\
0.0135 \\
0.0575 \\
0.0207 \\
0.0351 \\
0.2853 \\
0.0108 \\
0.7910 \\
0.8356 \\
0.0254 \\
0.0000 \\
0.0000 \\
4.0176\end{array}$ & $\begin{array}{l}1.9492 \\
0.0137 \\
0.0508 \\
0.0260 \\
0.0255 \\
0.2984 \\
0.0110 \\
0.7798 \\
0.8302 \\
0.0281 \\
0.0000 \\
0.0000 \\
4.0128\end{array}$ & $\begin{array}{l}1.9556 \\
0.0106 \\
0.0444 \\
0.0244 \\
0.0262 \\
0.2838 \\
0.0132 \\
0.7903 \\
0.8372 \\
0.0274 \\
0.0000 \\
0.0000 \\
4.0131\end{array}$ & $\begin{array}{l}1.9546 \\
0.0127 \\
0.0454 \\
0.0233 \\
0.0185 \\
0.2659 \\
0.0121 \\
0.8013 \\
0.8535 \\
0.0219 \\
0.0000 \\
0.0000 \\
4.0093\end{array}$ & $\begin{array}{l}1.9444 \\
0.0118 \\
0.0556 \\
0.0084 \\
0.0481 \\
0.2462 \\
0.0111 \\
0.8103 \\
0.8634 \\
0.0247 \\
0.0000 \\
0.0000 \\
4.0241\end{array}$ & $\begin{array}{l}1.9517 \\
0.0104 \\
0.0483 \\
0.0147 \\
0.0374 \\
0.2636 \\
0.0117 \\
0.8069 \\
0.8494 \\
0.0246 \\
0.0000 \\
0.0000 \\
4.0187\end{array}$ & $\begin{array}{l}1.9645 \\
0.0095 \\
0.03555 \\
0.0158 \\
0.0230 \\
0.2757 \\
0.0120 \\
0.8088 \\
0.8444 \\
0.0223 \\
0.0000 \\
0.0000 \\
4.0115\end{array}$ & $\begin{array}{l}1.9644 \\
0.0100 \\
0.0356 \\
0.0270 \\
0.0130 \\
0.2631 \\
0.0106 \\
0.8154 \\
0.8432 \\
0.0243 \\
0.0000 \\
0.0000 \\
4.0065\end{array}$ & $\begin{array}{l}1.9284 \\
0.0155 \\
0.0716 \\
0.0224 \\
0.0444 \\
0.2586 \\
0.0120 \\
0.8122 \\
0.8310 \\
0.0261 \\
0.0000 \\
0.0000 \\
4.0222\end{array}$ & $\begin{array}{l}56 \\
20 \\
44 \\
35 \\
28 \\
40 \\
23 \\
12 \\
47 \\
59 \\
00 \\
00 \\
64\end{array}$ & & \\
\hline $\begin{array}{l}\text { Ac } \\
\text { Jd } \\
\text { FeCaTs } \\
\text { CrCaTs } \\
\text { AlCaTs }\end{array}$ & $\begin{array}{l}0.0260 \\
0.0000 \\
0.0156 \\
0.0000 \\
0.0272\end{array}$ & $\begin{array}{l}0.0216 \\
0.0000 \\
0.0180 \\
0.0000 \\
0.0568\end{array}$ & $\begin{array}{l}0.0207 \\
0.0000 \\
0.0073 \\
0.0000 \\
0.0402\end{array}$ & $\begin{array}{l}0.0229 \\
0.0000 \\
0.0100 \\
0.0000 \\
0.0742\end{array}$ & $\begin{array}{l}0.0254 \\
0.0000 \\
0.0097 \\
0.0000 \\
0.0207\end{array}$ & $\begin{array}{l}0.0255 \\
0.0026 \\
0.0000 \\
0.0000 \\
0.0234\end{array}$ & $\begin{array}{l}0.0262 \\
0.0012 \\
0.0000 \\
0.0000 \\
0.0232\end{array}$ & $\begin{array}{l}0.0185 \\
0.0034 \\
0.0000 \\
0.0000 \\
0.0200\end{array}$ & $\begin{array}{l}0.0247 \\
0.0000 \\
0.0235 \\
0.0000 \\
0.0084\end{array}$ & $\begin{array}{l}0.0246 \\
0.0000 \\
0.0128 \\
0.0000 \\
0.0147\end{array}$ & $\begin{array}{l}0.0 \\
0.0 \\
0.0 \\
0.0 \\
0.0\end{array}$ & $\begin{array}{l}0.0 \\
0.0 \\
0.0 \\
0.0 \\
0.0\end{array}$ & $\begin{array}{l}0.1 \\
0.1 \\
0.1 \\
0.1\end{array}$ & $\begin{array}{l}0.0259 \\
0.0000 \\
0.0069 \\
0.0000 \\
0.0235\end{array}$ & & \\
\hline $\begin{array}{l}\text { Wo } \\
\text { En } \\
\text { Fs } \\
\text { Mg\# }\end{array}$ & $\begin{array}{r}0.4089 \\
0.4551 \\
0.1361 \\
77.0\end{array}$ & $\begin{array}{r}0.3818 \\
0.5115 \\
0.1067 \\
82.7\end{array}$ & $\begin{array}{r}0.3884 \\
0.4756 \\
0.1360 \\
77.8\end{array}$ & $\begin{array}{r}0.3967 \\
0.5128 \\
0.0905 \\
85.0\end{array}$ & $\begin{array}{r}0.4153 \\
0.4297 \\
0.1550 \\
73.5\end{array}$ & $\begin{array}{r}0.4162 \\
0.4222 \\
0.1616 \\
72.3\end{array}$ & $\begin{array}{r}0.4201 \\
0.4267 \\
0.1532 \\
73.6\end{array}$ & $\begin{array}{l}0.4260 \\
0.4310 \\
0.1430 \\
75.1\end{array}$ & $\begin{array}{r}0.4281 \\
0.4386 \\
0.1333 \\
76.7\end{array}$ & $\begin{array}{r}0.4233 \\
0.4347 \\
0.1420 \\
75.4\end{array}$ & $\begin{array}{r}0.4251 \\
0.4287 \\
0.1461 \\
74.6\end{array}$ & $\begin{array}{r}0.4203 \\
0.4383 \\
0.1414 \\
75.6\end{array}$ & $\begin{array}{r}0.4082 \\
0.4489 \\
0.1429 \\
75.9\end{array}$ & $\begin{array}{r}0.4151 \\
0.4413 \\
0.1436 \\
75.4\end{array}$ & $\begin{array}{l}0.4346 \\
0.4421 \\
0.1233 \\
78.2\end{array}$ & $\begin{array}{l}0.4273 \\
0.4442 \\
0.1285 \\
7.6\end{array}$ \\
\hline
\end{tabular}




\begin{tabular}{|c|c|c|c|c|c|c|c|c|c|c|c|c|c|c|c|c|}
\hline $\begin{array}{l}\text { Strat\# } \\
\text { Field\#\# } \\
\text { Grain } \\
\text { Anal\# }\end{array}$ & $\begin{array}{r}\text { ANS-A03 } \\
85 \mathrm{cns} 23 \\
\text { P.c7r } \\
51\end{array}$ & $\begin{array}{r}\text { AMS- } 104 \\
85 \mathrm{cns} 22 \\
\mathrm{c1c} \\
34\end{array}$ & $\begin{array}{r}\text { AMS-A04 } \\
85 \mathrm{cns} 22 \\
\mathrm{c1r} \\
35\end{array}$ & $\begin{array}{r}\text { AMs- } 104 \\
85 \mathrm{cns} 22 \\
\mathrm{c2c} \\
36\end{array}$ & $\begin{array}{r}\text { AMs-104 } \\
85 \mathrm{ens} 22 \\
\mathrm{C2r} \\
37\end{array}$ & $\begin{array}{r}\text { AMS-A04 } \\
85 \text { cns22 } \\
\text { C3c } \\
38\end{array}$ & $\begin{array}{r}\text { AMS-A04 } \\
85 \mathrm{cns} 22 \\
\mathrm{c3r} \\
39\end{array}$ & $\begin{array}{r}\text { AMS- } 104 \\
85 \text { cns22 } \\
c 4 c \\
40\end{array}$ & $\begin{array}{r}\text { AMS-A04 } \\
85 \mathrm{cns} 22 \\
\text { C4r } \\
41\end{array}$ & $\begin{array}{r}\text { AMS- } 104 \\
85 \mathrm{cns22} \\
\mathrm{c5c} \\
42\end{array}$ & $\begin{array}{r}\text { AMs-A04 } \\
85 \mathrm{cns} 22 \\
\mathrm{C5r} \\
43\end{array}$ & $\begin{array}{r}s p-02 \\
s p-r s 2 \\
c 1 c \\
210\end{array}$ & $\begin{array}{r}s p-02 \\
s p-r s 2 \\
c 1 r \\
211\end{array}$ & $\begin{array}{r}5 p-02 \\
s p-r 82 \\
c 2 c \\
212\end{array}$ & $\begin{array}{r}s p-02 \\
s p-r s 2 \\
c 2 r \\
213\end{array}$ & $\begin{array}{r}s p-02 \\
s p-r s 2 \\
c 3 c \\
214\end{array}$ \\
\hline $\begin{array}{l}\text { HtK } \\
\text { sio2 } \\
\text { Tio2 } \\
\text { Al203 } \\
\text { fe203 } \\
\text { Feo } \\
\text { Mro } \\
\text { MgO } \\
\text { CaO } \\
\text { Ma20 } \\
\text { Cr203 } \\
\text { tot } \\
\text { Feo meas }\end{array}$ & $\begin{array}{r}52.64 \\
0.30 \\
1.45 \\
0.49 \\
9.05 \\
0.40 \\
14.34 \\
20.92 \\
0.35 \\
\text { na } \\
99.94 \\
9.49\end{array}$ & $\begin{array}{r}51.77 \\
0.73 \\
2.99 \\
1.45 \\
5.88 \\
0.20 \\
15.91 \\
21.52 \\
0.26 \\
\text { na } \\
100.71 \\
7.18\end{array}$ & $\begin{array}{r}50.88 \\
0.82 \\
3.07 \\
1.92 \\
6.45 \\
0.18 \\
15.41 \\
21.07 \\
0.29 \\
\mathrm{na} \\
100.09 \\
8.18\end{array}$ & $\begin{array}{r}51.07 \\
0.74 \\
2.47 \\
1.90 \\
7.00 \\
0.25 \\
15.64 \\
20.28 \\
0.32 \\
\text { na } \\
99.67 \\
8.71\end{array}$ & $\begin{array}{r}51.69 \\
0.66 \\
2.94 \\
1.03 \\
6.07 \\
0.20 \\
15.41 \\
21.76 \\
0.27 \\
\text { na } \\
100.03 \\
7.00\end{array}$ & $\begin{array}{r}51.13 \\
0.84 \\
3.16 \\
1.30 \\
7.93 \\
0.23 \\
15.14 \\
20.03 \\
0.36 \\
\text { na } \\
100.12 \\
9.10\end{array}$ & $\begin{array}{r}52.13 \\
0.45 \\
2.07 \\
0.88 \\
7.28 \\
0.28 \\
16.01 \\
20.27 \\
0.23 \\
n a \\
99.61 \\
8.08\end{array}$ & $\begin{array}{r}51.90 \\
0.71 \\
2.01 \\
1.29 \\
7.72 \\
0.30 \\
15.86 \\
20.02 \\
0.29 \\
\text { na } \\
100.10 \\
8.88\end{array}$ & $\begin{array}{r}51.82 \\
0.50 \\
2.68 \\
1.17 \\
5.52 \\
0.18 \\
15.68 \\
21.89 \\
0.27 \\
\text { na } \\
99.71 \\
6.57\end{array}$ & $\begin{array}{r}50.57 \\
0.74 \\
3.63 \\
2.64 \\
4.32 \\
0.21 \\
15.66 \\
22.27 \\
0.29 \\
100.34 \\
100 \\
6.70\end{array}$ & $\begin{array}{r}50.18 \\
1.23 \\
4.03 \\
1.57 \\
7.33 \\
0.21 \\
14.74 \\
20.77 \\
0.30 \\
100.37 \\
100 \\
8.75\end{array}$ & $\begin{array}{r}52.70 \\
0.29 \\
1.32 \\
1.18 \\
8.41 \\
0.35 \\
14.75 \\
21.14 \\
0.36 \\
0.02 \\
100.53 \\
9.48\end{array}$ & $\begin{array}{r}53.53 \\
0.30 \\
1.32 \\
0.91 \\
8.57 \\
0.40 \\
15.18 \\
21.25 \\
0.31 \\
0.00 \\
101.77 \\
9.39\end{array}$ & $\begin{array}{r}52.46 \\
0.48 \\
1.63 \\
1.24 \\
9.46 \\
0.33 \\
14.50 \\
20.36 \\
0.43 \\
0.04 \\
100.93 \\
10.58\end{array}$ & $\begin{array}{r}52.75 \\
0.31 \\
1.21 \\
1.66 \\
7.69 \\
0.38 \\
15.98 \\
20.67 \\
0.23 \\
0.07 \\
100.95 \\
9.18\end{array}$ & $\begin{array}{r}53.02 \\
0.21 \\
1.24 \\
1.34 \\
8.82 \\
0.43 \\
14.80 \\
21.06 \\
0.34 \\
0.00 \\
101.25 \\
10.02\end{array}$ \\
\hline $\begin{array}{l}\text { atoms/6 } \\
\text { Si } \\
\text { Ti } \\
\text { Al t } \\
\text { Al o } \\
\text { Fejt } \\
\text { Fe2+ } \\
\mathrm{Mn} \\
\mathrm{Mg} \\
\mathrm{Ca} \\
\mathrm{Na} \\
\mathrm{Mi} \\
\mathrm{Cr} \\
\text { tot }\end{array}$ & $\begin{array}{l}1.9654 \\
0.0084 \\
0.0346 \\
0.0293 \\
0.0138 \\
0.2825 \\
0.0127 \\
0.7979 \\
0.8369 \\
0.0253 \\
0.0000 \\
0.0000 \\
4.0069\end{array}$ & $\begin{array}{l}1.9042 \\
0.0202 \\
0.0958 \\
0.0339 \\
0.0401 \\
0.1808 \\
0.0062 \\
0.8722 \\
0.8482 \\
0.0185 \\
0.0000 \\
0.0000 \\
4.0200\end{array}$ & $\begin{array}{l}1.8933 \\
0.0229 \\
0.1067 \\
0.0280 \\
0.0537 \\
0.2009 \\
0.0057 \\
0.8546 \\
0.8401 \\
0.0209 \\
0.0000 \\
0.0000 \\
4.0268\end{array}$ & $\begin{array}{l}1.9096 \\
0.0208 \\
0.0904 \\
0.0184 \\
0.0536 \\
0.2188 \\
0.0079 \\
0.8715 \\
0.8125 \\
0.0232 \\
0.0000 \\
0.0000 \\
4.0268\end{array}$ & $\begin{array}{l}1.9128 \\
0.0184 \\
0.0872 \\
0.0411 \\
0.0288 \\
0.1879 \\
0.0063 \\
0.8499 \\
0.8628 \\
0.0194 \\
0.0000 \\
0.0000\end{array}$ & $\begin{array}{l}1.9020 \\
0.0235 \\
0.0980 \\
0.0406 \\
0.0363 \\
0.2468 \\
0.0072 \\
0.8394 \\
0.7984 \\
0.0260 \\
0.0000 \\
0.0000 \\
4.0182\end{array}$ & $\begin{array}{l}1.9380 \\
0.0126 \\
0.0620 \\
0.0287 \\
0.0247 \\
0.2265 \\
0.0088 \\
0.8870 \\
0.8074 \\
0.0166 \\
0.0000 \\
0.0000 \\
4.0124\end{array}$ & $\begin{array}{l}1.9285 \\
0.0198 \\
0.0715 \\
0.0166 \\
0.0362 \\
0.2398 \\
0.0094 \\
0.8783 \\
0.7971 \\
0.0209 \\
0.0000 \\
0.0000 \\
4.0181\end{array}$ & $\begin{array}{l}1.9209 \\
0.0139 \\
0.0791 \\
0.0380 \\
0.0327 \\
0.1710 \\
0.0057 \\
0.8662 \\
0.8694 \\
0.0194 \\
0.0000 \\
0.0000 \\
4.0163\end{array}$ & $\begin{array}{l}1.8737 \\
0.0206 \\
0.1263 \\
0.0323 \\
0.0736 \\
0.1340 \\
0.0066 \\
0.8647 \\
0.8841 \\
0.0208 \\
0.0000 \\
0.0000 \\
4.0368\end{array}$ & $\begin{array}{l}1.8661 \\
0.0344 \\
0.1339 \\
0.0427 \\
0.0440 \\
0.2281 \\
0.0066 \\
0.8169 \\
0.8276 \\
0.0216 \\
0.0000 \\
0.0000 \\
4.0220\end{array}$ & $\begin{array}{l}0.0 \\
0.0 \\
0.0 \\
0.0 \\
0.2 \\
0.0 \\
0.8 \\
0.8 \\
0.0 \\
0.0 \\
0.0\end{array}$ & $\begin{array}{l}0.0 \\
0.0 \\
0.0 \\
0.0 \\
0 . \\
0.0 \\
0.8 \\
0.0 \\
0.0 \\
0.0 \\
0.0\end{array}$ & $\begin{array}{l}0 . \\
0 . \\
0 . \\
0 . \\
0.0 \\
0 . \\
0 . \\
0 .\end{array}$ & & \\
\hline $\begin{array}{l}\text { Ac } \\
\text { Jd } \\
\text { FeCaTs } \\
\text { CrCaTs } \\
\text { Alcats }\end{array}$ & $\begin{array}{l}0.0138 \\
0.0115 \\
0.0000 \\
0.0000 \\
0.0177\end{array}$ & $\begin{array}{l}0.0185 \\
0.0000 \\
0.0215 \\
0.0000 \\
0.0339\end{array}$ & $\begin{array}{l}0.0209 \\
0.0000 \\
0.0328 \\
0.0000 \\
0.0280\end{array}$ & $\begin{array}{l}0.0000 \\
0.0304 \\
0.0000 \\
0.0184\end{array}$ & $\begin{array}{l}0.0194 \\
0.0000 \\
0.0094 \\
0.0000 \\
0.0411\end{array}$ & $\begin{array}{l}0.0260 \\
0.0000 \\
0.0104 \\
0.0000 \\
0.0406\end{array}$ & $\begin{array}{l}0.0166 \\
0.0000 \\
0.0081 \\
0.0000 \\
0.0287\end{array}$ & $\begin{array}{l}0.0209 \\
0.0000 \\
0.0153 \\
0.0000 \\
0.0166\end{array}$ & $\begin{array}{l}0.0000 \\
0.0133 \\
0.0000 \\
0.0380\end{array}$ & $\begin{array}{l}0.0 \\
0.0 \\
0.0 \\
0.0\end{array}$ & $\begin{array}{l}0.0 \\
0.0 \\
0.0 \\
0.0 \\
0.0\end{array}$ & $\begin{array}{l}0 . \\
0 . \\
0 . \\
0 .\end{array}$ & $\begin{array}{l}0.1 \\
0.1 \\
0 . \\
0 . \\
0 .\end{array}$ & & $\begin{array}{l}5 \\
0 \\
6 \\
0\end{array}$ & 0. \\
\hline $\begin{array}{l}\text { Wo } \\
\text { En } \\
\text { F8 } \\
\text { Mg\# }\end{array}$ & $\begin{array}{r}0.4165 \\
0.4309 \\
0.1526 \\
73.9\end{array}$ & $\begin{array}{r}0.4057 \\
0.4923 \\
0.1021 \\
82.8\end{array}$ & $\begin{array}{r}0.4001 \\
0.4857 \\
0.1142 \\
81.0\end{array}$ & $\begin{array}{r}0.4848 \\
0.1217 \\
79.9\end{array}$ & $\begin{array}{r}0.4784 \\
0.1058 \\
81.9\end{array}$ & $\begin{array}{r}0.3867 \\
0.4740 \\
0.1393 \\
77.3\end{array}$ & $\begin{array}{r}0.3936 \\
0.4831 \\
0.1233 \\
79.7\end{array}$ & $\begin{array}{r}0.3931 \\
0.4767 \\
0.1302 \\
78.6\end{array}$ & $\begin{array}{r}0.4854 \\
0.0958 \\
83.5\end{array}$ & $\begin{array}{r}0.5109 \\
0.0792 \\
86.6\end{array}$ & $\begin{array}{r}0.3920 \\
0.4753 \\
0.1327 \\
78.2\end{array}$ & $\begin{array}{r}0.4217 \\
0.4381 \\
0.1402 \\
75.8\end{array}$ & $\begin{array}{r}0.4173 \\
0.4425 \\
0.1402 \\
75.9\end{array}$ & $\begin{array}{r}0.4331 \\
0.1586 \\
73.2\end{array}$ & $\begin{array}{r}0.4007 \\
0.4719 \\
0.1274 \\
78.7\end{array}$ & $\begin{array}{r}0.4379 \\
0.1464 \\
74.9\end{array}$ \\
\hline
\end{tabular}




\begin{tabular}{|c|c|c|c|c|c|c|c|c|c|c|c|c|c|c|c|c|}
\hline $\begin{array}{l}\text { Strat\# } \\
\text { Field\# } \\
\text { Grain }\end{array}$ & $\begin{array}{r}s p-02 \\
s p-r s 2 \\
c 3 r \\
215\end{array}$ & $\begin{array}{r}s p-02 \\
s p-r 82 \\
c 4 g \\
216\end{array}$ & $\begin{array}{r}\text { sp-02 } \\
\text { sp-rs2 } \\
c 5 c \\
217\end{array}$ & $\begin{array}{r}s p-02 \\
s p-r s 2 \\
c 5 r \\
218\end{array}$ & $\begin{array}{r}A F-08 \\
85 \mathrm{cns08} \\
\mathrm{c1c} \\
163\end{array}$ & $\begin{array}{r}\text { AF-08 } \\
85 \mathrm{cns08} \\
\mathrm{cir} \\
164\end{array}$ & $\begin{array}{r}\text { AF-08 } \\
85 \mathrm{cns08} \\
\text { c2c } \\
165\end{array}$ & $\begin{array}{r}\text { AF-08 } \\
85 \mathrm{cns08} \\
\mathrm{c2r} \\
167\end{array}$ & $\begin{array}{r}A F-08 \\
85 \mathrm{cns08} \\
c 3 \mathrm{c} \\
168\end{array}$ & $\begin{array}{r}\text { AF-08 } \\
85 \mathrm{cns08} \\
\mathrm{c3r} \\
169\end{array}$ & $\begin{array}{r}\text { Af- } 08 \\
85 \text { cns08 } \\
\text { c4c } \\
170\end{array}$ & $\begin{array}{r}\text { AF-08 } \\
85 \mathrm{cns08} \\
c 4 r \\
171\end{array}$ & $\begin{array}{r}\text { Af }-08 \\
85 \mathrm{cns} 08 \\
\mathrm{c5c} \\
172\end{array}$ & $\begin{array}{r}\text { AF-08 } \\
85 \mathrm{cns08} \\
\text { c5r } \\
173\end{array}$ & $\begin{array}{r}A F-09 \\
85 \mathrm{cns} 09 \\
c 1 c \\
189\end{array}$ & $\begin{array}{r}\text { AF-09 } \\
85 \mathrm{crs} 09 \\
\mathrm{cIr} \\
190\end{array}$ \\
\hline $\begin{array}{l}\text { wtx } \\
\text { sio2 } \\
\text { Ti02 } \\
\text { At203 } \\
\text { FezO3 } \\
\text { FeO } \\
\text { MnO } \\
\text { MgO } \\
\text { CaO } \\
\text { Na2O } \\
\text { Cr203 } \\
\text { tot } \\
\text { FeO meas }\end{array}$ & $\begin{array}{r}52.52 \\
0.55 \\
1.82 \\
1.53 \\
7.61 \\
0.32 \\
15.00 \\
21.58 \\
0.36 \\
0.06 \\
101.34 \\
8.98\end{array}$ & $\begin{array}{r}52.00 \\
0.37 \\
1.71 \\
1.66 \\
8.46 \\
0.31 \\
14.54 \\
20.78 \\
0.42 \\
0.03 \\
100.29 \\
9.96\end{array}$ & $\begin{array}{r}53.46 \\
0.23 \\
0.80 \\
0.97 \\
7.61 \\
0.23 \\
15.24 \\
21.99 \\
0.30 \\
0.00 \\
100.83 \\
8.48\end{array}$ & $\begin{array}{r}53.11 \\
0.31 \\
1.27 \\
1.39 \\
7.81 \\
0.36 \\
15.05 \\
21.73 \\
0.34 \\
0.02 \\
101.39 \\
9.06\end{array}$ & $\begin{array}{r}52.96 \\
0.39 \\
1.48 \\
1.04 \\
8.68 \\
0.41 \\
14.59 \\
21.44 \\
0.34 \\
0.02 \\
101.35 \\
9.62\end{array}$ & $\begin{array}{r}53.01 \\
0.21 \\
0.97 \\
0.25 \\
10.01 \\
0.41 \\
14.23 \\
20.73 \\
0.29 \\
0.00 \\
100.12 \\
10.24\end{array}$ & $\begin{array}{r}52.44 \\
0.38 \\
1.68 \\
0.97 \\
8.39 \\
0.35 \\
14.53 \\
21.28 \\
0.34 \\
0.05 \\
100.42 \\
9.27\end{array}$ & $\begin{array}{r}52.27 \\
0.43 \\
1.54 \\
0.80 \\
9.10 \\
0.42 \\
14.24 \\
20.86 \\
0.35 \\
0.00 \\
100.01 \\
9.82\end{array}$ & $\begin{array}{r}52.59 \\
0.25 \\
1.02 \\
1.37 \\
8.41 \\
0.32 \\
14.59 \\
21.43 \\
0.33 \\
0.05 \\
100.37 \\
9.65\end{array}$ & $\begin{array}{r}52.32 \\
0.26 \\
1.18 \\
1.05 \\
8.33 \\
0.36 \\
14.34 \\
21.31 \\
0.37 \\
0.01 \\
9.54 \\
9.28\end{array}$ & $\begin{array}{r}52.46 \\
0.22 \\
1.04 \\
1.05 \\
9.03 \\
0.35 \\
13.82 \\
21.74 \\
0.33 \\
0.00 \\
100.05 \\
9.98\end{array}$ & $\begin{array}{r}51.91 \\
0.32 \\
0.87 \\
1.08 \\
8.77 \\
0.30 \\
13.91 \\
21.64 \\
0.27 \\
0.01 \\
99.08 \\
9.74\end{array}$ & $\begin{array}{r}51.88 \\
0.48 \\
1.86 \\
1.19 \\
8.25 \\
0.30 \\
14.36 \\
21.29 \\
0.34 \\
0.02 \\
99.97 \\
9.32\end{array}$ & $\begin{array}{r}52.48 \\
0.30 \\
0.91 \\
1.45 \\
8.99 \\
0.35 \\
16.49 \\
21.02 \\
0.34 \\
0.03 \\
100.36 \\
10.29\end{array}$ & $\begin{array}{r}52.43 \\
0.59 \\
2.02 \\
0.91 \\
8.25 \\
0.27 \\
14.96 \\
20.83 \\
0.38 \\
0.04 \\
100.68 \\
9.07\end{array}$ & $\begin{array}{r}52.33 \\
0.48 \\
1.48 \\
1.17 \\
9.23 \\
0.38 \\
14.59 \\
20.49 \\
0.36 \\
0.05 \\
100.56 \\
10.28\end{array}$ \\
\hline $\begin{array}{l}\text { atoms } / 6 \\
\text { Si } \\
\text { Ti } \\
\text { Ai t } \\
\text { At o } \\
\text { Fe3+ } \\
\text { Fe2+ } \\
\text { Mn } \\
\mathrm{Mg} \\
\mathrm{Ca} \\
\mathrm{Ma} \\
\mathrm{Mi} \\
\mathrm{Cr} \\
\text { tot }\end{array}$ & $\begin{array}{l}1.9360 \\
0.0152 \\
0.0640 \\
0.0151 \\
0.0423 \\
0.2345 \\
0.0100 \\
0.8241 \\
0.8524 \\
0.0257 \\
0.0000 \\
0.0017 \\
4.0212\end{array}$ & $\begin{array}{l}1.9433 \\
0.0104 \\
0.0567 \\
0.0186 \\
0.0468 \\
0.2645 \\
0.0098 \\
0.8098 \\
0.8321 \\
0.0304 \\
0.0000 \\
0.0009 \\
4.0234\end{array}$ & $\begin{array}{l}1.9735 \\
0.0064 \\
0.0265 \\
0.0083 \\
0.0269 \\
0.2349 \\
0.0072 \\
0.8384 \\
0.8698 \\
0.0215 \\
0.0000 \\
0.0000\end{array}$ & $\begin{array}{l}1.9564 \\
0.0086 \\
0.0436 \\
0.0116 \\
0.0386 \\
0.2405 \\
0.0112 \\
0.8262 \\
0.8577 \\
0.0243 \\
0.0000 \\
0.0006\end{array}$ & $\begin{array}{l}0.0108 \\
0.0456 \\
0.0188 \\
0.0289 \\
0.2680 \\
0.0128 \\
0.8024 \\
0.8478 \\
0.0243 \\
0.0000 \\
0.0006 \\
4.0145\end{array}$ & $\begin{array}{l}0.0059 \\
0.0203 \\
0.0224 \\
0.0072 \\
0.3127 \\
0.0130 \\
0.7920 \\
0.8295 \\
0.0210 \\
0.0000 \\
0.0000 \\
4.0036\end{array}$ & $\begin{array}{l}0.0106 \\
0.0496 \\
0.0241 \\
0.0272 \\
0.2611 \\
0.0110 \\
0.8054 \\
0.8481 \\
0.0245 \\
0.0000 \\
0.0015\end{array}$ & $\begin{array}{l}0.0 \\
0.0 \\
0.0 \\
0.0 \\
0.2 \\
0.0 \\
0.7 \\
0.8 \\
0.0 \\
0.0 \\
0.0 \\
4.0\end{array}$ & $\begin{array}{l}0.0 \\
0.0 \\
0.0 \\
0.0 \\
0.8 \\
0.0 \\
0.8 \\
0.8 \\
0.0 \\
0.0 \\
0.0\end{array}$ & $\begin{array}{l}0.0073 \\
0.0350 \\
0.0172 \\
0.0298 \\
0.2617 \\
0.0115 \\
0.8026 \\
0.8576 \\
0.0269 \\
0.0000 \\
0.0003 \\
4.0149\end{array}$ & $\begin{array}{l}0.0 \\
0.0 \\
0.0 \\
0.0 \\
0.8 \\
0.0 \\
0.7 \\
0.8 \\
0.0 \\
0.0 \\
0.0\end{array}$ & $\begin{array}{l}0 . \\
0 . \\
0 . \\
0 . \\
0 . \\
0 . \\
0 . \\
0 . \\
0 . \\
0 . \\
0 .\end{array}$ & & & & $\begin{array}{l}0 \\
0 \\
0 \\
0 \\
0 \\
0 \\
0 \\
0 \\
0\end{array}$ \\
\hline $\begin{array}{l}\text { Ac } \\
\text { Jd } \\
\text { FeCaTs } \\
\text { CrCaTs } \\
\text { AlCaTs }\end{array}$ & $\begin{array}{l}0.0257 \\
0.0000 \\
0.0166 \\
0.0017 \\
0.0151\end{array}$ & $\begin{array}{l}0.0304 \\
0.0000 \\
0.0164 \\
0.0009 \\
0.0186\end{array}$ & $\begin{array}{l}0.0000 \\
0.0054 \\
0.0000 \\
0.0083\end{array}$ & $\begin{array}{l}0.0000 \\
0.0143 \\
0.0006 \\
0.0116\end{array}$ & $\begin{array}{l}0.0 \\
0.0 \\
0.0 \\
0.0\end{array}$ & $\begin{array}{l}0.0138 \\
0.0000 \\
0.0000 \\
0.0085\end{array}$ & $\begin{array}{l}0.0000 \\
0.0027 \\
0.0015 \\
0.0241\end{array}$ & $\begin{array}{l}0.0 \\
0.0 \\
0.0 \\
0.0 \\
0.0\end{array}$ & $\begin{array}{l}0.0 \\
0.0 \\
0.0 \\
0.0 \\
0.0\end{array}$ & $\begin{array}{l}0.0 \\
0.0 \\
0.0 \\
0.0\end{array}$ & & & & & & \\
\hline $\begin{array}{l}\text { Wo } \\
\text { En } \\
F_{8} \\
M g \#\end{array}$ & $\begin{array}{r}0.4223 \\
0.4497 \\
0.1280 \\
77.8\end{array}$ & $\begin{array}{l}0.4133 \\
0.4422 \\
0.1444 \\
75.4\end{array}$ & $\begin{array}{r}0.4384 \\
0.1228 \\
78.1\end{array}$ & $\begin{array}{r}0.4278 \\
0.4432 \\
0.1290 \\
77.5\end{array}$ & $\begin{array}{r}0.4241 \\
0.4317 \\
0.1442 \\
75.0\end{array}$ & $\begin{array}{r}0.4201 \\
0.1658 \\
71.7\end{array}$ & $\begin{array}{r}0.4222 \\
0.4364 \\
0.1415 \\
75.5\end{array}$ & $\begin{array}{r}0.4191 \\
0.4276 \\
0.1533 \\
73.6\end{array}$ & $\begin{array}{r}0.4286 \\
0.4317 \\
0.1397 \\
75.5\end{array}$ & $\begin{array}{r}0.4321 \\
0.4283 \\
0.1396 \\
75.4\end{array}$ & $\begin{array}{l}0.43 \\
0.41 \\
0.15 \\
73\end{array}$ & $\begin{array}{l}0.4 \\
0.4 \\
0.1\end{array}$ & $\begin{array}{l}0.4 \\
0.4 \\
0.1\end{array}$ & $\begin{array}{l}0 . \\
0 . \\
0 .\end{array}$ & $\begin{array}{l}0 . \\
0 . \\
0 .\end{array}$ & 0 \\
\hline
\end{tabular}




\begin{tabular}{|c|c|c|c|c|c|c|c|c|c|c|c|c|c|c|c|c|}
\hline $\begin{array}{l}\text { Strat\# } \\
\text { Field\# } \\
\text { Grain } \\
\text { Anal\# }\end{array}$ & $\begin{array}{r}\text { AF-09 } \\
85 \mathrm{cns09} \\
\mathrm{c2c} \\
191\end{array}$ & $\begin{array}{r}\text { AF-09 } \\
85 \mathrm{cns} 09 \\
\mathrm{c2r} \\
192\end{array}$ & $\begin{array}{r}A F-09 \\
85 \mathrm{cns09} \\
c 3 c \\
193\end{array}$ & $\begin{array}{r}A F-09 \\
85 \text { cns09 } \\
\text { c3r } \\
194\end{array}$ & $\begin{array}{r}\text { AF-09 } \\
85 \text { cns09 } \\
\text { c4c } \\
195\end{array}$ & $\begin{array}{r}\text { AF-09 } \\
85 \mathrm{cns} 09 \\
\mathrm{c4r} \\
196\end{array}$ & $\begin{array}{r}A F-09 \\
85 \mathrm{cns} 09 \\
\text { C5c } \\
197\end{array}$ & $\begin{array}{r}A F-09 \\
85 \mathrm{cns} 09 \\
c 5 r \\
198\end{array}$ & $\begin{array}{r}\text { AF-09 } \\
85 \mathrm{cns} 09 \\
\text { c6c=04j } \\
207\end{array}$ & $\begin{array}{r}P F-38 \\
85 \mathrm{cns} 38 \\
c 1 c \\
141\end{array}$ & $\begin{array}{r}\text { PF-38 } \\
85 \mathrm{cns} 38 \\
c 1 r \\
142\end{array}$ & $\begin{array}{r}P F-38 \\
85 \mathrm{cns} 38 \\
c 2 c \\
145\end{array}$ & $\begin{array}{r}P F-38 \\
85 \mathrm{cns} 38 \\
\mathrm{c2r} \\
147\end{array}$ & $\begin{array}{r}p F-38 \\
85 \mathrm{cns} 38 \\
\mathrm{c3g} \\
150\end{array}$ & $\begin{array}{r}\text { PF-38 } \\
85 \mathrm{cns} 38 \\
c 4 c \\
151\end{array}$ & $\begin{array}{r}P F-38 \\
85 \text { ens } 38 \\
c 4 r \\
152\end{array}$ \\
\hline $\begin{array}{l}\text { wtY } \\
\text { siog } \\
\text { Ti02 } \\
\text { it203 } \\
\text { Fe203 } \\
\text { Feo } \\
\text { Mno } \\
\text { Mgo } \\
\text { Ce0 } \\
\text { Na20 } \\
\text { Cr203 } \\
\text { tot } \\
\text { Feo meas }\end{array}$ & $\begin{array}{r}53.24 \\
0.20 \\
1.08 \\
1.07 \\
8.83 \\
0.35 \\
14.66 \\
21.49 \\
0.32 \\
0.04 \\
101.28 \\
9.79\end{array}$ & $\begin{array}{r}52.30 \\
0.45 \\
1.74 \\
1.79 \\
8.59 \\
0.30 \\
14.73 \\
20.81 \\
0.42 \\
0.05 \\
101.18 \\
10.20\end{array}$ & $\begin{array}{r}52.12 \\
0.47 \\
1.61 \\
1.96 \\
7.77 \\
0.39 \\
14.77 \\
21.37 \\
0.38 \\
0.01 \\
100.85 \\
9.53\end{array}$ & $\begin{array}{r}52.02 \\
0.39 \\
1.70 \\
1.14 \\
9.02 \\
0.35 \\
14.30 \\
20.75 \\
0.35 \\
0.00 \\
100.02 \\
10.05\end{array}$ & $\begin{array}{r}52.95 \\
0.35 \\
1.39 \\
0.47 \\
9.19 \\
0.41 \\
14.54 \\
20.91 \\
0.33 \\
0.00 \\
100.54 \\
9.61\end{array}$ & $\begin{array}{r}52.59 \\
0.26 \\
1.38 \\
1.44 \\
8.59 \\
0.34 \\
14.82 \\
20.81 \\
0.38 \\
0.02 \\
100.62 \\
9.88\end{array}$ & $\begin{array}{r}52.07 \\
0.43 \\
1.77 \\
1.56 \\
8.64 \\
0.31 \\
14.50 \\
20.91 \\
0.38 \\
0.00 \\
100.58 \\
10.05\end{array}$ & $\begin{array}{r}52.82 \\
0.27 \\
0.98 \\
0.00 \\
8.70 \\
0.49 \\
14.56 \\
19.11 \\
0.37 \\
0.02 \\
97.32 \\
8.70\end{array}$ & $\begin{array}{r}53.38 \\
0.42 \\
1.24 \\
0.58 \\
8.79 \\
0.36 \\
15.52 \\
20.32 \\
0.35 \\
0.06 \\
101.02 \\
9.31\end{array}$ & $\begin{array}{r}49.73 \\
0.90 \\
2.85 \\
1.47 \\
8.34 \\
0.24 \\
14.15 \\
19.70 \\
0.41 \\
\text { na } \\
97.79 \\
9.66\end{array}$ & $\begin{array}{r}52.35 \\
0.43 \\
2.05 \\
1.08 \\
8.60 \\
0.28 \\
14.85 \\
20.68 \\
0.35 \\
\text { na } \\
100.67 \\
9.57\end{array}$ & $\begin{array}{r}51.45 \\
0.51 \\
3.07 \\
1.28 \\
8.45 \\
0.25 \\
15.23 \\
19.36 \\
0.41 \\
\text { na } \\
100.01 \\
9.60\end{array}$ & $\begin{array}{r}51.71 \\
0.61 \\
1.88 \\
1.45 \\
9.46 \\
0.25 \\
14.63 \\
20.18 \\
0.30 \\
\text { na } \\
100.48 \\
10.77\end{array}$ & $\begin{array}{r}51.93 \\
0.36 \\
1.84 \\
1.32 \\
7.80 \\
0.27 \\
14.63 \\
21.37 \\
0.32 \\
. n 9 \\
99.84 \\
8.99\end{array}$ & $\begin{array}{r}50.39 \\
0.66 \\
2.94 \\
2.13 \\
7.81 \\
0.25 \\
15.30 \\
19.11 \\
0.43 \\
\mathrm{ng} \\
99.02 \\
9.73\end{array}$ & $\begin{array}{r}51.62 \\
0.53 \\
2.29 \\
2.08 \\
8.14 \\
0.24 \\
14.66 \\
21.11 \\
0.34 \\
\text { na } \\
101.01 \\
10.01\end{array}$ \\
\hline $\begin{array}{l}\text { atoms/6 } \\
\text { Si } \\
\text { Ti } \\
\text { Al t } \\
\text { Al o } \\
\text { Fe3+ } \\
\text { Fe2t } \\
\text { Mn } \\
\mathrm{Mg} \\
\mathrm{Ca} \\
\mathrm{Na} \\
\mathrm{Ni} \\
\mathrm{Cr} \\
\text { tot }\end{array}$ & $\begin{array}{l}1.9669 \\
0.0056 \\
0.0331 \\
0.0139 \\
0.0298 \\
0.2727 \\
0.0110 \\
0.8072 \\
0.8507 \\
0.0229 \\
0.0000 \\
0.0012 \\
4.0149\end{array}$ & $\begin{array}{l}1.9388 \\
0.0125 \\
0.0612 \\
0.0148 \\
0.0501 \\
0.2662 \\
0.0094 \\
0.8138 \\
0.8266 \\
0.0302 \\
0.0000 \\
0.0015 \\
4.0250\end{array}$ & $\begin{array}{l}1.9377 \\
0.0131 \\
0.0623 \\
0.0083 \\
0.0548 \\
0.2415 \\
0.0123 \\
0.8184 \\
0.8513 \\
0.0274 \\
0.0000 \\
0.0003 \\
4.0274\end{array}$ & $\begin{array}{l}1.9481 \\
0.0110 \\
0.0519 \\
0.0231 \\
0.0322 \\
0.2825 \\
0.0111 \\
0.7981 \\
0.8326 \\
0.0254 \\
0.0000 \\
0.0000 \\
4.0161\end{array}$ & $\begin{array}{l}1.9652 \\
0.0098 \\
0.0348 \\
0.0260 \\
0.0130 \\
0.2853 \\
0.0129 \\
0.8042 \\
0.8315 \\
0.0237 \\
0.0000 \\
0.0000 \\
4.0065\end{array}$ & $\begin{array}{l}1.9558 \\
0.0073 \\
0.0442 \\
0.0163 \\
0.0403 \\
0.2670 \\
0.0107 \\
0.8214 \\
0.8292 \\
0.0274 \\
0.0000 \\
0.0006 \\
4.0201\end{array}$ & $\begin{array}{l}1.9409 \\
0.0121 \\
0.0591 \\
0.0187 \\
0.0438 \\
0.2695 \\
0.0098 \\
0.8055 \\
0.8351 \\
0.0275 \\
0.0000 \\
0.0000 \\
4.0219\end{array}$ & $\begin{array}{r}2.0055 \\
0.0077 \\
-0.0055 \\
0.0493 \\
0.0000 \\
0.2763 \\
0.0158 \\
0.8239 \\
0.7774 \\
0.0272 \\
0.0000 \\
0.0006 \\
3.9782\end{array}$ & $\begin{array}{l}1.9650 \\
0.0116 \\
0.0350 \\
0.0189 \\
0.0161 \\
0.2705 \\
0.0112 \\
0.8515 \\
0.8015 \\
0.0250 \\
0.0000 \\
0.0017 \\
4.0080\end{array}$ & $\begin{array}{l}1.9038 \\
0.0259 \\
0.0962 \\
0.0324 \\
0.0424 \\
0.2669 \\
0.0078 \\
0.8073 \\
0.8081 \\
0.0304 \\
0.0000 \\
0.0000\end{array}$ & $\begin{array}{l}1.9408 \\
0.0120 \\
0.0592 \\
0.0304 \\
0.0300 \\
0.2667 \\
0.0088 \\
0.8205 \\
0.8215 \\
0.0252 \\
0.0000 \\
0.0000 \\
4.0150\end{array}$ & $\begin{array}{l}0.0 \\
0.0 \\
0.0 \\
0.0 \\
0.2 \\
0.0 \\
0.8 \\
0.7 \\
0.0 \\
0.0 \\
0.0\end{array}$ & $\begin{array}{l}0.0 \\
0.0 \\
0.0 \\
0.0 \\
0.2 \\
0.0 \\
0.8 \\
0.8 \\
0.0 \\
0.0 \\
0.0\end{array}$ & $\begin{array}{l}1.5 \\
0.0 \\
0.0 \\
0.0 \\
0.0 \\
0.0 \\
0.0 \\
0.8 \\
0.8 \\
0.0 \\
0 . \\
0.0\end{array}$ & $\begin{array}{l}3 \\
7 \\
17 \\
1 \\
6 \\
4 \\
0 \\
4 \\
6 \\
15 \\
0 \\
0 \\
0 \\
3\end{array}$ & $\begin{array}{l}1 . \\
0 . \\
0 . \\
0 . \\
0 . \\
0 . \\
0 . \\
0 . \\
0 . \\
0 . \\
0 . \\
0 .\end{array}$ \\
\hline $\begin{array}{l}\text { Ac } \\
\text { Jd } \\
\text { FeCaTs } \\
\text { CrCaTs } \\
\text { AlCaTs }\end{array}$ & $\begin{array}{l}0.0229 \\
0.0000 \\
0.0069 \\
0.0012 \\
0.0139\end{array}$ & $\begin{array}{l}0.0302 \\
0.0000 \\
0.0199 \\
0.0015 \\
0.0148\end{array}$ & $\begin{array}{l}0.0274 \\
0.0000 \\
0.0274 \\
0.0003 \\
0.0083\end{array}$ & $\begin{array}{l}0.0254 \\
0.0000 \\
0.0068 \\
0.0000 \\
0.0231\end{array}$ & $\begin{array}{l}0.0130 \\
0.0107 \\
0.0000 \\
0.0000 \\
0.0153\end{array}$ & $\begin{array}{l}0.0274 \\
0.0000 \\
0.0129 \\
0.0006 \\
0.0163\end{array}$ & $\begin{array}{l}0.0275 \\
0.0000 \\
0.0163 \\
0.0000 \\
0.0187\end{array}$ & $\begin{array}{l}0.0000 \\
0.0272 \\
0.0000 \\
0.0006 \\
0.0221\end{array}$ & $\begin{array}{l}0.0 \\
0.0 \\
0.0 \\
0.0 \\
0.0\end{array}$ & $\begin{array}{l}0.0 \\
0.0 \\
0.0 \\
0.0 \\
0.0\end{array}$ & $\begin{array}{l}0.0 \\
0.0 \\
0.0 \\
0.0 \\
0.0\end{array}$ & $\begin{array}{l}0.0 \\
0.0 \\
0.0 \\
0.0 \\
0.0\end{array}$ & $\begin{array}{l}0 . \\
0 . \\
0 . \\
0 . \\
0 .\end{array}$ & $\begin{array}{l}0 . \\
0 . \\
0 . \\
0 .\end{array}$ & $\begin{array}{l}5 \\
10 \\
17 \\
6\end{array}$ & $\begin{array}{l}0 . \\
0 . \\
0 .\end{array}$ \\
\hline $\begin{array}{l}\text { Wo } \\
\text { En } \\
\text { Fs } \\
\text { Mg\# }\end{array}$ & $\begin{array}{r}0.4258 \\
0.4292 \\
0.1450 \\
74.7\end{array}$ & $\begin{array}{r}0.4103 \\
0.4443 \\
0.1453 \\
75.4\end{array}$ & $\begin{array}{r}0.4214 \\
0.4468 \\
0.1319 \\
77.2\end{array}$ & $\begin{array}{l}0.4140 \\
0.4328 \\
0.1532 \\
73.9\end{array}$ & $\begin{array}{r}0.4146 \\
0.4321 \\
0.1533 \\
73.8\end{array}$ & $\begin{array}{r}0.4135 \\
0.4426 \\
0.1439 \\
75.5\end{array}$ & $\begin{array}{r}0.4138 \\
0.4392 \\
0.1470 \\
74.9\end{array}$ & $\begin{array}{l}0.37 \\
0.4 \\
0.15 \\
7\end{array}$ & $\begin{array}{r}0.4029 \\
0.4531 \\
0.1440 \\
75.9\end{array}$ & $\begin{array}{r}0.3971 \\
0.4531 \\
0.1498 \\
75.2\end{array}$ & $\begin{array}{r}0.4057 \\
0.4485 \\
0.1458 \\
75.5\end{array}$ & $\begin{array}{r}0.3728 \\
0.4782 \\
0.1489 \\
76.3\end{array}$ & $\begin{array}{r}0.397 \\
0.4418 \\
0.1603 \\
73 .\end{array}$ & $\begin{array}{l}1 \\
5 \\
3 \\
0\end{array}$ & $\begin{array}{r}0.4 \\
0.1\end{array}$ & $\begin{array}{r}0.45 \\
0.12 \\
7\end{array}$ \\
\hline
\end{tabular}




\begin{tabular}{|c|c|c|c|c|c|c|c|c|c|c|c|c|c|c|c|c|}
\hline & $\begin{array}{r}\text { F-38 } \\
\text { ins38 } \\
c 5 c \\
153\end{array}$ & $\begin{array}{r}\text { PF-38 } \\
\text { sens38 } \\
\text { c5r } \\
154\end{array}$ & $\begin{array}{l}\text { F. }-38 \\
\text { :ns } \\
=058 \\
144 \\
144\end{array}$ & $\begin{array}{r}\text { PF-38 } \\
85 \text { cns38 } \\
\text { P.c6c } \\
148\end{array}$ & $\begin{array}{r}\text { PCP-B01 } \\
85 \text { cns33 } \\
\text { c1c } \\
278\end{array}$ & $\begin{array}{r}p-801 \\
\text { cns33 } \\
\text { c1r } \\
279\end{array}$ & $\begin{array}{r}\text { PCP-BO1 } \\
85 \text { Cns33 } \\
\text { C2C } \\
280\end{array}$ & $\begin{array}{l}801 \\
533 \\
22 r\end{array}$ & $\begin{array}{r}P c P-801 \\
85 c n s 33 \\
\text { c3c } \\
287\end{array}$ & $\begin{array}{r}\text { PCP-BO1 } \\
85 \text { ens33 } \\
C 3 r\end{array}$ & $\begin{array}{l}3 \\
2 \\
c\end{array}$ & $\begin{array}{l}03 \\
52 \\
1 r\end{array}$ & & & & \\
\hline 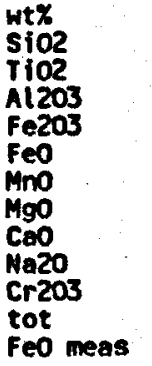 & $\begin{array}{r}0.68 \\
2.67 \\
2.04 \\
7.58 \\
0.25 \\
14.80 \\
20.51 \\
0.38 \\
99 \\
99.68 \\
9.41\end{array}$ & $\begin{array}{r}51.14 \\
0.44 \\
2.06 \\
2.18 \\
7.68 \\
0.29 \\
14.71 \\
20.82 \\
0.36 \\
\text { no } \\
99.68 \\
9.64\end{array}$ & $\begin{array}{r}52.11 \\
0.48 \\
1.91 \\
1.52 \\
8.14 \\
0.32 \\
15.56 \\
20.02 \\
0.34 \\
100 \\
100.40 \\
9.51\end{array}$ & $\begin{array}{r}1.56 \\
0.56 \\
1.92 \\
1.33 \\
9.19 \\
0.24 \\
14.48 \\
20.00 \\
0.32 \\
99.26 \\
10.36 \\
10.39\end{array}$ & $\begin{array}{r}50.74 \\
0.75 \\
4.02 \\
1.23 \\
6.99 \\
0.23 \\
14.82 \\
20.76 \\
0.36 \\
0.13 \\
100.03 \\
8.10\end{array}$ & $\begin{array}{r}52.67 \\
0.50 \\
2.55 \\
0.00 \\
7.59 \\
0.17 \\
15.92 \\
20.30 \\
0.27 \\
0.09\end{array}$ & $\begin{array}{r}50.41 \\
0.90 \\
4.41 \\
1.08 \\
7.32 \\
0.16 \\
14.52 \\
20.76 \\
0.35 \\
0.13 \\
100.04 \\
8.29\end{array}$ & $\begin{array}{r}51.39 \\
0.53 \\
2.55 \\
1.57 \\
8.05 \\
0.23 \\
15.02 \\
20.37 \\
0.32 \\
0.05\end{array}$ & $\begin{array}{r}49.59 \\
1.00 \\
5.16 \\
1.49 \\
7.23 \\
0.15 \\
14.21 \\
20.53 \\
0.40 \\
0.13 \\
99.89 \\
8.57\end{array}$ & $\begin{array}{r}51.00 \\
0.71 \\
3.29 \\
1.35 \\
7.69 \\
0.20 \\
14.76 \\
20.54 \\
0.37 \\
0.04\end{array}$ & $\begin{array}{r}51.60 \\
0.66 \\
4.20 \\
0.48 \\
5.82 \\
0.18 \\
15.86 \\
20.96 \\
0.30 \\
\text { na }\end{array}$ & $\begin{array}{r}50.67 \\
0.78 \\
4.84 \\
0.68 \\
5.91 \\
0.19 \\
15.63 \\
20.34 \\
0.34 \\
\text { na }\end{array}$ & $\begin{array}{r}0.43 \\
2.32 \\
0.31 \\
7.28 \\
0.24 \\
16.13 \\
20.23 \\
0.31 \\
n 9\end{array}$ & $\begin{array}{r}51.80 \\
0.69 \\
2.41 \\
0.84 \\
8.55 \\
0.35 \\
15.13 \\
20.19 \\
0.27 \\
\text { na }\end{array}$ & $\begin{array}{l}0 \\
0 \\
0\end{array}$ & $\begin{array}{r}0.46 \\
3.16 \\
1.08 \\
5.10 \\
0.22 \\
16.51 \\
21.03 \\
0.27 \\
09\end{array}$ \\
\hline $3+$ & $\begin{array}{l}0.0192 \\
0.0932 \\
0.0250 \\
0.0553 \\
0.2380 \\
0.0080 \\
0.8282 \\
0.8252 \\
0.0277 \\
0.0000 \\
0.000\end{array}$ & $\begin{array}{l}0.0125 \\
0.0759 \\
0.0155 \\
0.0618 \\
0.2415 \\
0.0092 \\
0.8248 \\
0.8393 \\
0.0263 \\
0.0000\end{array}$ & $\begin{array}{l}0.0642 \\
0.0194 \\
0.0424 \\
0.2530 \\
0.0101 \\
0.08615 \\
0.7969 \\
0.0245 \\
0.0245\end{array}$ & $\begin{array}{l}0159 \\
0658 \\
0196 \\
0378 \\
2903 \\
0077 \\
8149 \\
8092 \\
0234 \\
0000\end{array}$ & & & & & & & & & & & & \\
\hline 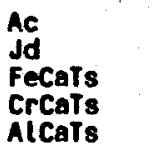 & $\begin{array}{l}0 \\
0 \\
0 \\
0\end{array}$ & $\begin{array}{l}0 \\
0 \\
0 \\
0\end{array}$ & & $\begin{array}{l}0 \\
0 \\
0\end{array}$ & & & & & & & & & & & & \\
\hline En & 0.46 & 0 & 7.3 & 0.44 & 0 & 78.9 & 78.0 & & & & & & & & & \\
\hline
\end{tabular}




\begin{tabular}{|c|c|c|c|c|c|c|c|c|c|c|c|c|c|c|c|c|}
\hline $\begin{array}{l}\text { Strat\# } \\
\text { Field\#\# } \\
\text { Grain } \\
\text { Anal\# }\end{array}$ & $\begin{array}{r}\text { PCP-A03 } \\
85 \mathrm{cns52} \\
\mathrm{C4C} \\
75\end{array}$ & $\begin{array}{r}P C P-A 03 \\
85 \text { cns52 } \\
C 4 r \\
76\end{array}$ & $\begin{array}{r}P C P-103 \\
85 \mathrm{cns52} \\
\mathrm{C5c} \\
77\end{array}$ & $\begin{array}{r}P C P-103 \\
85 \mathrm{cns52} \\
\mathrm{C5r} \\
78\end{array}$ & $\begin{array}{r}P C P-A 05 \\
85 \mathrm{cns} 50 \\
91 . C 3 c \\
95\end{array}$ & $\begin{array}{r}\text { PCP-A05 } \\
85 \text { Cns50 } \\
\text { P2.c1c } \\
114\end{array}$ & $\begin{array}{r}P C P-A 05 \\
85 \mathrm{cns50} \\
\text { P2.c1r } \\
115\end{array}$ & $\begin{array}{r}\text { PCP- } 105 \\
85 c n s 50 \\
\text { P2.c2c } \\
118\end{array}$ & $\begin{array}{r}\text { PCP-A05 } \\
85 \text { Cns50 } \\
\text { P2. C2r } \\
119\end{array}$ & $\begin{array}{r}\mathrm{cP}-07 \\
85 \mathrm{cns} 60 \\
\mathrm{c1c} \\
124\end{array}$ & $\begin{array}{r}\text { CP-07 } \\
85 \mathrm{cns} 60 \\
\mathrm{c1r} \\
125\end{array}$ & $\begin{array}{r}c P-07 \\
85 \mathrm{cns} 60 \\
c 2 c \\
126\end{array}$ & $\begin{array}{r}c P-07 \\
85 \mathrm{cns} 60 \\
c 2 r \\
127\end{array}$ & $\begin{array}{r}c P-07 \\
85 \mathrm{cns} 60 \\
c 3 c \\
128\end{array}$ & $\begin{array}{r}\text { CP- } 07 \\
85 \text { cns60 } \\
\text { c3r } \\
129\end{array}$ & $\begin{array}{r}\text { CP-07 } \\
85 \text { cns60 } \\
\text { c4c } \\
130\end{array}$ \\
\hline $\begin{array}{l}\text { HtX } \\
\text { SiO2 } \\
\text { Tio2 } \\
\text { Ali203 } \\
\text { Fe203 } \\
\text { FeO } \\
\text { MnO } \\
\text { MgO } \\
\text { CaO } \\
\text { No20 } \\
\text { Cr203 } \\
\text { tot } \\
\text { FeO meas }\end{array}$ & $\begin{array}{r}50.73 \\
0.74 \\
3.21 \\
1.50 \\
7.06 \\
0.22 \\
14.87 \\
20.58 \\
0.40 \\
99.79 \\
9.31 \\
8.41\end{array}$ & $\begin{array}{r}51.97 \\
0.64 \\
1.85 \\
0.81 \\
9.19 \\
0.30 \\
15.04 \\
19.75 \\
0.32 \\
\text { na } \\
99.87 \\
9.92\end{array}$ & $\begin{array}{r}52.66 \\
0.25 \\
2.40 \\
0.37 \\
6.42 \\
0.20 \\
16.53 \\
20.42 \\
0.24 \\
99 \\
99.50 \\
6.76\end{array}$ & $\begin{array}{r}51.19 \\
0.63 \\
4.06 \\
0.88 \\
5.45 \\
0.13 \\
15.80 \\
21.07 \\
0.31 \\
99 \\
99.52 \\
6.24\end{array}$ & $\begin{array}{r}49.79 \\
1.11 \\
5.46 \\
1.40 \\
7.63 \\
0.16 \\
14.38 \\
20.14 \\
0.42 \\
100 \\
10.49 \\
8.89\end{array}$ & $\begin{array}{r}50.90 \\
0.99 \\
3.27 \\
1.55 \\
8.74 \\
0.24 \\
15.13 \\
19.46 \\
0.34 \\
100 \\
100.62 \\
10.13\end{array}$ & $\begin{array}{r}50.75 \\
0.81 \\
3.56 \\
1.75 \\
7.03 \\
0.25 \\
15 \\
15.12 \\
20.49 \\
0.37 \\
100 \\
10.14 \\
8.61\end{array}$ & $\begin{array}{r}50.30 \\
0.66 \\
4.05 \\
1.91 \\
5.28 \\
0.16 \\
15.55 \\
21.04 \\
0.32 \\
99.27 \\
9.27 \\
7.00\end{array}$ & $\begin{array}{r}50.11 \\
0.65 \\
3.74 \\
2.26 \\
6.62 \\
0.19 \\
15.04 \\
20.48 \\
0.36 \\
\text { na } \\
99.45 \\
8.65\end{array}$ & $\begin{array}{r}50.77 \\
0.81 \\
4.59 \\
0.84 \\
5.78 \\
0.20 \\
15.28 \\
21.02 \\
0.36 \\
99.68 \\
9.65 \\
6.54\end{array}$ & $\begin{array}{r}53.06 \\
0.37 \\
2.53 \\
0.44 \\
6.07 \\
0.22 \\
177.07 \\
20.34 \\
0.26 \\
100.36 \\
6.47\end{array}$ & $\begin{array}{r}51.00 \\
0.75 \\
4.86 \\
0.76 \\
6.44 \\
0.20 \\
15.79 \\
19.94 \\
0.36 \\
100 \\
10.11 \\
7.13\end{array}$ & $\begin{array}{r}53.00 \\
0.38 \\
2.55 \\
0.18 \\
6.42 \\
0.20 \\
16.67 \\
20.39 \\
0.29 \\
100.08 \\
10.08 \\
6.58\end{array}$ & $\begin{array}{r}51.20 \\
0.79 \\
4.78 \\
0.58 \\
6.33 \\
0.20 \\
15.61 \\
20.43 \\
0.36 \\
100 \text { na } \\
10.28 \\
6.85\end{array}$ & $\begin{array}{r}53.23 \\
0.35 \\
2.64 \\
0.09 \\
6.41 \\
0.17 \\
16.94 \\
20.32 \\
0.26 \\
100.41 \\
6.49\end{array}$ & $\begin{array}{r}52.61 \\
0.48 \\
2.68 \\
0.13 \\
7.88 \\
0.16 \\
15.54 \\
20.61 \\
0.27 \\
100 \\
10.36 \\
8.00\end{array}$ \\
\hline 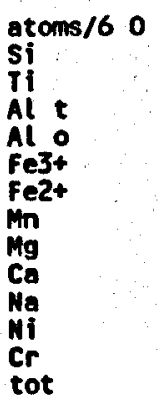 & $\begin{array}{l}1.9015 \\
0.0209 \\
0.0985 \\
0.0434 \\
0.0424 \\
0.2212 \\
0.0070 \\
0.8307 \\
0.8266 \\
0.0291 \\
0.0000 \\
0.0000 \\
4.0212\end{array}$ & $\begin{array}{l}1.9415 \\
0.0180 \\
0.0585 \\
0.0229 \\
0.0228 \\
0.2871 \\
0.0095 \\
0.8373 \\
0.7906 \\
0.0232 \\
0.0000 \\
0.0000 \\
4.0114\end{array}$ & $\begin{array}{l}1.9442 \\
0.0069 \\
0.0558 \\
0.0487 \\
0.0104 \\
0.1984 \\
0.0063 \\
0.9095 \\
0.8078 \\
0.0172 \\
0.0000 \\
0.0000 \\
4.0052\end{array}$ & $\begin{array}{l}1.8929 \\
0.0175 \\
0.1071 \\
0.0699 \\
0.0244 \\
0.1685 \\
0.0041 \\
0.8707 \\
0.8348 \\
0.0222 \\
0.0000 \\
0.0000 \\
4.0122\end{array}$ & $\begin{array}{l}1.8453 \\
0.0309 \\
0.1547 \\
0.0838 \\
0.0392 \\
0.2364 \\
0.0050 \\
0.7943 \\
0.7998 \\
0.0302 \\
0.0000 \\
0.0000 \\
4.0196\end{array}$ & $\begin{array}{l}1.8913 \\
0.0277 \\
0.1087 \\
0.0345 \\
0.0433 \\
0.2715 \\
0.0076 \\
0.8378 \\
0.7748 \\
0.0245 \\
0.0000 \\
0.0000 \\
4.0217\end{array}$ & $\begin{array}{l}1.8881 \\
0.0227 \\
0.1119 \\
0.0442 \\
0.0490 \\
0.2189 \\
0.0079 \\
0.8383 \\
0.8168 \\
0.0267 \\
0.0000 \\
0.0000 \\
4.0245\end{array}$ & $\begin{array}{l}1.8772 \\
0.0185 \\
0.1228 \\
0.0554 \\
0.0536 \\
0.1649 \\
0.0051 \\
0.8649 \\
0.8413 \\
0.0232 \\
0.0000 \\
0.0000 \\
4.0268\end{array}$ & $\begin{array}{l}1.8801 \\
0.0183 \\
0.1199 \\
0.0456 \\
0.0638 \\
0.2076 \\
0.0060 \\
0.8410 \\
0.8234 \\
0.0262 \\
0.0000 \\
0.0000 \\
4.0319\end{array}$ & $\begin{array}{l}1.8785 \\
0.0225 \\
0.1215 \\
0.0788 \\
0.0235 \\
0.1789 \\
0.0063 \\
0.8426 \\
0.8334 \\
0.0258 \\
0.0000 \\
0.0000 \\
4.0117\end{array}$ & $\begin{array}{l}1.9385 \\
0.0102 \\
0.0615 \\
0.0474 \\
0.0122 \\
0.1855 \\
0.0068 \\
0.09294 \\
0.7962 \\
0.0184 \\
0.0000 \\
0.0000 \\
4.0061\end{array}$ & $\begin{array}{l}1.8761 \\
0.0207 \\
0.1239 \\
0.0869 \\
0.0212 \\
0.1982 \\
0.0062 \\
0.8657 \\
0.7860 \\
0.0257 \\
0.0000 \\
0.0000 \\
4.0106\end{array}$ & $\begin{array}{l}1.9423 \\
0.0105 \\
0.0577 \\
0.0524 \\
0.0050 \\
0.1967 \\
0.0062 \\
0.9104 \\
0.8007 \\
0.0206 \\
0.0000 \\
0.0000 \\
4.0025\end{array}$ & $\begin{array}{l}1.8796 \\
0.0218 \\
0.1204 \\
0.0864 \\
0.0160 \\
0.1943 \\
0.0062 \\
0.8540 \\
0.8036 \\
0.0256 \\
0.0000 \\
0.0000 \\
4.0080\end{array}$ & $\begin{array}{l}1.9415 \\
0.0096 \\
0.0585 \\
0.0551 \\
0.0026 \\
0.1954 \\
0.0053 \\
0.9208 \\
0.7942 \\
0.0184 \\
0.0000 \\
0.0000 \\
4.0013\end{array}$ & $\begin{array}{l}1.9364 \\
0.0133 \\
0.0636 \\
0.0527 \\
0.0036 \\
0.2427 \\
0.0050 \\
0.8524 \\
0.8128 \\
0.0193 \\
0.0000 \\
0.0000 \\
4.0018\end{array}$ \\
\hline $\begin{array}{l}\text { Ac } \\
\text { Jd } \\
\text { FeCaTs } \\
\text { CrCaTs } \\
\text { AlCaTs }\end{array}$ & $\begin{array}{l}0.0291 \\
0.0000 \\
0.0133 \\
0.0000 \\
0.0434\end{array}$ & $\begin{array}{l}0.0228 \\
0.0003 \\
0.0000 \\
0.0000 \\
0.0226\end{array}$ & $\begin{array}{l}0.0104 \\
0.0068 \\
0.0000 \\
0.0000 \\
0.0419\end{array}$ & $\begin{array}{l}0.0222 \\
0.0000 \\
0.0022 \\
0.0000 \\
0.0699\end{array}$ & $\begin{array}{l}0.0302 \\
0.0000 \\
0.0090 \\
0.0000 \\
0.0838\end{array}$ & $\begin{array}{l}0.0245 \\
0.0000 \\
0.0188 \\
0.0000 \\
0.0345\end{array}$ & $\begin{array}{l}0.0267 \\
0.0000 \\
0.0223 \\
0.0000 \\
0.0442\end{array}$ & $\begin{array}{l}0.0232 \\
0.0000 \\
0.0304 \\
0.0000 \\
0.0554\end{array}$ & $\begin{array}{l}0.0262 \\
0.0000 \\
0.0376 \\
0.0000 \\
0.0456\end{array}$ & $\begin{array}{l}0.0235 \\
0.0024 \\
0.0000 \\
0.0000 \\
0.0764\end{array}$ & $\begin{array}{l}0.8 \\
0.8 \\
0.0 \\
0.0\end{array}$ & $\begin{array}{l}12 \\
45 \\
00 \\
00 \\
24\end{array}$ & & & & \\
\hline $\begin{array}{l}\text { No } \\
\text { En } \\
\text { Fs } \\
\text { Mg* }\end{array}$ & $\begin{array}{r}0.3995 \\
0.4742 \\
0.1263 \\
79.0\end{array}$ & $\begin{array}{r}0.3954 \\
0.4502 \\
0.1544 \\
74.5\end{array}$ & $\begin{array}{l}0.3882 \\
0.5023 \\
0.1096 \\
82.1\end{array}$ & $\begin{array}{r}0.3925 \\
0.5090 \\
0.0985 \\
83.8\end{array}$ & $\begin{array}{r}0.3686 \\
0.4866 \\
0.1448 \\
7.1\end{array}$ & $\begin{array}{l}0.3729 \\
0.4736 \\
0.1534 \\
75.5\end{array}$ & $\begin{array}{l}0.3885 \\
0.4849 \\
0.1266 \\
79.3\end{array}$ & $\begin{array}{l}0.3894 \\
0.5129 \\
0.0978 \\
84.0\end{array}$ & $\begin{array}{r}0.3832 \\
0.4947 \\
0.1221 \\
80.2\end{array}$ & $\begin{array}{l}0.3902 \\
0.5030 \\
0.1068 \\
82.5\end{array}$ & $\begin{array}{r}0.3836 \\
0.5139 \\
0.1025 \\
83.4\end{array}$ & $\begin{array}{r}0.3624 \\
0.5188 \\
0.1188 \\
81.4\end{array}$ & $\begin{array}{r}0.3844 \\
0.5062 \\
0.1094 \\
82.2\end{array}$ & $\begin{array}{r}0.3714 \\
0.5121 \\
0.1165 \\
81.5\end{array}$ & $\begin{array}{r}0.3787 \\
0.5125 \\
0.1088 \\
82.5\end{array}$ & \\
\hline
\end{tabular}




\begin{tabular}{|c|c|c|c|c|c|c|c|c|c|c|c|c|c|c|c|c|}
\hline $\begin{array}{l}\text { Strat\# } \\
\text { Field\# } \\
\text { Graín } \\
\text { Anal\# }\end{array}$ & $\begin{array}{r}c P-07 \\
85 \mathrm{cns} 60 \\
c 4 r \\
131\end{array}$ & $\begin{array}{r}c P-07 \\
85 \mathrm{cns} 60 \\
c 5 c \\
139\end{array}$ & $\begin{array}{r}\text { cP-07 } \\
85 \mathrm{cns} 60 \\
\mathrm{c} 6=03 \mathrm{j} \\
133\end{array}$ & $\begin{array}{r}\text { CP- } 07 \\
85 \mathrm{cns} 60 \\
\text { pg1c } \\
138\end{array}$ & $\begin{array}{r}\mathrm{cP}-12 \\
85 \mathrm{cns} 20 \\
\mathrm{c1c} \\
254\end{array}$ & $\begin{array}{r}\text { cP-12 } \\
85 \mathrm{cns} 20 \\
\mathrm{c} 1 \mathrm{r} \\
255\end{array}$ & $\begin{array}{r}\mathrm{CP}-12 \\
85 \mathrm{cns} 20 \\
\mathrm{c2c} \\
256\end{array}$ & $\begin{array}{r}c P-12 \\
85 \mathrm{cns} 20 \\
c 2 r \\
257\end{array}$ & $\begin{array}{r}c p-12 \\
85 c n s 20 \\
c 3 c \\
258\end{array}$ & $\begin{array}{r}\text { CP-12 } \\
85 \text { cns20 } \\
\text { c3r } \\
259\end{array}$ & $\begin{array}{r}\mathrm{CP}-12 \\
85 \mathrm{cns} 20 \\
\mathrm{C} 4 \mathrm{~g} \\
260\end{array}$ & $\begin{array}{r}\text { PuM-17 } \\
85 \mathrm{cns} 17 \\
\mathrm{c1c} \\
246\end{array}$ & $\begin{array}{r}\text { PUM-17 } \\
85 \mathrm{cns} 17 \\
\mathrm{c} 1 \mathrm{r} \\
247\end{array}$ & $\begin{array}{r}\text { PUM-17 } \\
85 \mathrm{cns} 17 \\
\mathrm{c2c} \\
248\end{array}$ & $\begin{array}{r}\text { PUN-17 } \\
85 \mathrm{cns} 17 \\
\mathrm{c2r} \\
249\end{array}$ & $\begin{array}{r}\text { PUM- } 17 \\
85 \mathrm{cns} 17 \\
\mathrm{c} 3 \mathrm{c} \\
250\end{array}$ \\
\hline $\begin{array}{l}\text { wtX } \\
\text { Sioz } \\
\text { Ti02 } \\
\text { Al203 } \\
\text { fe203 } \\
\text { feo } \\
\text { MnO } \\
\text { MgO } \\
\text { CaO } \\
\text { Na20 } \\
\text { Cr203 } \\
\text { tot } \\
\text { feO meas }\end{array}$ & $\begin{array}{r}51.75 \\
0.50 \\
4.23 \\
0.70 \\
6.32 \\
0.19 \\
16.54 \\
19.68 \\
0.31 \\
\text { na } \\
100.22 \\
6.95\end{array}$ & $\begin{array}{r}51.10 \\
0.71 \\
4.07 \\
1.40 \\
6.72 \\
0.17 \\
15.61 \\
20.43 \\
0.32 \\
100.53 \\
7.98\end{array}$ & $\begin{array}{r}51.76 \\
0.38 \\
2.38 \\
1.55 \\
5.88 \\
0.22 \\
16.91 \\
19.82 \\
0.28 \\
n a \\
99.18 \\
7.27\end{array}$ & $\begin{array}{r}51.21 \\
0.65 \\
1.88 \\
1.42 \\
9.93 \\
0.29 \\
13.96 \\
19.94 \\
0.39 \\
\text { na } \\
99.67 \\
11.21\end{array}$ & $\begin{array}{r}51.45 \\
0.72 \\
2.50 \\
1.99 \\
7.27 \\
0.26 \\
15.72 \\
20.25 \\
0.34 \\
0.00 \\
100.50 \\
9.06\end{array}$ & $\begin{array}{r}52.59 \\
0.39 \\
1.78 \\
0.98 \\
8.66 \\
0.32 \\
16.34 \\
19.09 \\
0.24 \\
0.03 \\
100.42 \\
9.54\end{array}$ & $\begin{array}{r}50.04 \\
0.95 \\
4.08 \\
2.12 \\
7.00 \\
0.24 \\
14.57 \\
20.71 \\
0.41 \\
0.02 \\
100.14 \\
8.91\end{array}$ & $\begin{array}{r}52.36 \\
0.32 \\
1.79 \\
0.85 \\
8.34 \\
0.27 \\
15.82 \\
19.79 \\
0.24 \\
0.01 \\
99.80 \\
9.11\end{array}$ & $\begin{array}{r}51.47 \\
0.50 \\
2.75 \\
1.70 \\
7.40 \\
0.26 \\
15.66 \\
19.95 \\
0.35 \\
0.00 \\
100.04 \\
8.93\end{array}$ & $\begin{array}{r}51.88 \\
0.53 \\
1.82 \\
1.48 \\
7.45 \\
0.29 \\
15.93 \\
20.20 \\
0.25 \\
0.00 \\
99.83 \\
8.78\end{array}$ & $\begin{array}{r}52.21 \\
0.56 \\
1.83 \\
0.99 \\
8.11 \\
0.32 \\
16.08 \\
19.43 \\
0.30 \\
0.01 \\
99.84 \\
9.00\end{array}$ & $\begin{array}{r}51.17 \\
0.66 \\
3.39 \\
1.65 \\
7.41 \\
0.25 \\
14.88 \\
20.60 \\
0.42 \\
0.00 \\
100.44 \\
8.90\end{array}$ & $\begin{array}{r}51.04 \\
0.82 \\
3.52 \\
1.37 \\
8.04 \\
0.34 \\
14.97 \\
19.95 \\
0.38 \\
0.04 \\
100.47 \\
9.27\end{array}$ & $\begin{array}{r}51.03 \\
0.82 \\
3.62 \\
1.61 \\
7.97 \\
0.31 \\
14.77 \\
20.42 \\
0.37 \\
0.00 \\
100.92 \\
9.42\end{array}$ & $\begin{array}{r}51.43 \\
0.59 \\
2.63 \\
1.32 \\
7.67 \\
0.33 \\
14.79 \\
20.68 \\
0.38 \\
0.01 \\
99.83 \\
8.86\end{array}$ & $\begin{array}{r}52.62 \\
0.42 \\
1.78 \\
1.42 \\
7.93 \\
0.33 \\
16.18 \\
19.64 \\
0.36 \\
0.02 \\
100.70 \\
9.21\end{array}$ \\
\hline $\begin{array}{l}\text { atoms/6 } \\
\text { si } \\
\text { Ti } \\
\text { Al t } \\
\text { Al o } \\
\text { Fe3+ } \\
\text { Fe2+ } \\
\text { Mn } \\
\mathrm{Mg} \\
\mathrm{Ca} \\
\mathrm{Ma} \\
\mathrm{Mi} \\
\mathrm{Cr} \\
\text { tot }\end{array}$ & $\begin{array}{l}1.8963 \\
0.0138 \\
0.1037 \\
0.0790 \\
0.0192 \\
0.1938 \\
0.0059 \\
0.9032 \\
0.7727 \\
0.0220 \\
0.0000 \\
0.0000 \\
4.0096\end{array}$ & $\begin{array}{l}1.8839 \\
0.0197 \\
0.1161 \\
0.0608 \\
0.0388 \\
0.2072 \\
0.0053 \\
0.8577 \\
0.8070 \\
0.0229 \\
0.0000 \\
0.0000 \\
4.0194\end{array}$ & $\begin{array}{l}1.9256 \\
0.0106 \\
0.0744 \\
0.0300 \\
0.0433 \\
0.1829 \\
0.0069 \\
0.9376 \\
0.7901 \\
0.0202 \\
0.0000 \\
0.0000 \\
4.0216\end{array}$ & $\begin{array}{l}1.9338 \\
0.0185 \\
0.0662 \\
0.0175 \\
0.0404 \\
0.3136 \\
0.0093 \\
0.7856 \\
0.8068 \\
0.0286 \\
0.0000 \\
0.0000 \\
4.0202\end{array}$ & $\begin{array}{l}1.9096 \\
0.0201 \\
0.0904 \\
0.0190 \\
0.0557 \\
0.2255 \\
0.0082 \\
0.8695 \\
0.8053 \\
0.0245 \\
0.0000 \\
0.0000 \\
4.0278\end{array}$ & $\begin{array}{l}1.9449 \\
0.0108 \\
0.0551 \\
0.0225 \\
0.0272 \\
0.2678 \\
0.0100 \\
0.9006 \\
0.7565 \\
0.0172 \\
0.0000 \\
0.0009 \\
4.0136\end{array}$ & $\begin{array}{l}1.8683 \\
0.0267 \\
0.1317 \\
0.0479 \\
0.0596 \\
0.2186 \\
0.0076 \\
0.8107 \\
0.8285 \\
0.0297 \\
0.0000 \\
0.0006\end{array}$ & $\begin{array}{l}1.9484 \\
0.0090 \\
0.0516 \\
0.0269 \\
0.0238 \\
0.2597 \\
0.0085 \\
0.8773 \\
0.7891 \\
0.0173 \\
0.0000 \\
0.0003\end{array}$ & $\begin{array}{l}1.9146 \\
0.0140 \\
0.0854 \\
0.0352 \\
0.0475 \\
0.2303 \\
0.0082 \\
0.8682 \\
0.7952 \\
0.0252 \\
0.0000 \\
0.0000 \\
4.0237\end{array}$ & $\begin{array}{l}1.9335 \\
0.0149 \\
0.0665 \\
0.0135 \\
0.0414 \\
0.2323 \\
0.0092 \\
0.8848 \\
0.8067 \\
0.0181 \\
0.0000 \\
0.0000 \\
4.0207\end{array}$ & $\begin{array}{l}1.8 \\
0.0 \\
0.0 \\
0.0 \\
0.0 \\
0.0 \\
0.0 \\
0.8 \\
0.7 \\
0.0 \\
0.0 \\
0.0\end{array}$ & $\begin{array}{l}1 . \\
0 . \\
0 . \\
0 . \\
0 . \\
0 . \\
0 . \\
0 . \\
0 . \\
0 . \\
0 . \\
0 .\end{array}$ & $\begin{array}{l}1.8 \\
0.0 \\
0.1 \\
0.0 \\
0.0 \\
0.2 \\
0.0 \\
0.8 \\
0.7 \\
0.0 \\
0.0 \\
0.0\end{array}$ & $\begin{array}{l}90 \\
28 \\
10 \\
70 \\
49 \\
69 \\
97 \\
48 \\
199 \\
696 \\
100 \\
00 \\
25\end{array}$ & & $\begin{array}{l}1 \\
0 \\
0 \\
0 \\
0 \\
0 \\
0 \\
0 \\
0 \\
0 \\
0 \\
0\end{array}$ \\
\hline $\begin{array}{l}\text { Ac } \\
\text { Jd } \\
\text { FeCars } \\
\text { CrCars } \\
\text { AlCats }\end{array}$ & $\begin{array}{l}0.0192 \\
0.0028 \\
0.0000 \\
0.0000 \\
0.0762\end{array}$ & $\begin{array}{l}0.0229 \\
0.0000 \\
0.0160 \\
0.0000 \\
0.0608\end{array}$ & $\begin{array}{l}0.0202 \\
0.0000 \\
0.0231 \\
0.0000 \\
0.0300\end{array}$ & $\begin{array}{l}0.0286 \\
0.0000 \\
0.0119 \\
0.0000 \\
0.0175\end{array}$ & $\begin{array}{l}0.0245 \\
0.0000 \\
0.0312 \\
0.0000 \\
0.0190\end{array}$ & $\begin{array}{l}0.0172 \\
0.0000 \\
0.0100 \\
0.0009 \\
0.0225\end{array}$ & $\begin{array}{l}0.0297 \\
0.0000 \\
0.0299 \\
0.0006 \\
0.0479\end{array}$ & $\begin{array}{l}0.0173 \\
0.0000 \\
0.0065 \\
0.0003 \\
0.0269\end{array}$ & $\begin{array}{l}0.0252 \\
0.0000 \\
0.0222 \\
0.0000 \\
0.0352\end{array}$ & $\begin{array}{l}0.0 \\
0.0 \\
0.0 \\
0.0\end{array}$ & $\begin{array}{l}0.0 \\
0.0 \\
0.0 \\
0.0\end{array}$ & $\begin{array}{l}0.0 \\
0.0 \\
0.0 \\
0.0\end{array}$ & $\begin{array}{l}0.0 \\
0.0 \\
0.0 \\
0.0\end{array}$ & $\begin{array}{l}6 \\
0 \\
10 \\
14 \\
0 \\
0\end{array}$ & & \\
\hline $\begin{array}{l}\text { Wo } \\
\text { En } \\
\text { Fs } \\
\text { Mg\# }\end{array}$ & $\begin{array}{r}0.3579 \\
0.5287 \\
0.1134 \\
82.3\end{array}$ & $\begin{array}{r}0.3766 \\
0.5021 \\
0.1213 \\
80.5\end{array}$ & $\begin{array}{r}0.3786 \\
0.5200 \\
0.1014 \\
83.7\end{array}$ & $\begin{array}{r}0.4030 \\
0.4267 \\
0.1703 \\
71.5\end{array}$ & $\begin{array}{l}0.3898 \\
0.4845 \\
0.1257 \\
79.4\end{array}$ & $\begin{array}{r}0.3701 \\
0.4855 \\
0.1444 \\
77.1\end{array}$ & $\begin{array}{r}0.3899 \\
0.4805 \\
0.1296 \\
78.8\end{array}$ & $\begin{array}{r}0.3863 \\
0.4735 \\
0.1402 \\
77.2\end{array}$ & $\begin{array}{r}0.3815 \\
0.4888 \\
0.1297 \\
79.0\end{array}$ & $\begin{array}{r}0.3940 \\
0.4800 \\
0.1260 \\
79.2\end{array}$ & $\begin{array}{r}0.3840 \\
0.4801 \\
0.1359 \\
77.9\end{array}$ & $\begin{array}{r}0.3929 \\
0.4745 \\
0.1326 \\
78.2\end{array}$ & $\begin{array}{r}0.3802 \\
0.4762 \\
0.1435 \\
76.8\end{array}$ & $\begin{array}{r}0.3856 \\
0.4716 \\
0.1428 \\
76.8\end{array}$ & $\begin{array}{r}0.4044 \\
0.4613 \\
0.1343 \\
77.5\end{array}$ & $\begin{array}{r}0.3842 \\
0.4829 \\
0.1329 \\
78.4\end{array}$ \\
\hline
\end{tabular}




\begin{tabular}{|c|c|c|c|c|c|c|c|}
\hline $\begin{array}{l}\text { Strat\# } \\
\text { Field\# } \\
\text { Grain } \\
\text { Anal\# }\end{array}$ & $\begin{array}{r}\text { PUi- } 17 \\
85 \mathrm{cns} 17 \\
\mathrm{c3r} \\
251\end{array}$ & $\begin{array}{r}\text { Pum- } 17 \\
85 \mathrm{cns} 17 \\
\mathrm{c} 4 \mathrm{c} \\
252\end{array}$ & $\begin{array}{r}\text { PUin-17 } \\
85 \mathrm{cns} 17 \\
c 4 r \\
253\end{array}$ & $\min$ & $\max$ & mean & sdev \\
\hline $\begin{array}{l}\text { wt\% } \\
\text { sio2 } \\
\text { Ti02 } \\
\text { Al203 } \\
\text { fe203 } \\
\text { feO } \\
\text { MnO } \\
\text { MgO } \\
\text { CaO } \\
\text { Na20 } \\
\text { Cr203 } \\
\text { tot } \\
\text { feO meas }\end{array}$ & $\begin{array}{r}51.97 \\
0.46 \\
2.84 \\
1.44 \\
7.36 \\
0.36 \\
15.04 \\
20.97 \\
0.39 \\
0.03 \\
100.86 \\
8.66\end{array}$ & $\begin{array}{r}51.78 \\
0.54 \\
2.77 \\
1.84 \\
6.60 \\
0.29 \\
15.12 \\
21.56 \\
0.38 \\
0.02 \\
100.90 \\
8.26\end{array}$ & $\begin{array}{r}51.10 \\
0.68 \\
3.04 \\
2.31 \\
6.47 \\
0.30 \\
15.09 \\
21.22 \\
0.41 \\
0.02 \\
100.63 \\
8.54\end{array}$ & $\begin{array}{r}49.59 \\
0.20 \\
0.80 \\
0.00 \\
4.32 \\
0.12 \\
13.56 \\
19.09 \\
0.19 \\
0.00 \\
97.32 \\
5.13\end{array}$ & $\begin{array}{r}53.53 \\
1.23 \\
5.46 \\
2.64 \\
11.25 \\
0.49 \\
17.55 \\
22.27 \\
0.43 \\
0.13 \\
101.77 \\
11.32\end{array}$ & $\begin{array}{r}51.88 \\
0.53 \\
2.44 \\
1.17 \\
7.66 \\
0.28 \\
15.19 \\
20.66 \\
0.33 \\
0.01 \\
100.14 \\
8.71\end{array}$ & $\begin{array}{l}0.87 \\
0.20 \\
1.08 \\
0.53 \\
1.27 \\
0.08 \\
0.79 \\
0.67 \\
0.05 \\
0.03 \\
0.63 \\
1.31\end{array}$ \\
\hline $\begin{array}{l}\text { atoms } / 60 \\
\text { Si } \\
\text { Ii } \\
\text { Al } t \\
\text { Al } 0 \\
\text { Fe3+ } \\
\text { Fe2+ } \\
\mathrm{Mn} \\
\mathrm{Mg} \\
\mathrm{Ca} \\
\mathrm{Ma} \\
\mathrm{Mi} \\
\mathrm{Cr} \\
\text { tot }\end{array}$ & $\begin{array}{l}1.9189 \\
0.0128 \\
0.0811 \\
0.0425 \\
0.0401 \\
0.2273 \\
0.0113 \\
0.8276 \\
0.8296 \\
0.0279 \\
0.0000 \\
0.0009 \\
4.0200\end{array}$ & $\begin{array}{l}1.9124 \\
0.0150 \\
0.0876 \\
0.0331 \\
0.0511 \\
0.2040 \\
0.0091 \\
0.8323 \\
0.8532 \\
0.0272 \\
0.0000 \\
0.0006 \\
4.0256\end{array}$ & $\begin{array}{l}1.8968 \\
0.0190 \\
0.1032 \\
0.0298 \\
0.0644 \\
0.2007 \\
0.0094 \\
0.8348 \\
0.8440 \\
0.0295 \\
0.0000 \\
0.0006 \\
4.0322\end{array}$ & $\begin{array}{r}1.8453 \\
0.0056 \\
-0.0055 \\
0.0000 \\
0.0000 \\
0.1340 \\
0.0037 \\
0.7636 \\
0.7565 \\
0.0135 \\
0.0000 \\
0.0000 \\
3.9782\end{array}$ & $\begin{array}{l}2.0055 \\
0.0344 \\
0.1547 \\
0.0885 \\
0.0736 \\
0.3554 \\
0.0158 \\
0.9501 \\
0.8841 \\
0.0315 \\
0.0000 \\
0.0038 \\
4.0368\end{array}$ & $\begin{array}{l}1.9274 \\
0.0148 \\
0.0726 \\
0.0340 \\
0.0327 \\
0.2381 \\
0.0088 \\
0.8412 \\
0.8226 \\
0.0237 \\
0.0000 \\
0.0003 \\
4.0162\end{array}$ & $\begin{array}{l}0.0304 \\
0.0056 \\
0.0304 \\
0.0201 \\
0.0148 \\
0.0404 \\
0.0026 \\
0.0392 \\
0.0266 \\
0.0038 \\
0.0000 \\
0.0007 \\
0.0081\end{array}$ \\
\hline $\begin{array}{l}\text { Ac } \\
\text { Jd } \\
\text { FeCaTs } \\
\text { CrCaTs } \\
\text { AlCaTs }\end{array}$ & $\begin{array}{l}0.0279 \\
0.0000 \\
0.0122 \\
0.0009 \\
0.0425\end{array}$ & $\begin{array}{l}0.0272 \\
0.0000 \\
0.0239 \\
0.0006 \\
0.0331\end{array}$ & $\begin{array}{l}0.0295 \\
0.0000 \\
0.0349 \\
0.0006 \\
0.0298\end{array}$ & $\begin{array}{l}0.0000 \\
0.0000 \\
0.0000 \\
0.0000 \\
0.0000\end{array}$ & $\begin{array}{l}0.0315 \\
0.0272 \\
0.0528 \\
0.0038 \\
0.0872\end{array}$ & $\begin{array}{l}0.0216 \\
0.0021 \\
0.0111 \\
0.0003 \\
0.0319\end{array}$ & $\begin{array}{l}0.0066 \\
0.0049 \\
0.0107 \\
0.0007 \\
0.0195\end{array}$ \\
\hline $\begin{array}{l}\text { Wo } \\
\text { En } \\
\text { Fs } \\
\text { Mg\# }\end{array}$ & $\begin{array}{l}0.4010 \\
0.4699 \\
0.1291 \\
78.4\end{array}$ & $\begin{array}{r}0.4114 \\
0.4727 \\
0.1159 \\
80.3\end{array}$ & $\begin{array}{r}0.4041 \\
0.4804 \\
0.1155 \\
80.6\end{array}$ & $\begin{array}{r}0.3579 \\
0.4056 \\
0.0792 \\
68.2\end{array}$ & $\begin{array}{r}0.4410 \\
0.5287 \\
0.1887 \\
86.6\end{array}$ & $\begin{array}{r}0.4004 \\
0.4677 \\
0.1319 \\
78.0\end{array}$ & $\begin{array}{r}0.0182 \\
0.0298 \\
0.0199 \\
3.5\end{array}$ \\
\hline
\end{tabular}




\section{APPENDIX VI - Orthopyroxene compositions}

Plagioclase compositons were determined on the JEOL JXA-733 microprobe at Southern Methodist University using standard analytical stratagies and instrumental settings. No attempt was specifically made to optimize the instrumental settings for the determination of minor elements. 
Spurr Volcanic Complex orthopyroxene analyses

\begin{tabular}{|c|c|c|c|c|c|c|c|c|c|c|c|c|c|c|c|c|}
\hline $\begin{array}{l}\text { Strat\# } \\
\text { Field\#\# } \\
\text { Grain } \\
\text { Anal \# }\end{array}$ & $\begin{array}{r}\text { AMS-B03 } \\
85 \mathrm{SCS557} \\
03 \mathrm{C} \\
5\end{array}$ & $\begin{array}{r}\text { AMS- } 803 \\
85 \mathrm{cns57} \\
03 \mathrm{r} \\
6\end{array}$ & $\begin{array}{r}\text { AMS-B03 } \\
85 \text { ens57 } \\
05 \mathrm{C} \\
8\end{array}$ & $\begin{array}{r}\text { AMS-803 } \\
\text { BScns57 } \\
05, \\
9\end{array}$ & $\begin{array}{r}\text { AMS-B03 } \\
85 \mathrm{cns57} \\
06 \mathrm{c} \\
16\end{array}$ & $\begin{array}{r}\text { AMS- } 803 \\
\text { 85ens57 } \\
\text { O6r } \\
17\end{array}$ & $\begin{array}{r}\text { AMS-B03 } \\
85 \text { cns57 } \\
07 \mathrm{C} \\
18\end{array}$ & $\begin{array}{r}\text { AMS-B03 } \\
85 \text { ens57 } \\
07 r \\
19\end{array}$ & $\begin{array}{r}\text { AMs-B03 } \\
85 \text { cns57 } \\
08 \mathrm{C} \\
20\end{array}$ & $\begin{array}{r}\text { AMS-B03 } \\
85 \mathrm{Cns57} \\
08 \mathrm{r} \\
21\end{array}$ & $\begin{array}{r}\text { AMS- } 103 \\
85 \mathrm{cns23} \\
01 \mathrm{0} \\
56\end{array}$ & $\begin{array}{r}\text { AMS-A03 } \\
\text { BScns23 } \\
01 r \\
57\end{array}$ & $\begin{array}{r}\text { AMs- } 103 \\
85 \mathrm{cns} 23 \\
02 \mathrm{C} \\
59\end{array}$ & $\begin{array}{r}\text { AMS-A03 } \\
85 \mathrm{cns23} \\
02 \mathrm{O} \\
60\end{array}$ & $\begin{array}{r}\text { AMS- } 103 \\
85 \mathrm{cns23} \\
03 \mathrm{C} \\
62\end{array}$ & $\begin{array}{r}\text { MS-A03 } \\
\text { Sense23 } \\
03 r \\
63\end{array}$ \\
\hline $\begin{array}{l}0 \\
02 \\
002 \\
202 \\
203 \\
203 \\
=0 \\
00 \\
00 \\
00 \\
200 \\
203 \\
20\end{array}$ & $\begin{array}{r}54.96 \\
0.13 \\
1.88 \\
0.62 \\
11.55 \\
0.35 \\
29.27 \\
1.60 \\
0.01 \\
\text { na } \\
100.32 \\
12.11\end{array}$ & $\begin{array}{r}54.07 \\
0.23 \\
2.39 \\
0.93 \\
11.72 \\
0.29 \\
28.70 \\
1.44 \\
0.06 \\
99.89 \\
99.83 \\
12.56\end{array}$ & $\begin{array}{r}55.01 \\
0.10 \\
2.72 \\
0.00 \\
9.73 \\
0.24 \\
30.20 \\
1.51 \\
0.03 \\
99 \\
99.54 \\
9.73\end{array}$ & $\begin{array}{r}55.02 \\
0.18 \\
1.86 \\
00.09 \\
12.17 \\
0.25 \\
28.89 \\
1.48 \\
0.04 \\
99.09 \\
99.98 \\
12.25\end{array}$ & $\begin{array}{r}52.39 \\
0.25 \\
1.09 \\
0.89 \\
20.08 \\
0.63 \\
22.90 \\
1.29 \\
0.02 \\
99.59 \\
20.84\end{array}$ & $\begin{array}{r}52.79 \\
0.20 \\
0.83 \\
1.00 \\
19.48 \\
0.66 \\
23.52 \\
1.28 \\
0.04 \\
\text { na } \\
99.80 \\
20.38\end{array}$ & $\begin{array}{r}52.93 \\
0.10 \\
3.25 \\
1.89 \\
10.67 \\
0.27 \\
28.85 \\
1.39 \\
0.02 \\
99.19 \\
12.37 \\
12.37\end{array}$ & $\begin{array}{r}53.97 \\
0.12 \\
1.08 \\
0.90 \\
14.35 \\
0.36 \\
27.02 \\
1.63 \\
0.02 \\
99.06 \\
99.45 \\
15.16\end{array}$ & $\begin{array}{r}53.96 \\
0.08 \\
1.57 \\
0.54 \\
13.50 \\
0.30 \\
27.37 \\
1.65 \\
0.03 \\
\text { na } \\
99.00 \\
13.99\end{array}$ & $\begin{array}{r}53.36 \\
0.09 \\
1.27 \\
0.00 \\
19.11 \\
0.48 \\
23.83 \\
1.12 \\
0.03 \\
\text { na } \\
99.29 \\
19.11\end{array}$ & $\begin{array}{r}52.59 \\
0.24 \\
0.89 \\
0.94 \\
18.86 \\
0.66 \\
23.82 \\
1.29 \\
0.01 \\
\text { na } \\
99.30 \\
19.71\end{array}$ & $\begin{array}{r}52.68 \\
0.22 \\
0.89 \\
0.26 \\
20.08 \\
0.66 \\
22.91 \\
1.24 \\
0.03 \\
02 \\
98.98 \\
20.32\end{array}$ & $\begin{array}{r}51.95 \\
0.20 \\
1.49 \\
1.42 \\
20.22 \\
0.70 \\
22.81 \\
1.02 \\
0.01 \\
99.79 \\
21.50\end{array}$ & $\begin{array}{r}53.08 \\
0.05 \\
0.64 \\
0.64 \\
19.81 \\
0.86 \\
23.30 \\
1.14 \\
0.03 \\
\text { na } \\
99.54 \\
20.38\end{array}$ & $\begin{array}{r}52.57 \\
0.18 \\
0.93 \\
1.12 \\
17.94 \\
0.66 \\
24.27 \\
1.29 \\
0.01 \\
\text { no } \\
98.97 \\
18.95\end{array}$ & $\begin{array}{r}52.80 \\
0.23 \\
0.95 \\
0.70 \\
19.01 \\
0.56 \\
23.76 \\
1.21 \\
0.04 \\
99.26 \\
19.26 \\
19.64\end{array}$ \\
\hline $\begin{array}{l}\text { toms/60 } \\
t \\
0 \\
03+ \\
2+ \\
2+\end{array}$ & $\begin{array}{l}1.9493 \\
0.0055 \\
0.0507 \\
0.0279 \\
0.0165 \\
0.3427 \\
0.0090 \\
1.5472 \\
0.0608 \\
0.0007 \\
0.0000 \\
0.0000\end{array}$ & $\begin{array}{l}1.9330 \\
0.0062 \\
0.0670 \\
0.0337 \\
0.0251 \\
0.3504 \\
0.0088 \\
1.05291 \\
0.0552 \\
0.0042 \\
0.0000 \\
0.0000\end{array}$ & $\begin{array}{l}1.9418 \\
0.0027 \\
0.0582 \\
0.0550 \\
0.0000 \\
0.2872 \\
0.0072 \\
1.58877 \\
0.0571 \\
0.0021 \\
0.0000 \\
0.0000 \\
4.0000\end{array}$ & $\begin{array}{l}1.9564 \\
0.0048 \\
0.0436 \\
0.0344 \\
0.0023 \\
0.3620 \\
0.0075 \\
1.5310 \\
0.0564 \\
0.0028 \\
0.0000\end{array}$ & $\begin{array}{l}1.9572 \\
0.0070 \\
0.0428 \\
0.0052 \\
0.0251 \\
0.6273 \\
0.0199 \\
. .2750 \\
0.0516 \\
0.0014 \\
0.0000 \\
0.0000 \\
4.0125\end{array}$ & $\begin{array}{l}1.9623 \\
0.0056 \\
0.0364 \\
0.0000 \\
0.0281 \\
0.0055 \\
0.0208 \\
1.0029 \\
0.0510 \\
0.0029 \\
0.0000 \\
0.0000\end{array}$ & $\begin{array}{l}1.9035 \\
0.0027 \\
0.0965 \\
0.0413 \\
0.0511 \\
0.3209 \\
0.0082 \\
1.5463 \\
0.0536 \\
0.0014 \\
0.0000 \\
0.0000\end{array}$ & $\begin{array}{l}1.9620 \\
0.0033 \\
0.0380 \\
0.0083 \\
0.0246 \\
0.4363 \\
0.0111 \\
1.4639 \\
0.0635 \\
0.0014 \\
0.0000 \\
0.0000 \\
4.0123\end{array}$ & $\begin{array}{l}1.9579 \\
0.0022 \\
0.0421 \\
0.0251 \\
0.0147 \\
0.4098 \\
0.0092 \\
1.4801 \\
0.0642 \\
0.0021 \\
0.0000 \\
0.0000 \\
4.0074\end{array}$ & 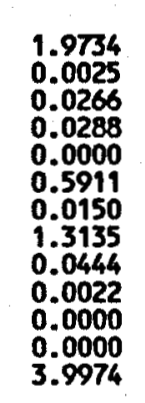 & $\begin{array}{l}1.9593 \\
0.0067 \\
0.0391 \\
0.0000 \\
0.0264 \\
0.5878 \\
0.0208 \\
. .3226 \\
0.0515 \\
0.0007 \\
0.0000 \\
0.0000 \\
4.0148\end{array}$ & $\begin{array}{l}16 \\
62 \\
64 \\
08 \\
74 \\
36 \\
09 \\
78 \\
97 \\
22 \\
00\end{array}$ & 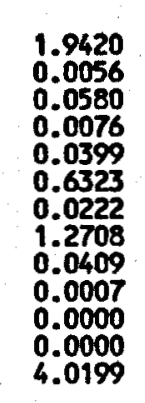 & & $\begin{array}{l}8 \\
0 \\
9 \\
0 \\
5 \\
0 \\
8 \\
8 \\
5 \\
7 \\
10\end{array}$ & \\
\hline 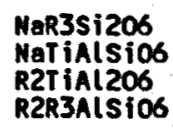 & $\begin{array}{l}0.0007 \\
0.0000 \\
0.0035 \\
0.0438\end{array}$ & $\begin{array}{l}0.0000 \\
0.0062 \\
0.0547\end{array}$ & $\begin{array}{l}0.0021 \\
0.0000 \\
0.0027 \\
0.0529\end{array}$ & $\begin{array}{l}0.0 \\
0.0 \\
0.0\end{array}$ & $\begin{array}{l}00 \\
70 \\
88\end{array}$ & $\begin{array}{l}0.0 \\
0.0 \\
0.0\end{array}$ & $\begin{array}{l}0.1 \\
0.4 \\
0.0 \\
0.8\end{array}$ & & & & & & & & & \\
\hline $\begin{array}{l}\text { Wo } \\
\text { En } \\
\text { Fs } \\
\text { Mg\# }\end{array}$ & $\begin{array}{l}0.0319 \\
0.7925 \\
0.1755 \\
81.9\end{array}$ & $\begin{array}{l}0.029 \\
0.7899 \\
0.180 \\
81 .\end{array}$ & $\begin{array}{l}0.0304 \\
0.8211 \\
0.1485 \\
84.7\end{array}$ & $\begin{array}{l}0.0295 \\
0.7849 \\
0.1856 \\
80.9\end{array}$ & $\begin{array}{l}0.0269 \\
0.6522 \\
0.3209 \\
67.0\end{array}$ & $\begin{array}{l}0 \\
0\end{array}$ & $\begin{array}{l}0.0293 \\
0.8038 \\
0.1668 \\
82.8\end{array}$ & $\begin{array}{l}0.03 \\
0.74 \\
0.22 \\
77\end{array}$ & $\begin{array}{l}0.0335 \\
0.7369 \\
0.2096 \\
78.3\end{array}$ & & $\begin{array}{l}0.0267 \\
0.6738 \\
0.2995 \\
69.2\end{array}$ & & $\begin{array}{l}0.0216 \\
0.6533 \\
0.3251 \\
66.8\end{array}$ & & & \\
\hline
\end{tabular}

mineral calculations after Lindsley (1983) 


\begin{tabular}{|c|c|c|c|c|c|c|c|c|c|c|c|c|c|c|c|c|}
\hline $\begin{array}{l}\text { Strat\# } \\
\text { Field\# } \\
\text { Grain } \\
\text { Anal\# }\end{array}$ & $\begin{array}{r}\text { AMS-A03 } \\
85 \mathrm{cns23} \\
04 \mathrm{C} \\
64\end{array}$ & $\begin{array}{r}\text { AMs- } 103 \\
85 \mathrm{cns23} \\
04 \mathrm{r} \\
65\end{array}$ & $\begin{array}{r}\text { AMS-A03 } \\
85 \text { ens23 } \\
05 \mathrm{c} \\
66\end{array}$ & $\begin{array}{r}\text { AMs }-103 \\
85 \mathrm{cns} 23 \\
05 \mathrm{r} \\
67\end{array}$ & $\begin{array}{r}\text { AMS-A03 } \\
85 \mathrm{cns} 23 \\
06 \mathrm{~g} \\
58\end{array}$ & $\begin{array}{r}\text { Af-08 } \\
85 \text { ens08 } \\
01 c \\
174\end{array}$ & $\begin{array}{r}\text { AF- } 08 \\
85 \mathrm{cns} 08 \\
01 \mathrm{r} \\
175\end{array}$ & $\begin{array}{r}\text { AF-08 } \\
85 \mathrm{cns} 08 \\
02 \mathrm{C} \\
176\end{array}$ & $\begin{array}{r}\text { AF-08 } \\
85 \mathrm{cns} 08 \\
025 \\
177\end{array}$ & $\begin{array}{r}\text { AF-08 } \\
\text { 85ens08 } \\
03 \mathrm{C} \\
178\end{array}$ & $\begin{array}{r}A F-08 \\
85 \mathrm{cns08} \\
03 r \\
179\end{array}$ & $\begin{array}{r}A F-08 \\
85 \text { ens08 } \\
04 \mathrm{c} \\
180\end{array}$ & $\begin{array}{r}\text { AF-08 } \\
85 \mathrm{cns} 08 \\
04 r \\
181\end{array}$ & $\begin{array}{r}A F-08 \\
85 \mathrm{cns08} \\
05 \mathrm{c} \\
182\end{array}$ & $\begin{array}{r}\text { AF-08 } \\
85 \text { cns08 } \\
05 r \\
183\end{array}$ & $\begin{array}{r}\text { AF- } 09 \\
85 \mathrm{cns} 09 \\
01 \mathrm{c} \\
199\end{array}$ \\
\hline 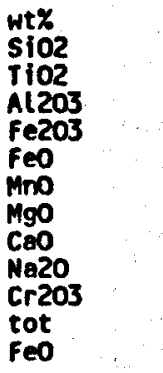 & $\begin{array}{r}53.69 \\
0.18 \\
0.70 \\
0.81 \\
18.68 \\
0.64 \\
24.57 \\
1.53 \\
0.03 \\
\text { na } \\
100.83 \\
19.41\end{array}$ & $\begin{array}{r}52.85 \\
0.19 \\
0.92 \\
0.69 \\
19.92 \\
0.78 \\
23.13 \\
1.29 \\
0.02 \\
\text { na } \\
99.79 \\
20.54\end{array}$ & $\begin{array}{r}52.07 \\
0.21 \\
0.91 \\
1.08 \\
20.27 \\
0.68 \\
22.53 \\
1.33 \\
0.03 \\
\text { na } \\
99.11 \\
21.24\end{array}$ & $\begin{array}{r}52.65 \\
0.18 \\
0.86 \\
1.07 \\
19.89 \\
0.71 \\
23.22 \\
1.34 \\
0.03 \\
\text { na } \\
99.95 \\
20.85\end{array}$ & $\begin{array}{r}52.49 \\
0.25 \\
1.04 \\
1.12 \\
18.86 \\
0.70 \\
23.58 \\
1.45 \\
0.01 \\
\text { na } \\
99.49 \\
19.86\end{array}$ & $\begin{array}{r}53.02 \\
0.21 \\
0.86 \\
0.86 \\
20.61 \\
0.77 \\
22.94 \\
1.22 \\
0.03 \\
0.00 \\
100.52 \\
21.38\end{array}$ & $\begin{array}{r}53.31 \\
0.21 \\
0.62 \\
0.52 \\
21.17 \\
0.68 \\
22.95 \\
1.10 \\
0.00 \\
0.03 \\
100.59 \\
21.64\end{array}$ & $\begin{array}{r}53.15 \\
0.18 \\
0.55 \\
0.53 \\
23.09 \\
0.78 \\
21.94 \\
1.07 \\
0.01 \\
0.00 \\
101.29 \\
23.56\end{array}$ & $\begin{array}{r}53.05 \\
0.16 \\
0.60 \\
0.62 \\
21.55 \\
0.71 \\
22.60 \\
1.10 \\
0.02 \\
0.05 \\
100.46 \\
22.11\end{array}$ & $\begin{array}{r}53.68 \\
0.18 \\
0.69 \\
0.40 \\
20.10 \\
0.70 \\
23.54 \\
1.27 \\
0.03 \\
0.00 \\
100.59 \\
20.46\end{array}$ & $\begin{array}{r}53.19 \\
0.22 \\
0.62 \\
0.57 \\
20.90 \\
0.70 \\
22.82 \\
1.38 \\
0.02 \\
0.01 \\
100.44 \\
21.42\end{array}$ & $\begin{array}{r}53.05 \\
0.22 \\
0.93 \\
1.03 \\
20.48 \\
0.75 \\
23.08 \\
1.27 \\
0.02 \\
0.03 \\
100.86 \\
21.41\end{array}$ & $\begin{array}{r}53.01 \\
0.29 \\
0.70 \\
0.58 \\
20.95 \\
0.68 \\
22.81 \\
1.27 \\
0.03 \\
0.01 \\
100.34 \\
21.48\end{array}$ & $\begin{array}{r}53.15 \\
0.18 \\
0.68 \\
0.29 \\
22.89 \\
0.68 \\
21.72 \\
1.18 \\
0.01 \\
0.07 \\
100.85 \\
23.15\end{array}$ & $\begin{array}{r}53.67 \\
0.11 \\
0.43 \\
0.48 \\
21.69 \\
0.68 \\
23.09 \\
1.00 \\
0.01 \\
0.00 \\
101.16 \\
22.12\end{array}$ & $\begin{array}{r}52.84 \\
0.17 \\
1.10 \\
0.64 \\
20.34 \\
0.66 \\
22.88 \\
1.29 \\
0.04 \\
0.03 \\
99.99 \\
20.92\end{array}$ \\
\hline $\begin{array}{l}\text { atoms } / 60 \\
\text { Si } \\
\text { II } \\
\text { Al t } \\
\text { Al o } \\
\text { Fe3+ } \\
\text { Fe2+ } \\
\mathrm{Mn} \\
\mathrm{Mg} \\
\mathrm{Ca} \\
\mathrm{Na} \\
\mathrm{Mi} \\
\mathrm{Cr} \\
\text { tot }\end{array}$ & $\begin{array}{l}1.9649 \\
0.0050 \\
0.0302 \\
0.0000 \\
0.0224 \\
0.5717 \\
0.0198 \\
1.3401 \\
0.0600 \\
0.0021 \\
0.0000 \\
0.0000 \\
4.0161\end{array}$ & $\begin{array}{l}1.9656 \\
0.0053 \\
0.0344 \\
0.0059 \\
0.0193 \\
0.6196 \\
0.0246 \\
1.2821 \\
0.0514 \\
0.0014 \\
0.0000 \\
0.0000 \\
4.0096\end{array}$ & $\begin{array}{l}1.9595 \\
0.0059 \\
0.0404 \\
0.0000 \\
0.0307 \\
0.0378 \\
0.0217 \\
1.2636 \\
0.0536 \\
0.0022 \\
0.0000 \\
0.0000 \\
4.0154\end{array}$ & $\begin{array}{l}1.9597 \\
0.0050 \\
0.0377 \\
0.0000 \\
0.0298 \\
0.6192 \\
0.0224 \\
1.2880 \\
0.0534 \\
0.0022 \\
0.0000 \\
0.0000 \\
4.0175\end{array}$ & $\begin{array}{l}1.9549 \\
0.0070 \\
0.0451 \\
0.0006 \\
0.0313 \\
0.5873 \\
0.0221 \\
1.3088 \\
0.0579 \\
0.0007 \\
0.0000 \\
0.0000 \\
4.0156\end{array}$ & $\begin{array}{l}1.9645 \\
0.0059 \\
0.0355 \\
0.0021 \\
0.0239 \\
0.6386 \\
0.0242 \\
1.2667 \\
0.0484 \\
0.0022 \\
0.0000 \\
0.0000 \\
4.0119\end{array}$ & $\begin{array}{l}1.9729 \\
0.0058 \\
0.0271 \\
0.0000 \\
0.0145 \\
0.6553 \\
0.0213 \\
1.2658 \\
0.0436 \\
0.0000 \\
0.0000 \\
0.0009 \\
4.0073\end{array}$ & $\begin{array}{l}1.9714 \\
0.0050 \\
0.0241 \\
0.0000 \\
0.0147 \\
0.7161 \\
0.0245 \\
1.2128 \\
0.0425 \\
0.0007 \\
0.0000 \\
0.0000 \\
4.0119\end{array}$ & $\begin{array}{l}1.9717 \\
0.0045 \\
0.0263 \\
0.0000 \\
0.0173 \\
0.6699 \\
0.0224 \\
1.2518 \\
0.0438 \\
0.0014 \\
0.0000 \\
0.0015 \\
4.0107\end{array}$ & $\begin{array}{l}1.9756 \\
0.0050 \\
0.0244 \\
0.0056 \\
0.0110 \\
0.6188 \\
0.0218 \\
1.2912 \\
0.0501 \\
0.0021 \\
0.0000 \\
0.0000 \\
4.0055\end{array}$ & $\begin{array}{l}0.0 \\
0.0 \\
0.0 \\
0.0 \\
0.6 \\
0.0 \\
1.2 \\
0.0 \\
0.0 \\
0.0 \\
0.0 \\
4.0\end{array}$ & $\begin{array}{l}0.2 \\
0.0 \\
0.0 \\
0.0 \\
0.0 \\
0.0 \\
0.0 \\
1.2 \\
0.0 \\
0.0 \\
0.0 \\
0.0 \\
4.0\end{array}$ & $\begin{array}{l}0.0 \\
0.0 \\
0.0 \\
0.0 \\
0.0 \\
0.0 \\
1.2 \\
0.0 \\
0.0 \\
0.0 \\
0.0 \\
4.0\end{array}$ & $\begin{array}{l}0.0 \\
0.0 \\
0.0 \\
0.0 \\
0.7 \\
0.0 \\
1.2 \\
0.0 \\
0.0 \\
0.0 \\
0.0\end{array}$ & $\begin{array}{l}6 \\
30 \\
77 \\
0 \\
33 \\
34 \\
12 \\
30 \\
55 \\
7 \\
70 \\
0 \\
4 \\
4\end{array}$ & \\
\hline $\begin{array}{l}\text { NaR3SizO6 } \\
\text { NaTiALSTO6 } \\
\text { R2TiALI206 } \\
\text { R2R3AISIO6 }\end{array}$ & $\begin{array}{l}0.0021 \\
0.0000 \\
0.0050 \\
0.0203\end{array}$ & $\begin{array}{l}0.0014 \\
0.0000 \\
0.0053 \\
0.0238\end{array}$ & $\begin{array}{l}0.0022 \\
0.0000 \\
0.0059 \\
0.0285\end{array}$ & $\begin{array}{l}0.0022 \\
0.0000 \\
0.0050 \\
0.0277\end{array}$ & $\begin{array}{l}0.0007 \\
0.0000 \\
0.0070 \\
0.0311\end{array}$ & $\begin{array}{l}0.0022 \\
0.0000 \\
0.0059 \\
0.0238\end{array}$ & $\begin{array}{l}0.0000 \\
0.0000 \\
0.0058 \\
0.0154\end{array}$ & $\begin{array}{l}0.0007 \\
0.0000 \\
0.0050 \\
0.0140\end{array}$ & $\begin{array}{l}0.0014 \\
0.0000 \\
0.0045 \\
0.0173\end{array}$ & $\begin{array}{l}0.0021 \\
0.0000 \\
0.0050 \\
0.0144\end{array}$ & $\begin{array}{l}0.0 \\
0.0 \\
0.0 \\
0.0\end{array}$ & $\begin{array}{l}0.0016 \\
0.0000 \\
0.0061 \\
0.0282\end{array}$ & $\begin{array}{l}0.0 \\
0.0 \\
0.0 \\
0.0\end{array}$ & $\begin{array}{l}77 \\
50 \\
66\end{array}$ & & \\
\hline $\begin{array}{l}\text { Wo } \\
\text { En } \\
\text { Fs } \\
\text { Mg\# }\end{array}$ & $\begin{array}{r}0.0308 \\
0.6794 \\
0.2898 \\
70.1\end{array}$ & $\begin{array}{r}0.0267 \\
0.6562 \\
0.3171 \\
67.4\end{array}$ & $\begin{array}{r}0.0279 \\
0.6460 \\
0.3261 \\
66.5\end{array}$ & $\begin{array}{l}0.0277 \\
0.6566 \\
0.3157 \\
67.5\end{array}$ & $\begin{array}{l}0.0302 \\
0.6694 \\
0.3004 \\
69.0\end{array}$ & $\begin{array}{r}0.0252 \\
0.6481 \\
0.3267 \\
66.5\end{array}$ & $\begin{array}{r}0.0224 \\
0.6441 \\
0.3335 \\
65.9\end{array}$ & $\begin{array}{r}0.0218 \\
0.6151 \\
0.3632 \\
62.9\end{array}$ & $\begin{array}{r}0.0225 \\
0.6367 \\
0.3407 \\
65.1\end{array}$ & $\begin{array}{r}0.0258 \\
0.6586 \\
0.3156 \\
67.6\end{array}$ & $\begin{array}{r}0.0282 \\
0.6418 \\
0.3299 \\
66.0\end{array}$ & $\begin{array}{r}0.0262 \\
0.6500 \\
0.3238 \\
66.8\end{array}$ & $\begin{array}{r}0.0260 \\
0.6427 \\
0.3313 \\
66.0\end{array}$ & $\begin{array}{r}0.0242 \\
0.6132 \\
0.3626 \\
62.8\end{array}$ & $\begin{array}{r}0.0201 \\
0.6416 \\
0.3382 \\
65.5\end{array}$ & 0.3 \\
\hline
\end{tabular}

OPX 2 19-DeC-87 


\begin{tabular}{|c|c|c|c|c|c|c|c|c|c|c|c|c|c|c|c|c|}
\hline $\begin{array}{l}\text { Strat\# } \\
\text { Field\#\# } \\
\text { Grain } \\
\text { Anat\# }\end{array}$ & $\begin{array}{r}\text { Af- } 09 \\
85 \mathrm{cns09} \\
01 \mathrm{r} \\
200\end{array}$ & $\begin{array}{r}\text { AF-09 } \\
85 \mathrm{cns09} \\
02 \mathrm{c} \\
201\end{array}$ & $\begin{array}{r}\text { AF-09 } \\
85 c n s 09 \\
02 r \\
202\end{array}$ & $\begin{array}{r}A F-09 \\
85 \mathrm{cns} 09 \\
03 \mathrm{c} \\
203\end{array}$ & $\begin{array}{r}\text { Af-09 } \\
85 \text { cns09 } \\
03 r \\
204\end{array}$ & $\begin{array}{r}\text { Af }-09 \\
85 \mathrm{cns} 09 \\
04 \mathrm{c} \\
205\end{array}$ & $\begin{array}{r}A F-09 \\
85 \text { cns09 } \\
04 r \\
206\end{array}$ & $\begin{array}{r}\text { Af }-09 \\
85 \mathrm{cns09} \\
05 \mathrm{c} \\
208\end{array}$ & $\begin{array}{r}\text { Af-09 } \\
85 \text { cns09 } \\
05 r \\
209\end{array}$ & $\begin{array}{r}\text { SP-02 } \\
s p-r s 2 \\
011 \\
219\end{array}$ & $\begin{array}{r}s p-02 \\
s p-r s 2 \\
011 \\
220\end{array}$ & $\begin{array}{r}\mathbf{S P}-02 \\
\mathbf{s p}-\mathbf{r 8 2} \\
022 \\
221\end{array}$ & $\begin{array}{r}\text { SP-02 } \\
\text { sp-rs2 } \\
02 r \\
222\end{array}$ & $\begin{array}{r}\text { sp-02 } \\
\text { sp-rs2 } \\
03 c \\
223\end{array}$ & $\begin{array}{r}\text { Sp-02 } \\
s p-r 82 \\
03 r \\
224\end{array}$ & $\begin{array}{r}s p-02 \\
s p-r s 2 \\
04 c \\
225\end{array}$ \\
\hline $\begin{array}{l}\text { wtX } \\
\text { SiO2 } \\
\text { TiO2 } \\
\text { Al203 } \\
\text { fe203 } \\
\text { FeO } \\
\text { MnO } \\
\text { MgO } \\
\text { CaO } \\
\text { Na20 } \\
\text { Cr203 } \\
\text { tot } \\
\text { feo }\end{array}$ & $\begin{array}{r}53.04 \\
0.20 \\
0.69 \\
0.63 \\
21.39 \\
0.87 \\
22.47 \\
1.31 \\
0.01 \\
0.07 \\
100.68 \\
21.96\end{array}$ & $\begin{array}{r}53.74 \\
0.15 \\
0.89 \\
1.09 \\
20.31 \\
0.64 \\
23.83 \\
1.31 \\
0.02 \\
0.05 \\
102.03 \\
21.29\end{array}$ & $\begin{array}{r}54.34 \\
0.11 \\
0.45 \\
0.01 \\
21.48 \\
0.82 \\
23.05 \\
1.25 \\
0.02 \\
0.02 \\
101.55 \\
21.49\end{array}$ & $\begin{array}{r}53.38 \\
0.27 \\
0.87 \\
0.54 \\
20.54 \\
0.66 \\
23.20 \\
1.27 \\
0.03 \\
0.06 \\
100.81 \\
21.02\end{array}$ & $\begin{array}{r}53.45 \\
0.24 \\
0.99 \\
0.00 \\
20.46 \\
0.75 \\
22.58 \\
1.24 \\
0.01 \\
0.07 \\
99.79 \\
20.46\end{array}$ & $\begin{array}{r}53.67 \\
0.20 \\
0.70 \\
0.73 \\
19.96 \\
0.66 \\
23.90 \\
1.25 \\
0.03 \\
0.04 \\
101.14 \\
20.62\end{array}$ & $\begin{array}{r}54.24 \\
0.20 \\
0.76 \\
0.71 \\
19.27 \\
0.69 \\
24.45 \\
1.34 \\
0.02 \\
0.03 \\
101.71 \\
19.91\end{array}$ & $\begin{array}{r}53.77 \\
0.19 \\
0.75 \\
0.42 \\
21.53 \\
0.67 \\
22.90 \\
1.17 \\
0.03 \\
00.02 \\
101.45 \\
21.91\end{array}$ & $\begin{array}{r}53.92 \\
0.20 \\
0.47 \\
0.39 \\
21.17 \\
0.79 \\
23.13 \\
1.43 \\
0.02 \\
00.00 \\
101.52 \\
21.52\end{array}$ & $\begin{array}{r}53.44 \\
0.25 \\
0.83 \\
0.80 \\
21.08 \\
0.74 \\
23.40 \\
1.11 \\
0.02 \\
00.05 \\
101.72 \\
21.80\end{array}$ & $\begin{array}{r}53.78 \\
0.21 \\
0.79 \\
0.79 \\
20.82 \\
0.78 \\
23.75 \\
1.02 \\
0.01 \\
0.05 \\
102.00 \\
21.53\end{array}$ & $\begin{array}{r}54.32 \\
0.23 \\
0.66 \\
0.00 \\
21.30 \\
0.73 \\
22.74 \\
1.34 \\
0.01 \\
00.02 \\
101 . .35 \\
21.30\end{array}$ & $\begin{array}{r}53.68 \\
0.18 \\
0.76 \\
0.43 \\
21.04 \\
0.70 \\
22.97 \\
1.34 \\
0.03 \\
00.00 \\
101.13 \\
21.43\end{array}$ & $\begin{array}{r}52.56 \\
0.18 \\
0.78 \\
0.93 \\
20.24 \\
0.70 \\
22.70 \\
2.59 \\
0.03 \\
0.01 \\
100.72 \\
21.08\end{array}$ & $\begin{array}{r}52.85 \\
0.27 \\
0.88 \\
0.84 \\
20.85 \\
0.67 \\
22.98 \\
1.34 \\
0.01 \\
00.02 \\
100.71 \\
21.61\end{array}$ & $\begin{array}{r}53.66 \\
0.20 \\
0.84 \\
0.29 \\
22.02 \\
0.64 \\
22.50 \\
1.23 \\
0.03 \\
0.03 \\
101.44 \\
22.28\end{array}$ \\
\hline $\begin{array}{l}\text { atoms } / 60 \\
\text { Si } \\
\text { Ii } \\
\text { Al t } \\
\mathrm{Al}_{0} \\
\mathrm{Fe}+ \\
\mathrm{Fe2+} \\
\mathrm{Mn} \\
\mathrm{Mg} \\
\mathrm{Ca} \\
\mathrm{Ma} \\
\mathrm{Mi} \\
\mathrm{Cr} \\
\text { tot }\end{array}$ & $\begin{array}{l}1.9682 \\
0.0056 \\
0.0302 \\
0.0000 \\
0.0177 \\
0.0638 \\
0.0273 \\
1.2427 \\
0.0521 \\
0.0007 \\
0.0000 \\
0.0021 \\
4.0104\end{array}$ & $\begin{array}{l}1.9586 \\
0.0041 \\
0.0382 \\
0.0000 \\
0.0300 \\
0.6190 \\
0.0198 \\
1.2944 \\
0.0512 \\
0.0014 \\
0.0000 \\
0.0014 \\
4.0181\end{array}$ & $\begin{array}{l}1.9875 \\
0.0030 \\
0.0125 \\
0.0069 \\
0.0003 \\
0.6570 \\
0.0254 \\
1.2565 \\
0.0490 \\
0.0014 \\
0.0000 \\
0.0006 \\
4.0002\end{array}$ & $\begin{array}{l}1.9664 \\
0.0075 \\
0.0336 \\
0.0041 \\
0.0149 \\
0.6326 \\
0.0206 \\
1.2737 \\
0.0501 \\
0.0021 \\
0.0000 \\
0.0017 \\
4.0075\end{array}$ & $\begin{array}{l}1.9817 \\
0.0067 \\
0.0183 \\
0.0250 \\
0.0000 \\
0.03444 \\
0.0236 \\
1.2477 \\
0.0493 \\
0.0007 \\
0.0000 \\
0.0021 \\
3.9893\end{array}$ & $\begin{array}{l}1.9669 \\
0.0055 \\
0.0302 \\
0.0000 \\
0.0202 \\
0.6118 \\
0.0205 \\
1.3054 \\
0.0491 \\
0.0021 \\
0.0000 \\
0.0012 \\
4.0129\end{array}$ & $\begin{array}{l}1.9689 \\
0.0055 \\
0.0311 \\
0.0014 \\
0.0193 \\
0.5851 \\
0.0212 \\
1.3227 \\
0.0521 \\
0.0014 \\
0.0000 \\
0.0009 \\
4.0096\end{array}$ & $\begin{array}{l}1.9735 \\
0.0052 \\
0.0265 \\
0.0059 \\
0.0117 \\
0.6609 \\
0.0208 \\
1.2526 \\
0.0460 \\
0.0021 \\
0.0000 \\
0.0006 \\
4.0058\end{array}$ & $\begin{array}{l}1.9768 \\
0.0055 \\
0.0203 \\
0.0000 \\
0.0107 \\
0.6491 \\
0.0245 \\
1.2638 \\
0.0562 \\
0.0014 \\
0.0000 \\
0.0000 \\
4.0083\end{array}$ & $\begin{array}{l}1.9584 \\
0.0069 \\
0.0359 \\
0.0000 \\
0.0221 \\
0.6461 \\
0.0230 \\
1.2780 \\
0.0436 \\
0.0014 \\
0.0000 \\
0.0014 \\
4.0168\end{array}$ & $\begin{array}{l}1.9616 \\
0.0058 \\
0.0340 \\
0.0000 \\
0.0217 \\
0.6351 \\
0.0241 \\
1.2910 \\
0.0399 \\
0.0007 \\
0.0000 \\
0.0014 \\
4.0153\end{array}$ & $\begin{array}{l}1.9880 \\
0.0063 \\
0.0120 \\
0.0165 \\
0.0000 \\
0.6519 \\
0.0226 \\
1.2403 \\
0.0525 \\
0.0007 \\
0.0000 \\
0.0006 \\
3.9915\end{array}$ & $\begin{array}{l}1.9737 \\
0.0050 \\
0.0263 \\
0.0066 \\
0.0119 \\
0.6471 \\
0.0218 \\
1.2587 \\
0.0528 \\
0.0021 \\
0.0000\end{array}$ & $\begin{array}{l}10 \\
50 \\
41 \\
00 \\
59 \\
35 \\
20 \\
58 \\
30 \\
22 \\
00 \\
03 \\
78\end{array}$ & $\begin{array}{l}72 \\
75 \\
84 \\
00 \\
35 \\
58 \\
10 \\
83 \\
32 \\
07 \\
00 \\
06 \\
62\end{array}$ & \\
\hline 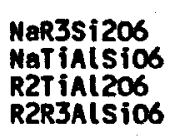 & $\begin{array}{l}0.0007 \\
0.0000 \\
0.0056 \\
0.0190\end{array}$ & $\begin{array}{l}0.0014 \\
0.0000 \\
0.0041 \\
0.0300\end{array}$ & $\begin{array}{l}0.0014 \\
0.0000 \\
0.0030 \\
0.0064\end{array}$ & $\begin{array}{l}0.0021 \\
0.0000 \\
0.0075 \\
0.0187\end{array}$ & $\begin{array}{l}0.0007 \\
0.0000 \\
0.0067 \\
0.0049\end{array}$ & $\begin{array}{l}0.0021 \\
0.0000 \\
0.0055 \\
0.0192\end{array}$ & $\begin{array}{l}0.0014 \\
0.0000 \\
0.0055 \\
0.0202\end{array}$ & $\begin{array}{l}0.0021 \\
0.0000 \\
0.0052 \\
0.0160\end{array}$ & $\begin{array}{l}0.0014 \\
0.0000 \\
0.0055 \\
0.0093\end{array}$ & $\begin{array}{l}0.0014 \\
0.0000 \\
0.0069 \\
0.0221\end{array}$ & $\begin{array}{l}0.0 \\
0.0 \\
0.0\end{array}$ & & & & & \\
\hline $\begin{array}{l}\text { Ho } \\
\text { En } \\
\text { Fs } \\
\text { Mg\# }\end{array}$ & $\begin{array}{l}0.0269 \\
0.6343 \\
0.3388 \\
65.2\end{array}$ & $\begin{array}{r}0.0265 \\
0.6586 \\
0.3149 \\
67.7\end{array}$ & $\begin{array}{l}0.0251 \\
0.6402 \\
0.3348 \\
65.7\end{array}$ & $\begin{array}{l}0.0260 \\
0.6508 \\
0.3232 \\
66.8\end{array}$ & $\begin{array}{r}0.0257 \\
0.645 \\
0.3284 \\
66.3\end{array}$ & $\begin{array}{l}0.0253 \\
0.6637 \\
0.3119 \\
68.1\end{array}$ & $\begin{array}{l}0.0269 \\
0.6746 \\
0.2984 \\
69.3\end{array}$ & $\begin{array}{l}0.0237 \\
0.0391 \\
0.3372 \\
65.5\end{array}$ & $\begin{array}{l}0.0287 \\
0.6477 \\
0.3296 \\
66.1\end{array}$ & $\begin{array}{l}0.0225 \\
0.6493 \\
0.3282 \\
66.4\end{array}$ & $\begin{array}{l}0.0206 \\
0.6565 \\
0.3229 \\
67.0\end{array}$ & $\begin{array}{l}0.0271 \\
0.6377 \\
0.3352 \\
65.5\end{array}$ & $\begin{array}{l}0.0273 \\
0.6425 \\
0.3303 \\
66.0\end{array}$ & $\begin{array}{l}36 \\
4 \\
60 \\
6\end{array}$ & $\begin{array}{l}0.0275 \\
0.6444 \\
0.3281 \\
66.3\end{array}$ & \\
\hline
\end{tabular}




\begin{tabular}{|c|c|c|c|c|c|c|c|c|c|c|c|c|c|c|c|c|}
\hline $\begin{array}{l}\text { Strat\# } \\
\text { Field\# } \\
\text { Grain } \\
\text { Anal\# }\end{array}$ & $\begin{array}{r}\text { SP-02 } \\
\text { sp-rs2 } \\
04 r \\
226\end{array}$ & $\begin{array}{r}\text { SP-02 } \\
\text { sp-rs2 } \\
05 c \\
227\end{array}$ & $\begin{array}{r}\text { SP-02 } \\
\mathbf{s p - r s 2} \\
05 c \\
230\end{array}$ & $\begin{array}{r}s p-02 \\
s p-r s 2 \\
05 r \\
228 \\
228\end{array}$ & $\begin{array}{r}\text { SP-02 } \\
\text { sp-rs2 } \\
6 p c .05 c \\
229\end{array}$ & $\begin{array}{r}\text { PF-38 } \\
85 \mathrm{cns38} \\
01 \mathrm{lc} \\
155\end{array}$ & $\begin{array}{r}\text { PF-38 } \\
85 \mathrm{cns} 38 \\
01 r \\
156\end{array}$ & $\begin{array}{r}P F-38 \\
85 c n s 38 \\
02 c \\
157\end{array}$ & $\begin{array}{r}\text { PF-38 } \\
\text { 85cns38 } \\
02 r \\
158\end{array}$ & $\begin{array}{r}\text { PF-38 } \\
85 \mathrm{cns38} \\
03 c \\
159\end{array}$ & $\begin{array}{r}\text { PF-38 } \\
85 \mathrm{cns} 38 \\
035 \\
160\end{array}$ & $\begin{array}{r}\text { PF-38 } \\
85 \mathrm{cns38} \\
04 c \\
161\end{array}$ & $\begin{array}{r}\text { PF-38 } \\
85 \mathrm{cns38} \\
04 r \\
162\end{array}$ & $\begin{array}{r}\text { PF-38 } \\
85 \mathrm{cns38} \\
05 c . c 1 c \\
143\end{array}$ & $\begin{array}{r}\text { PF-38 } \\
85 \text { cns38 } \\
\text { P. } 06 c \\
149\end{array}$ & $\begin{array}{r}\text { PCP-B06 } \\
85 \text { Cns28 } \\
\text { P. } 011 \\
291\end{array}$ \\
\hline 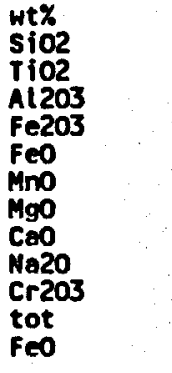 & $\begin{array}{r}54.22 \\
0.24 \\
0.84 \\
0.21 \\
20.12 \\
0.73 \\
23.72 \\
1.43 \\
0.04 \\
0.05 \\
101.60 \\
20.31\end{array}$ & $\begin{array}{r}53.09 \\
0.11 \\
0.53 \\
0.60 \\
23.24 \\
0.91 \\
22.03 \\
0.62 \\
0.02 \\
0.06 \\
101.21 \\
23.78\end{array}$ & $\begin{array}{r}53.27 \\
0.07 \\
0.59 \\
0.38 \\
23.59 \\
0.91 \\
21.67 \\
0.63 \\
0.00 \\
0.00 \\
101.11 \\
23.93\end{array}$ & $\begin{array}{r}54.09 \\
0.08 \\
0.41 \\
0.46 \\
21.42 \\
0.73 \\
23.46 \\
1.00 \\
0.00 \\
0.02 \\
101.68 \\
21.84\end{array}$ & $\begin{array}{r}53.42 \\
0.09 \\
0.54 \\
0.00 \\
23.68 \\
0.87 \\
21.59 \\
0.64 \\
0.01 \\
0.03 \\
100.87 \\
23.68\end{array}$ & $\begin{array}{r}53.39 \\
0.41 \\
1.72 \\
0.38 \\
18.17 \\
0.37 \\
24.64 \\
1.36 \\
0.04 \\
\mathrm{na} \\
100.48 \\
18.54\end{array}$ & $\begin{array}{r}52.60 \\
0.25 \\
1.89 \\
1.35 \\
16.82 \\
0.34 \\
25.16 \\
1.24 \\
0.03 \\
\text { na } \\
99.68 \\
18.03\end{array}$ & $\begin{array}{r}52.29 \\
0.28 \\
1.25 \\
1.06 \\
18.33 \\
0.35 \\
23.98 \\
1.36 \\
0.02 \\
\text { na } \\
98.93 \\
19.29\end{array}$ & $\begin{array}{r}53.61 \\
0.33 \\
1.25 \\
0.00 \\
19.26 \\
0.39 \\
23.97 \\
1.32 \\
0.03 \\
\text { na } \\
100.16 \\
19.26\end{array}$ & $\begin{array}{r}53.88 \\
0.20 \\
2.21 \\
1.06 \\
14.67 \\
0.30 \\
27.43 \\
0.89 \\
0.02 \\
10 \\
100.66 \\
15.62\end{array}$ & $\begin{array}{r}52.38 \\
0.26 \\
1.58 \\
1.39 \\
17.39 \\
0.39 \\
24.46 \\
1.51 \\
0.04 \\
99 \\
1.40 \\
18.64\end{array}$ & $\begin{array}{r}53.66 \\
0.25 \\
1.44 \\
1.16 \\
19.08 \\
0.42 \\
24.50 \\
1.25 \\
0.03 \\
n 0 \\
101.80 \\
20.13\end{array}$ & $\begin{array}{r}53.84 \\
0.23 \\
1.39 \\
0.89 \\
18.05 \\
0.39 \\
25.08 \\
1.33 \\
0.03 \\
101.00 \\
18.83\end{array}$ & $\begin{array}{r}53.84 \\
0.25 \\
1.40 \\
0.45 \\
18.22 \\
0.38 \\
24.81 \\
1.41 \\
0.04 \\
\text { na } \\
100.80 \\
18.62\end{array}$ & $\begin{array}{r}53.31 \\
0.20 \\
0.99 \\
1.09 \\
17.99 \\
0.39 \\
24.68 \\
1.57 \\
0.05 \\
\text { na } \\
100.07 \\
18.77\end{array}$ & $\begin{array}{r}53.97 \\
0.24 \\
1.23 \\
0.45 \\
16.68 \\
0.41 \\
25.46 \\
1.83 \\
0.03 \\
0.07 \\
100.38 \\
17.09\end{array}$ \\
\hline $\begin{array}{l}\text { atoms } / 60 \\
\text { Si } \\
\text { Ii } \\
\text { Al t } \\
\text { Al } \\
\text { Fest } \\
\text { Fe2t } \\
\text { Mn } \\
\text { Mg } \\
\text { Ca } \\
\text { Ma } \\
\text { Mi } \\
\text { Cr } \\
\text { tot }\end{array}$ & $\begin{array}{l}1.9732 \\
0.0066 \\
0.0268 \\
0.0092 \\
0.0059 \\
0.6123 \\
0.0225 \\
1.2865 \\
0.0558 \\
0.0028 \\
0.0000 \\
0.0014 \\
4.0029\end{array}$ & $\begin{array}{l}1.9720 \\
0.0031 \\
0.0232 \\
0.0000 \\
0.0167 \\
0.7220 \\
0.0286 \\
1.2195 \\
0.0247 \\
0.0014 \\
0.0000 \\
0.0018 \\
4.0131\end{array}$ & $\begin{array}{l}1.9798 \\
0.0020 \\
0.0202 \\
0.0056 \\
0.0107 \\
0.7331 \\
0.0286 \\
1.2003 \\
0.0251 \\
0.0000 \\
0.0000 \\
0.0000 \\
4.0054\end{array}$ & $\begin{array}{l}1.9793 \\
0.0022 \\
0.0177 \\
0.0000 \\
0.0127 \\
0.6557 \\
0.0226 \\
1.2794 \\
0.0392 \\
0.0000 \\
0.0000 \\
0.0006\end{array}$ & $\begin{array}{l}1.9861 \\
0.0025 \\
0.0139 \\
0.0098 \\
0.0000 \\
0.7363 \\
0.0274 \\
1.1963 \\
0.0255 \\
0.0007 \\
0.0000 \\
0.0009 \\
3.9994\end{array}$ & $\begin{array}{l}1.9479 \\
0.0113 \\
0.0521 \\
0.0219 \\
0.0104 \\
0.5544 \\
0.0114 \\
1.3398 \\
0.0532 \\
0.0028 \\
0.0000 \\
0.0000 \\
4.0052\end{array}$ & $\begin{array}{l}1.9345 \\
0.0069 \\
0.0655 \\
0.0165 \\
0.0373 \\
0.5173 \\
0.0106 \\
1.3791 \\
0.0489 \\
0.0021 \\
0.0000 \\
0.0000 \\
4.0186\end{array}$ & $\begin{array}{l}1.9504 \\
0.0079 \\
0.0496 \\
0.0054 \\
0.0299 \\
0.5719 \\
0.0111 \\
1.3330 \\
0.0544 \\
0.0014 \\
0.0000 \\
0.0000 \\
4.0149\end{array}$ & $\begin{array}{l}1.9670 \\
0.0091 \\
0.0330 \\
0.0210 \\
0.0000 \\
0.5910 \\
0.0121 \\
1.3107 \\
0.0519 \\
0.0021 \\
0.0000 \\
0.0000 \\
3.9980\end{array}$ & $\begin{array}{l}1.9342 \\
0.0054 \\
0.0658 \\
0.0277 \\
0.0287 \\
0.4403 \\
0.0091 \\
1.4675 \\
0.0342 \\
0.0014 \\
0.0000 \\
0.0000 \\
4.0143\end{array}$ & $\begin{array}{l}1.9403 \\
0.0072 \\
0.0597 \\
0.0093 \\
0.0388 \\
0.5387 \\
0.0122 \\
1.3503 \\
0.0599 \\
0.0029 \\
0.0000 \\
0.0000 \\
4.0194\end{array}$ & $\begin{array}{l}1.9476 \\
0.0068 \\
0.0524 \\
0.0092 \\
0.0317 \\
0.5793 \\
0.0129 \\
1.3252 \\
0.0486 \\
0.0021 \\
0.0000 \\
0.0000 \\
4.0159\end{array}$ & $\begin{array}{l}1.9530 \\
0.0063 \\
0.0470 \\
0.0124 \\
0.0242 \\
0.5476 \\
0.0120 \\
1.3558 \\
0.0517 \\
0.0021 \\
0.0000 \\
0.0000 \\
4.0121\end{array}$ & $\begin{array}{l}584 \\
068 \\
4416 \\
184 \\
123 \\
541 \\
117 \\
449 \\
550 \\
028 \\
000 \\
1000\end{array}$ & $\begin{array}{l}98 \\
55 \\
02 \\
27 \\
00 \\
71 \\
21 \\
22 \\
18 \\
36 \\
00 \\
00 \\
50\end{array}$ & 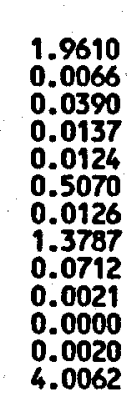 \\
\hline $\begin{array}{l}\text { NaR3SizOS } \\
\text { NaTIALISIO6 } \\
\text { R2TIALI206 } \\
\text { R2R3ALSIO6 }\end{array}$ & $\begin{array}{l}0.0028 \\
0.0000 \\
0.0066 \\
0.0137\end{array}$ & $\begin{array}{l}0.0014 \\
0.0000 \\
0.0031 \\
0.0171\end{array}$ & $\begin{array}{l}0.0000 \\
0.0000 \\
0.0020 \\
0.0163\end{array}$ & $\begin{array}{l}0.0000 \\
0.0000 \\
0.0022\end{array}$ & $\begin{array}{l}0.0007 \\
0.0000 \\
0.0025 \\
0.0088\end{array}$ & $\begin{array}{l}0.0 \\
0.0 \\
0.0 \\
0.0\end{array}$ & $\begin{array}{l}0.0021 \\
0.0000 \\
0.0069 \\
0.0516\end{array}$ & $\begin{array}{l}.0014 \\
.0000 \\
.0079 \\
.0338\end{array}$ & $\begin{array}{l}0.0 \\
0 . \\
0 .\end{array}$ & $\begin{array}{l}14 \\
00 \\
54 \\
50\end{array}$ & $\begin{array}{l}0.8 \\
0.0 \\
0.0 \\
0.0\end{array}$ & & $\begin{array}{l}21 \\
63 \\
65 \\
45\end{array}$ & & & \\
\hline $\begin{array}{l}\text { Ho } \\
\text { En } \\
\text { Fs } \\
\text { Mg\# }\end{array}$ & $\begin{array}{r}0.0288 \\
0.6580 \\
0.3132 \\
67.8\end{array}$ & $\begin{array}{l}0.0127 \\
0.6202 \\
0.3672 \\
62.8\end{array}$ & $\begin{array}{r}0.0129 \\
0.6128 \\
0.3743 \\
62.1\end{array}$ & $\begin{array}{r}0.0200 \\
0.6479 \\
0.3321 \\
66.1\end{array}$ & $\begin{array}{r}0.0131 \\
0.6109 \\
0.3760 \\
61.9\end{array}$ & $\begin{array}{l}0.0279 \\
0.6876 \\
0.2845 \\
70.7\end{array}$ & $\begin{array}{l}0.0259 \\
0.7084 \\
0.2657 \\
72.7\end{array}$ & $\begin{array}{l}0.0283 \\
0.6800 \\
0.2917 \\
70.0\end{array}$ & $\begin{array}{l}0.0269 \\
0.6707 \\
0.3024 \\
68.9\end{array}$ & $\begin{array}{l}0.0182 \\
0.7552 \\
0.2266 \\
76.9\end{array}$ & $\begin{array}{l}0.0316 \\
0.6922 \\
0.2762 \\
71.5\end{array}$ & $\begin{array}{l}0.0255 \\
0.6781 \\
0.2964 \\
69.6\end{array}$ & $\begin{array}{l}0.0270 \\
0.6931 \\
0.2799 \\
71.2\end{array}$ & & $\begin{array}{l}0.0321 \\
0.6891 \\
0.2788 \\
71.2\end{array}$ & $\begin{array}{l}0.0370 \\
0.7041 \\
0.2589 \\
73.1\end{array}$ \\
\hline
\end{tabular}




\begin{tabular}{|c|c|c|c|c|c|c|c|c|c|c|c|c|c|c|c|c|}
\hline $\begin{array}{l}\text { Strat\# } \\
\text { Field\# } \\
\text { Grain }\end{array}$ & $\begin{array}{r}\text { PCP-BD6 } \\
\text { 85Cns28 } \\
\text { P.01r1 } \\
292\end{array}$ & $\begin{array}{r}\text { PCP-BD6 } \\
85 c n s 28 \\
\text { P.01r2 } \\
293\end{array}$ & $\begin{array}{r}\text { PCP-B06 } \\
85 \text { cns28 } \\
\text { P.02C } \\
294\end{array}$ & $\begin{array}{r}\text { PCP-B06 } \\
85 \text { Cns28 } \\
\text { P.02r } \\
295\end{array}$ & $\begin{array}{r}\text { PCP-AOS } \\
85 \text { Cns52 } \\
01 c \\
80\end{array}$ & $\begin{array}{r}\text { PCP-A03 } \\
85 \text { ens52 } \\
015 \\
81 .\end{array}$ & $\begin{array}{r}P C P-A 03 \\
85 \mathrm{Cns52} \\
02 \mathrm{C} \\
83\end{array}$ & $\begin{array}{r}\text { PCP-A03 } \\
85 \text { Cns52 } \\
02 r \\
84\end{array}$ & $\begin{array}{r}P C P-A 03 \\
85 \text { Cns52 } \\
03 c \\
85\end{array}$ & $\begin{array}{r}\text { PCP-A03 } \\
85 \text { ens52 } \\
03 r \\
86\end{array}$ & $\begin{array}{r}\text { PCP-A03 } \\
85 \text { Cns52 } \\
04 c \\
89\end{array}$ & $\begin{array}{r}\text { PCP- } 103 \\
85 \text { cns52 } \\
04 r \\
90\end{array}$ & $\begin{array}{r}\text { PCP- } 103 \\
85 \text { Cns52 } \\
05 C \\
91\end{array}$ & $\begin{array}{r}P C P-103 \\
85 \text { Cns52 } \\
05 r \\
92\end{array}$ & & $\begin{array}{r}P C P-A 05 \\
85 \text { C } 1550 \\
01 C \\
102\end{array}$ \\
\hline 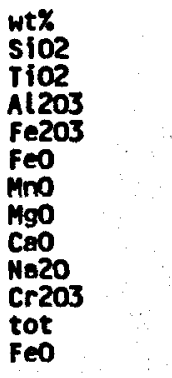 & $\begin{array}{r}54.75 \\
0.31 \\
1.24 \\
0.26 \\
17.13 \\
0.35 \\
25.78 \\
1.76 \\
0.04 \\
0.01 \\
101.03 \\
17.36\end{array}$ & $\begin{array}{r}54.64 \\
0.34 \\
1.19 \\
0.00 \\
17.32 \\
0.34 \\
25.25 \\
1.74 \\
0.04 \\
0.03 \\
100.89 \\
17.32\end{array}$ & $\begin{array}{r}53.20 \\
0.34 \\
1.73 \\
0.60 \\
16.85 \\
0.30 \\
25.08 \\
1.68 \\
0.04 \\
0.01 \\
99.83 \\
17.39\end{array}$ & $\begin{array}{r}53.85 \\
0.28 \\
1.53 \\
0.00 \\
17.37 \\
0.35 \\
24.93 \\
1.69 \\
0.04 \\
00.03 \\
100.07 \\
17.37\end{array}$ & $\begin{array}{r}53.03 \\
0.35 \\
1.50 \\
0.67 \\
16.07 \\
0.41 \\
25.51 \\
1.55 \\
0.02 \\
99.11 \\
9.07 \\
16.67\end{array}$ & $\begin{array}{r}53.00 \\
0.53 \\
1.70 \\
0.77 \\
15.26 \\
0.35 \\
25.80 \\
1.96 \\
0.02 \\
99.79 \\
99.39 \\
15.95\end{array}$ & $\begin{array}{r}53.01 \\
0.22 \\
2.40 \\
1.68 \\
11.65 \\
0.30 \\
28.33 \\
1.34 \\
0.04 \\
\text { na } \\
98.97 \\
13.16\end{array}$ & $\begin{array}{r}53.84 \\
0.23 \\
2.19 \\
1.15 \\
11.91 \\
0.28 \\
28.61 \\
1.39 \\
0.03 \\
\text { na } \\
99.64 \\
12.95\end{array}$ & $\begin{array}{r}53.70 \\
0.26 \\
1.49 \\
0.34 \\
13.75 \\
0.34 \\
27.20 \\
1.48 \\
0.03 \\
98.58 \\
98.58 \\
14.05\end{array}$ & $\begin{array}{r}53.77 \\
0.28 \\
1.21 \\
1.12 \\
14.63 \\
0.34 \\
26.89 \\
1.54 \\
0.04 \\
\text { na } \\
99.81 \\
15.63\end{array}$ & $\begin{array}{r}54.51 \\
0.11 \\
1.72 \\
0.00 \\
12.21 \\
0.32 \\
28.52 \\
1.38 \\
0.02 \\
98.79 \\
12.79 \\
12.21\end{array}$ & $\begin{array}{r}54.25 \\
0.14 \\
1.73 \\
0.78 \\
12.32 \\
0.31 \\
28.50 \\
1.36 \\
0.04 \\
99.43\end{array}$ & $\begin{array}{r}52.50 \\
0.34 \\
1.83 \\
1.09 \\
14.06 \\
0.37 \\
25.88 \\
1.63 \\
0.07 \\
98.37 \\
98.37 \\
15.64\end{array}$ & $\begin{array}{r}53.70 \\
0.30 \\
0.93 \\
0.46 \\
15.18 \\
0.39 \\
26.25 \\
1.71 \\
0.03 \\
00 \\
00\end{array}$ & $\begin{array}{r}52.70 \\
0.31 \\
1.83 \\
0.85 \\
14.79 \\
0.38 \\
25.94 \\
1.70 \\
0.02 \\
98 \\
98.53\end{array}$ & $\begin{array}{r}54.65 \\
0.63 \\
4.43 \\
0.00 \\
19.98 \\
0.30 \\
16.05 \\
2.04 \\
0.92 \\
n \text { no } \\
99.00 \\
19.98\end{array}$ \\
\hline 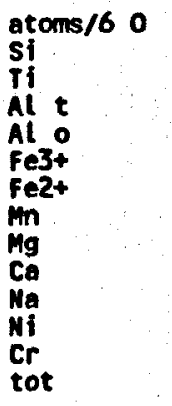 & $\begin{array}{l}1.9632 \\
0.0084 \\
0.0368 \\
0.0156 \\
0.0070 \\
0.5136 \\
0.0106 \\
1.3776 \\
0.0676 \\
0.0028 \\
0.0000 \\
0.0003 \\
4.0035\end{array}$ & $\begin{array}{l}1.9721 \\
0.0092 \\
0.0279 \\
0.0227 \\
0.0000 \\
0.5228 \\
0.0104 \\
1.3582 \\
0.0673 \\
0.0028 \\
0.0000 \\
0.0009 \\
3.9943\end{array}$ & $\begin{array}{l}1.9464 \\
0.0094 \\
0.0536 \\
0.0210 \\
0.0165 \\
0.5156 \\
0.0093 \\
. .3675 \\
0.0659 \\
0.0028 \\
0.0000 \\
0.0003 \\
4.0082\end{array}$ & $\begin{array}{l}1.9619 \\
0.0077 \\
0.0381 \\
0.0276 \\
0.0000 \\
0.5293 \\
0.0108 \\
1.3536 \\
0.0660 \\
0.0028 \\
0.0000 \\
0.0009 \\
3.9986\end{array}$ & $\begin{array}{l}1.9493 \\
0.0097 \\
0.0507 \\
0.0143 \\
0.0184 \\
0.4940 \\
0.0128 \\
1.3975 \\
0.0617 \\
0.0014 \\
0.0000 \\
0.0000 \\
4.0092\end{array}$ & $\begin{array}{l}1.9389 \\
0.0146 \\
0.0611 \\
0.0122 \\
0.0211 \\
0.4669 \\
0.0108 \\
1.4066 \\
0.0768 \\
0.0014 \\
0.0000 \\
0.0000 \\
4.0106\end{array}$ & $\begin{array}{l}1.9212 \\
0.0000 \\
0.0788 \\
0.0238 \\
0.0458 \\
0.3531 \\
0.0092 \\
1.0502 \\
0.0520 \\
0.0028 \\
0.0000 \\
0.0000 \\
4.0229\end{array}$ & $\begin{array}{l}1.9329 \\
0.0062 \\
0.0671 \\
0.0256 \\
0.0311 \\
0.3577 \\
0.0085 \\
1.53308 \\
0.0535 \\
0.0021 \\
0.0000 \\
0.0000 \\
4.0155\end{array}$ & $\begin{array}{l}0.0 \\
0.0 \\
0.0 \\
0.0 \\
0.4 \\
0.0 \\
1.4 \\
0.0 \\
0.0 \\
0.0 \\
0.0 \\
4.0\end{array}$ & $\begin{array}{l}.9526 \\
.0076 \\
.0474 \\
.0044 \\
.0305 \\
.4442 \\
.0105 \\
.4553 \\
.0599 \\
.0028 \\
.0000 \\
.0000 \\
.0152\end{array}$ & $\begin{array}{l}0.8 \\
0.0 \\
0.0 \\
0.0 \\
0.7 \\
0.0 \\
1.0 \\
0.0 \\
0.0 \\
0.8 \\
0.8 \\
3.9\end{array}$ & $\begin{array}{l}14 \\
8 \\
67 \\
7 \\
2 \\
3 \\
4 \\
0 \\
4 \\
8 \\
0 \\
0 \\
10 \\
16\end{array}$ & $\begin{array}{l}32 \\
74 \\
18 \\
88 \\
02 \\
27 \\
16 \\
39 \\
35 \\
50 \\
50 \\
00\end{array}$ & & & \\
\hline 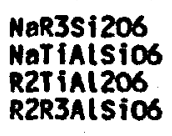 & $\begin{array}{l}0.0028 \\
0.0000 \\
0.0084 \\
0.0201\end{array}$ & $\begin{array}{l}0.0028 \\
0.0000 \\
0.0002\end{array}$ & $\begin{array}{l}0.0028 \\
0.0000 \\
0.0094 \\
0.0349\end{array}$ & $\begin{array}{l}0.0028 \\
0.0000 \\
0.0077 \\
0.0228\end{array}$ & $\begin{array}{l}0.0 \\
0.0 \\
0.0 \\
0.0\end{array}$ & $\begin{array}{l}14 \\
30 \\
19\end{array}$ & $\begin{array}{l}28 \\
00 \\
60 \\
68\end{array}$ & & & & & & & & & \\
\hline Wo & $\begin{array}{r}0.0350 \\
0.7029 \\
0.2620 \\
72.8\end{array}$ & $\begin{array}{l}0.0349 \\
0.6969 \\
0.2682 \\
72.2\end{array}$ & $\begin{array}{l}0.0346 \\
0.7011 \\
0.2644 \\
72.6\end{array}$ & $\begin{array}{l}0.0344 \\
0.6942 \\
0.2714 \\
71.9\end{array}$ & $\begin{array}{l}0.0319 \\
0.7152 \\
0.2528 \\
73.9\end{array}$ & $\begin{array}{l}0.0404 \\
0.7205 \\
0.2391 \\
\frac{75.1}{75.1}\end{array}$ & $\begin{array}{l}0.0279 \\
0.02798 \\
0.1822 \\
81.3\end{array}$ & $\begin{array}{l}0.7875 \\
0.1840 \\
81.1\end{array}$ & $\begin{array}{l}0.0301 \\
0.7556 \\
0.2143 \\
77.9\end{array}$ & $\begin{array}{l}0.0312 \\
0.7422 \\
0.2266 \\
76.6\end{array}$ & $\begin{array}{l}0.0278 \\
0.7839 \\
0.1823 \\
80.6\end{array}$ & $\begin{array}{l}0.0275 \\
0.7827 \\
0.1898 \\
80.5\end{array}$ & $\begin{array}{l}41 \\
29 \\
30 \\
9\end{array}$ & & & \\
\hline
\end{tabular}




\begin{tabular}{|c|c|c|c|c|c|c|c|c|c|c|c|c|c|c|c|c|}
\hline $\begin{array}{l}\text { Strat\# } \\
\text { Fielof }\end{array}$ & $\begin{array}{r}\text { PCP-105 } \\
85 \text { ens50 } \\
01 r \\
103\end{array}$ & $\begin{array}{r}\text { PCP-A05 } \\
85 \mathrm{ens50} \\
02 \mathrm{C} \\
106\end{array}$ & $\begin{array}{r}\text { PCP-A05 } \\
85 \text { ens50 } \\
02 r \\
107\end{array}$ & $\begin{array}{r}\text { PCP-A05 } \\
85 \mathrm{Cns50} \\
03 \mathrm{C} \\
108\end{array}$ & $\begin{array}{r}P C P-105 \\
85 \text { ens50 } \\
03 r \\
109\end{array}$ & $\begin{array}{r}\text { PCP-A05 } \\
85 \text { ens50 } \\
04 c \\
110\end{array}$ & $\begin{array}{r}\text { PCP-A05 } \\
85 \text { ens50 } \\
04 r \\
111\end{array}$ & $\begin{array}{r}\text { PCP- } 105 \\
85 \text { Cns50 } \\
05 c \\
112\end{array}$ & $\begin{array}{r}\text { PCP-A05 } \\
\text { 85cns50 } \\
05 \mathrm{r} \\
113\end{array}$ & $\begin{array}{r}\text { PCP-A05 } \\
85 C n s 50 \\
\text { P1.06C } \\
96\end{array}$ & $\begin{array}{r}\text { PCP-A05 } \\
85 \text { Cns50 } \\
\text { P1.07c } \\
97\end{array}$ & $\begin{array}{r}\text { PCP-A05 } \\
85 \text { CNS50 } \\
\text { P1.08C } \\
98\end{array}$ & $\begin{array}{r}\text { PCP-A05 } \\
85 C \text { CN50 } \\
\text { P1.09r } \\
99\end{array}$ & $\begin{array}{r}\text { CP-07 } \\
85 \mathrm{cns} 60 \\
01 \mathrm{1c} \\
134\end{array}$ & $\begin{array}{r}\text { CP-07 } \\
85 \mathrm{cns60} \\
01 \mathrm{1} \\
135\end{array}$ & $\begin{array}{r}\text { CP-07 } \\
85 \mathrm{ens} 60 \\
02 \mathrm{C} \\
136\end{array}$ \\
\hline 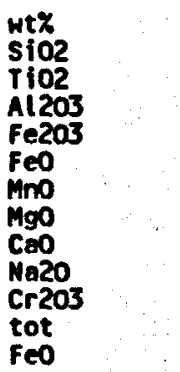 & $\begin{array}{r}53.55 \\
0.46 \\
1.35 \\
0.51 \\
18.05 \\
0.44 \\
24.46 \\
1.98 \\
0.01 \\
\text { na } \\
100.81 \\
18.51\end{array}$ & $\begin{array}{r}54.12 \\
0.24 \\
0.84 \\
0.49 \\
17.56 \\
0.41 \\
25.09 \\
1.85 \\
0.02 \\
100.69 \\
18.62 \\
18.00\end{array}$ & $\begin{array}{r}53.57 \\
0.52 \\
1.04 \\
0.38 \\
17.94 \\
0.41 \\
24.54 \\
1.96 \\
0.02 \\
100.39 \\
18.29\end{array}$ & $\begin{array}{r}52.28 \\
0.61 \\
1.20 \\
0.59 \\
21.43 \\
0.45 \\
21.70 \\
2.02 \\
0.04 \\
100.32 \\
21.96\end{array}$ & $\begin{array}{r}53.47 \\
0.50 \\
1.26 \\
0.16 \\
18.25 \\
0.38 \\
24.14 \\
2.08 \\
0.03 \\
n 10 \\
100.27 \\
18.39\end{array}$ & $\begin{array}{r}53.11 \\
0.48 \\
1.68 \\
0.48 \\
18.26 \\
0.39 \\
24.02 \\
1.96 \\
0.04 \\
100.42 \\
18.42\end{array}$ & $\begin{array}{r}53.97 \\
0.36 \\
0.77 \\
0.00 \\
18.00 \\
0.39 \\
24.62 \\
1.84 \\
0.02 \\
99.98 \\
98.97 \\
18.00\end{array}$ & $\begin{array}{r}49.80 \\
0.21 \\
2.68 \\
0.88 \\
27.26 \\
0.64 \\
17.83 \\
0.28 \\
0.02 \\
n a \\
99.60 \\
28.05\end{array}$ & $\begin{array}{r}53.61 \\
0.32 \\
0.74 \\
0.57 \\
17.82 \\
0.38 \\
24.62 \\
1.95 \\
0.02 \\
\text { na } \\
100.03 \\
18.33\end{array}$ & $\begin{array}{r}53.90 \\
0.23 \\
1.12 \\
0.37 \\
16.69 \\
0.38 \\
25.51 \\
1.64 \\
0.04 \\
\text { na } \\
99.88 \\
17.02\end{array}$ & $\begin{array}{r}53.78 \\
0.48 \\
1.42 \\
0.08 \\
17.45 \\
0.43 \\
24.85 \\
1.89 \\
0.04 \\
100 \\
100.42 \\
17.52\end{array}$ & $\begin{array}{r}53.78 \\
0.31 \\
1.65 \\
0.41 \\
16.61 \\
0.36 \\
25.42 \\
1.87 \\
0.02 \\
100.43 \\
10.43 \\
16.98\end{array}$ & $\begin{array}{r}53.28 \\
0.30 \\
1.98 \\
0.69 \\
15.84 \\
0.29 \\
25.75 \\
1.63 \\
0.04 \\
99.80 \\
99.80 \\
16.46\end{array}$ & $\begin{array}{r}52.37 \\
0.42 \\
1.34 \\
0.68 \\
21.04 \\
0.38 \\
22.43 \\
0.95 \\
0.02 \\
100.23 \\
100.23 \\
22.25\end{array}$ & $\begin{array}{r}52.79 \\
0.34 \\
0.55 \\
0.23 \\
22.25 \\
0.41 \\
21.62 \\
1.91 \\
0.02 \\
100.12 \\
22.46\end{array}$ & $\begin{array}{r}53.47 \\
0.25 \\
1.41 \\
0.42 \\
18.38 \\
0.35 \\
24.59 \\
1.36 \\
0.01 \\
100.24 \\
18.76\end{array}$ \\
\hline 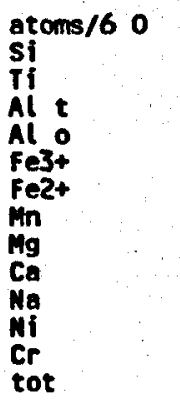 & $\begin{array}{l}1.9518 \\
0.0126 \\
0.0482 \\
0.0098 \\
0.0139 \\
0.05504 \\
0.0136 \\
1.3287 \\
0.0773 \\
0.0007 \\
0.0000 \\
0.0000 \\
4.0069\end{array}$ & $\begin{array}{l}1.9694 \\
0.0066 \\
0.0306 \\
0.0055 \\
0.0134 \\
0.5344 \\
0.0126 \\
1.3607 \\
0.0721 \\
0.0014 \\
0.0000 \\
0.0000 \\
4.0067\end{array}$ & $\begin{array}{l}1.9587 \\
0.0143 \\
0.0413 \\
0.0035 \\
0.0106 \\
0.5487 \\
0.0127 \\
1.3372 \\
0.0768 \\
0.0014 \\
0.0000 \\
0.0000 \\
4.0053\end{array}$ & $\begin{array}{l}1.9497 \\
0.0171 \\
0.0503 \\
0.0024 \\
0.0166 \\
0.0683 \\
0.0142 \\
1.2060 \\
0.0807 \\
0.0029 \\
0.0000 \\
0.0000 \\
4.0083\end{array}$ & $\begin{array}{l}1.9579 \\
0.0138 \\
0.0421 \\
0.0123 \\
0.0043 \\
0.5588 \\
0.0118 \\
1.3174 \\
0.0816 \\
0.0021 \\
0.0000 \\
0.0000 \\
4.0022\end{array}$ & $\begin{array}{l}1.9453 \\
0.0132 \\
0.0547 \\
0.0178 \\
0.0133 \\
0.5593 \\
0.0121 \\
1.3112 \\
0.0769 \\
0.0028 \\
0.0000 \\
0.0000 \\
4.0066\end{array}$ & $\begin{array}{l}1.9756 \\
0.0099 \\
0.0244 \\
0.0088 \\
0.0000 \\
0.5511 \\
0.0121 \\
1.3431 \\
0.0722 \\
0.0014 \\
0.0000 \\
0.0000 \\
3.9986\end{array}$ & $\begin{array}{l}1.9209 \\
0.0061 \\
0.0791 \\
0.0428 \\
0.0255 \\
0.8793 \\
0.0209 \\
1.0250 \\
0.0116 \\
0.0015 \\
0.0000 \\
0.0000 \\
4.0128\end{array}$ & $\begin{array}{l}1.9678 \\
0.0088 \\
0.0320 \\
0.0000 \\
0.0158 \\
0.5469 \\
0.0118 \\
1.3468 \\
0.0767 \\
0.0014 \\
0.0000 \\
0.0000 \\
4.0081\end{array}$ & $\begin{array}{l}1.5 \\
0.8 \\
0.0 \\
0.0 \\
0.0 \\
0.5 \\
0.0 \\
1.8 \\
0.0 \\
0.0 \\
0.0 \\
0.0 \\
4 .\end{array}$ & $\begin{array}{l}1.9567 \\
0.0131 \\
0.0433 \\
0.0176 \\
0.0022 \\
0.5309 \\
0.0133 \\
1.3475 \\
0.0737 \\
0.0028 \\
0.0000 \\
0.0000 \\
4.0011\end{array}$ & $\begin{array}{l}1.9514 \\
0.0085 \\
0.0486 \\
0.0220 \\
0.0111 \\
0.5042 \\
0.0111 \\
1.3746 \\
0.0727 \\
0.0014 \\
0.0000 \\
0.0000 \\
4.0055\end{array}$ & $\begin{array}{l}0 . \\
0.0 \\
0.0 \\
0.0 \\
1.0 \\
0 . \\
0 . \\
0 . \\
0 .\end{array}$ & $\begin{array}{l}00 \\
18 \\
00 \\
80 \\
91 \\
38 \\
20 \\
47 \\
79 \\
14 \\
00\end{array}$ & & $\begin{array}{l}73 \\
69 \\
27 \\
81 \\
15 \\
28 \\
09 \\
15 \\
33 \\
07 \\
00 \\
00 \\
157\end{array}$ \\
\hline 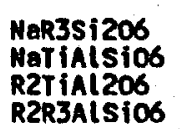 & $\begin{array}{l}0.0007 \\
0.0000 \\
0.0126 \\
0.0230\end{array}$ & $\begin{array}{l}0.0014 \\
0.0000 \\
0.0066 \\
0.0175\end{array}$ & $\begin{array}{l}0.0014 \\
0.0000 \\
0.0143 \\
0.0127\end{array}$ & $\begin{array}{l}0.0029 \\
0.0000 \\
0.0171 \\
0.0161\end{array}$ & $\begin{array}{l}0.0021 \\
0.0000 \\
0.0138 \\
0.0145\end{array}$ & $\begin{array}{l}0.0028 \\
0.0000 \\
0.0132 \\
0.0283\end{array}$ & $\begin{array}{l}0.0014 \\
0.0000 \\
0.0099 \\
0.0046\end{array}$ & $\begin{array}{l}0.0015 \\
0.0000 \\
0.0061 \\
0.0669\end{array}$ & $\begin{array}{l}0.0 \\
0.0 \\
0.0 \\
0.0\end{array}$ & $\begin{array}{l}0.5 \\
0.4 \\
0.4 \\
0.8\end{array}$ & & $\begin{array}{l}14 \\
00 \\
85 \\
17\end{array}$ & & & & \\
\hline No & $\begin{array}{l}0.0403 \\
0.6786 \\
0.2811 \\
70.7\end{array}$ & $\begin{array}{l}0.0371 \\
0.6914 \\
0.2715 \\
71.8\end{array}$ & $\begin{array}{l}0.0397 \\
0.6809 \\
0.2794 \\
70.9\end{array}$ & $\begin{array}{l}0.0420 \\
0.6164 \\
0.3416 \\
64.3\end{array}$ & $\begin{array}{l}0.0423 \\
0.6724 \\
0.2853 \\
70.2\end{array}$ & $\begin{array}{l}0.0404 \\
0.6727 \\
0.2869 \\
70.1\end{array}$ & $\begin{array}{l}0.0370 \\
0.6829 \\
0.2802 \\
70.9\end{array}$ & $\begin{array}{l}0.0063 \\
0.05349 \\
0.4589 \\
53.8\end{array}$ & $\begin{array}{l}0.0394 \\
0.6832 \\
0.2774 \\
71.1\end{array}$ & $\begin{array}{l}0.0332 \\
0.07072 \\
0.2596 \\
73.1\end{array}$ & $\begin{array}{l}0.0383 \\
0.6899 \\
0.2718 \\
71.7\end{array}$ & $\begin{array}{l}0.0380 \\
0.7038 \\
0.2582 \\
73.2\end{array}$ & $\begin{array}{l}0.0336 \\
0.7165 \\
0.2479 \\
74.3\end{array}$ & & & \\
\hline
\end{tabular}




\begin{tabular}{|c|c|c|c|c|c|c|c|c|c|c|c|c|c|c|c|c|}
\hline $\begin{array}{l}\text { Strat\# } \\
\text { Field\# } \\
\text { Grain }\end{array}$ & $\begin{array}{r}\mathrm{cP}-07 \\
85 \mathrm{cns} 60 \\
02 \mathrm{r} \\
137\end{array}$ & $\begin{array}{r}c P-07 \\
85 \mathrm{cns60} \\
03 p c \\
132\end{array}$ & $\begin{array}{r}\mathrm{CP}-12 \\
85 \mathrm{cns} 20 \\
06=012 \mathrm{j}\end{array}$ & $\begin{array}{r}\text { CP-12 } \\
85 \mathrm{cns} 20 \\
01 \mathrm{C} \\
261\end{array}$ & $\begin{array}{r}\text { CP- } 12 \\
85 \mathrm{cns} 20 \\
01 r \\
262\end{array}$ & $\begin{array}{r}c P-12 \\
85 \mathrm{cns} 20 \\
02 c \\
263\end{array}$ & $\begin{array}{r}c P-12 \\
85 \mathrm{cns} 20 \\
02 \mathrm{r} \\
264\end{array}$ & $\begin{array}{r}c P-12 \\
85 \mathrm{cns} 20 \\
03 \mathrm{c} \\
265\end{array}$ & $\begin{array}{r}c P-12 \\
85 c n s 20 \\
03 r \\
266\end{array}$ & $\begin{array}{r}\text { CP.12 } \\
85 \mathrm{cns} 20 \\
04 c \\
267\end{array}$ & $\begin{array}{r}\text { CP-12 } \\
85 \text { cns20 } \\
04 r \\
268\end{array}$ & $\begin{array}{r}\mathrm{CP}-12 \\
85 \mathrm{cns} 20 \\
05 \mathrm{C} \\
269\end{array}$ & $\begin{array}{r}c P-12 \\
85 \mathrm{cns} 20 \\
05 r \\
270\end{array}$ & $\begin{array}{r}\text { PUA- } 17 \\
85 \mathrm{cns} 17 \\
01 \mathrm{c} \\
240\end{array}$ & $\begin{array}{r}\text { PUM-17 } \\
85 \mathrm{cns} 17 \\
01 r \\
241\end{array}$ & $\begin{array}{r}\text { PUM-17 } \\
85 \mathrm{cns} 17 \\
02 \mathrm{c} \\
242\end{array}$ \\
\hline $\begin{array}{l}\text { wt\% } \\
\text { sio2 } \\
\text { Ti02 } \\
\text { Al203 } \\
\text { Fezo3 } \\
\text { Feo } \\
\text { MnO } \\
\text { MgO } \\
\text { CaO } \\
\text { Na20 } \\
\text { Cr203 } \\
\text { tot } \\
\text { Feo }\end{array}$ & $\begin{array}{r}52.35 \\
0.48 \\
0.93 \\
0.65 \\
20.75 \\
0.41 \\
22.19 \\
1.82 \\
0.06 \\
n \text { ng } \\
99.63 \\
21.33\end{array}$ & $\begin{array}{r}54.43 \\
0.21 \\
1.61 \\
0.46 \\
13.76 \\
0.32 \\
27.68 \\
1.54 \\
0.02 \\
n a \\
100.04 \\
14.18\end{array}$ & $\begin{array}{r}53.18 \\
0.24 \\
1.57 \\
0.67 \\
20.01 \\
0.64 \\
23.45 \\
1.22 \\
0.02 \\
0.04 \\
101.04 \\
20.61\end{array}$ & $\begin{array}{r}53.99 \\
0.25 \\
1.88 \\
0.83 \\
14.53 \\
0.38 \\
26.88 \\
1.68 \\
0.04 \\
0.04 \\
100.50 \\
15.28\end{array}$ & $\begin{array}{r}54.75 \\
0.25 \\
0.70 \\
0.35 \\
16.87 \\
0.43 \\
26.01 \\
1.64 \\
0.02 \\
0.00 \\
101.01 \\
17.18\end{array}$ & $\begin{array}{r}51.50 \\
0.29 \\
2.80 \\
0.52 \\
23.31 \\
0.49 \\
21.09 \\
0.50 \\
0.01 \\
0.10 \\
100.60 \\
23.77\end{array}$ & $\begin{array}{r}55.02 \\
0.18 \\
0.86 \\
0.46 \\
15.06 \\
0.38 \\
26.86 \\
1.68 \\
0.02 \\
0.06 \\
101.19 \\
16.08\end{array}$ & $\begin{array}{r}54.30 \\
0.16 \\
0.93 \\
0.55 \\
15.92 \\
0.42 \\
26.36 \\
1.49 \\
0.02 \\
0.04 \\
100.19 \\
16.41\end{array}$ & $\begin{array}{r}54.39 \\
0.28 \\
0.82 \\
0.26 \\
16.90 \\
0.46 \\
25.81 \\
1.56 \\
0.01 \\
0.05 \\
100.54 \\
17.13\end{array}$ & $\begin{array}{r}54.47 \\
0.23 \\
1.00 \\
0.95 \\
16.96 \\
0.43 \\
26.03 \\
1.51 \\
0.01 \\
0.02 \\
101.62 \\
17.82\end{array}$ & $\begin{array}{r}55.03 \\
0.20 \\
0.95 \\
0.52 \\
15.60 \\
0.41 \\
26.98 \\
1.62 \\
0.01 \\
0.02 \\
101.33 \\
16.06\end{array}$ & $\begin{array}{r}53.02 \\
0.25 \\
1.10 \\
0.09 \\
22.91 \\
0.44 \\
21.72 \\
1.21 \\
0.01 \\
0.05 \\
100.80 \\
22.99\end{array}$ & $\begin{array}{r}54.14 \\
0.10 \\
0.82 \\
0.95 \\
16.93 \\
0.48 \\
25.68 \\
1.55 \\
0.02 \\
0.00 \\
100.67 \\
17.78\end{array}$ & $\begin{array}{r}54.81 \\
0.23 \\
0.93 \\
0.35 \\
16.06 \\
0.54 \\
26.50 \\
1.47 \\
0.04 \\
0.00 \\
100.94 \\
16.38\end{array}$ & $\begin{array}{r}54.88 \\
0.16 \\
1.10 \\
0.01 \\
16.16 \\
0.59 \\
26.45 \\
1.39 \\
0.02 \\
0.04 \\
100.80 \\
16.17\end{array}$ & $\begin{array}{r}53.56 \\
0.18 \\
1.94 \\
1.22 \\
16.41 \\
0.50 \\
26.00 \\
1.03 \\
0.04 \\
0.07 \\
100.94\end{array}$ \\
\hline $\begin{array}{l}\text { atoms } 160 \\
\text { si } \\
\text { Ti } \\
\text { Al t } \\
\text { Al o } \\
\text { Fe3+ } \\
\text { Fe2+ } \\
\text { min } \\
\text { Mg } \\
\text { Ca } \\
\text { Na } \\
\mathrm{Ni} \\
\mathrm{Cr}\end{array}$ & $\begin{array}{l}1.9591 \\
0.0135 \\
0.0409 \\
0.0001 \\
0.0182 \\
0.6494 \\
0.0130 \\
1.2376 \\
0.0730 \\
0.0044 \\
0.0000 \\
0.0000 \\
4.0091\end{array}$ & $\begin{array}{l}1.9547 \\
0.0057 \\
0.0453 \\
0.0229 \\
0.0125 \\
0.4134 \\
0.0097 \\
1.4815 \\
0.0593 \\
0.0014 \\
0.0000 \\
0.0000\end{array}$ & $\begin{array}{l}1.9504 \\
0.0066 \\
0.0496 \\
0.0183 \\
0.0184 \\
0.6138 \\
0.0199 \\
1.2817 \\
0.0479 \\
0.0014 \\
0.0000 \\
0.0012 \\
4.0092\end{array}$ & $\begin{array}{l}1.9429 \\
0.0068 \\
0.0571 \\
0.0227 \\
0.0225 \\
0.4374 \\
0.0116 \\
1.4416 \\
0.0648 \\
0.0028 \\
0.0000 \\
0.0011 \\
4.0113\end{array}$ & $\begin{array}{l}0.0068 \\
0.0257 \\
0.0041 \\
0.0094 \\
0.5087 \\
0.0131 \\
1.3978 \\
0.0634 \\
0.0014 \\
0.0000 \\
0.0000 \\
4.0047\end{array}$ & $\begin{array}{l}0.0081 \\
0.0781 \\
0.0451 \\
0.0145 \\
0.7274 \\
0.0155 \\
1.1730 \\
0.0200 \\
0.0007 \\
0.0000 \\
0.0030 \\
4.0072\end{array}$ & $\begin{array}{l}0.0048 \\
0.0294 \\
0.0069 \\
0.0125 \\
0.4692 \\
0.0115 \\
1.4337 \\
0.0645 \\
0.0014 \\
0.0000 \\
0.0017 \\
4.0062\end{array}$ & $\begin{array}{l}0.0 \\
0.0 \\
0.0 \\
0.0 \\
0.4 \\
0.0 \\
1.4 \\
0.0 \\
0.0 \\
0.0 \\
0.0 \\
4.0\end{array}$ & $\begin{array}{l}0.00 \\
0.02 \\
0.00 \\
0.00 \\
0.51 \\
0.01 \\
1.39 \\
0.06 \\
0.00 \\
0.00 \\
0.00 \\
4.00\end{array}$ & $\begin{array}{l}0.00 \\
0.04 \\
0.00 \\
0.02 \\
0.5 \\
0.01 \\
1.35 \\
0.05 \\
0.00 \\
0.00 \\
0.00 \\
4.01\end{array}$ & $\begin{array}{l}0.0 \\
0.0 \\
0.0 \\
0.0 \\
0.0 \\
0.0 \\
1.0 \\
0.0 \\
0.0 \\
0.0 \\
0.0\end{array}$ & $\begin{array}{l}0 . \\
0 . \\
0 . \\
0 . \\
0 . \\
0 . \\
1 . \\
0 . \\
0 . \\
0 . \\
0 .\end{array}$ & $\begin{array}{l}0.1 \\
0.1 \\
0.1 \\
0.1 \\
0.1 \\
0.1 \\
1 . \\
0.1 \\
0 . \\
0 . \\
0 .\end{array}$ & & & $\begin{array}{l}0 . \\
0 . \\
0 . \\
0 . \\
1 . \\
0 . \\
0 . \\
0 .\end{array}$ \\
\hline $\begin{array}{l}\text { NaR3sizo6 } \\
\text { NaTiAtsio6 } \\
\text { R2TiAtzo6 } \\
\text { R2R3AIsio6 }\end{array}$ & $\begin{array}{l}0.0044 \\
0.0000 \\
0.0135 \\
0.0139\end{array}$ & $\begin{array}{l}0.0000 \\
0.0057 \\
0.0340\end{array}$ & $\begin{array}{l}0.0000 \\
0.0066 \\
0.0364\end{array}$ & $\begin{array}{l}0.0000 \\
0.0068 \\
0.0435\end{array}$ & $\begin{array}{l}0.00 \\
0.00 \\
0.01\end{array}$ & $\begin{array}{l}0.0007 \\
0.0000 \\
0.0081 \\
0.0618\end{array}$ & $\begin{array}{l}0.0 \\
0.0 \\
0.0\end{array}$ & $\begin{array}{l}0.0 \\
0.0 \\
0.0\end{array}$ & $\begin{array}{l}0.0 \\
0.0 \\
0.0\end{array}$ & $\begin{array}{l}0.0 \\
0.0 \\
0.0 \\
0.0\end{array}$ & $\begin{array}{l}0.0 \\
0.0 \\
0.0 \\
0.0\end{array}$ & $\begin{array}{l}0.1 \\
0.1 \\
0.1\end{array}$ & 0. & & & \\
\hline $\begin{array}{l}\text { Ho } \\
\text { En } \\
\text { Fs } \\
\text { Mg\# }\end{array}$ & $\begin{array}{r}0.0378 \\
0.6311 \\
0.3312 \\
65.6\end{array}$ & $\begin{array}{r}0.0310 \\
0.7576 \\
0.2114 \\
78.2\end{array}$ & $\begin{array}{r}0.0252 \\
0.6591 \\
0.3156 \\
67.6\end{array}$ & $\begin{array}{r}0.7410 \\
0.2248 \\
76.7\end{array}$ & $\begin{array}{r}0.0325 \\
0.7094 \\
0.2581 \\
73.3\end{array}$ & $\begin{array}{r}0.6106 \\
0.3786 \\
61.7\end{array}$ & $\begin{array}{l}0.7284 \\
0.2384 \\
75.3\end{array}$ & $\begin{array}{r}0.7246 \\
0.2455 \\
74.7\end{array}$ & $\begin{array}{r}0.7085 \\
0.2603 \\
73.1\end{array}$ & $\begin{array}{l}0.7101 \\
0.2597 \\
73.2\end{array}$ & $\begin{array}{l}0.0320 \\
0.7309 \\
0.2371 \\
75.5\end{array}$ & $\begin{array}{l}0.0 \\
0.6 \\
0.36 \\
6\end{array}$ & $\begin{array}{r}0.0 \\
0.7 \\
0.2 \\
7\end{array}$ & $\begin{array}{l}0.0 \\
0.7 \\
0.2 \\
7\end{array}$ & $\begin{array}{l}7 \\
0 \\
3 \\
5\end{array}$ & 0.2 \\
\hline
\end{tabular}




\begin{tabular}{|c|c|c|c|c|c|c|c|c|c|}
\hline $\begin{array}{l}\text { Strat\# } \\
\text { Field\# } \\
\text { Grain }\end{array}$ & $\begin{array}{r}\text { PuM- } 17 \\
85 \mathrm{crs} 17 \\
02 r \\
243\end{array}$ & $\begin{array}{r}\text { Pum-17 } \\
85 \mathrm{cns} 17 \\
03 \mathrm{c} \\
244\end{array}$ & $\begin{array}{r}\text { PUM-17 } \\
85 \mathrm{cns} 17 \\
03 \mathrm{r} \\
245\end{array}$ & $\begin{array}{r}\text { PUM-17 } \\
85 \mathrm{cns} 17 \\
04 j \\
239\end{array}$ & $\begin{array}{r}\text { PUM-17 } \\
85 \mathrm{cns} 17 \\
04 \mathrm{pc} \\
238\end{array}$ & $\min$ & $\max$ & mean & sdev \\
\hline $\begin{array}{l}\text { Htz } \\
\text { sio2 } \\
\text { TiOO } \\
\text { Alzo3 } \\
\text { Fe203 } \\
\text { FeO } \\
\text { MnO } \\
\text { MgO } \\
\text { CaO } \\
\text { Na2O } \\
\text { Cr203 }\end{array}$ & $\begin{array}{r}54.48 \\
0.16 \\
0.87 \\
0.80 \\
16.02 \\
0.50 \\
26.47 \\
1.45 \\
0.02 \\
0.00 \\
100.77 \\
16.74\end{array}$ & $\begin{array}{r}54.72 \\
0.14 \\
0.96 \\
0.36 \\
16.44 \\
0.49 \\
26.18 \\
1.48 \\
0.05 \\
0.02 \\
100.85 \\
16.77\end{array}$ & $\begin{array}{r}54.38 \\
0.27 \\
1.13 \\
0.06 \\
18.44 \\
0.63 \\
24.99 \\
1.28 \\
0.01 \\
0.00 \\
101.19 \\
18.49\end{array}$ & $\begin{array}{r}53.92 \\
0.05 \\
0.96 \\
1.31 \\
14.57 \\
0.45 \\
26.92 \\
1.54 \\
0.03 \\
0.00 \\
99.75 \\
15.75\end{array}$ & $\begin{array}{r}49.88 \\
0.21 \\
3.07 \\
1.63 \\
26.78 \\
0.77 \\
18.34 \\
0.18 \\
0.02 \\
0.04 \\
100.91 \\
28.24\end{array}$ & $\begin{array}{r}49.80 \\
0.05 \\
0.41 \\
0.00 \\
9.73 \\
0.24 \\
16.05 \\
0.18 \\
0.00 \\
0.00 \\
98.37 \\
9.73\end{array}$ & $\begin{array}{r}55.03 \\
0.63 \\
4.43 \\
1.89 \\
27.26 \\
0.91 \\
30.20 \\
2.59 \\
0.92 \\
0.10 \\
102.03 \\
28.24\end{array}$ & $\begin{array}{r}53.48 \\
0.24 \\
1.23 \\
0.62 \\
18.33 \\
0.52 \\
24.45 \\
1.41 \\
0.03 \\
0.01 \\
100.32 \\
18.89\end{array}$ & $\begin{array}{l}0.89 \\
0.11 \\
0.65 \\
0.40 \\
3.28 \\
0.18 \\
2.27 \\
0.36 \\
0.08 \\
0.02 \\
0.84 \\
3.25\end{array}$ \\
\hline $\begin{array}{l}\text { atcoms } / 60 \\
\text { Si } \\
T i \\
\text { Ai t } \\
\text { Al o } \\
\text { Fe3+ } \\
\text { Fe2+ } \\
\text { Mn } \\
\text { Mg } \\
\mathrm{Ca} \\
\mathrm{Ma} \\
\mathrm{Mi} \\
\mathrm{Cr} \\
\text { tot }\end{array}$ & $\begin{array}{l}1.9670 \\
0.0043 \\
0.0330 \\
0.0040 \\
0.0217 \\
0.4837 \\
0.0153 \\
1.4243 \\
0.0561 \\
0.0014 \\
0.0000 \\
0.0000 \\
4.0109\end{array}$ & $\begin{array}{l}1.9723 \\
0.0038 \\
0.0277 \\
0.0131 \\
0.0099 \\
0.4956 \\
0.0150 \\
1.4063 \\
0.0572 \\
0.0035 \\
0.0000 \\
0.0006\end{array}$ & $\begin{array}{l}1.9681 \\
0.0073 \\
0.0319 \\
0.0163 \\
0.0016 \\
0.5580 \\
0.0193 \\
1.3479 \\
0.0496 \\
0.0007 \\
0.0000 \\
0.0000\end{array}$ & $\begin{array}{l}1.9611 \\
0.0014 \\
0.0389 \\
0.0023 \\
0.0359 \\
0.4432 \\
0.0139 \\
1.4592 \\
0.0600 \\
0.0021 \\
0.0000 \\
0.0000\end{array}$ & $\begin{array}{l}0.0 \\
0.0 \\
0.0 \\
0.0 \\
0.8 \\
0.0 \\
1.0 \\
0.0 \\
0.0 \\
0.0 \\
0.0 \\
4.0\end{array}$ & $\begin{array}{c}1 . \\
0 . \\
0 . \\
0 . \\
0 . \\
0 . \\
0 . \\
0 . \\
0 . \\
0 . \\
0 . \\
0 . \\
3 .\end{array}$ & $\begin{array}{l}0 . \\
0 . \\
1 \\
0 . \\
0 . \\
0 .\end{array}$ & & \\
\hline $\begin{array}{l}\text { NaR3Siz } 206 \\
\text { NaTiALSIOS } \\
\text { R2TiAt206 }\end{array}$ & $\begin{array}{l}0.0 \\
0.01 \\
0.0 \\
0.0\end{array}$ & .0 & 0.0 & $\begin{array}{l}0.0 \\
0.0 \\
0.0\end{array}$ & $\begin{array}{l}0 . \\
0 . \\
0 . \\
0 .\end{array}$ & $\begin{array}{r}0 . \\
-0 . \\
0 . \\
0 .\end{array}$ & $\begin{array}{l}1 \\
0 \\
1 \\
1\end{array}$ & & \\
\hline $\begin{array}{l}\text { Wo } \\
\text { En } \\
\text { Fs }\end{array}$ & $\begin{array}{l}0.0 \\
0.7 \\
0.2\end{array}$ & $\begin{array}{l}0.02 \\
0.71 \\
0.25\end{array}$ & $\begin{array}{l}0.0 \\
0.6 \\
0.2\end{array}$ & $\begin{array}{l}0.7 \\
0.2 \\
7\end{array}$ & $\begin{array}{l}0.0 \\
0.5 \\
0.4 \\
5\end{array}$ & $\begin{array}{l}0.09 \\
0.5 \\
0.1 \\
5\end{array}$ & $\begin{array}{r}0.8 \\
0.4 \\
8\end{array}$ & $\begin{array}{l}0.1 \\
0.8 \\
0.8\end{array}$ & $\begin{array}{r}0.0074 \\
0.0529 \\
0.0557 \\
5.6\end{array}$ \\
\hline
\end{tabular}




\section{APPENDIX VII - Hornblende compositions}

Plagioclase compositons were determined on the JEOL JXA-733 microprobe at Southern Methodist University using standard analytical stratagies and instrumental settings. 
Spurr Volcanic Complex hornblende analyses

\begin{tabular}{|c|c|c|c|c|c|c|c|c|c|c|c|c|c|c|c|c|c|c|}
\hline \# & $\begin{array}{r}\text { SP-04 } \\
\text { sp-rs4 } \\
\text { hb1c } \\
33\end{array}$ & $\begin{array}{r}\text { sp-04 } \\
\text { sp-rs4 } \\
\text { hbir } \\
34\end{array}$ & $\begin{array}{r}s p-04 \\
s p-r 84 \\
h b 3 c \\
38\end{array}$ & $\begin{array}{r}s p-04 \\
s p-r s 4 \\
h b 3 r \\
39\end{array}$ & $\begin{array}{r}\text { PF-38 } \\
85 \mathrm{cns} 38 \\
\text { hbic }\end{array}$ & $\begin{array}{r}\text { PF }-38 \\
85 \text { cns38 } \\
\text { hb2c } \\
2\end{array}$ & $\begin{array}{r}\text { PF-38 } \\
85 \text { cns38 }\end{array}$ & $\begin{array}{r}P-B 01 \\
\text { hbns33 } \\
27\end{array}$ & $\begin{array}{r}\text { PCP-B01 } \\
85 \mathrm{cns} 33 \\
\mathrm{hb} 1 \mathrm{r} \\
28\end{array}$ & $\begin{array}{r}P C P-B 01 \\
85 \mathrm{cns33} \\
\mathrm{hb2c} \\
29\end{array}$ & $\begin{array}{r}\text { PCP-B01 } \\
85 \mathrm{cns33} \\
\mathrm{hb2r} \\
30\end{array}$ & $\begin{array}{r}\text { PCP-B01 } \\
85 c n s 33 \\
\text { hb3c } \\
31\end{array}$ & $\begin{array}{c}\text { PCP-B01 } \\
85 \text { cns33 } \\
\text { hb3r. }\end{array}$ & $\begin{array}{r}c P-12 \\
85 c n s 20 \\
h b 1 c \\
23\end{array}$ & $\begin{array}{r}c p-12 \\
5 c n s 20 \\
h b 1 r \\
24\end{array}$ & $\begin{array}{r}c P-12 \\
85 \mathrm{cns} 20 \\
\mathrm{hb2c} \\
25\end{array}$ & $\begin{array}{r}\text { CP-12 } \\
5 \text { cns } 20 \\
\text { hb2r } \\
26\end{array}$ & \\
\hline $\begin{array}{l}102 \\
1203 \\
=203 \\
=0 \\
00 \\
90 \\
00 \\
00 \\
920 \\
7203 \\
20 \\
1 \\
\text { otal } \\
00 \text { meas. }\end{array}$ & $\begin{array}{r}42.75 \\
1.93 \\
13.40 \\
9.63 \\
2.47 \\
0.12 \\
14.56 \\
11.13 \\
200 \\
2.35 \\
0.03 \\
0.32 \\
0.15 \\
0.00 \\
98.83 \\
11.13\end{array}$ & $\begin{array}{r}43.00 \\
2.41 \\
12.83 \\
9.42 \\
1.38 \\
0.17 \\
15.11 \\
11.11 \\
\text { na } \\
2.47 \\
0.36 \\
0.38 \\
0.00 \\
0.00 \\
98.64 \\
9.86\end{array}$ & $\begin{array}{r}43.00 \\
1.61 \\
13.00 \\
10.33 \\
0.87 \\
0.11 \\
15.42 \\
11.11 \\
\text { na } \\
2.40 \\
0.05 \\
0.27 \\
0.15 \\
0.02 \\
98.33 \\
10.16\end{array}$ & $\begin{array}{r}1.70 \\
12.66 \\
8.83 \\
1.84 \\
0.12 \\
15.47 \\
11.44 \\
0.46 \\
2.28 \\
0.04 \\
0.34 \\
0.09 \\
0.00 \\
97.67 \\
9.79\end{array}$ & $\begin{array}{r}2.16 \\
14.86 \\
11.38 \\
3.47 \\
0.20 \\
12.23 \\
10.36 \\
0.07 \\
2.36 \\
\text { na } \\
0.26 \\
0.09 \\
0.03 \\
98.62 \\
13.71\end{array}$ & $\begin{array}{r}41.79 \\
2.46 \\
14.31 \\
10.44 \\
5.08 \\
0.16 \\
12.29 \\
10.74 \\
0.10 \\
2.47 \\
\text { na } \\
0.28 \\
0.05 \\
0.00 \\
100.18 \\
14.48\end{array}$ & $\begin{array}{r}2.38 \\
14.02 \\
12.40 \\
3.57 \\
0.16 \\
12.53 \\
10.52 \\
0.07 \\
2.45 \\
\text { na } \\
0.28 \\
0.07 \\
0.02 \\
99.68 \\
14.73\end{array}$ & $\begin{array}{r}3.62 \\
12.34 \\
6.64 \\
6.55 \\
0.16 \\
13.28 \\
11.28 \\
\text { na } \\
2.45 \\
0.09 \\
0.46 \\
0.16 \\
0.01 \\
98.48 \\
12.52\end{array}$ & $\begin{array}{r}3.72 \\
12.23 \\
8.43 \\
5.55 \\
0.12 \\
13.38 \\
11.30 \\
n 0 \\
2.46 \\
0.07 \\
0.39 \\
0.09 \\
0.02 \\
98.05 \\
13.13\end{array}$ & $\begin{array}{r}3.40 \\
12.79 \\
9.21 \\
3.35 \\
0.15 \\
13.96 \\
11.34 \\
\text { na } \\
2.45 \\
0.13 \\
0.46 \\
0.02 \\
0.02 \\
96.21 \\
11.64\end{array}$ & $\begin{array}{r}2.59 \\
12.90 \\
9.97 \\
1.82 \\
0.18 \\
14.80 \\
11.16 \\
n 9 \\
2.44 \\
0.08 \\
0.38 \\
0.17 \\
0.00 \\
97.61 \\
10.80\end{array}$ & $\begin{array}{r}41 . \\
2 . \\
8 . \\
3 . \\
0 . \\
14 . \\
11 . \\
2 . \\
0 . \\
0 . \\
0 . \\
0 . \\
98 . \\
10 .\end{array}$ & $\begin{array}{r}3 \\
12 \\
9 \\
4 . \\
0 . \\
13 . \\
11 . \\
2 . \\
0 . \\
0 . \\
0 .\end{array}$ & $\begin{array}{r}42 . \\
3 . \\
11 . \\
5 . \\
7 . \\
0 . \\
13 . \\
11 . \\
0 . \\
2 . \\
0 . \\
0 . \\
0 . \\
08 .\end{array}$ & $\begin{array}{r}41.82 \\
3.34 \\
11.72 \\
7.09 \\
6.14 \\
0.17 \\
13.57 \\
11.18 \\
0.03 \\
2.50 \\
0.03 \\
0.31 \\
0.28 \\
0.06 \\
98.24\end{array}$ & $\begin{array}{r}3 \\
12 \\
6 \\
6 \\
0 \\
13 \\
11 \\
0 \\
2 \\
0 \\
0 \\
0 \\
0\end{array}$ & $\begin{array}{r}3 \\
11 \\
6 \\
7 \\
0 \\
13 \\
11 \\
0 \\
2 \\
0 \\
0 \\
0 \\
0 \\
99\end{array}$ & $\begin{array}{r}2 . \\
13 \\
8 \\
3 \\
0 . \\
14 . \\
11 . \\
0 . \\
2 \\
0 \\
0 \\
0 \\
0\end{array}$ \\
\hline $\begin{array}{l}\text { ri } \\
\text { Al } \\
\text { Al } \\
\text { Fe3+ } \\
\text { Fe2t } \\
\text { Mn } \\
\text { Mg } \\
\text { Ca } \\
\text { Ba } \\
\text { Ma } \\
\text { Mi } \\
\text { Cr } \\
K \\
\text { F } \\
\text { Cl }\end{array}$ & 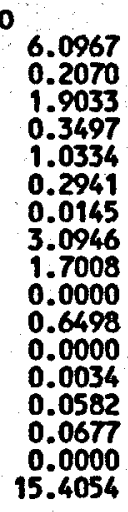 & $\begin{array}{l}6.1149 \\
0.2577 \\
1.8851 \\
0.2658 \\
1.0085 \\
0.1642 \\
0.0205 \\
3.2023 \\
1.6929 \\
0.0000 \\
0.6811 \\
0.0000 \\
0.0405 \\
0.0689 \\
0.0000\end{array}$ & $\begin{array}{l}6.1 \\
0.1 \\
1.8 \\
0.3 \\
1.1 \\
0.1 \\
0.0 \\
3.2 \\
1.6 \\
0.0 \\
0.6 \\
0.0 \\
0.0 \\
0.0 \\
0.0 \\
0.0\end{array}$ & $\begin{array}{l}6.15 \\
0.18 \\
1.84 \\
0.30 \\
0.95 \\
0.22 \\
0.01 \\
3.31 \\
1.76 \\
0.00 \\
0.63 \\
0.00 \\
0.00 \\
0.06 \\
0.04 \\
0.04\end{array}$ & $\begin{array}{l}0.23 \\
2.08 \\
0.45 \\
1.23 \\
0.41 \\
0.02 \\
2.62 \\
1.60 \\
0.00 \\
0.65 \\
0.00 \\
0.00 \\
0.04 \\
0.04 \\
0.00\end{array}$ & $\begin{array}{l}5.96 \\
0.26 \\
2.03 \\
0.36 \\
1.12 \\
0.60 \\
0.01 \\
2.61 \\
1.64 \\
0.00 \\
0.66 \\
0.00 \\
0.00 \\
0.05 \\
0.02 \\
0.00\end{array}$ & $\begin{array}{r}0.2 \\
2.0 \\
0.2 \\
1.3 \\
0.4 \\
0.0 \\
2.6 \\
1.6 \\
0.0 \\
0.6 \\
0.0 \\
0.0 \\
0.0 \\
0.0 \\
0.0 \\
15.3\end{array}$ & $\begin{array}{r}0.3 \\
1.9 \\
0.1 \\
0.7 \\
0.7 \\
0.0 \\
2.8 \\
1.7 \\
0.0 \\
0.6 \\
0.0 \\
0.0 \\
0.0 \\
0.0 \\
0.0 \\
15.5\end{array}$ & $\begin{array}{l}3 \\
1 \\
1 \\
2 \\
9 \\
2 \\
6 \\
0 \\
5 \\
0 \\
1 \\
0 \\
7 \\
0 \\
9\end{array}$ & $\begin{array}{l}8 \\
5 \\
9 \\
9 \\
2 \\
6 \\
0 \\
3 \\
0 \\
3 \\
3 \\
4 \\
0 \\
8\end{array}$ & $\begin{array}{c}0 . \\
2 . \\
0 . \\
1 . \\
0.0 \\
0.0 \\
3 . \\
0 . \\
0 . \\
0 . \\
0.0 \\
0 . \\
0 . \\
0 . \\
15 .\end{array}$ & $\begin{array}{l}0 \\
2 \\
0 \\
0 \\
0 \\
0 \\
3 \\
0 \\
0 \\
0 \\
0\end{array}$ & $\begin{array}{l}9 \\
7 \\
2 \\
6 \\
1 \\
3 \\
4 \\
6 \\
0 \\
5 \\
0 \\
2 \\
8 \\
7 \\
0 \\
4 \\
4\end{array}$ & $\begin{array}{l}6 \\
2 \\
3 \\
7 \\
6 \\
2 \\
1 \\
3 \\
0 \\
7\end{array}$ & $\begin{array}{l}3 \\
7 \\
5 \\
0 \\
6 \\
0 \\
5 \\
9 \\
7 \\
0 \\
5 \\
7 \\
3 \\
3\end{array}$ & $\begin{array}{l}0 . \\
0 . \\
0 . \\
0 . \\
2 . \\
1 . \\
0 . \\
0 . \\
0 . \\
0 . \\
0 . \\
0 .\end{array}$ & $\begin{array}{l}8 \\
5 \\
6 \\
5 \\
7 \\
6 \\
1 \\
6 \\
0 \\
7 \\
6\end{array}$ & $\begin{array}{l}0 \\
0 \\
3 \\
1 \\
0 \\
0\end{array}$ \\
\hline$F$ & $\begin{array}{r}0.70 \\
1.59 \\
9\end{array}$ & 532 & 5 & 40 & & ( & & & & & & & & & & & & \\
\hline
\end{tabular}

Mineral reduction assumes:

1: Sum of cations without $\mathrm{Ca}, \mathrm{Na}$, or $K$ is 13

3: $\mathrm{Fe} 3+/ \mathrm{Fe} 2+$ determined by charge balance. 


\begin{tabular}{|c|c|c|c|c|c|c|c|c|c|c|c|c|c|}
\hline $\begin{array}{l}\text { Strat\# } \\
\text { field\# } \\
\text { Grain }\end{array}$ & $\begin{array}{r}\text { Pum-17 } \\
85 \mathrm{cns} 17 \\
\text { hb1c2 } \\
14\end{array}$ & $\begin{array}{r}\text { Pum-17 } \\
85 \text { cns } 17 \\
\text { hb1r } \\
15\end{array}$ & $\begin{array}{r}\text { Pum-17 } \\
85 \mathrm{cns} 17 \\
\text { hb2c } \\
16\end{array}$ & $\begin{array}{r}\text { PuM-17 } \\
85 \mathrm{cns} 17 \\
\text { hb2r } \\
17\end{array}$ & $\begin{array}{r}\text { PUN-17 } \\
85 \mathrm{cns} 17 \\
\text { hb3c } \\
18\end{array}$ & $\begin{array}{r}\text { Pum-17 } \\
85 \mathrm{cns} 17 \\
\text { hb4c } \\
19\end{array}$ & $\begin{array}{r}\text { PUiA- } 17 \\
85 \mathrm{cns} 17 \\
\text { hb4r } \\
20\end{array}$ & $\begin{array}{r}\text { PuM-17 } \\
85 \mathrm{cns} 17 \\
\text { hb5c } \\
21\end{array}$ & & min & $\max$ & mean & sdev \\
\hline $\begin{array}{l}\text { wtX } \\
\text { sio2 } \\
\text { Tio2 } \\
\text { Alzos } \\
\text { Fe203 } \\
\text { FeO } \\
\text { MnO } \\
\text { MgO } \\
\text { CaO } \\
\text { BaO } \\
\text { Na20 } \\
\text { Cr203 } \\
\text { K2O } \\
\text { F } \\
\text { Cl } \\
\text { total } \\
\text { feO meas. }\end{array}$ & $\begin{array}{r}42.35 \\
2.39 \\
12.96 \\
9.48 \\
2.28 \\
0.19 \\
14.89 \\
11.14 \\
0.00 \\
2.59 \\
0.07 \\
0.27 \\
0.17 \\
0.00 \\
98.78 \\
10.81\end{array}$ & $\begin{array}{r}42.28 \\
2.43 \\
13.62 \\
9.23 \\
3.03 \\
0.17 \\
14.61 \\
11.35 \\
0.02 \\
2.61 \\
0.02 \\
0.27 \\
0.11 \\
0.00 \\
99.75 \\
11.34\end{array}$ & $\begin{array}{r}43.02 \\
2.26 \\
12.59 \\
9.97 \\
2.87 \\
0.18 \\
14.63 \\
11.06 \\
0.04 \\
2.57 \\
0.04 \\
0.26 \\
0.02 \\
0.01 \\
99.52 \\
11.84\end{array}$ & $\begin{array}{r}42.36 \\
2.23 \\
13.95 \\
8.16 \\
2.24 \\
0.10 \\
15.25 \\
11.63 \\
0.06 \\
2.64 \\
0.16 \\
0.26 \\
0.00 \\
0.00 \\
99.05 \\
9.59\end{array}$ & $\begin{array}{r}42.95 \\
2.29 \\
13.23 \\
9.37 \\
1.12 \\
0.10 \\
15.87 \\
11.52 \\
0.00 \\
2.68 \\
0.20 \\
0.23 \\
0.14 \\
0.00 \\
99.70 \\
9.55\end{array}$ & $\begin{array}{r}42.92 \\
3.41 \\
11.53 \\
6.02 \\
8.56 \\
0.27 \\
12.59 \\
11.20 \\
0.10 \\
2.41 \\
0.05 \\
0.43 \\
0.09 \\
0.06 \\
99.64 \\
13.98\end{array}$ & $\begin{array}{r}42.30 \\
2.13 \\
13.50 \\
8.53 \\
2.52 \\
0.09 \\
15.30 \\
11.64 \\
0.03 \\
2.63 \\
0.05 \\
0.27 \\
0.09 \\
0.02 \\
99.10 \\
10.20\end{array}$ & $\begin{array}{r}42.34 \\
2.43 \\
13.62 \\
8.68 \\
2.37 \\
0.11 \\
15.17 \\
11.63 \\
0.06 \\
2.62 \\
0.15 \\
0.21 \\
0.03 \\
0.04 \\
99.46 \\
10.18\end{array}$ & $\begin{array}{r}42.88 \\
2.23 \\
13.33 \\
8.18 \\
2.98 \\
0.10 \\
15.01 \\
11.38 \\
0.07 \\
2.63 \\
0.05 \\
0.24 \\
0.05 \\
0.02 \\
99.15\end{array}$ & $\begin{array}{r}38.93 \\
1.61 \\
11.53 \\
5.29 \\
0.87 \\
0.09 \\
12.23 \\
10.36 \\
0.00 \\
2.28 \\
0.00 \\
0.21 \\
0.00 \\
0.00 \\
96.21 \\
9.55\end{array}$ & $\begin{array}{r}42 . \\
2 . \\
13 . \\
8 . \\
2 . \\
0 . \\
15 . \\
11 . \\
0 . \\
2 . \\
0 . \\
0 . \\
0 . \\
0 .\end{array}$ & $\begin{array}{r}42.05 \\
2.66 \\
12.98 \\
8.77 \\
3.74 \\
0.15 \\
14.20 \\
11.21 \\
0.03 \\
2.51 \\
0.08 \\
0.32 \\
0.11 \\
0.02 \\
98.82\end{array}$ & $\begin{array}{l}01 \\
60 \\
84 \\
57 \\
04 \\
04 \\
03 \\
29 \\
04 \\
11 \\
07 \\
08 \\
06 \\
02\end{array}$ \\
\hline $\begin{array}{l}\text { Ti } \\
\text { Al } \\
\text { Al } \\
\text { Fe3+ } \\
\text { Fe2t } \\
\mathrm{Mn} \\
\mathrm{Mg} \\
\mathrm{Ca} \\
\mathrm{Ba} \\
\mathrm{Ha} \\
\mathrm{Hi} \\
\mathrm{Cr} \\
\mathrm{K} \\
\mathrm{F} \\
\mathrm{Cl} \\
\text { tot }\end{array}$ & $\begin{array}{r}6.0547 \\
0.2570 \\
1.9453 \\
0.2391 \\
1.0199 \\
0.2726 \\
0.0230 \\
3.1726 \\
1.7065 \\
0.0000 \\
0.7180 \\
0.0000 \\
0.0079 \\
0.0492 \\
0.0769 \\
0.0000 \\
15.4658\end{array}$ & $\begin{array}{l}6.0001 \\
0.2593 \\
1.9999 \\
0.2788 \\
0.9859 \\
0.3600 \\
0.0204 \\
3.0900 \\
1.7259 \\
0.0011 \\
0.7182 \\
0.0000 \\
0.0022 \\
0.0489 \\
0.0494 \\
0.0000\end{array}$ & $\begin{array}{r}0.2415 \\
1.8878 \\
0.2210 \\
1.0658 \\
0.3411 \\
0.0217 \\
3.0978 \\
1.6837 \\
0.0022 \\
0.7080 \\
0.0000 \\
0.0045 \\
0.0471 \\
0.0090 \\
0.0024 \\
15.4344\end{array}$ & $\begin{array}{r}6.0123 \\
0.2380 \\
1.9877 \\
0.3465 \\
0.8720 \\
0.2664 \\
0.0120 \\
3.2258 \\
1.7687 \\
0.0033 \\
0.7265 \\
0.0000 \\
0.0180 \\
0.0471 \\
0.0000 \\
0.0000 \\
15.5244\end{array}$ & $\begin{array}{r}0.2425 \\
1.9513 \\
0.2453 \\
0.9932 \\
0.1316 \\
0.0119 \\
3.3309 \\
1.7384 \\
0.0000 \\
0.7318 \\
0.0000 \\
0.0223 \\
0.0413 \\
0.0624 \\
0.0000 \\
15.4893\end{array}$ & $\begin{array}{r}6.2 \\
0.3 \\
1.7 \\
0.1 \\
0.6 \\
1.0 \\
0.0 \\
2.7 \\
1.7 \\
0.0 \\
0.6 \\
0.0 \\
0.0 \\
0.0 \\
0.0 \\
0.0 \\
15.4\end{array}$ & $\begin{array}{l}0.2 \\
1.9 \\
0.2 \\
0.9 \\
0.3 \\
0.0 \\
3.2 \\
1.7 \\
0.0 \\
0.7 \\
0.0 \\
0.0 \\
0.0 \\
0.0 \\
0.0 \\
15.5\end{array}$ & $\begin{array}{r}6.0 \\
0.2 \\
1.9 \\
0.2 \\
0.9 \\
0.2 \\
0.0 \\
3.2 \\
1.7 \\
0.0 \\
0.7 \\
0.0 \\
0.0 \\
0.0 \\
0.0 \\
0.0 \\
15.5\end{array}$ & $\begin{array}{l}0 . \\
0 . \\
0 . \\
0 . \\
0 . \\
0 . \\
3 . \\
1 . \\
0 . \\
0 . \\
0 . \\
0 . \\
0 . \\
0 .\end{array}$ & $\begin{array}{l}5.7 \\
0.1 \\
1.7 \\
0.0 \\
0.5 \\
0.1 \\
0.0 \\
2.6 \\
1.6 \\
0.0 \\
0.6 \\
0.0 \\
0.0 \\
0.0 \\
0.0 \\
0.0\end{array}$ & $\begin{array}{r}6.0 \\
0.8 \\
1.8 \\
0.3 \\
0.8 \\
0.3 \\
0.0 \\
3.1 \\
1.7 \\
0.0 \\
0.7 \\
0.0 \\
0.0 \\
0.0 \\
0.0 \\
0.0 \\
15.4\end{array}$ & $\begin{array}{l}0 . \\
0 \\
0 \\
0 \\
3 . \\
1 \\
0 \\
0 \\
0 \\
0 \\
0 . \\
0 . \\
0 .\end{array}$ & \\
\hline$+K+K=T i$ & 0 & 0 & 1528 & 85 & & & & & & & & & \\
\hline
\end{tabular}




\section{APPENDIX VIII - Spinel compositions}

Plagioclase compositons were determined on the JEOL JXA-733 microprobe at Southern Methodist University using standard analytical stratagies and instrumental settings. 
Spurr Volcanic Complex spinel analyses

\begin{tabular}{|c|c|c|c|c|c|c|c|c|c|c|c|c|c|c|c|c|}
\hline $\begin{array}{l}\text { Strat\# } \\
\text { Field\# } \\
\text { Grain } \\
\text { Anal\# }\end{array}$ & $\begin{array}{r}\text { AMs-B07 } \\
85 \mathrm{cns} 43 \\
\text { sp1.015c } \\
284\end{array}$ & $\begin{array}{r}\text { AMs }-807 \\
85 \mathrm{cns} 43 \\
\text { sp2.015c } \\
285\end{array}$ & $\begin{array}{r}\text { AMS }-807 \\
85 \text { ens } 43 \\
\text { sp3.015c } \\
286\end{array}$ & $\begin{array}{r}\text { AMS }-807 \\
85 \mathrm{cns} 43 \\
\text { sp4.015m } \\
287\end{array}$ & $\begin{array}{r}\text { AMS }-B 07 \\
85 \mathrm{cns} 43 \\
\text { sp5.ol5r } \\
290\end{array}$ & $\begin{array}{r}\text { AMs-B07 } \\
85 \mathrm{cns} 43 \\
\text { sp6.015r } \\
288\end{array}$ & $\begin{array}{r}\text { AMs-B07 } \\
85 \text { cns43 } \\
\text { sp7.ol5r } \\
289\end{array}$ & $\begin{array}{r}\text { PCP- } 105 \\
85 c n s 50 \\
\text { P2.sp2. } \\
117\end{array}$ & $\begin{array}{r}P C P-A 05 \\
85 c n s 50 \\
\text { PS1-sp5 } \\
120\end{array}$ & $\begin{array}{r}P C P-A 05 \\
85 C n s 50 \\
\text { PS2. } 594 \\
121\end{array}$ & $\begin{array}{r}\text { cP-07 } \\
85 \mathrm{cns} 60 \\
\text { sp1.017c } \\
271\end{array}$ & $\begin{array}{r}\text { CP-07 } \\
85 \mathrm{cns} 60 \\
5 p 2 \\
273\end{array}$ & $\begin{array}{r}\text { CP- } 07 \\
85 \mathrm{cns} 60 \\
5 p^{3} \\
274\end{array}$ & $\begin{array}{r}c P-07 \\
85 \mathrm{cns} 60 \\
s p 4.016 \mathrm{c} \\
275\end{array}$ & $\begin{array}{r}s p-02 \\
s p-r s 2 \\
s p 1.012 \\
235\end{array}$ & $\begin{array}{r}\text { sP-02 } \\
\text { sp-rs2 } \\
\text { sp2.ol2 } \\
236\end{array}$ \\
\hline $\begin{array}{l}\text { wty } \\
\text { siO2 } \\
\text { TiO2 } \\
\text { Al203 } \\
\text { FezO3 } \\
\text { Feo } \\
\text { MnO } \\
\text { MgO } \\
\text { CaO } \\
\text { Cr203 } \\
\text { sUi } \\
\text { FeO meas. }\end{array}$ & $\begin{array}{r}0.06 \\
0.93 \\
25.38 \\
17.41 \\
14.04 \\
0.20 \\
11.56 \\
0.02 \\
31.00 \\
100.61 \\
29.71\end{array}$ & $\begin{array}{r}0.06 \\
0.84 \\
23.67 \\
17.89 \\
13.56 \\
0.25 \\
11.30 \\
0.01 \\
32.03 \\
99.61 \\
29.66\end{array}$ & $\begin{array}{r}0.06 \\
0.76 \\
24.44 \\
17.57 \\
13.73 \\
0.27 \\
11.08 \\
0.03 \\
30.21 \\
98.15 \\
29.54\end{array}$ & $\begin{array}{r}0.05 \\
0.61 \\
22.27 \\
17.58 \\
13.18 \\
0.27 \\
10.92 \\
0.01 \\
34.29 \\
99.18 \\
29.00\end{array}$ & $\begin{array}{r}0.05 \\
1.38 \\
12.00 \\
21.08 \\
18.81 \\
0.36 \\
6.03 \\
0.07 \\
40.05 \\
99.83 \\
37.78\end{array}$ & $\begin{array}{r}0.25 \\
0.80 \\
23.61 \\
17.11 \\
15.59 \\
0.29 \\
9.74 \\
0.03 \\
29.17 \\
96.58 \\
30.98\end{array}$ & $\begin{array}{r}0.07 \\
2.78 \\
8.61 \\
28.60 \\
22.34 \\
0.34 \\
4.77 \\
0.04 \\
30.16 \\
97.72 \\
48.08\end{array}$ & $\begin{array}{r}0.08 \\
20.55 \\
3.85 \\
23.33 \\
43.56 \\
0.35 \\
3.61 \\
0.02 \\
95.35 \\
64.55\end{array}$ & $\begin{array}{r}0.06 \\
0.31 \\
53.70 \\
9.34 \\
22.45 \\
0.23 \\
11.23 \\
0.05 \\
97.37 \\
30.85\end{array}$ & $\begin{array}{r}0.03 \\
0.59 \\
54.43 \\
7.29 \\
25.48 \\
0.19 \\
9.57 \\
0.04\end{array}$ & $\begin{array}{r}0.08 \\
3.16 \\
17.98 \\
24.21 \\
19.31 \\
0.34 \\
9.01 \\
0.02 \\
26.59 \\
100.70 \\
41.09\end{array}$ & $\begin{array}{r}0.10 \\
0.63 \\
21.58 \\
17.37 \\
13.94 \\
0.23 \\
10.50 \\
0.00 \\
35.89 \\
100.24 \\
29.57\end{array}$ & $\begin{array}{r}0.08 \\
0.63 \\
21.05 \\
17.67 \\
15.70 \\
0.29 \\
9.25 \\
0.02 \\
35.48 \\
100.16 \\
31.59\end{array}$ & $\begin{array}{r}0.07 \\
0.62 \\
22.10 \\
17.43 \\
12.68 \\
0.22 \\
11.23 \\
0.02 \\
34.04 \\
99.21 \\
28.36\end{array}$ & $\begin{array}{r}0.15 \\
1.33 \\
11.75 \\
48.24 \\
25.55 \\
0.24 \\
5.01 \\
0.02 \\
8.44 \\
100.73 \\
68.95\end{array}$ & $\begin{array}{r}0.09 \\
3.85 \\
7.95 \\
51.13 \\
29.16 \\
0.30 \\
3.88 \\
0.16 \\
3.47 \\
99.98 \\
75.16\end{array}$ \\
\hline $\begin{array}{l}\text { atoms } / 40 \\
\text { si } \\
\text { Ti } \\
\text { Al } \\
\text { fe3t } \\
\text { Fe2+ } \\
\text { Mn } \\
\text { Mg } \\
\text { Ca } \\
\text { Cr } \\
\text { total }\end{array}$ & $\begin{array}{l}0.0021 \\
0.0246 \\
1.05336 \\
0.4614 \\
0.4135 \\
0.0060 \\
0.6066 \\
0.0008 \\
0.4315 \\
3.0000\end{array}$ & $\begin{array}{l}0.0022 \\
0.0228 \\
1.0071 \\
0.4860 \\
0.4093 \\
0.0076 \\
0.6078 \\
0.0004 \\
0.4569 \\
3.0000\end{array}$ & $\begin{array}{l}0.0022 \\
0.0207 \\
1.0431 \\
0.4787 \\
0.4157 \\
0.0083 \\
0.5978 \\
0.0012 \\
0.4323 \\
3.0000\end{array}$ & $\begin{array}{l}0.0018 \\
0.0170 \\
0.9714 \\
0.4894 \\
0.4080 \\
0.0085 \\
0.6021 \\
0.0004 \\
0.5015 \\
3.0000\end{array}$ & $\begin{array}{l}0.0021 \\
0.0432 \\
0.5892 \\
0.6607 \\
0.6554 \\
0.0127 \\
0.3743 \\
0.0031 \\
0.6594 \\
3.0001\end{array}$ & $\begin{array}{l}0.0093 \\
0.0223 \\
1.0319 \\
0.4774 \\
0.4832 \\
0.0091 \\
0.5382 \\
0.0012 \\
0.4275 \\
3.0000\end{array}$ & $\begin{array}{l}0.0029 \\
0.0873 \\
0.4236 \\
0.8983 \\
0.7799 \\
0.0120 \\
0.2967 \\
0.0018 \\
0.4975 \\
3.0001\end{array}$ & $\begin{array}{l}0.0030 \\
0.5613 \\
0.1707 \\
0.6605 \\
1.3702 \\
0.0112 \\
0.2024 \\
0.0008 \\
0.0000 \\
3.0001\end{array}$ & $\begin{array}{l}0.0017 \\
0.0066 \\
1.7852 \\
0.1982 \\
0.5294 \\
0.0055 \\
0.4719 \\
0.0015 \\
0.0000 \\
3.0000\end{array}$ & $\begin{array}{l}0.0008 \\
0.0126 \\
1.8177 \\
0.1554 \\
0.6037 \\
0.0046 \\
0.4040 \\
0.0012 \\
0.0000 \\
3.0000\end{array}$ & $\begin{array}{l}0.0029 \\
0.0867 \\
0.7730 \\
0.0644 \\
0.5888 \\
0.0105 \\
0.4897 \\
0.0008 \\
0.3833 \\
3.0001\end{array}$ & $\begin{array}{l}0.0037 \\
0.0176 \\
0.9449 \\
0.4855 \\
0.4330 \\
0.0072 \\
0.5812 \\
0.0000 \\
0.5269 \\
3.0000\end{array}$ & $\begin{array}{l}0.0030 \\
0.0178 \\
0.9322 \\
0.4993 \\
0.4931 \\
0.0092 \\
0.5178 \\
0.0008 \\
0.5268 \\
3.0000\end{array}$ & $\begin{array}{l}0.0026 \\
0.0173 \\
0.9647 \\
0.4856 \\
0.3926 \\
0.0069 \\
0.6197 \\
0.0008 \\
0.5099 \\
3.0000\end{array}$ & $\begin{array}{l}0.0054 \\
0.0359 \\
0.4965 \\
1.3012 \\
0.7659 \\
0.0073 \\
0.2676 \\
0.0008 \\
0.1196 \\
3.0001\end{array}$ & $\begin{array}{l}0.0 \\
0.1 \\
0.3 \\
1.3 \\
0.8 \\
0.0 \\
0.8 \\
0.0 \\
0.0 \\
3 .\end{array}$ \\
\hline $\begin{array}{l}\text { mol } \times \text { usp } \\
\text { Mg\# } \\
\text { Cr/Cr+Al } \\
\text { YFe } \\
\text { rCr } \\
\text { YAl }\end{array}$ & $\begin{array}{l}9.38 \\
59.5 \\
29.1 \\
23.7 \\
22.2 \\
54.1\end{array}$ & $\begin{array}{l}8.35 \\
59.8 \\
31.2 \\
24.9 \\
23.4 \\
51.6\end{array}$ & $\begin{array}{l}7.7 \\
59 . \\
29 . \\
24 . \\
22 . \\
53 .\end{array}$ & $\begin{array}{l}6.3 \\
59.8 \\
34.8 \\
24.8 \\
25.8 \\
49.8\end{array}$ & $\begin{array}{r}11.38 \\
36.4 \\
52.8 \\
34.6 \\
34.5 \\
30.9\end{array}$ & $\begin{array}{l}8.32 \\
52.7 \\
29.3 \\
24.6 \\
22.1 \\
53.3\end{array}$ & $\begin{array}{r}16.13 \\
27.6 \\
54.0 \\
49.4 \\
27.3 \\
23.3\end{array}$ & $\begin{array}{r}63.71 \\
12.9 \\
0.0 \\
79.5 \\
0.0 \\
20.5\end{array}$ & $\begin{array}{r}5.75 \\
47.1 \\
0.0 \\
10.0 \\
0.0 \\
90.0\end{array}$ & $\begin{array}{r}12.67 \\
40.1 \\
0.0 \\
7.9 \\
0.0 \\
92.1\end{array}$ & $\begin{array}{r}20.41 \\
45.4 \\
33.1 \\
36.5 \\
21.1 \\
42.5\end{array}$ & $\begin{array}{l}6 . \\
57 \\
35 \\
24 \\
26 \\
48\end{array}$ & $\begin{array}{l}6.48 \\
51.2 \\
36.1 \\
25.5 \\
26.9 \\
47.6\end{array}$ & .2 & $\begin{array}{r}25.9 \\
19.4 \\
67.9 \\
6.2 \\
25.9\end{array}$ & 78 \\
\hline
\end{tabular}


APPENDIX IX

THERMAL WATER AND FUMAROLE GAB CHEMISTRY, MOUNT SPURR, ALASKA

by

Roman J. Motyka ${ }^{1}$ and Christopher J. Nye ${ }^{2}$

${ }^{1}$ Alaska Division of Geological and Geophysical Surveys, 400 Willoughby Center, 3rd floor, Juneau, Alaska 99801.

${ }^{2}$ Geophysical Institute, University of Alaska, Fairbanks, Alaska, 99775 
INTRODUCTION

Fumarolic gas samples were collected in August 1982 during a reconnaissance investigation of the 1953 volcanic crater located at an elevation of $7700 \mathrm{ft}$, just below Crater Peak (see fig. 2, Nye, this report). This crater was the source of the 1953 Mount spurr ash eruption (Juhle and Coulter, 1955). The fumarole field consisted of a series of diffuse to moderately pressurized boiling point fumarolic vents that issued from a mound of volcanic ash perched above the crater lake. Warm vapor was visibly rising from the $100 \mathrm{~m}$ diameter milky-blue lake. Steep ashy crater walls made descent down onto the lake too hazardous and no lake water samples were collected. By the summer of 1985 fumarolic activity along the rim of the crater lake had decreased to diffuse emissions, and a large (several meters in diameter) fumarolic vent had formed in the talus on the north slope of the crater lake.

A kilometer-long zone of warm springs was discovered in 1985 in the bottom of the valley immediately south of crater Peak, at an elevation of $2000 \mathrm{ft}$ (see fig. 2, Nye, this report). We sampled $40 \mathrm{C}$ water issuing from a seep in the eastern wall of the canyon. Most of the springs are in the valley bottom and are extensively diluted with stream water. Total warm water flow for the entire valley bottom is probably on the order of a thousand liters per minute.

\section{METHODS}

The procedures followed for collection and treatment of water samples for geochemical analyses and for field determination of $\mathrm{pH}$ and $\mathrm{HCO}_{3}$ and $\mathrm{H}_{2} \mathrm{~S}$ concentration are described in Presser and Barnes (1974). Major, minor and trace cation concentrations were determined using a Model 4000 Perkin-Elmer atomic absorption spectrometer with HGA 400 graphite furnace following standard procedures outlined in skougstad and others (1979) and in the 
Perkin-Elmer reference manual. Sulfates, bromide, and iodide were determined using a Dionex model 2010 i ion chromatograph. Fluorides were determined by specific ion electrode; $\mathrm{Cl}$ by Mohr titration; and boron by the carminic acid method. silica concentrations were determined by the molybdate blue method.

Gases were collected using a funnel emplaced over the fumarolic vent and connected to the collecting flask with tygon tubing. Gases were collected in evacuated sodium-hydroxide charged flasks for determination of gas composition and in evacuated uncharged flasks made from helium impermeable corning 1720 glass for determination of ${ }^{3} \mathrm{He} /{ }^{4} \mathrm{He}$ ratios and $\operatorname{del}{ }^{13} \mathrm{C}-\mathrm{CO}_{2}$. Head-space gases in the sodium-hydroxide charged flasks $\left(\mathrm{H}_{2}, \mathrm{CH}_{4}\right.$, $\mathrm{O}_{2}, \mathrm{~N}_{2}$, and $\mathrm{Ar}$ ) were analyzed on a dual-column gas chromatograph using helium and nitrogen carrier gases. The total moles of gas not absorbed in the sodium-hydroxide solution were determined by measuring the gas pressure and head space volume. $\mathrm{CO}_{2}$ and $\mathrm{H}_{2} \mathrm{~S}$ molar concentrations in the solution were determined by titration and by gravimetric means respectively, following procedures outlined in Sheppard and Giggenbach (1985). Adjustments were made for head space gases dissolved in the solution using Henry's Law. Moles of each constituent collected were then determined and the mole percent of each constituent calculated.

Stable isotope compositions of water samples were analyzed under contract at the stable Isotope Laboratory, Southern Methodist University. ${ }^{13} \mathrm{c} /{ }^{12} \mathrm{C}$ ratios in $\mathrm{CO}_{2}$ were determined at U.S. Geological Survey, Menlo Park. ${ }^{3} \mathrm{He} /{ }^{4} \mathrm{He}$ ratios were analyzed by $R$. Poreda at the stable Isotope Laboratory, Scripps Institution of oceanography.

\section{GAS CHEMISTRY}

The fumarolic gases are water rich (97.9 \& steam) with the residual gases consisting almost entirely of $\mathrm{CO}_{2}$ with minor to trace amounts of $\mathrm{N}_{2}, \mathrm{Ar}, \mathrm{H}_{2} \mathrm{~S}, \mathrm{H}_{2}$, and $\mathrm{CH}_{4}$ (table 1), a composition typical of boiling-point fumarolic vents associated 
with volcanos elsewhere in the Aleutian arc (Motyka, 1983). The fumarolic vents at the active crater are probably associated with the degassing of residual magma associated with the 1953 eruption. Much of the steam is probably meteoric water that has infiltrated into the zone of elevated temperatures below the active crater. The $\mathrm{N}_{2} / \mathrm{Ar}$ ratio is nearly that of air indicating that the source of most of the $\mathrm{N}_{2}$ and $\mathrm{Ar}$ in the fumarolic gases is atmospheric contamination with oxygen removed in oxidation reactions. The remaining constituents are probably derived either from the magmatic source or from high-temperature interactions with country rocks.

The helium isotope ratio of $R / R_{a}=6.6$ (table 1) 1ies within the range of values $(5-8)$ found at other Aleutian arc volcanos (Poreda, 1983; Motyka, 1983), and is indicative of the magmatic influence on the crater Peak hydrothermal system. The del ${ }^{13} \mathrm{C}-\mathrm{CO}_{2}$ values of -12 and -14 per mil are significantly lighter than mantle-derived $\mathrm{CO}_{2}$, which is estimated to range from -4 to -9 , but lie at the upper end of the range of values estimated for carbon dioxide derived from organic-sedimentary sources (Truesdell and Hulston, 1980). The light del ${ }^{13} \mathrm{C}-\mathrm{CO}_{2}$ values therefore suggests an organic sedimentary origin for some of the $\mathrm{CO}_{2}$. The presence of $\mathrm{CH}_{4}$ in the fumarolic gases also suggests a thermogenic sedimentary origin for some of the carbon. The West Foreland Formation of mid-Tertairy age is exposed east and south of crater Peak and probably underlies crater Peak (Nye, this report). The formation is non-marine but contains abundant plant fossils and scattered coal seams (Calderwood and Fackler, 1972), which are likely sources of thermogenically generated organicsedimentary carbon gases.

D'Amore and Panichi (1980) have proposed a gas geothermometer for estimating geothermal reservoir temperatures based on the proportions of $\mathrm{CO}_{2}, \mathrm{H}_{2} \mathrm{~S}, \mathrm{H}_{2}$, and $\mathrm{CH}_{4}$, in fumarolic gases. Application of this geothermometer to the gas analysis of the Crater Peak fumarole for assumed $\mathrm{CO}_{2}$ partial pressures of 0.5 and 
1 bar suggests the source region for equilibration of these gases has a temperature on the order of $200 \mathrm{C}$ (table 1).

\section{WATER CHEMISTRY}

The thermal water sampled near the base of crater Peak is slightly acidic, relatively low in $\mathrm{Cl}^{-}$but rich in $\mathrm{HCO}_{3}^{-}$and $\mathrm{SO}_{4}=$, and has a relatively high concentration of $\mathrm{Mg}^{++}$(table 2 ). The setting and chemistry of the crater Peak thermal spring water is very similar to Mother Goose hot springs located on the Alaska Peninsula (Motyka and others, 1981). Both sites are typified by large rates of discharge of $\mathrm{HCO}_{3}{ }^{-}-\mathrm{SO}_{4}=\mathrm{rich}, \mathrm{Cl}^{-}$poor thermal spring water and are located at or near the base of a volcanic peak with an active fumarole field. The high concentrations of $\mathrm{HCO}_{3}{ }^{-}$and $\mathrm{SO}_{4}=$ suggest the influence of volcanic gases on the thermal waters. Condensation of steam and interaction of fumarolic gases with cold ground waters would produce an acidic moderate- to low-enthalpy thermal water. The cation constituents and silica present in the water could have been largely derived through acid breakdown of country rock which would in turn buffer the water to its near-neutral but slightly acidic pH. The relatively large concentration of $\mathrm{Mg}^{++}$present in the water is also indicative of a moderate- to low-enthalpy water because $\mathrm{Mg}^{++}$ is usually removed from high temperature waters through hydrothermal reactions (Fournier, 1981).

The source of the $\mathrm{Cl}^{-}$and $\mathrm{Br}^{-}$present in the water is problematic. Volcanic rocks normally contain these anions in only minor to trace amounts. Marine sediments do not appear to underlie crater Peak and in any event the $\mathrm{Br} / \mathrm{Cl}$ ratio in the thermal water $(0.0020)$ is substantially lower than in seawater $(0.0036)$. The chloride and bromide could have been derived from connate terrestrial waters in which these anions have become concentrated. Alternately, the $\mathrm{Cl}^{-}$and $\mathrm{Br}^{-}$could have been derived from a deep reservoir of cl-rich hot-water or possibly as gases emanating directly from the magmatic source. 
The stable isotope composition of the thermal water and two local stream waters are plotted on fig. A1. Sample $S_{1}$ was obtained from a stream adjacent to the area of thermal spring activity. $s_{2}$ was collected from a stream of run-off waters on top of Kidazgeni Glacier at an elevation of $2600 \mathrm{ft}$ (see fig. 2 , Nye, this report). The meteoric water line of craig (1961) is also plotted for comparison. All three samples plot to the right of the craig meteoric water line and both of the sampled local stream waters are substantially lighter than the thermal water. Although the data are insufficient to constrain the origins of the thermal water isotopic composition some observations can nevertheless be made.

The source of water charging the majority of hydrothermal systems is considered to meteoric water (Truesdall and Hulston, 1980). If this is also the case at crater Peak then the sources of differences in isotopic compositions between $s_{1}, s_{2}$, and the thermal waters need to be examined. The temperature dependency of isotopic composition in precipitation produces seasonal variations (winter precipitation is depleted in heavy isotopes with respect to summer precipitation) and altitude variations (the heavy isotope content of precipitation decreases with increasing elevation) (Panichi and Gonfianti, 1978). The surface streams that were sampled derive most of their water as run-off from higher elevations. Much of this run-off is probably meltwater from winter snowfall. These sources of stream water would account for the apparent depletion of heavy isotopes.

If meteoric water is a substantial component of the crater Peak thermal water than the meteoric water charging the groundwater system would have to be derived from either 1) precipitation falling at substantially lower elevations than either site $s_{1}$ or $s_{2}$ or 2 ) from summer precipitation or both. An alternative model is that the thermal water is a mixture of meteoric waters similar to $s_{1}$ and $s_{2}$ and waters having $a$ 
substantially heavier isotopic composition. The source of this component of heavier water could be a thermal water from a deep reservoir or possibly connate formation water.

Table 3 gives the results of applying commonly used thermal water geothermometers (Fournier, 1981) and the $\mathrm{K}^{+}-\mathrm{Mg}^{++}$ geothermometer proposed by Giggenbach and others (1983). However, because of the uncertainty in mixing relationships and the probability of disequilibrium reactions caused by acid gases, we urge caution be used in interpreting these chemical geothermometers in estimating temperatures of any deep reservoir. We do wish to point out that thermal spring waters with somewhat similar chemical characteristics have been found to be indicative of shallow vapor-dominated zones overlying boiling cl-rich hotwater reservoirs In particular, $\mathrm{HCO}_{3}{ }^{-}-\mathrm{SO}_{4}=$ rich, $\mathrm{Cl}^{-}$poor thermal springs were found at the Makushin geothermal area on Unalaska Island. The area was subsequently drilled and found to house a substantial Cl-rich, hot-water reservoir (Motyka and others, 1983; Motyka and others, 1985). However, given the results of the accompanying study on the petrology and geochemistry of the Mount Spurr Volcanic Complex which found no evidence for a geothermally significant large-scale, shallowlying magma system (Nye, this report), the crater Peak thermal waters are more likely associated with localized residual degassing of magma underlying crater Peak.

\section{CONCLUSIONS}

Fumaroles surrounding the active crater on crater Peak are probably associated with the cooling and degassing of magma associated with the 1953 eruption. Infiltration of meteoric waters into the hot subsurface region overlying the magma is probably the source of much of the steam being emitted from the fumaroles. Acid gases and steam escaping from this hot subsurface region form a shallow vapor-dominated zone and interact with shallow ground waters and country rocks to produce 
the thermal springs in valley south of crater Peak. These spring waters may also contain either a minor component of deep reservoir cl-rich thermal waters or connate formation waters. Because the thermal spring water appears to be a mixture from diverse sources, we consider interpretation of the results of the thermal water geothermometers to be problematic. Gas geothermometry suggests that the equilibration temperature for fumarolic gases is on the order of $200 \mathrm{c}$. 
REFERENCES CITED

Calderwood, K.W, and Fackler, W.C., 1972, Proposed stratigraphic nomenclature for Kenai Group, cook Inlet Basin, Alaska: American Association of Petroleum Geologists Bulletin, v. 56, p. 739-754.

Craig, Harmon, 1961, Isotopic variations in meteoric waters, Science, v. 133, p. 1702 .

D'Amore, Franco, and Panichi, Costanzo, 1980, Evaluation of deep temperatures of hydrothermal systems by a new gas geothermometer: Geochimica et Cosmochimica Acta, v. 44 , p. 549-556.

Fournier, R.O., 1981, Application of water chemistry to geothermal exploration and reservoir engineering, in Ryback, I., and Muffler, L.P.J., eds., Geothermal systems: Principles and case histories: New York, Wiley and Sons, p. 109-144.

Giggenbach, W.F., Gonfiantini R., Jangi, B.L., and Truesdell, A.H., 1983, Isotopic and chemical composition of Parbati Valley geothermal discharges, Northwest Himalaya, India: Geothermics v. 12, p. 199-222.

Juhle, W, and Coulter, H, 1955, The Mt. Spurr eruption, July 9, 1953: Transactions, American Geophysical Union, v. $36, p$. 199-202.

Motyka, R.J., Moorman, M.A., and Liss, S.A., 1981, Assessment of thermal spring sites, Aleutian Arc, Atka Island to Becharof Lake--Preliminary results and evaluation: Alaska Division of Geological and Geophysical Surveys, open File Report AOF-144, $173 \mathrm{p}$.

Motyka, R.J., 1983, High-temperature hydrothermal resources in the Aleutian arc: 1982 Alaska Geological Society symposium on Western Alaska Geology and Resource Potential, Journal of the Alaska Geological Society, v. 3. p. 87-99.

Motyka, R.J., Moorman, M.A., and Poreda, R.J., 1983, Progress report - thermal fluid investigations of the Makushin geothermal area: Alaska Division of Geological and Geophysical surveys Report of Investigations 83-15, $48 \mathrm{p}$.

Motyka, R.J., Queen, L.D., Janik, C.J., Sheppard, D.S., Poreda, R.J., and Liss, S.A., 1985, Fluid geochemistry and fluidmineral equilibria in test wells and thermal gradient holes at the Makushin Geothermal Area, Unalaska Island, Alaska: Alaska Division of Geological and Geophysical Surveys, PDF $86-59,115 \mathrm{pp}$. 
Panichi, Costanzo, and Gonfiantini, R., 1978, Environmental isotopes in geothermal studies: Geothermics, v. 6, p. 143161.

Poreda, R.J., 1983, Helium, neon, water and carbon in volcanic rocks and gases: University of California, San Diego, Ph. D. thesis, $215 \mathrm{p}$.

Presser, T.S., and Barnes, Ivan, 1974, Special techniques for determining chemical properties of geothermal waters, U. S. Geological Survey Water-Resources Investigation Report 2274, $11 \mathrm{p}$.

Sheppard, D.S., and Giggenbach, W.F., 1985, Methods for the analysis of geothermal and volcanic waters and gases: Chemistry Division, Department of Scientific and Industrial Research, New Zealand, Report No. C.D. 2364,78 pp.

Skougstad, M.W., Fishman, M.J., Friedman, M.J., Erdmann, D.E., and Duncan, s.s. (eds.), 1979, Methods for determination of inorganic substances in water and fluvial sediments: U.S. Geological Survey Techniques of Water - Resources Investigations, book 5 , chapterA1, 626p.

Truesdell, A.H., and Hulston, J.R., 1980, Isotopic evidence on environments of geothermal systems: in Handbook of Environmental Isotope Geochemistry: Elsevier, p. 1979-219. 
Table 1. Analysis of gases from fumarole located on rim of active crater, Mt. Spurr, Alaska.

$$
\begin{array}{cc}
\text { Date sampled } & 8-04-82 \\
\text { Sampling } T, C & 94 \\
\text { Steam, mole per cent } & 97.87
\end{array}
$$

Composition of Residual Gases, mole per cent:

$\begin{array}{rc}\mathrm{CO}_{2} & 95.6 \\ \mathrm{H}_{2} \mathrm{~S} & 0.78 \\ \mathrm{H}_{2} & 0.25 \\ \mathrm{CH}_{4} & 0.03 \\ \mathrm{~N}_{2} & 3.28 \\ \mathrm{Ar} & 0.044 \\ \mathrm{~N}_{2} / \mathrm{Ar} & 75 \\ \mathrm{C} / \mathrm{S} & 123\end{array}$

$$
\begin{array}{cc}
\operatorname{del}{ }^{13} \mathrm{C}-\mathrm{CO}_{2}, \text { per mil }{ }^{\mathrm{a}} & -14.2,-12.3 \\
{ }^{3} \mathrm{He} /{ }^{4} \mathrm{He}, \mathrm{R} / \mathrm{R}_{\mathrm{a}}{ }^{\mathrm{b}} & 6.6
\end{array}
$$

Gas Geothermometer of D'Amore and Panichi (1980):

$$
\begin{array}{ll}
T, C\left(\mathrm{PCO}_{2}=1.0 \text { bar }\right) & 215 \\
T, C\left(\mathrm{PCO}_{2}=0.5 \text { bar }\right) & 195
\end{array}
$$

a) Value with respect to PDB. Analyses performed at U.S. Geological Survey, Menlo Park, CA.

b) Ratio of ${ }^{3} \mathrm{He} /{ }^{4} \mathrm{He}$ in sample over that in air. R. Poreda, Isotope Laboratory, Scripps Institution of Oceanography, analyst. 
Table 2. Chemical analyses of waters collected from Mt Spurr hot springs, $1985^{\mathrm{a}}$. Concentrations in $\mathrm{mg} / 1$ unless otherwise specified.

\begin{tabular}{|c|c|}
\hline Sample & spurr-85 \\
\hline \multicolumn{2}{|l|}{ Cations } \\
\hline $\begin{array}{r}\mathrm{Na} \\
\mathrm{K}\end{array}$ & $\begin{array}{r}266 \\
75\end{array}$ \\
\hline $\mathbf{c a}$ & 95 \\
\hline Mg & 99 \\
\hline Li & 0.42 \\
\hline sr & 0.68 \\
\hline Cs & 0.04 \\
\hline \multirow{2}{*}{\multicolumn{2}{|c|}{$\underset{\text { Anions }}{\mathrm{NH}_{4}}$}} \\
\hline & \\
\hline $\mathrm{HCO}_{3}{ }^{\mathrm{b}}$ & 622 \\
\hline${ }^{\mathrm{SO}_{4}}$ & $\begin{array}{l}477 \\
1.0\end{array}$ \\
\hline cl & 254 \\
\hline $\mathrm{Br}$ & 0.5 \\
\hline I & 0.1 \\
\hline Bayance oc & -3.4 \\
\hline \multirow{3}{*}{$\underset{\mathrm{H}_{2} \mathrm{~S}_{\mathrm{B}}^{\mathrm{SiO}}}{\mathrm{SiO}}$} & 125 \\
\hline & 0.1 \\
\hline & 7.7 \\
\hline Al & nd \\
\hline As & 0.021 \\
\hline $\mathrm{Fe}$ & $<0.1$ \\
\hline TDS (calc.) & 1708 \\
\hline$T, \quad C_{b}$ & 40.2 \\
\hline del ${ }^{18^{H}}{ }_{d}^{d}$ & $\begin{array}{r}6.4 \\
-16.7\end{array}$ \\
\hline deID & -138 \\
\hline Sampled & $8-03-85$ \\
\hline
\end{tabular}

a) Alaska Division of Geological and Geophysical surveys, Fairbanks, M.A. Moorman, S.A. Liss and R.J. Motyka, analysts. b) Determined in the field.

c) Computed from $\frac{1}{2}(C-A) /(C+A)$ where $C$ and $A$ are the total cations and anions in milliequivalents/liter, respectively. d) Values in per mil with respect to standard mean ocean water (SMOW). For comparison, del 180 and deld values for a nearby cold stream are -19.9 and -155 ; values for a supra-glacial stream are -18.1 and -146. Analyses performed at the Stable Isotope Laboratory, Southern Methodist University. 
Table 3. Geothermometry of Mount Spurr hot springs. Temperatures in degrees celsius.

$\begin{array}{lr}\text { Quartz Conductive } & 150 \\ \text { Chalcedony } & 125 \\ \text { Amorphous } \mathrm{SiO}_{2} & 29 \\ \mathrm{Na}-\mathrm{K} & 325 \\ \mathrm{Na}-\mathrm{K}-\mathrm{Ca}(4 / 3) & 155 \\ \mathrm{Na}-\mathrm{K}-\mathrm{Ca}(1 / 3) & 237 \\ \mathrm{Na}-\mathrm{K}-\mathrm{Ca}, \mathrm{Mg} \text { corrected } & 17 \\ \mathrm{~K}-\mathrm{Mg} & 88\end{array}$




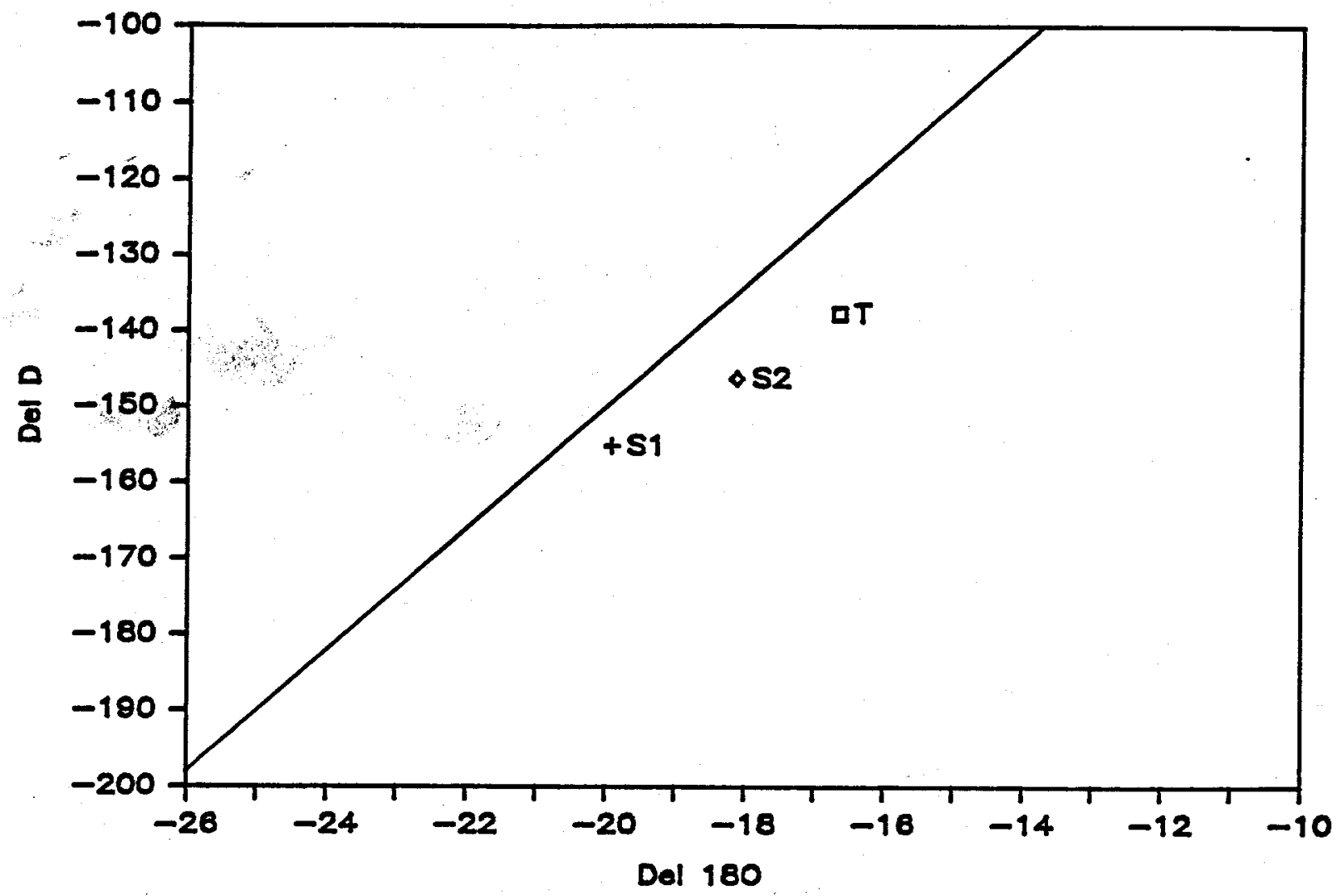

Figure Al. Stable isotope compositions of waters fromcrater Peak, Mount Spurr. $S_{1}$ and $S_{2}$ are stream waters. $T$ is a thermal spring water located near the base of Crater Peak. 